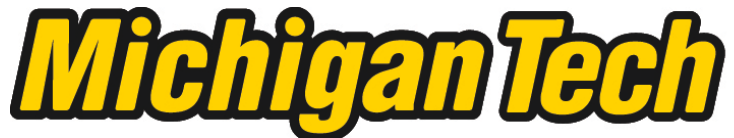 \\ Michigan Technological University Create the Future Digital Commons @ Michigan Tech
}

Effects of management on native and exotic plant communities in Pictured Rocks National Lakeshore in the Upper Peninsula of Michigan

Michelle Elise Latsch

Michigan Technological University

Follow this and additional works at: https://digitalcommons.mtu.edu/etds

Part of the Forest Sciences Commons

Copyright 2011 Michelle Elise Latsch

\section{Recommended Citation}

Latsch, Michelle Elise, "Effects of management on native and exotic plant communities in Pictured Rocks National Lakeshore in the Upper Peninsula of Michigan", Dissertation, Michigan Technological University, 2011.

https://doi.org/10.37099/mtu.dc.etds/129

Follow this and additional works at: https://digitalcommons.mtu.edu/etds

8 Part of the Forest Sciences Commons 


\title{
EFFECTS OF MANAGEMENT ON NATIVE AND EXOTIC PLANT COMMUNITIES IN PICTURED ROCKS NATIONAL LAKESHORE IN THE UPPER PENINSULA OF MICHIGAN
}

\author{
By \\ Michelle Elise Latsch \\ A DISSERTATION \\ Submitted in partial fulfillment of the requirements for the degree of \\ DOCTOR OF PHILOSOPHY \\ FOREST SCIENCE \\ MICHIGAN TECHNOLOGICAL UNIVERSITY \\ 2011
}

(C) 2011 Michelle Elise Latsch 
This dissertation, "Effects of Management on Native and Exotic Plant Communities in Pictured Rocks National Lakeshore in the Upper Peninsula of Michigan," is hereby approved in partial fulfillment of the requirements for the Degree of DOCTOR OF PHILOSOPHY IN FOREST SCIENCE.

School of Forest Resources and Environmental Science

Signatures:

Dissertation Advisor

Dr. Andrew J. Storer

Dean

Dr. Margaret R. Gale

Date 
To my parents,

for your perpetual encouragement, support, and help when it was needed most.

And to my brother,

who is always in my corner

and was the best field assistant on the planet. 


\section{TABLE OF CONTENTS}

List of Figures....................................................................................... vii

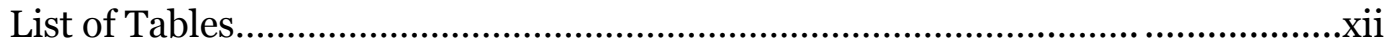

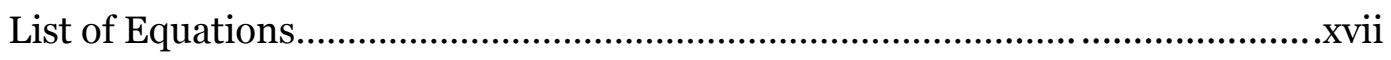

Acknowledgements. ............................................................................................

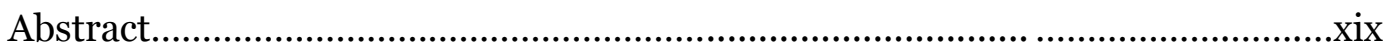

\section{Chapter 1. Introduction}

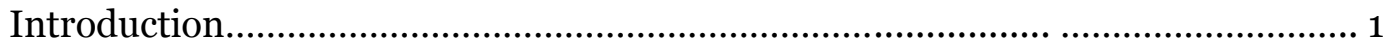

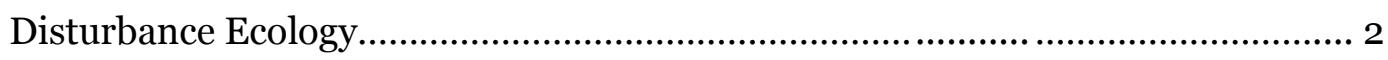

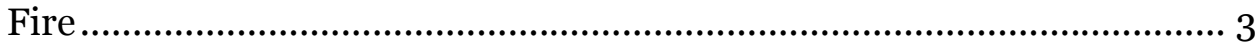

Introduced Species.......................................................................... 4

Disturbance and Plant Communities................................................................10

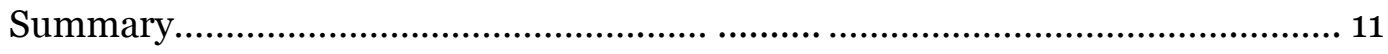

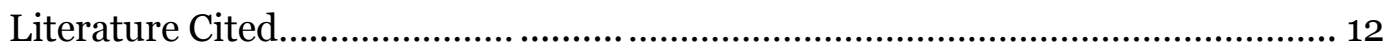

Chapter 2. History and Policy of the Management of Invasive Plants in Pictured Rocks National Lakeshore in Alger County, Michigan

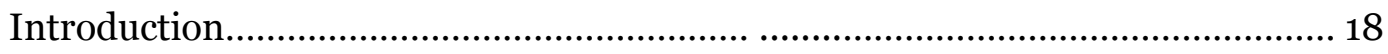

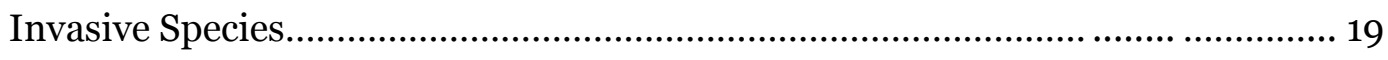

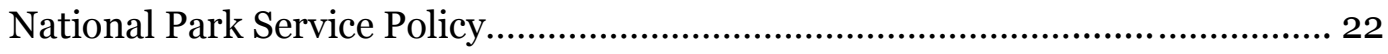

History of Pictured Rocks National Lakeshore................................................ 24

Invasive Species in Pictured Rocks National Lakeshore................................... 27

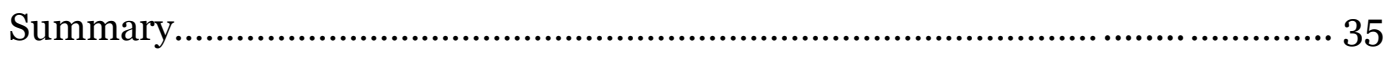

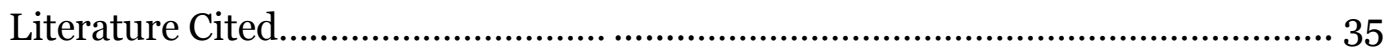

Chapter 3. Multi-Criteria Risk Assessment Models for Invasive Plants in Pictured Rocks National Lakeshore: Development, Validation, and Implementation

Abstract 


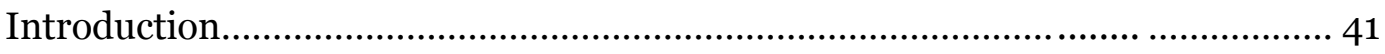

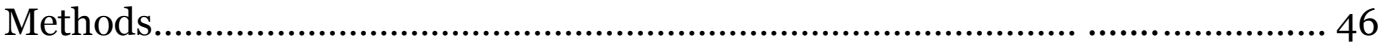

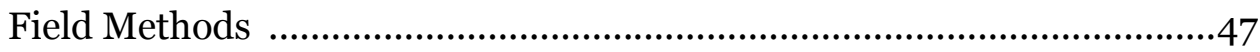

Model Development ..................................................................... 48

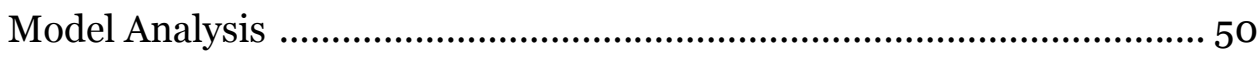

Risk Map Creation ........................................................................ 50

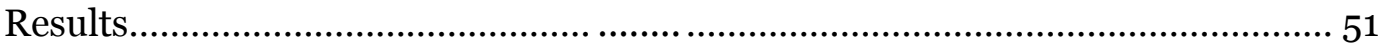

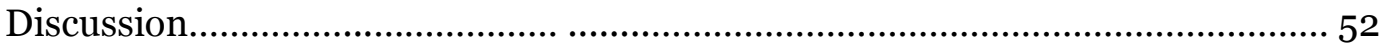

Continuing Research................................................................................ 57

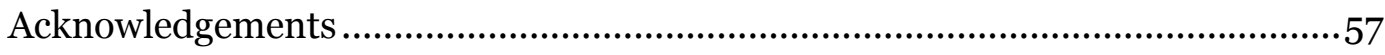

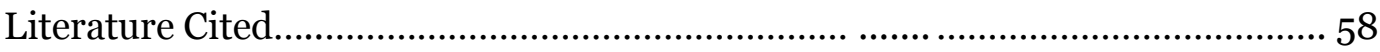

Chapter 4. Plant Community Compostion in Active Dune Areas Invaded by Spotted Knapweed (Centaurea maculosa Lam.) at Pictured Rocks National Lakeshore in Alger County, Michigan

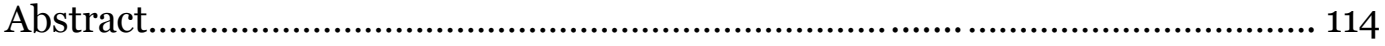

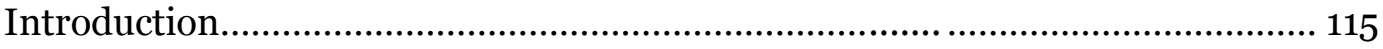

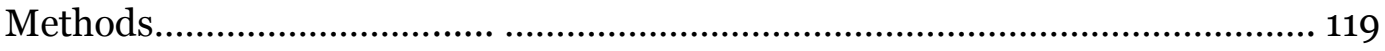

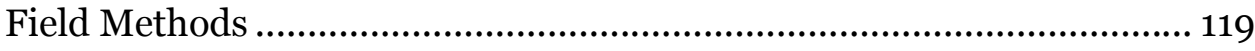

Statistical Methods ...........................................................................120

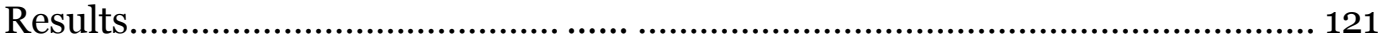

Species Composition ..................................................................... 121

Species Richness, Diversity, and Evenness ........................................122

Species Comparisons ....................................................................123

Linear Regression......................................................................... 127

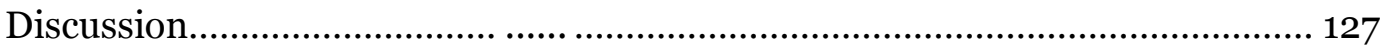

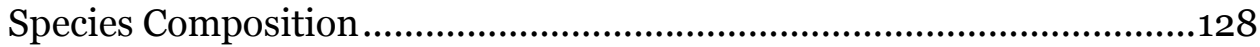

Summary Statistics: Richness, Diversity, and Evenness .......................129 
Species Comparisons ...................................................................130

Linear Regression ..................................................................... 131

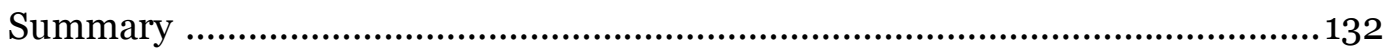

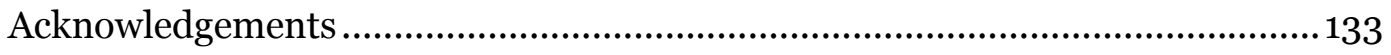

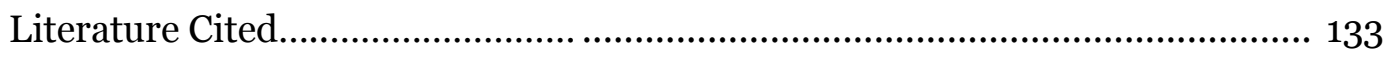

Chapter 5. Effects of Herbicide Application to Spotted Knapweed (Centaurea maculosa) on Native Dune Plant Communities in Pictured Rocks National Lakeshore, Alger County, Michigan

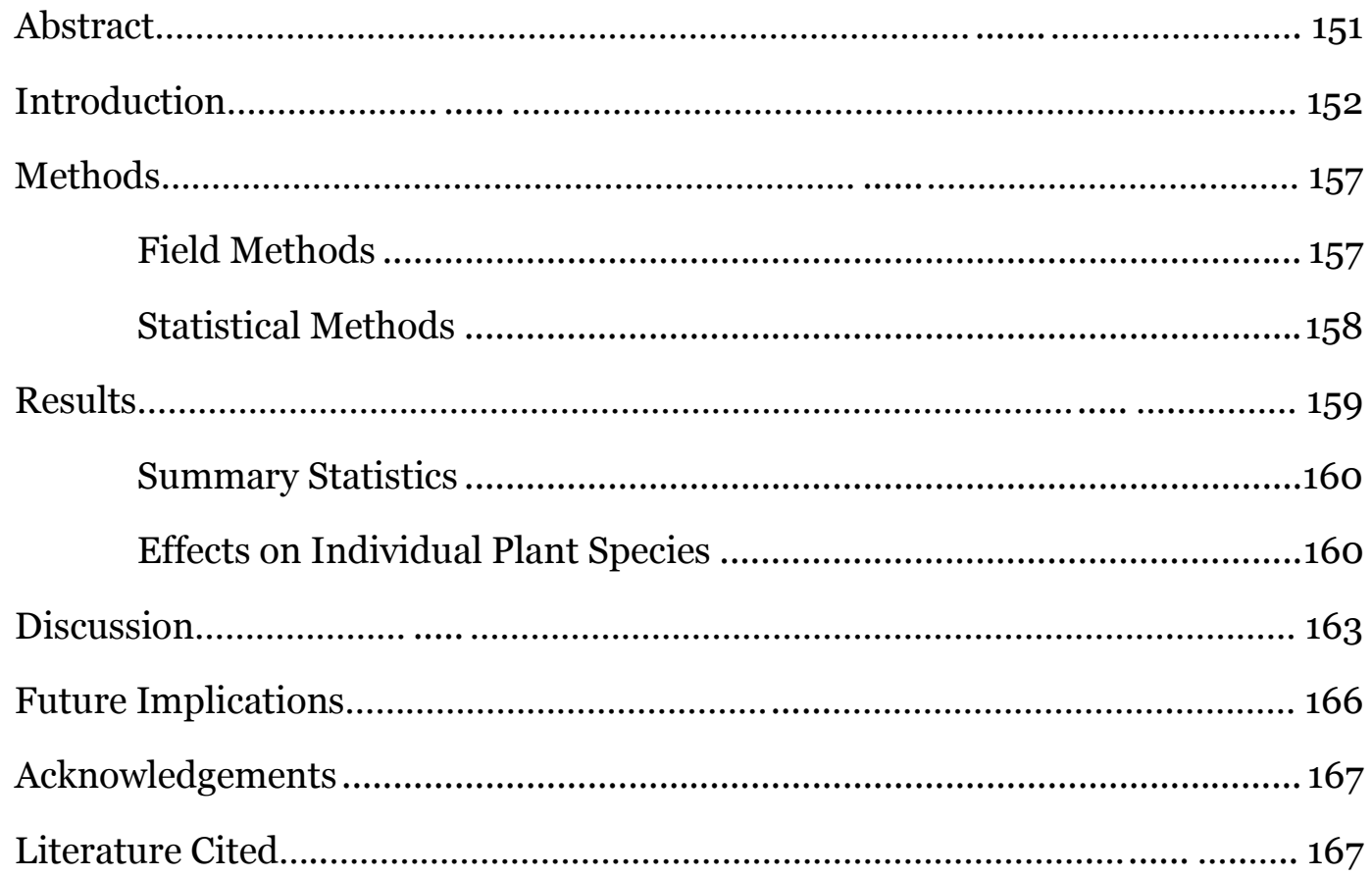

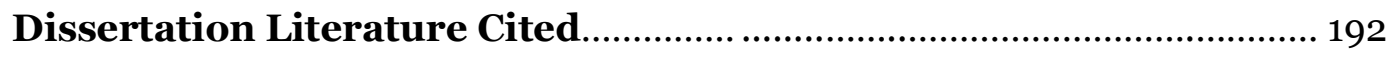




\section{LIST OF FIGURES}

Figure 1.1. Location of study sites in the Upper Peninsula of Michiga................. 17

Figure 3.1. 306 random sampling points within Pictured Rocks National Lakeshore, Alger County, Michigan sampled during the 2008 and 2009 field season...

Figure 3.2. Random points showing presence of invasive plants (represented by square points) as well as park GIS data for the eight invasive plants (represented by delineated shapes) for Pictured Rocks National Lakeshore, Alger County, Michigan. 75

Figure 3.3. Locations at which burdock was found at random points or mapped by the Exotic Plant Management Teams in Pictured Rocks National Lakeshore, Alger County, Michigan 76

Figure 3.4. Locations at which forget-me-not was found at random points or mapped by the Exotic Plant Management Teams in Pictured Rocks National Lakeshore, Alger County, Michigan 77

Figure 3.5. Locations at which red clover was found at random points or mapped by the Exotic Plant Management Teams in Pictured Rocks National Lakeshore, Alger County, Michigan 78

Figure 3.6. Locations at which spotted knapweed was found at random points or mapped by the Exotic Plant Management Teams in Pictured Rocks National Lakeshore, Alger County, Michigan. 79

Figure 3.7. The risk of introduction, establishment, and spread of burdock in Pictured Rocks National Lakeshore, Alger County, Michigan 80

Figure 3.8. The risk of introduction, establishment, and spread of bishop's goutweed in Pictured Rocks National Lakeshore, Alger County, Michigan................ 81

Figure 3.9. The risk of introduction, establishment, and spread of forget-me-not in Pictured Rocks National Lakeshore, Alger County, Michigan. 82

Figure 3.10. The risk of introduction, establishment, and spread of garlic mustard in Pictured Rocks National Lakeshore, Alger County, Michigan.............. 83

Figure 3.11. The risk of introduction, establishment, and spread of periwinkle in Pictured Rocks National Lakeshore, Alger County, Michigan.

Figure 3.12. The risk of introduction, establishment, and spread of red clover in Pictured Rocks National Lakeshore, Alger County, Michigan 85 
Figure 3.13. The risk of introduction, establishment, and spread of spotted knapweed in Pictured Rocks National Lakeshore, Alger County, Michigan 86

Figure 3.14. The risk of introduction, establishment, and spread of sweet clover in Pictured Rocks National Lakeshore, Alger County, Michig. 87

Figure 3.15. Model layout for burdock. 89

Figure 3.16. Model layout for bishop's goutweed 90

Figure 3.17. Model layout for forget-me-not 91

Figure 3.18. Model layout for garlic mustard 92

Figure 3.19. Model layout for periwinkle 93

Figure 3.20. Model layout for red clover 94

Figure 3.21. Model layout for spotted knapweed. . .95

Figure 3.22. Model layout for sweet clover 96

Figure 3.23. Output map for introduction, establishment, and spread of burdock.. 97

Figure 3.24. Output map for introduction, establishment, and spread of bishop's goutweed 98

Figure 3.25. Output map for introduction, establishment, and spread of forget-me-not 99

Figure 3.26. Output map for introduction, establishment, and spread of garlic mustard 100

Figure 3.27. Output map for introduction, establishment, and spread of periwinkle 101

Figure 3.28. Output map for introduction, establishment, and spread of red clover 102

Figure 3.29. Output map for introduction, establishment, and spread of spotted knapweed 103

Figure 3.30. Output map for introduction, establishment, and spread of sweet clover . .104

Figure 3.31. Average risk of introduction of all species modeled for Pictured Rocks National Lakeshore. 105 
Figure 3.32. Average risk of establishment of all species modeled for Pictured Rocks National Lakeshore. 106

Figure 3.33. Average risk of spread of all species modeled for Pictured Rocks National Lakeshore 107

Figure 3.34. Maximum risk of introduction of all species modeled for Pictured Rocks National Lakeshore 108

Figure 3.35. Maximum risk of establishment of all species modeled for Pictured Rocks National Lakeshore. 109

Figure 3.36. Maximum risk of spread of all species modeled for Pictured Rocks National Lakeshore. 110

Figure 3.37. Average risk of introduction of the three most ecologically damaging species modeled for Pictured Rocks National Lakeshore. 111

Figure 3.38. Average risk of establishment of the three most ecologically damaging species modeled for Pictured Rocks National Lakeshore 112

Figure 3.39. Average risk of spread of the three most ecologically damaging species modeled for Pictured Rocks National Lakeshore 113

Figure 4.1. Location of Pictured Rocks National Lakeshore in Alger County in the Upper Peninsula of Michigan. Study site highlighted in red 140

Figure 4.2. General area of spotted knapweed invasion at the study site in the Grand Sable Dunes, Pictured Rocks National Lakeshore, Alger County, Michigan. Delineated in 2008 141

Figure 4.3. Locations of the nine study plots in the Grand Sable Dunes of Pictured Rocks National Lakeshore, Upper Michigan. "L" plots are in areas of low spotted knapweed abundance, " $\mathrm{H}$ " plots are established in areas of high spotted knapweed abundance, and "N" plots are those established in areas without spotted knapweed. Some of the plots do not appear rectangular due to topography. 142

Figure 4.4. Three by five grid layout of a single sampling plot for the study in the Grand Sable Dunes of Pictured Rocks National Lakeshore, Michigan. Gray areas indicate 2 meter buffer areas between subplots and around plots. Numbered squares are the layout of the sampling quadrats within each subplot.......143

Figure 4.5. Percent cover of dune and non-dune plant species in areas with varying densities of spotted knapweed in the Grand Sable Dunes of Pictured Rocks National Lakeshore in Upper Michigan, USA. Error bars represent standard error for the percent of dune species. Spotted knapweed is included in the data for nondune plants 
Figure 4.6. Percent cover of dune and non-dune plant species in areas with varying densities of spotted knapweed in the Grand Sable Dunes of Pictured Rocks National Lakeshore in Upper Michigan, USA. Error bars represent standard error for the percent of dune species. Spotted knapweed is not included in the data. 144

Figure 4.7. Number of individuals of dune and non-dune plant species in areas with varying densities of spotted knapweed in the Grand Sable Dunes of Pictured Rocks National Lakeshore in Upper Michigan, USA. Error bars represent standard error for the percent of dune species. Spotted knapweed is included in the data for non-dune plants 145

Figure 4.8. Number of individuals of dune and non-dune plant species in areas with varying densities of spotted knapweed in the Grand Sable Dunes of Pictured Rocks National Lakeshore in Upper Michigan, USA. Error bars represent standard error for the percent of dune species. Spotted knapweed is not included in the data. 145

Figure 4.9. Species richness of percent cover for each abundance level in areas with varying densities of spotted knapweed in the Grand Sable Dunes of Pictured Rocks National Lakeshore in Upper Michigan, USA. Horizontal lines above the bars show contrasts that were tested between individuals or groups of bars with associated p-values 146

Figure 4.10. Species diversity of percent cover for each abundance level in areas with varying densities of spotted knapweed in the Grand Sable Dunes of Pictured Rocks National Lakeshore in Upper Michigan, USA. Horizontal lines above the bars show contrasts that were tested between individuals or groups of bars with associated p-values 147

Figure 4.11. Species diversity of number of individuals for each abundance level in areas with varying densities of spotted knapweed in the Grand Sable Dunes of Pictured Rocks National Lakeshore in Upper Michigan, USA. Horizontal lines above the bars show contrasts that were tested between individuals or groups of bars with associated p-values 147

Figure 4.12. Evenness of percent cover for each abundance level in areas with varying densities of spotted knapweed in the Grand Sable Dunes of Pictured Rocks National Lakeshore in Upper Michigan, USA. Horizontal lines above the bars show contrasts that were tested between individuals or groups of bars with associated p-values 148

Figure 4.13. Evenness of number of individuals for each abundance level in areas with varying densities of spotted knapweed in the Grand Sable Dunes of Pictured Rocks National Lakeshore in Upper Michigan, USA. Horizontal lines above the 
bars show contrasts that were tested between individuals or groups of bars with associated p-values 148

Figure 4.14. Linear regression of percent cover of dune $\left(\mathrm{r}^{2}=0.267, \mathrm{p}<0.001, \mathrm{df}=1,134\right)$ and non-dune $\left(\mathrm{r}^{2}=0.074, \mathrm{p}<0.001, \mathrm{df}=1,134\right)$ species related to percent cover of spotted knapweed in the Grand Sable Dunes of Pictured Rocks National Lakeshore in Alger County, Michigan 149

Figure 4.15. Linear regression of number of individual dune $\left(\mathrm{r}^{2}=0.124, \mathrm{p}<0.001, \mathrm{df}=1\right.$, 134) and non-dune $\left(\mathrm{r}^{2}=0.1885, \mathrm{p}<0.001, \mathrm{df}=1,134\right)$ plants related to the number of individual stems of spotted knapweed $\left(\mathrm{r}^{2}=.189, \mathrm{p}=0.000, \mathrm{df}=1,134\right)$ in the Grand Sable Dunes of Pictured Rocks National Lakeshore in Alger County, Michigan 150

Figure 5.1. Location of Pictured Rocks National Lakeshore in the Upper Peninsula of Michigan. The herbicide study site in the Grand Sable Dunes is highlighted in red... 170

Figure 5.2. Extent of C. maculosa invasion at the study site in the Grand Sable Dunes, Pictured Rocks National Lakeshore, Alger County, Michigan. Delineated in 2008 171

Figure 5.3. Locations of the nine study plots in the Grand Sable Dunes of Pictured Rocks National Lakeshore, Upper Michigan. Some of the plots do not appear rectangular due to topography. 172

Figure 5.4. Three by five grid layout of a single sampling block for the herbicide study in the Grand Sable Dunes of Pictured Rocks National Lakeshore, Michigan. Gray areas indicate 2 meter buffer areas between treatment areas and around plots. Numbered squares are the layout of the sampling quadrats within each subplot. Each color indicates a different treatment 173

Figure 5.5. Average species richness for each treatment in all six time periods of the herbicide study at Pictured Rocks National Lakeshore, Alger County, Michigan. $\mathrm{P}$-values are shown for the significant differences in the contrast between the control treatment and the two herbicide treatments $(\mathrm{df}=1,88 \ldots \ldots \ldots \ldots . . .175$

Figure 5.6. Diversity of average percent cover for each treatment in all six time periods of the herbicide study at Pictured Rocks National Lakeshore, Alger County, Michigan. P-values are shown for the significant differences in the contrast between the control treatment and the two herbicide treatments $(\mathrm{df}=1,88)$ 176

Figure 5.7. Diversity of average number of individuals for each each treatment in all six time periods of the herbicide study at Pictured Rocks National Lakeshore, Alger County, Michigan. P-values are shown for the significant differences in the 
contrast between the control treatment and the two herbicide treatments $(\mathrm{df}=1,88)$.

Figure 5.8. Evenness of mean percent cover in treatments of the herbicide study for Pictured Rocks National Lakeshore, Alger County, Michigan. P-values are shown for the significant differences in the contrast between the control treatment and the two herbicide treatments $(\mathrm{df}=1,88)$ 178

Figure 5.9. Evenness of mean number of individuals in treatments of the herbicide study for Pictured Rocks National Lakeshore, Alger County, Michigan. P-values are shown for the significant differences in the contrast between the control treatment and the two herbicide treatments $(\mathrm{df}=1,88) \ldots \ldots \ldots \ldots \ldots \ldots \ldots . \ldots 179$ 


\section{LIST OF TABLES}

Table 3.1. Plant species for which multi-criteria risk models were developed for Pictured Rocks National Lakeshore, Alger County, Michigan. The codes for each of the eight plant species are also included 64

Table 3.2. Ecological impacts of each invasive plant for which a model was produced. Highlighted species were the three species selected as having the potential to do the most ecological damage within the park based on life history traits and the potential habitats within Pictured Rocks National Lakeshore 65

Table 3.3. Ecological traits for each of the eight species identified as the invasive plants of the largest concern to Pictured Rocks National Park in Alger County, Michigan 66

Table 3.4. The number and percentage of random points sampled in Pictured Rocks National Lakeshore, Alger County, Michigan in $2008(n=104)$ and $2009(n=202)$ in which each species occurred 67

Table 3.5. Sources for GIS layers used in development of multi-criteria risk assessment models. 68

Table 3.6. Risk values entered into each model for soil drainage categories per each species for models developed for Pictured Rocks National Lakeshore, Alger County, Michigan. Values were determined based on life history traits determined by the literature review. BD is burdock, BW is bishop's goutweed, FM is forget-me-not, GM is garlic mustard, $\mathrm{PW}$ is periwinkle, $\mathrm{RC}$ is red clover, $\mathrm{SK}$ is spotted knapweed, and WC is sweet clover 69

Table 3.7. Risk values entered into each model for vegetation categories per each species for models developed for Pictured Rocks National Lakeshore, Alger County, Michigan. Values were assigned based on life history traits determined by the literature review. BD is burdock, BW is bishop's goutweed, FM is forget-me-not, GM is garlic mustard, PW is periwinkle, RC is red clover, SK is spotted knapweed, and $\mathrm{WC}$ is sweet clover 70

Table 3.8. Final percent influences entered into each model for each stage per invasive species after development for models developed for Pictured Rocks National Lakeshore, Alger County, Michigan 71

Table 3.9. Percent of invaded pixels correctly assigned a high risk (values 7-10) in PIRO for each stage of risk modeling. Values for the first run, the development dataset, and the final testing dataset are listed. * denotes values from Shartell 2007

. .72

Table 3.10. Total number of pixels and number of pixels testing for low, moderate, or high risk values for testing dataset for each model at each stage of invasion for 
each species. These values are valid for the eight models built for Pictured Rocks

National Lakeshore in Alger County, Michigan..................................... 73

Table 3.11. Descriptions for model layouts ................................................ 88

Table 4.1. Plant species identified and quantified in study of the impacts of spotted knapweed in a shifting dune ecosystem at Pictured Rocks National Lakeshore, Alger County, Michigan. Plants are separated into native dune species, species native to the area but not to the dunes, and species exotic to the area .... 136

Table 4.2. Mean percent cover and mean number of individuals for $100 \%$ composition of dune and non-dune plant species in different areas of spotted knapweed abundance $(\mathrm{df}=1,134)$ in the Grand Sable Dunes, Alger County, Michigan .

Table 4.3. Richness, diversity, and evenness of mean percent cover in different areas of spotted knapweed levels $(\mathrm{df}=1,134)$ in the Grand Sable Dunes, Alger County, Michigan 137

Table 4.4. Richness, diversity, and evenness of mean number of individuals in different areas of spotted knapweed levels $(\mathrm{df}=1,134)$ in the Grand Sable Dunes, Alger County, Michigan 137

Table 4.5. Mean percent cover for dune and non-dune plant species in different areas of spotted knapweed levels $(\mathrm{df}=1,134)$ in the Grand Sable Dunes, Alger County, Michigan. Plants are separated into native dune species and non-dune species, which includes species native to the area but not to the dunes and species exotic to the area .... 138

Table 4.6. Mean number of individuals for dune and non-dune plant species in different areas of spotted knapweed levels $(\mathrm{df}=1,134)$ in the Grand Sable Dunes, Alger County, Michigan. Plants are separated into native dune species and non-dune species, which includes species native to the area but not to the dunes and species exotic to the area.... 139

Table 5.1. Species quantified in the herbicide blocks in Pictured Rocks National Lakeshore, Alger County, Michigan. Status indicates "T" for state threatened species, "SC" for species of special concern, or "I" for invasive non-native plants. 175

Table 5.2. Mean percent cover for plant species found in each treatment area of the herbicide study $(\mathrm{df}=1,88)$ in the Grand Sable Dunes of Pictured Rocks National Lakeshore, Alger County, Michigan for Pre-spray 2008 (pre-2008). Plants with numbers too small for analysis are represented by " $\mathrm{M}$ ”. 180

Table 5.3. Mean number of individuals for plant species found in each treatment area of the herbicide study $(\mathrm{df}=1,88)$ in the Grand Sable Dunes of Pictured Rocks National Lakeshore, Alger County, Michigan for Pre-spray 2008 (pre-2008). Plants with numbers too small for analysis are represented by “M”...... 181 
Table 5.4. Mean percent cover for plant species found in each treatment area of the herbicide study $(\mathrm{df}=1,88)$ in the Grand Sable Dunes of Pictured Rocks National Lakeshore, Alger County, Michigan for Post-spray 2008 (post-2008). Plants with numbers too small for analysis are represented by " $\mathrm{M}$ " 182

Table 5.5. Mean number of individuals for plant species found in each treatment area of the herbicide study $(\mathrm{df}=1,88)$ in the Grand Sable Dunes of Pictured Rocks National Lakeshore, Alger County, Michigan for Post-spray 2008 (post-2008). Plants with numbers too small for analysis are represented by “M”..... 183

Table 5.6. Mean percent cover for plant species found in each treatment area of the herbicide study $(\mathrm{df}=1,88)$ in the Grand Sable Dunes of Pictured Rocks National Lakeshore, Alger County, Michigan for Pre-spray 2009 (pre-2009). Plants with numbers too small for analysis are represented by " $\mathrm{M}$ " 184

Table 5.7. Mean number of individuals for plant species found in each treatment area of the herbicide study $(\mathrm{df}=1,88)$ in the Grand Sable Dunes of Pictured Rocks National Lakeshore, Alger County, Michigan for Pre-spray 2009 (pre-2009). Plants with numbers too small for analysis are represented by “M”..... 185

Table 5.8. Mean percent cover for plant species found in each treatment area of the herbicide study $(\mathrm{df}=1,88)$ in the Grand Sable Dunes of Pictured Rocks National Lakeshore, Alger County, Michigan for Post-spray 2009 (post-2009). Plants with numbers too small for analysis are represented by " $\mathrm{M}$ " 186

Table 5.9. Mean number of individuals for plant species found in each treatment area of the herbicide study $(\mathrm{df}=1,88)$ in the Grand Sable Dunes of Pictured Rocks National Lakeshore, Alger County, Michigan for Post-spray 2009 (post-2009). Plants with numbers too small for analysis are represented by “M”..... 187

Table 5.10. Mean percent cover for plant species found in each treatment area of the herbicide study $(\mathrm{df}=1,88)$ in the Grand Sable Dunes of Pictured Rocks National Lakeshore, Alger County, Michigan for Pre-spray 2010 (pre-2010). Plants with numbers too small for analysis are represented by " $\mathrm{M}$ ". 188

Table 5.11. Mean number of individuals for plant species found in each treatment area of the herbicide study $(\mathrm{df}=1,88)$ in the Grand Sable Dunes of Pictured Rocks National Lakeshore, Alger County, Michigan for Pre-spray 2010 (pre-2010). Plants with numbers too small for analysis are represented by “M”...... 189

Table 5.12. Mean percent cover for plant species found in each treatment area of the herbicide study $(\mathrm{df}=1,88)$ in the Grand Sable Dunes of Pictured Rocks National Lakeshore, Alger County, Michigan for Post-spray 2010 (post-2010). Plants with numbers too small for analysis are represented by " $\mathrm{M}$ ". 190

Table 5.13. Mean number of individuals for plant species found in each treatment area of the herbicide $(\mathrm{df}=1,88)$ study in the Grand Sable Dunes of Pictured Rocks 
National Lakeshore, Alger County, Michigan for Post-spray 2010 (post-2010).

Plants with numbers too small for analysis are represented by "M"..... 191 


\section{LIST OF EQUATIONS}

Equation 3.1. Equation for determining random sampling size ....................... 47

Equation 4.1. Shannon-Wiener diversity index............................................. 120

Equation 4.2. Species evenness ............................................................... 121

Equation 5.1. Shannon-Wiener diversity index ............................................ 158

Equation 5.2. Species evenness ............................................................ 158 


\section{ACKNOWLEDGEMENTS}

I am grateful for the guidance and encouragement from my advisor, Dr. Andrew Storer, throughout my time as a student at Michigan Tech.

I would also like to thank my committee members, Dr. Linda Nagel, Dr. Robert Heyd, and Dr. Hugh Gorman for their valuable advice and direction throughout my graduate education.

Special thanks are directed to Bruce Leutscher from Pictured Rocks National Lakeshore, who helped to make my years of projects run smoothly and allowed me to work at the best field site a person could ask for. A special thanks also to Mike Hyslop for his guidance and feedback throughout these projects.

Thank you to Pictured Rocks National Lakeshore and their Exotic Plant Management Team and to the Ford Forestry Center for funding and field site locations.

Thank you to Matt Abbotts, Hannah Abbotts, Adrienne Bozic, Marcella Campione, Katherine Grzesiak, Andrew Hallfrisch, Joseph Latsch, Lindsey Shartell, and Donavon Young for your enthusiasm and assistance in the field and in the laboratory.

Thank you to all of my friends and family who have helped me throughout this process. You are too numerous to name, but your support has been astounding. 


\section{ABSTRACT}

Ecological disturbances may be caused by a range of biotic and abiotic factors. Among these are disturbances that result from human activities such as the introduction of exotic plants and land management activities. This dissertation addresses both of these types of disturbance in ecosystems in the Upper Peninsula of Michigan.

Invasive plants are a significant cause of disturbance at Pictured Rocks Natural Lakeshore. Management of invasive plants is dependent on understanding what areas are at risk of being invaded, what the consequences of an invasion are on native plant communities and how effective different tools are for managing the invasive species. A series of risk models are described that predict three stages of invasion (introduction, establishment and spread) for eight invasive plant species at Pictured Rocks National Lakeshore. These models are specific to this location and include species for which models have not previously been produced. The models were tested by collecting point data throughout the park to demonstrate their effectiveness for future detection of invasive plants in the park. Work to describe the impacts and management of invasive plants focused on spotted knapweed in the sensitive Grand Sable Dunes area of Pictured Rocks National Lakeshore. Impacts of spotted knapweed were assessed by comparing vegetation communities in areas with varying amounts of spotted knapweed. This work showed significant increases in species diversity in areas invaded by knapweed, apparently as a result of the presence of a number of non-dune species that have become established in spotted knapweed invaded areas. An experiment was carried out to compare annual spot application of two herbicides, Milestone $\AA$ and Transline $\AA$ to target spotted knapweed. This included an assessment of impacts of this type of treatment on non-target species. There was no difference in the effectiveness of the two herbicides, and both significantly reduced the density of spotted knapweed during the 
course of the study. Areas treated with herbicide developed a higher percent cover of grasses during the study, and suffered limited negative impacts on some sensitive dune species such as beach pea and dune stitchwort, and on some other non-dune species such as hawkweed. The use of these herbicides to reduce the density of spotted knapweed appears to be feasible over large scales. 


\section{CHAPTER 1}

\section{INTRODUCTION}

\section{Introduction}

Disturbance and invasion ecology are two disciplines of ecology that are perpetually intertwined. Disturbances can have an effect on plant composition in a given ecosystem and can provide opportunity for invasive plant introduction. Invasive plants could also be considered a disturbance in themselves, especially when they alter ecosystem function.

Plants have been introduced around the world both accidentally and deliberately. In the United States, $82 \%$ of the 235 species of woody plant invaders were introduced as ornamentals or for landscaping (Myers and Bazely 2003). Introductions of non-native species around the world are leading to increasing global homogenization (Wilsey 2005). Often, plants are introduced for a purpose such as preventing soil erosion (e.g. Russian olive (Elaeagnus angustifolia L.), multiflora rose (Rosa multiflora Thunb.), kudzu (Pueraria Montana Lour.), and salt cedar (Tamarix ramosissima Ledeb.). Old rangelands in the western United States are extensively invaded by non-native grasses, mostly in the past 30 years (Wilsey 2005).

The United States spends approximately $\$ 125$ billion per year on invasive species (Baker 2001). More than 40 million hectares in the U.S. are currently occupied by invasive species and those populations are expected to spread at an annual rate of 1.2 million hectares (National Invasive Species Council 2001). Of 2,490 imperiled species in the United States, 57\% are threatened due to alien species (Wilcove et al. 1998). 
Invasive plants in the United States are expected to continue being introduced and spread throughout the country (Zavaleta and Rovval 2002). Many of the studies conducted to ascertain whether introduced species cause extinction are based on invasive animals and diseases (Campbell 2001). There is a lack of quantitative studies evaluating the localized effects of invasive plants on native plant communities, especially related to disturbances (Wilcove et al. 1998).

\section{Disturbance Ecology}

Disturbances can be nature's way of refreshing an ecosystem. Changes in disturbance regimes are common through geologic time (Dale et al. 2001) and areas that are affected by disturbances are often more vulnerable to invasion because the ecological system has been disrupted (Dekker 2005). Interrupting that cycle can affect plant communities in significant and unpredictable ways and different types of disturbances may have different effects on plant dynamics (Dale et al. 2001; Frelich 2002; Dekker 2005).

Abiotic disturbances could include climate change and resulting weather patterns including precipitation and temperature (Beard 1978; Orians and Paine 1983; Stephenson 1988; Iverson and Prasad 1998; Dale et al. 2001; Frelich 2002; Walther et al. 2002; Mooney et al. 2005; IPCC 2007; Kelly and Goulden 2008), ice storms (Dale et al. 2001), windstorms (Dale et al. 2001), hurricanes (Dale et al. 2001), or fire (Mooney and Hobbs 2000, Dale et al. 2001, Frelich 2002). Biotic disturbances could include insect and pathogen outbreaks (Dale et al. 2001; Carroll et al. 2004; Breshears et al. 2005; Kurz et al. 2008; Regniere and Bentz 2009; Sturrock et al. 2011), mammalian herbivory (Mladenoff and Stearns 1993; Frelich 2002), forest management (Radosevich et al. 2007), and even introduced species. 
The effects of disturbances can be complex and cascading. Drought can stress trees, making them more prone to insect attacks, disease, or fire (Dale et al. 2001). Insect attacks on trees can leave a stand vulnerable to fires by increasing fuel loads (Mooney and Hobbs 2000). Low-intensity fires can create opportunity for insect attack by compromising tree defenses. Anthropogenic activities that interrupt or exacerbate disturbance cycles can have even more unpredictable effects on plant communities (Hurteau and North 2008). This dissertation focuses on two major sources of disturbance: fire as a forest management tool and introduced species. Fire is explored as a disturbance to promote jack pine regeneration, while invasive species are assessed as a disturbance in Pictured Rocks National Lakeshore. Not only did was invasion by an exotic plant into a rare dune ecosystem assessed, but the effects of herbicide application on native and non-native plants were also assessed.

Fire

Fires are a necessary disturbance in certain ecosystems (e.g. boreal forests) and aid in nutrient cycling, gap creation, change in forest successional stage, and preparing seed beds (Frelich 2002). Fire regimes will potentially have a rapid response to climate change (Dale et al. 2001). Weather patterns are changing and as a result, fire regimes will change (Randerson et al. 2006). Some fire histories indicate that the frequency of fire can decrease with warmer temperatures because of increased precipitation (Frelich 2002). Areas in the U.S. that become more arid due to the changing climate may be subjected to 25-50\% more area burned (Dale et al. 2001).

Besides being dependent on forest structure and composition, the size, intensity, seasonality, frequency, and type of fires is highly dependent on climatic conditions (Dale et al. 2001). For example, crown fires are rare in northern hardwoods due to high 
moisture content in the canopy, but fire would be even more limited in size, intensity, and frequency if precipitation is high (Frelich 2002).

Increasing carbon dioxide and nitrogen deposition levels may allow increased biomass production (Randerson et al. 2000). Increased above-ground biomass results in more fuel for fires, which may create larger and more intense fires (Dale et al. 2001). Fires allow an abundance of early-successional species like invasive plants to establish in an ecosystem (Dale et al. 2001).

Research in boreal forests has focused on the tree component, but understory components are also important considerations (Nilsson and Wardle 2005). Not only can understory vegetation influence seedling regeneration, but they can also alter abiotic factors below the soil. A study in the boreal forest of Sweden showed that invasive shrubs tend to become dominated by invasive plants with increasing time after fire disturbance (Nilsson and Wardle 2005). Those invasive shrubs can have an even stronger effect on seedling regeneration by producing increased but poor-quality litter as well as allelopathic compounds. The study also found that the allelopathic chemicals leach into nearby waterways when snow melts (Nilsson and Wardle 2005).

\section{Introduced Species}

Invasive plants are plants that have been introduced to an area and have been shown to seriously threaten biodiversity, structure, or function of a region's ecosystems. A widely accepted definition is that invasive plants are plants that are introduced by humans and proceed to successfully establish, spread, and become naturalized without further anthropogenic assistance (Randall 1997). Many plants are introduced to areas in which they are not native, but only a fraction of those become invasive plants or weeds (Williamson and Fitter 1996). Invasive species can alter many ecological processes, 
including ecological succession, especial in habitats that are frequently disturbed (Vitousek 1990; Walker and Vitousek 1991; D’Antonio and Vitousek 1994; Leege and Murch 2001). Other effects of invasive plants include decreases in biodiversity, loss of habitat, change of ecosystem function, and change in disturbance regimes (Daehler and Strong 1994; Wilcove et al. 1998; Parker et al. 1999; Alien Plant Working Group 2002). Next to changing land use patterns, invasive species are the most prevalent cause of extinction (Vitousek et al. 1996).

More than 4,500 non-native species had been introduced in the United States as of 2000 (Rejmanek 2000). This is approximately $21 \%$ of an estimated 22,000 plants in the country. If this rate of introduction continues at its current pace, the planet's plant populations could eventually homogenize to only a few highly successful species (Radosevich et al. 2007). Estimates of economic losses due to invasive species in the United States are approximately $\$ 120$ billion (Pimental et al. 2005). Currently, every county in the United States has documented at least one invasive plant within its boundaries (Stohlgren et al. 2006). Approximately $42 \%$ of the species listed on the United States Threatened and Endangered Species List are on that list as a result of threats from introduced species (Wilcove et al. 1998).

Humans have made weeds and invasive plants worldwide problems by advances in transportation, trade, and human values (Mack and Lonsdale 2001; Radosevich et al. 2007). Anthropogenic environmental changes can cause a response in invasive plants, but invasive plants can also initiate environmental change through dominating plant communities (Pyke and Knick 2003; Hobbs et al. 2006). Controlling invasive species can benefit human populations in ways such as lowering the price of food, a higher abundance (and hence lower cost) of lumber, and create more recreational opportunities (Radosevich et al. 2007). 
The invasion of introduced species into communities could be considered a special incidence of forest succession (Dale et al. 2001). Plant communities are highly dynamic but predicting the pathways of change is difficult (Firbank et al. 1995). Disturbance may promote the colonization and expansion of non-native species; therefore, intact plant communities should be resistant to invasion (Radosevich et al. 2001). However, scientists disagree whether plant communities with high species diversity or a community with low species diversity are more easily invaded (Daehler and Strong 1994; Wilcove et al. 1998; Radosevich et al. 2001).

Few plant communities are resistant to invasion and those plant communities that become invaded by non-native plants can become so altered that it is not possible for those communities to return easily to an unaltered state (Radosevich et al. 2007). The establishment of introduced species in new plant communities can indicate the presence of empty niches in the native community, a new niche being created by the invasive species, or the invasive species is a superior competitor adapted to respond to disturbance or utilize resources better than native species (Myers and Bazely 2003).

Despite continuing research, the interactions between invasive plants and biodiversity are continually debated (Radosevich et al. 2007). While scientists maintain that plant communities with lower diversity are more susceptible to invasion, other scientists maintain that communities with a higher diversity are more susceptible (Radosevich et al. 2001). Yet other scientists hypothesize that there is no consistent relationship between biodiversity and invasion because the relationship depends on the scale at which measurements are made (Radosevich et al. 2007).

Invasive plants may have different effects on the understory than they might have on the overstory (Myers and Bazely 2003). Woody invasive plants may have better 
success at out-competing species in the overstory than herbaceous invasive plants; however, trees are well-adapted to ensure they obtain the resources they need (Myers and Bazely 2003). Invasive woody species may be dense along corridors, but tend not to spread too far into a forest interior because resource availability is monopolized by the overstory trees (Myers and Bazely 2003). Invasive plants tend to have better mechanisms for invasion into forest interiors due to their lower resource needs (Myers and Bazely 2003).

Priorities for invasive plant management are generally based on the risk of establishment and the value of the land at risk of invasion (Hobbs and Humphries 1995, Hiebert 1997). Species targeted for control could be influenced by legal mandates, county regulations, and a sense of values based on societal considerations (Stohlgren and Jarnevich 2009). Societal considerations might include threats to rare plants or habitats, private property rights, or unfairly distributed costs of control (Stohlgren and Jarnevich 2009).

The effects of a single invasive plant can be negligible; however, the aggregate effects of multiple invasive plants can be overwhelming in an ecosystem (National Research Council 2002). Impacts of invasive plants can be severe in a given ecosystem and the simplest approach to controlling weeds is to directly control them with a goal of reducing abundance (Radosevich et al. 2007). More than $\$ 100$ billion is spent annually in the United States on the use of herbicides and pests and associated crop losses due to controlling invasive species (Pimentel et al. 2000). That exorbitant amount of money spent on control of weeds in agricultural systems is a fraction of what is spent on nationwide invasive species control. 
The most difficult invaders to control are those that affect ecosystem processes such as disturbance regimes (Vitouselk and Walker 1989; Mack and D’Antonio 1998). The impacts of invasion are often impossible to quantify due to lack of data on the species composition, structure, and function of ecosystems before they are invaded (National Resource Council 2002). Invasion ecologists generally agree that prevention of initial introduction is the most effective way to limit plant invasions (Kolar and Lodge 2001). Ongoing advances in technology, trade, and transportation make prevention more difficult, while changing environmental conditions (both local and global) and changing patterns of land use make prevention even more unattainable (Myers and Bazely 2003). Areas at risk for invasion by certain plants can be identified and monitored as a step towards preventative management using a species-focused approach to modeling (Shartell 2007; Shartell et al. 2010).

Predicting the potential new range of an introduced species could be useful in predicting new ranges of native plants as the climate changes (National Research Council 2002). However, collecting these data in an ecologically meaningful way continues to be a challenge. Predicting a plant response to climate change is problematic due to the assumption that climate is the only driving factor behind the distribution of the species (National Research Council 2002). However, taking every factor into account is difficult, if not impossible. Prediction of these distributions can be made even more difficult considering that some species can tolerate wider climatic ranges than they might be confined to in their native or current distributions (National Research Council 2002).

Herbicides can be used to effectively reduce weed density and effects are generally rapid (Radosevich et al. 2007). A common trend in areas sprayed repeatedly with herbicides is the increase of herbicide-tolerant plants (Radosevich et al. 2007), so caution is needed when repeatedly using herbicides as a control method. Herbicides can 
also have effects on species not targeted for control, so additional caution should be used in areas with an abundance of non-target plants.

Disturbance and recruitment of introduced species are both associated with human activities. It is important to distinguish between long-term disturbance and disturbance at the time of invasion. Humans might suppress the frequency of disturbance (i.e. fire and flooding) and that could influence the invasibility or species composition of communities.

Land managers can change land use to discourage introduction, establishment, or spread of introduced species, but anthropogenic values of an area may prevent such changes (Radosevich et al. 2007). In natural areas like Pictured Rocks National Lakeshore in the Upper Peninsula of Michigan, changes in human values and behavior might be required to reduce instances of introduction.

When an area is targeted for restoration after invasion, the most important concern is whether the impacts of the invaders can be reversed or if the community will reach a state of equilibrium (Myers and Bazely 2003). Restoration is complex and unpredictable. By the time an introduced species is acknowledged as a problem, it is not probable that eradication is achievable, so the most common solution is to try to control the invader with chemical or biological method. Invasive plants are continual ecological problems that can both act as a disturbance or invade as a response to a disturbance.

Although scientists may not agree about how or to what extent plants will be affected, they do agree that climate change will have an effect on biological traits, distribution, and abundance of native and invasive plants alike (Belote et al. 2003; Intergovernmental Panel on Climate Change 2007; Bradley et al. 2009). 
The changing climate will probably alter the abundance of invasive species, but we do not yet have enough information to accurately predict these trends (Radosevich et al. 2001). Habitats will be altered as our climate changes, creating new openings for invasive plants (Myers and Bazely 2003). Changing land usage may favor opportunistic species, giving plant populations opportunity to develop more invasive characteristics (Radosevich et al. 2001). Disturbance and habitat fragmentation will create space for species with short life cycles, well-developed dispersal patterns, and high reproduction rates to move in before longer-lived, slow-growing species can (Frelich 2002; Myers and Bazely 2003).

\section{Disturbances and Plant Communities}

Generalizations about the effects of disturbances on species diversity are difficult because disturbances can have a complex and compounding effect. Not only do natural disturbances have an effect on biodiversity, but human disturbances also affect species richness (Huteau and North 2008). Humans have interrupted natural disturbance regimes, which can cause more intense disturbances. For instance, suppressing fire causes fuel loads in forests to increase because they are not controlled on a regular cycle as they would without human interference (Dale et al. 2001). Now when those fuel loads are ignited less often, they can become high-intensity crown fires instead of lowerintensity fires that may have been easier to control (Dale et al. 2001).

Susceptibility to plant invasions varies by plant community. Disturbed habitats, for instance, have an increased vulnerability to invasion, whereas forests that remain in late successional phases for extended periods of time are less vulnerable to invasion (Radosevich et al. 2007). As succession progresses, species richness and plant sizes increase (Pausas and Austin 2001). Evenness is stronger in early succession when resources are abundant and weaker in later succession (Radosevich et al. 2007). 
After a disturbance, the most ecologically-friendly response might be to forgo management, but there is usually a call for some type of cleanup or restoration (Dale et al. 2001). Preventative management may be the most economical management technique, but despite practicing sound management, natural disturbances will still occur. For example, density management can reduce stressors in a forest to maintain stand vigor and discourage insect attacks, species introductions could be regulated, or controlled burns could be used to reduce fuel loads (Frelich 2002). If preventative measures fail and a disturbance does affect a forest, salvage practices can be implemented, as can recovery processes (e.g. planting or seeding). Careful thought should go into recovery practices to prevent long-term impacts that could cause more intense disturbances (e.g. damaging live trees during a salvage operation).

Human management of land can also affect disturbances and resulting plant communities. Humans are the main vectors for invasive species, and those species can modify existing regimes or cause their own disturbances (Dale et al. 2001). Effects of climate change on those interactions are unpredictable (Intergovernmental Panel on Climate Change 2007). Managed forests are more likely to be invaded than unmanaged areas, probably due to increase in human activity (Thomas et al. 1999). Seeds from invasive plants can be brought in on machinery and the disturbance from logging can create suitable introductive habitat. Movement of fill can also create an opportunity for seeds in the transported soil to establish in a new area. Overall, invasive species are a disturbance that may cause changes from which there is no recovery.

\section{Summary}

Disturbance ecology and invasion ecology are interdisciplinary fields of ecology. Invasive species could be considered a form of disturbance when they interrupt 
succession and disturbances enable invasive species to establish. This cycle can be broken, but only with diligence and abundant resources. Pictured Rocks National Lakeshore, a park that has been subjected to multiple disturbances, is a National Park in the Upper Peninsula of Michigan (Figure 1.1). A case history of invasive plants and their management in Pictured Rocks National Lakeshore gives insight to effectiveness of control and federal guidelines for invasive plant control (Chapter 2). This dissertation describes three studies implemented in Pictured Rocks National Lakeshore in response to invasive plants, which have generally been provided opportunities for establishment by disturbances. The first study developed and tested multi-criteria risk assessment models for eight invasive plants (Chapter 3). These should aid the park in their control efforts. The second study aimed to quantify the impacts of spotted knapweed (Centaurea maculosa Lamb.) on native and non-native plant populations in the Grand Sable Dunes (Chapter 4). The third study assessed the effectiveness of two herbicides on spotted knapweed as well as non-target effects on native dune plants (Chapter 5). A fourth study described in this dissertation was a study conducted in the Baraga Plains of the Upper Peninsula (Figure 1.1) which also assessed the effects of management as a disturbance on plant populations (Chapter 6).

\section{Literature Cited}

Alien Plant Working Group. 2002.Weeds Gone Wild: Alien Plant Invaders of Natural Areas. Plant Conservation Alliance. http://www.nps.gov/plants/alien/bkgd.htm. Accessed: January 1, 2011.

Baker, B. 2001. National management plan maps strategy for controlling invasive species. Bioscience 51: 92.

Beard, J.S. 1978. The physiognomic approach. Pp. 33-64 in R.H. Whittaker, ed. Classification of plant communities. Junk, The Hague.

Belote, T.R., J.F. Weltzin, R.J. Norby. 2003. Response of an understory plant community to elevated $\mathrm{CO} 2$ depends on differential responses of dominant invasive species and is mediated by soil water availability. New Phytologist161: 827-835. 
Bradley, B.A., M. Oppenheimer, D.S. Wilcove. 2009. Climate change and plant invasions: restoration opportunities ahead? Global Change Biology 15: 1511-1521.

Breshears, D.D., N.S. Cobb, P.M. Rich, K.P. Price, C.D. Allen, R.G. Balice, W.H. Romme, J.H. Kastens, M.L. Floyd, J. Beinap, J.J. Anderson, O.B. Myers, and C.W. Meyer. 2005. Regional vegetation die-off in response to global-change-type drought. Proceedings of the National Academy of Sciences 102(42): 15144-15148.

Carroll, A.L., S.W. Taylor, J. Regniere, and L. Safranyik. 2004. Effects of climate change on range expansion by the mountain pine beetle in British Columbia. Pp. 223-232 in I. Shore, J.E. Brooks, and J.E. Stone, eds. Mountain Pine Beetle Symposium: Challenges and Solutions. National Resources Canada, Canadian Forest Service, Pacific Forestry Centre, Kelowna, BC.

D'Antonio C.M, and P.M. Vitousek.1992.Biological invasions by exotic grasses, the grass/fire cycle, and global change. Annual Review of Ecology and Systematics 23: $63-87$.

Daehler C.C. and D.R. Strong. 1994. Native plant bio- diversity vs. the introduced invaders: status of the conflict and future management options. Pp. 92-113 in S.K. Majumdar, F.J. Brenner, J.E. Lovich, J.F. Schalles, E.W. Miller , eds. Biological Diversity: Problems and Challenges. Easton, PA: Penn. Acad. Sci.

Dale, V.H., L.A. Joyce, S. McNulty, R.P. Neilson, M.P. Ayers, M.D. Flannigan, P.J. Hanson, L.C. Irland, A.E. Lugo, C.J. Peterson, D. Simberloff, F.J. Swanson, B.J. Stocks, and B.M. Wotton. 2001. Climate change and forest disturbances. BioScience 51 (9): 723-734.

Dekker, J. 2005. Biology and anthropology of plant invasions. Pp. 235-250 in O. Inderjit, ed. Invasive Plants: Ecological and Agricultural Aspects. Birkhauser Verlag, Switzerland.

Firbank, L.G., A.R. Watkinson, L.R. Norton, T.W. Ashenden. 1995. Plant populations and global environmental change: the effect of different temperature, carbon dioxide, and nutrient regimes on density dependence in populations of Vilpia ciliata. Journal of Applied Ecology 9: 432-441.

Frelich, L.E. 2002. Forest Dynamics and Disturbance Regimes. Cambridge University Press: New York. 266 pp.

Hiebert, R.D. 1997. Prioritizing invasion plants and planning for management. Pp. 195212 in J.O. Luken and J.W. Thieret, eds. Assessment and Management of Plant Invasions. Springer-Verlag, New York, NY.

Hobbs, R.J. and S.E. Humphries. 1995. An integrated approach to the ecology and management of plant invasions. Conservation Biology 9:761-770.

Hobbs, R.J., A. Salvatore, J. Aronson, J.S. Baron, P. Bridgewater, V.A. Cramer, P.R. Epstein, J.J. Ewel, C.A. Klink, A.E. Lugo, D. Norton, D. Ojima, D.M. Richardson, E.S. Sanderson, F. Valladares, M. Villa, R. Zamora, and M. Zobel. 2006. Novel ecosystems: theoretical and management aspects of the new ecological world order. Global Ecology and Biogeography. 15:1-17. 
Hurteau, M. and M. North. 2008. Mixed-conifer understory response to climate change, nitrogen, and fire. Global Change Biology 14: 1543-1552.

Intergovernmental Panel on Climate Change. 2007. In S. Solomon, D. Qin, M. Manning, Z. Chen, M. Marquis, and K.B. Averyt, eds. Climate Change 2007: The Physical Science Basis. Contribution of Working Group I to the Fourth Assessment Report of the Intergovernmental Panel on Climate Change. Cambridge University Press, Cambridge, UK.

Iverson, L.R. and A.M. Prasad. 1998. Predicting abundance of 80 tree species following climate change in the eastern United States. Ecological Monographs 68(4): 465485 .

Kelly, A.E. and M.L. Goulden. 2008. Rapid shifts in plant distribution with recent climate change. Proceedings of the National Academy of Sciences 105(33): 1182311826.

Kolar, C.S. and D.M. Lodge. 2001. Progress in invasion biology: predicting invaders. Trends in Ecology and Evolution 16:199-204.

Kurz, W.A., C.C. Dymond, G. Stinson, G.J. Rampley, E.T. Neilson, A.L. Carroll, T. Ebata, and L. Safranyik. Mountain pine beetle and forest carbon feedback to climate change. Nature 452: 987-990.

Leege, L.M. and P.G. Murphy. 2001. Ecological effects of the non-native Pinus nigra on sand dune communities. Canadian Journal of Botany 79:429-437.

Mack, R.N., and W.M. Lonsdale. 2001. Humans as global plant disperseres: getting more than we bargained for. BioScience 51:95-102.

Marshall, J.M., A.J. Storer, and B. Leutscher. 2008. Comparative analysis of plant and ground dwelling arthropod communities in lacustrine dune areas with and without Centaurea biebersteinii (Asteraceae). The American Midland Naturalist 159(2):261-274.

Meiners, S.J. and M.L. Cadenasso. 2005. The relationship between community diversity and exotic plants: cause or consequence of invasion? Invasive plants: Ecological and Agricultural Aspects. Pp. 97-114.

Mladenoff, D.J. and F. Stearns. 1993. Eastern Hemlock Regeneration and Deer Browsing in the Northern Great Lakes Region: A Re-examination and Model Simulation. Conservation Biology 7(4): 889-900.

Mooney, H.A. and R.J. Hobbs. 200o. Invasive species in a changing world.Washington, D.C.: Island Press. 457 p.

Mooney, H.A., L.E. Neville, P.J. Schei, J.K. Waage, R.N. Mack, J.A. McNeely, eds. 2005. Invasive Alien Speices: A New Synthesis. Washington, D.C.: Island Press. 368 p.

Myers, J.H., and D.R. Bazely. 2003. Ecology and Control of Introduced Plants. University Press: Cambridge. 313 pp. 
Nilsson, M.C., and D.A. Wardle. 2005. Understory vegetation as a forest ecosystem driver: evidence from the northern Swedish boreal forest. Frontiers in Ecology and the Environment 3(8): 421-428.

National Invasive Species Council. 2001. Meeting the invasive species challenge: national invasive species management plan. Washington, DC: US Government. 89 p.

National Research Council. 2002. Predicting invasions of nonindigenous plants and plant pests. Washington D.C.: National Academy Press.

Orians, G.H. and R.T. Paine. 1983. Convergent evolution at the community level. Pp 431458 in D.J. Futuyma and M. Slatkin, eds. Coevolution. Sinauer, Sunderland, Massachusetts.

Parker, I.M., D. Simberloff, W.M. Lonsdale, K. Goodell, M. Wonham, P.M. Kareiva, M.H. Williamson, B. Von Holle, P.B. Moyle, J.E. Byers, and L. Goldwasser. 1999. Impact: toward a framework for understanding the ecological effects of invaders. Biological Invasions. 1:3-19.

Pausas, J.G., and M.P. Austin. 2001. Patterns of plant species richness in relation to different environments: an appraisal. Journal of Vegetation Science 12: 153-166.

Pimentel, D., L. Lach, R. Zuniga, and D. Morrison. 2000. Environmental and economic costs of nonindigenous species in the United States. BioScience 5O(1): 53-65.

Pyke, D.A. and S.T.Knick. 2003. Plant invaders, global change and landscape restoration. Pp. 278-288 in N. Allsopp, A.R. Palmer, S.J. Milton, K.P. Kirkman, G.I.H. Kerley, and D.R. Brown, eds. Proceedings of the VII International Rangelands Congress. International Rangeland Congress, Durban, South Africa.

Radosevich, S.R., J.S. Holt, C.M. Ghersa. 2007. Ecology of Weeds and Invasive Plants. Hoboken, New Jersey: John Wiley \& Sons, Inc.. 454p.

Randall, J.M. 1997. Defining weeds of natural areas. Pp. 18-25 in J.O. Luken and J.W. Thieret, eds. Assessment and Management of Plant Invasions. New York: Springer-Verlag.

Randerson, J.T., H. Liu, M.G. Flanner, S.D. Chambers, Y. Jin, P.G. Hess, G. Pfister, M.C. Mack, K.K. Treseder, L.R. Welp, F.S. Chapin, J.W. Harden, M.L. Goulden, E. Lyons, J.C. Neff, E.A.G. Schuur, and C.S. Zender. 2006. The impact of boreal forest fire on climate warming. Science 314: 1130-1131.

Regniere, J. and B. Bentz. 2009. Pp 63-64 in K.A. McManus and K.W. Gottschalk, eds. Proceedings of the 19th U.S. Department of Agriculture interagency research forum on invasive species 2008; 2008 January 8-11; Annapolis, MD. Gen. Tech. Rep. NRS-P-36. Newtown Square, PA: U.S. Department of Agriculture, Forest Service, Northern Research Station.

Rejmánek, M. 2000. Invasive plants: Approaches and predictions. Australian Ecology 25:497-506. 
Stephenson, N.L. 1988. Climatic control of vegetation distribution: the role of the water. The American Naturalist 135(5): 649-670.

Stohlgren, T.J., and C.S. Jarnevich. 2009. Risk Assessment of invasive species. Pp. 19-35 in M.N. Clout and P.A. Williams, eds. Invasive Species Management. Oxford University Press, Oxford.

Stohlgren, T.J., D. Barnett, C. Flather, P. Fuller, B. Peterjohn, and J. Kartesz. 2006. Species richness and patterns of invasion in plants, birds, and fishes in the United States. Biological Invasions 8:427-457.

Sturrock, R.N., S.J. Frankel, A.V. Brown, P.E. Hennon, J.T. Kliejunas, K.J. Lewis, J.J. Worrall, and A.J. Woods. 2011. Climate change and forest diseases. Plant Pathology 60: 133-149.

Thomas, S.C., C.B. Halpern, D.A. Falk, D.A. Liguori, and K.A. Austin. 1999. Plant diversity in managed forests: understory responses to thinning and fertilization. Ecological Applications 9: 864-879.

Vitousek PM. 1990. Biological invasions and ecosystem processes: towards an integration of population biology and ecosystem studies. Oikos 57:7-13

Vitousek, P.M., C.M. D’Antonio, L.L. Loope, and R. Westbrooks. 1996. Biological invasions as global environmental change. American Scientist 84:468-478.

Walther, G.R., E.Post, P. Convey, A. Menzel, C. Parmesan, T.J.C. Beebee, J.M. Fromentin, O. Hoegh-Guldberg, and F. Bairlein. Ecological responses to recent climate change. Nature 416: 389-395.

Wilcove, D.S., D. Rothstein, J. Bubow, A. Phillips, and E. Losos. 1998. Quantifying threats to imperiled species in the United States. BioScience 48(8): 607-615.

Williamson, M .and A. Fitter, A. 1996. The characters of successful invaders. Biological Conservation 78: 163-170.

Wilsey, B.J. 2005. Importance of species replication in understanding plant invasions into North American grasslands. Pp. 61-75 in O. Inderjit, ed. Invasive Plants: Ecological and Agricultural Aspects, Birkhauser Verlag, Switzerland. 


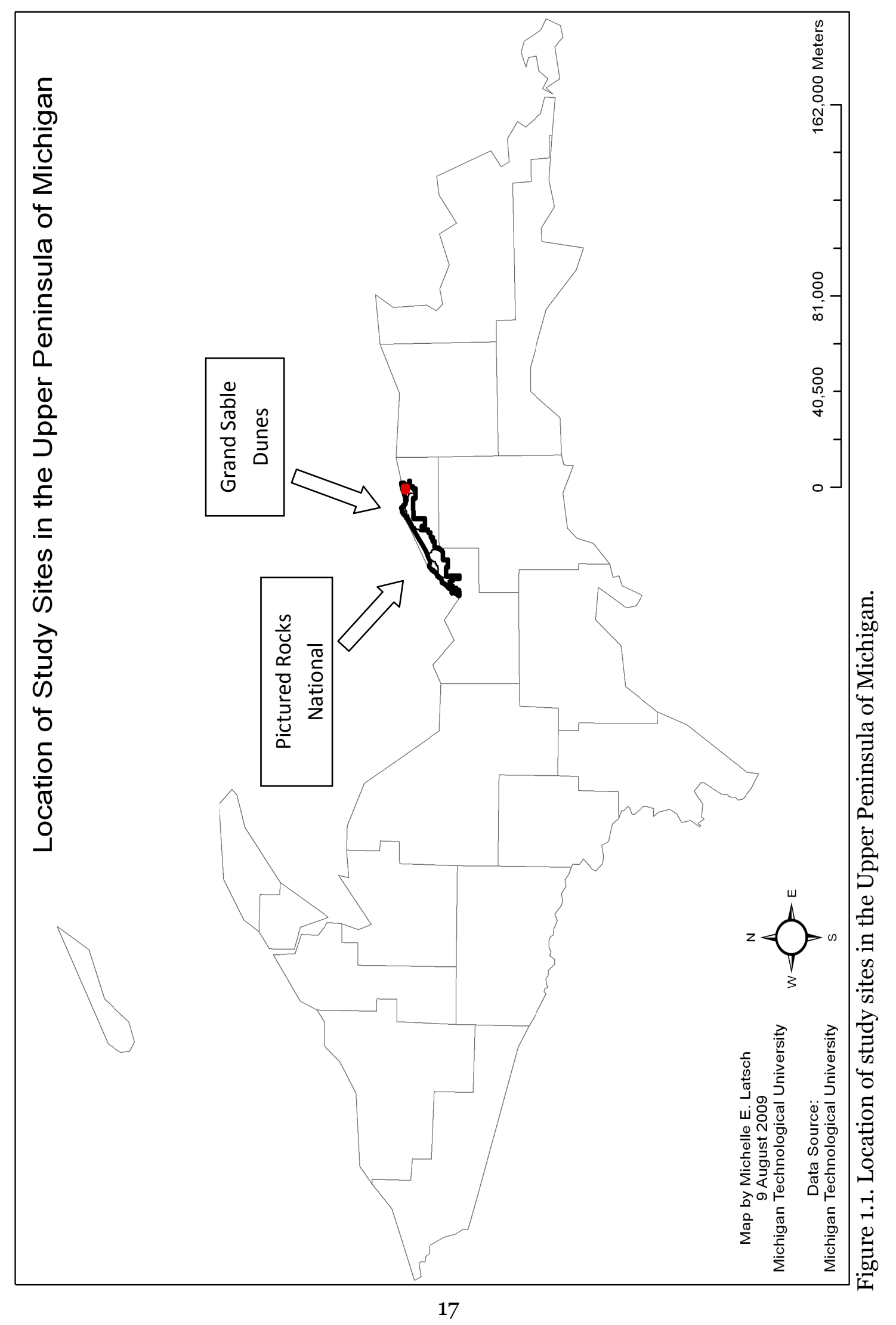




\section{CHAPTER 2}

\section{HISTORY AND POLICY OF \\ INVASIVE PLANT MANAGEMENT IN \\ PICTURED ROCKS NATIONAL LAKESHORE \\ IN ALGER COUNTY, MICHIGAN}

\section{Introduction}

Invasive plants, or plants that are introduced and proceed to spread outside their introduced range (Myers 1997; Freeman et al. 2009), are often difficult and expensive to control. They can be especially challenging to control in natural preservation areas like Pictured Rocks National Lakeshore, where funding is inadequate for large-scale eradication programs. Despite funding inadequacies, control of invasive plants remains a high priority for the Lakeshore. Its dedication and perseverance to the control of invasive plants in the park despite numerous other opportunities on which they could spend their funding provides a unique case study.

The lack of funds necessary to completely preserve the ecological integrity of the National Lakeshore has caused the park to pursue different solutions to the management problems invasive plants create with in the park. One of these solutions is the use of multi-criteria GIS risk assessment models to identify areas of the park most at risk for introduction, establishment, and spread of different plant species. In addition, the active lacustrine dunes within the park are a rare ecosystem high on the priority list for preservation. Hence, experimental procedures have tested the efficacy of two herbicides approved for park use on spotted knapweed (Centaurea maculosa Lamb.) as well as the 
non-target effects of those herbicides. Due to the results of this herbicide study, the park is considering an unprecedented widespread herbicide application within the dune ecosystem (Latsch et al. unpublished data). The strategies for invasive plant control at Pictured Rocks National Lakeshore can be viewed as an example to other National Park units interested in developing proactive approaches to invasive plant control.

\section{Invasive Species}

Invasive plants can cause damage in many ecosystems (including biodiversity loss) and associated costs for controlling them can rapidly inflate. For centuries, plants have been introduced outside their native ranges for agriculture and horticulture with minimal research into the potential impacts (Freeman et al. 2009). When those species start establishing and spreading outside their introduced location, they qualify as invasive species. Invasive species are one of the most common causes of worldwide biodiversity loss (Myers 1997; Mooney and Hobbs 2000; Sala et al. 2000). In the United States, $49 \%$ of all at-risk species are threatened by competition with invasive species (Wilcove et al. 1998). More than 40.5 million hectares of the total 981 million hectares comprising the United States are occupied by invasive plants, and invaded acreage is expected to expand at an unprecedented rate of 1.2 million hectares per year (Vitousek et al. 1997; McNeely et al. 2001; National Invasive Species Council 2001; Westbrooks et al. 2001). Currently, invasive plants are present in every county in the United States as well as every country in the world (Reaser et al. 2003; Stohlgren et al. 2006). Invasive species also cost the United States approximately $\$ 120$ billion per year for damages caused by all invasive species and associated control efforts (Pimental et al. 2005).

If control methods are not undertaken an early stage of invasion, the biodiversity losses caused by invasive plants can become greater than what a single organization such 
as Pictured Rocks National Lakeshore can feasibly handle. For example, if garlic mustard (Alliaria petiolata M. Bieb.) is allowed to establish and spread into a forest, it can create a monoculture in the understory from which there is little chance of restoration to original plant dynamics, due to its prolific seed production. Neglecting to control invasive species such as garlic mustard could result in a decrease in biodiversity and an interruption of ecosystem function (Myers 1997; Mooney and Hobbs 2000; Sala et al. 2000).

Although some skeptics assert that invasive species are not a threat to biodiversity (Gattuso 2006), most scientists assert that invasive species are indeed changing environmental conditions in undesirable ways (Myers 1997; Mooney and Hobbs 2000; Sala et al. 2000). Harmful effects of invasive species include interruption of natural ecosystem function and disturbance regimes, decreasing global biodiversity, genetic pollution through hybridization, and reduction in yield of crops. NASA names non-native invasive species as the "single most formidable threat of natural disaster of the twenty-first century" (Soukup 2005). Meanwhile, the National Park Service, charged with preserving America's natural resources, asserts that invasive species are "one of the greatest threats to our natural and cultural heritage” (Schnase 2005).

There are more than 30 federal laws concerning biological invasions and numerous state laws to govern the transportation and introduction of invaders, but those laws are difficult to enforce (Freeman et al. 2009). In 1974, the Federal Noxious Weed Act restricted the introduction and spread of non-native plants. The National Invasive Species Council (NISC) was formed in 2001 to provide a center to spearhead invasive species management (Freeman et al. 2009). Many U.S. states have their own lists of invasive plants as well as their own quarantine and control laws. For example, the Plant 
Protection Act of 2000 restricted the transportation or importation of plants, plant products, biological control organisms, noxious weeds, and plant pests (United States Congress 2000). Violations of the Plant Protection Act are subject to harsh civil penalties ranging from $\$ 1,000$ to $\$ 50,000$ for individual offenders and from $\$ 250,000$ to $\$ 500,000$ for group violations (United States Department of Agriculture 2002).

Laws concerning invasive species are not only difficult to enforce, but are often found by the average citizen to be unimportant. Incidences of implementation of civil penalties are difficult to find evidence of. Certain states have also implemented their own legal codes in regards to the Plant Protection Act; for example, New Mexico only prosecutes those violators of the Plant Protection Act that continue their actions after being served a cease-and-desist order (New Mexico Department of Agriculture 2006). Those who continue to violate the order are tried and if convicted, are considered guilty of a petty misdemeanor instead of having to pay a hefty fine (New Mexico Department of Agriculture 2006). These laws are difficult to enforce due to inadequate manpower, many countries have begun using codes of conduct on a voluntary basis to control new species introductions (Reaser et al. 2003). In a protected area visited by tourists throughout the year, it is difficult to determine fault for invasive plant introduction, so parks are forced to control the effects of introduction without the ability to hold any party responsible.

Policy makers need current scientific and technical information to continue developing effective strategies for invasive species regulation. Unfortunately, most countries do not have an inventorying or monitoring system for invasive plants (Reaser et al. 2003). If inventory and monitoring data does exist for a country, it is often scattered between locations and databases. The available data also has different 
management goals associated with them and are often not available to the public (Ricciardi et al. 2000; Wittenberg and Cock 2001). This is true for Pictured Rocks National Lakeshore: they have fairly extensive and accurate data for a park unit; however, their data is not part of a national database and is therefore not readily available to the public.

Continuing investment from government and private sectors in invasive plant management is needed. One of the most pressing needs is for funding to manage invasive species (Freeman et al. 2009). Finding funding is politically improbable, since sources and amounts are sparse. The average American does not understand the urgency of invasion ecology in natural systems and therefore the attempts to protect natural systems are often ineffective (Freeman et al. 2009). Ultimately, a country's capacity to address the problems caused by invasive species depends on the willingness of its government to enforce and fund invasive species legislation and research (Reaser et al. 2003).

\section{National Park Service Policy}

Attempts to control non-native plants in National Parks began in the 1970s with the NPS's 3-volume administrative policy document (Dennis 1999). Early National Park Service (NPS) policy focused on non-native species introduced into National Parks and the possible consequences of those (National Park Service 1988). Control methods have evolved over time from widespread use of herbicides to large-scale mechanical treatments (Dennis 1999). Current National Park Service policy states that the control of introduced species can include "up to and including eradication...whenever such species threaten park resources...[and] high priority will be given to [introduced species] that have a substantial impact on park resources” (National Park Service 1988). 
Current management practices outlined in the National Park Service document Management Practices include preserving native species populations while controlling non-native species (National Park Service 2006). Non-native species are not considered a natural component of the natural systems in National Parks (National Park Service 2006). Management is allowed conditionally, including when it is needed to protect rare or threatened species (National Park Service 2006). Before aggressive management techniques such as herbicide application are undertaken, the park is required to "ensure that such removals will not cause unacceptable impacts on native resources, natural processes, or other park resources" (National Park Service 2006).

In the official Management Practices document of the National Park Service, the policies for invasive plant control are stated clearly. In regards to invasive species, the document states that "exotic species will not be allowed to displace native species if displacement can be prevented" (National Park Service 2006). The manual also states that all non-native plants in a park that are not serving a purpose defined by the park (e.g. restoration) must be managed if control is feasible (National Park Service 2006). High priority is given to invasive plants that have or could have a significant impact on vegetation in a park (e.g. garlic mustard or spotted knapweed in Pictured Rocks National Lakeshore). Non-native species that do not have a significant impact on vegetation are a lower priority. If an invading population cannot be eradicated, the plant must be contained to prevent spread and further ecosystem damage (National Park Service 2006).

National Parks do not have sufficient funding to manage every resource they protect. During the fiscal year 2006, National Parks in Michigan were appropriated funding from the federal government in the amount of $\$ 10.5$ million (National Park 
Conservation Association 2011). The 2008 fiscal year saw an increase to $\$ 12$ million for operations across all National Parks in Michigan (National Park Conservation Association 2011). Monies appropriated to the National Park Service increased from 2001 to 2005 (Nazzaro 2006). The total budget for the National Park Service for the fiscal year 2011 totaled $\$ 2.75$ billion, but current proposed budget cuts total approximately $\$ 100$ million (Repanshek 2011). There is currently a maintenance backlog across the agency totaling nearly $\$ 11$ billion (Repanshek 2011). While some maintain that the most frequented National Parks should be self-sufficient based on their collected fees (Regan 2011), National Parks tend to "bank" their entrance fees towards large and expensive projects when they can (Repanshek 2010), especially with the maintenance backlog across the agency. However, some National Parks (such as Pictured Rocks National Lakeshore) do not charge a user fee and instead charges only for campsites, so the option of banking user fees is null.

Overall, the National Park Service has policies in place regarding the establishment and control of invasive species, but funding is often inadequate for control of invasive species and restoration of affected ecosystems. Policies on invasive species are implemented differently between park units. In the case of Pictured Rocks National Lakeshore, the war against invasive plants is an uphill battle.

\section{History of Pictured Rocks National Lakeshore}

Pictured Rocks National Lakeshore has a long history of anthropogenic influence. Before European settlement, "The Pictured Rocks” were part of Ojibwa land (Gordon 1881). The tribe believed that the landforms were shaped by unseen spirits, causing them to use the land solely as a burial site and hunting and gathering grounds (Gordon 1881). European settlers were first documented in the area in 1658 (Karamanski 1995). Fur 
traders were awed by the beauty of the colored cliffs and sand dunes, but due to its remote location and harsh climate, the area was not settled until the mid-18oos. Missionaries and explorers followed fur traders to the area and established the first European settlements (Gordon 1881). Iron mining began in the Upper Peninsula in the mid-180os, which caused massive amounts of timber harvesting for charcoal production (National Park Service 2009). Timber harvesting continued in the park area until it was established as a National Lakeshore and continues today in the Inland Buffer Zone (IBZ), an area established as a buffer between the park and the rest of the Upper Peninsula.

The purpose of establishing Pictured Rocks National Lakeshore was to protect the natural processes of a rare ecosystem for aesthetics and usefulness while providing recreation. The shorelines of the Great Lakes were surveyed in 1957 and 1958 for suitable shoreline to be included in the National Park Service. Out of approximately 5,500 total miles of shoreline, 118 miles of mostly federal and state landholdings were identified for possible inclusion (Petersen 1986). Of that, Pictured Rocks comprised 43 miles (Great Lakes Survey 1959). Pictured Rocks National Lakeshore was signed into existence in 1966, hence becoming the first National Lakeshore in America (Petersen 1986).

Pictured Rocks National Lakeshore was controversial to locals in its inception stage. It was originally intended to be more than 40,000 hectares in size with a scenic shoreline drive, but locals voiced concerns that a park that size would occupy too much timber land (Petersen 1986). By the time the park was created in 1966, the area was 28,893 hectares split into two zones: the shoreline zone and the IBZ. The shoreline zone is solely under the ownership of the NPS while the IBZ is under mixed but guided ownership. The purpose of the IBZ is to create a buffer that will protect the shoreline zone from the effects of management outside the park (Petersen 1986). There are 
restrictions on resource management within the IBZ so that the management activities in that area have a minimal effect on the shoreline zone (Petersen 1986). For example, sustainable logging practices are enforced in the IBZ to protect the watershed within the park.

National Lakeshores in the National Park System are oddities and generally a source of contention (Karamanski 1995). The lakeshore projects of the National Park Service had magnified expectations at their inceptions and Pictured Rocks National Lakeshore in particular faced problems due to its location and politics (Petersen 1986). The original legislation establishing the Lakeshore included a proposed scenic shoreline drive that was seen as a solution to the small local economy (Karamanski 1995). The scenic drive was a source of contention between parties that valued recreation areas and parties that valued local economic stimuli (Petersen 1986). However, a park can grow and change in response to the needs of the public according to the NPS legislative mandate (Winks 1997), and so the scenic lakeshore drive was abandoned in favor of protecting the lakeshore resources.

The ecological history of Pictured Rocks National Lakeshore is unique in the Upper Peninsula of Michigan. The Lakeshore has been shaped over geologic time to lie on sedimentary bedrock that is mostly composed of sandstone (National Park Service 2011). Rare geologic features within the park include picturesque sandstone cliffs and lacustrine sand dunes, which are the main features viewed at the park (NPS 2011).

The distribution and composition of vegetation in the park is largely controlled by geomorphology, hydrology, and disturbance regimes (Bach 1978; National Park Service 2011). There are currently nineteen different vegetation types within the park 
and the IBZ, including ten different forested habitat types and two different open sand habitat types (National Park Service unpublished data).

There are a number of rare and threatened species throughout the park, including the federally threatened Pitcher's thistle (Cirsium pitcher Torr. ex Eaton) and Lake Huron tansy (Tanacetum huronense L.), a threatened species in the state of Michigan (Read 1975; Bach 1978; National Park Service unpublished data). The dune ecosystem in particular is home to a great number of rare and endangered plants, including moonworts (Botrychium spp. L.), ram's head lady's-slipper (Cypripedium arietinum W.T. Aiton), and dune stitchwort (Stellaria longipes L.).

The composition vegetation within the park is continually changing, although at different rates. Most of the forests were logged before 1966 and the IBZ continues to be sustainably logged (National Park Service 2011). With an increase of traffic to the area, more non-native species have been introduced. Of the approximately 767 species in the park, 127 (approximately 17\%) are non-native (National Park Service unpublished data), so invasive species are a significant concern at Pictured Rocks National Lakeshore.

\section{Invasive Species in Pictured Rocks National Lakeshore}

Invasive species are a widespread problem throughout the National Park Service. In 2000, an estimated 1 million hectares of National Parks were occupied by invasive plants, which was approximately $5 \%$ of agency land holdings (Dollemore 2005). In response, the National Park Service Exotic Plant Management Teams (EPMT) were formed. Working in 189 of a total of 394 park units, the teams have treated over 20,000 hectares between 2000 and 2008 with mechanical, chemical, and burning methods (Dollemore 2005). The Great Lakes EPMT services eight parks in the Great Lakes region, 
including Pictured Rocks. The park also allocates annual funding for its own exotic plant team that surveys the park during the field season, locates new invasive plant introductions, maps the size and density of existing population, and implements control methods as needed.

Research shows that invasive plants spread due to life history traits that enable them to outcompete native vegetation, which can be especially detrimental in protected areas (Vitousek et al. 1996; Myers and Bazely 2003; Radosevich et al. 2007; Marshall et al. 2008). Not only do the park boundaries of Pictured Rocks National Lakeshore contain the only active lacustrine sand dunes on Lake Superior, but the park is also the only location that Pitcher's thistle is found in some abundance on Lake Superior (NPS 2011). Due to the rare plant communities present within the park, personnel have been particularly diligent about mapping the vegetation and Pictured Rocks therefore has an excellent database of geographic information system layers.

Non-native plants were first documented as a threat to park biodiversity in 1981 (Leutscher and Bruff 2008). Undirected control efforts in the park vicinity were undertaken around that same time (Grzesiak personal communication 2010). Spotted knapweed seems to be the first plant targeted for control in the park area, and many areas seem to have high instances of introduction of many invasive plants. For example, the Miner's Castle area of the park currently has populations of garlic mustard, reed canarygrass (Phalaris arundinacea L.), spotted knapweed, and forget-me-not (Myosotis L.) that were introduced directly into that area probably due to high traffic.

The IBZ of Pictured Rocks National Lakeshore presents a unique management problem for the park. The IBZ is an area of National and State Forest land and private forest holdings interspersed with small private parcels. The zone represents a problem 
for the park because the park cannot control invasive plants on private land, nor do they have jurisdiction to do so in adjoining National Forests or State Forests (Leutscher personal communication 2008). On the other hand, the IBZ is a useful management tool for the hydrology of the park since they enforce sustainable logging practices within its boundaries.

As part of the National Park Service's Centennial Initiative launched in 2006 to prepare National Parks for another century of conservation, Pictured Rocks National Lakeshore identified improving the monitoring of the condition of the park's natural ecology and cultural resources as a major goal (Bomar 2007). This goal included monitoring and controlling invasive species invasive species in a timely manner to protect park resources for the future (National Parks Conservation Association 2008). The NPS is also implementing their Inventory and Monitoring (I\&M) Program to "improve park management through greater reliance on scientific knowledge" (Inventory and Monitoring Program 2010). The goals of the I\&M Program include inventorying, monitoring, and mapping natural resources and in effect, invasive species, so it will provide a more accurate idea of how invaded areas of the park are.

Management of invasive plant species is a high priority at Pictured Rocks National Lakeshore, even though control of non-native species is a single goal in a wide set of management goals (National Parks Conservation Association 2007). The park has a program in place to contain invasive plants and a system for monitoring the success of this program. By periodically mapping invasive plant coverage within the Grand Sable Dunes, teams of 5-10 seasonal park staff can map and track changes. Locations of plant introductions are recorded via GPS for park information. Using this data, multi-criteria risk assessment models have been built and tested for the park for eight invasive species. 
Over the past decade, the park has provided funding for graduate students from Michigan Technological University and Northern Michigan University have been hired to implement cooperative projects focusing on plants in the dune ecosystem.

Pictured Rocks National Lakeshore has utilized many methods of invasive plant control (NPS 2006). Physical pulling and spraying herbicide are the commonly utilized control methods in the park. Many invasive species have spread due to inadequate resources for control within the park. An extensive 3-year program began in 2008 to map and control invasive plants (Grzesiak personal communication 2010). Park staff has pulled, mowed, and sprayed exotics throughout the park. Continuous control of invasive plant populations is required or populations may re-establish.

The park has joined forces with other federal and state organizations to form the Upper Peninsula Invasive Species Council (National Parks Conservation Association 2007). The council wanted to create stronger cooperation between organizations to focus efforts on controlling invasive species (LeBlanc 2008). The group wanted to establish certified weed management areas to increase invasive species awareness. This goal was met in 2008 with the creation of the Central Upper Peninsula Certified Weed Management Area, where volunteers work to remove and map exotic plants in Alger, Delta, Marquette, and Schoolcraft counties.

Due to the park's thorough vegetation mapping, they are able to monitor some invasive plant populations within the park and identify populations of invasive plants that should be controlled. The first official documentation of vegetation in the park occurred in the mid-1970s and exotic plants were documented within the park at that time (Read 1975). Another documentation of exotic plants within the park occurred in the early 1980 s (Leutscher and Bruff 2008). There were at least 127 non-native species 
present in the park in 2006, which is approximately $16 \%$ of all known plant species at Pictured Rocks National Lakeshore (Leutscher and Bruff 2008).

The Research Natural Area (RNA), a part of a national network of areas reserved for ecological research and education, was formed in 1994 and consists of 740 hectares in the Grand Sable Dunes (National Parks Conservation Association 2007). Many federal agencies establish RNAs to encompass areas that have unique characteristics so that those unique natural features can be explored by scientists (National Parks Conservation Association 2007). At Pictured Rocks, the RNA provides opportunities for the park and scientists alike to observe and quantify the effects of invasive species control. In the last decade, Michigan Technological University has conducted research studies quantifying the insect populations and plant dynamics in areas invaded by spotted knapweed (Marshall et al. 2008; Latsch et al. unpublished data). Other research projects in the Research Natural Area of Pictured Rocks National Lakeshore include mapping of Pitcher's thistle habitat, researching habitat types of native orchid species, small mammal trapping and habitat analysis, research on rare moonwort habitat, and mapping of all vegetation types (Bozic unpublished data; Hardenbrook unpublished data; Malick unpublished data).

Most of the invasive plants being monitored by the park are terrestrial species. Over 120 hectares of the lacustrine dunes on Lake Superior are invaded with spotted knapweed and red clover (Trifolium pretense L.). Other invasive plants that the park is concerned about include baby's breath (Gypsophila paniculata L.), garlic mustard (Alliaria petiolata M. Bieb.), bishop’s goutweed (Aegopodium podagraria L.), Japanese knotweed (Polygonum cuspidatum Siebold \& Zucc.), and purple loosestrife (Lythrum salicaria L.). Since the park boundary extends 0.25 miles into Lake Superior, 
encroaching aquatic invasive species could become more of an issue in the near future. Monitoring for exotic plants is a continuing task for the park in the hopes of detecting invasions before they become established.

The park has recently identified the usefulness of multi-criteria risk assessment models as a management tool. They currently have models for eight plant species and can monitor areas most at risk of introduction, establishment, and spread within the park (Latsch et al. unpublished data). Pictured Rocks has found that multi-criteria risk assessment models for eight of their most ecologically damaging plants are useful for directing its limited resources. Other multi-criteria risk models have been built for other parks in the Great Lakes Network of National Parks and for other scattered governmental management areas across the nation. However, the Lakeshore is a leader in utilizing those early detection tools in that it continually updates the models so that they models continue to be current and useful.

Pictured Rocks National Lakeshore has numerous invasive plants on which they focus their management efforts. The eight multi-criteria risk assessment models built for the park focused only on the plants the park considered the most ecologically damaging. Currently, the park actively controls and monitors more than fifteen invasive plants.

Spotted knapweed has extensively invaded the Lakeshore (National Park Service 2010). The plant can quickly populate dry and disturbed habitats, making the sandy soil of the park a perfect substrate, making spotted knapweed a high priority for control in the dunes (United States Department of Agriculture 2011). Control efforts in the park began at Sand Point with mechanical pulling efforts (Grzesiak personal communication 2010). In the Grand Sable Dunes, intensive and sustained herbicide treatments are required. Due to the highly invasive nature of spotted knapweed, more than 120 hectares 
of the dunes have been invaded, and resources are not adequate for control of that area. An ongoing herbicide project in the RNA was implemented in order to give the park a more accurate idea of the budget and personnel that would be required to control spotted knapweed in that habitat. Overall, the current status of spotted knapweed is monitored, but not successfully controlled.

Forget-me-not is another species extensively invading the park. This plant is aesthetically pleasing due to its light blue or pink flower. The plant was not controlled early in the park and so has spread to large areas, including the forest understory. Pulling and spraying has been generally ineffective on populations in the park (Grzesiak personal communication 2010). Forget-me-not ranks highly in the park for control due to its propensity to spread quickly and outcompete native vegetation under canopy cover, including the native violets in the park.

Purple loosestrife has previously been found in the park, but is not currently documented. In the early-to mid-1990s, a single purple loosestrife plant was found in two separate locations: the Mosquito River Trail and the Little River boat ramp. Since this plant can quickly overtake wetlands and dominate vegetation, the plants were quickly removed. Due to the abundance of small wetlands in Pictured Rocks National Lakeshore, monitoring for this plant is difficult.

Other invasive species that have been controlled in the park include baby's breath and wild parsnip. Baby's breath would be detrimental if it was allowed to establish in the dunes. This plant had previously been introduced in the dunes, but was detected early and was aggressively controlled (Grzesiak personal communication 2010). The area of introduction is currently being monitored for resurgence. A recent introduction of wild parsnip (Pastinaca sativa L.) at Miner's Beach provoked immediate management due to 
that plant's threat to human health with its sap that causes chemical burns on skin when exposed to sunlight (Grzesiak 2010).

Glossy buckthorn and leafy spurge are plants that have not been introduced to the park but are being monitored for (Grzesiak personal communication 2010). These two invasive plants would be high priority plants if they were introduced due to their tendency to displace native species and create monocultures.

Garlic mustard seems to be the most well-controlled plant in the park (Grzesiak personal communication 2010). This plant is a high priority to the park due to its tendency to displace native plants. Since its introduction to the Miner's Castle area in 2008 , the plant has been continually pulled and sprayed. The population is not spreading, so the park has currently labeled this plant controlled.

Other species the park has been controlling but are not of high priority include periwinkle, common tansy, red clover, white sweet clover, mullein, St. John's wort, and hawkweed. These species are not considered to be ecologically damaging in the park to the point that a full-scale control program needs to be implemented.

Invasive species are a continuing concern and expense for Pictured Rocks National Lakeshore. Some plants, if not aggressively controlled, could change the plant communities that the park was established to protect. These invasive plants could alter ecosystems to the point that they could not be restored if the plants were eradicated. The park's proactive approach is ideal for invasive plant management; however, their efforts are, as always, limited by available resources. 


\section{Summary}

Pictured Rocks National Lakeshore and their battle against invasive plants is an example of a management unit asked to perform a huge task with limited resources. The park has limited funds and so generally cannot afford to pursue or use traditional control programs. They are therefore using the funds they are allocated to control the plants that will be most detrimental to the natural resources of the park while also investing their funds in tools, like the multi-criteria risk models, that will help them in long-term management programs. Overall, Pictured Rocks National Lakeshore can be seen as an example to smaller, less visited National Parks wishing to develop proactive approaches to invasive species control.

\section{Literature Cited}

Bach, David P. 1978. Plant communities, habitats, and soil conditions of Grand Sable Dunes, Pictured Rocks National Lakeshore, Michigan. M.S. Thesis. Houghton, Michigan: Michigan Technological University. 180 p.

Bomar, M.A. 2007. NPS Centennial Initiative Program: Centennial strategy for Pictured Rocks National Lakeshore.

Dennis, J.G. 1999. National Park Service Management Policies for the National Park System. The George Wright FORUM 16(3): 7-18.

Dollemore, D. 2005. Controlling the spread of invasive plants: a national effort. Science Blog. www.scienceblog.com. Accessed: August 2005.

Freeman, J.E., R. Albritton, S. Jose, and J.R.R. Alavalapati. 2009. The economics, law, and policy of invasive species management in the United States: responding to a growing crisis. Pp. 409-426 in R. Kohli, S. Jose, H.P. Singh, D.R. Batish, eds. Invasive Plants and Forest Ecosystems. Boca Raton, Florida: CRC Press.

Gattuso, D.J. 2006. Invasive species: animal, vegetable, or political? National Policy Analysis. 544 .

Great Lakes Shoreline Recreation Area Survey. 1959. Remaining Shoreline Opportunities in Minnesota, Wisconsin, Illinois, Indiana, Ohio, Michigan, Pennsylvania, New York. United States Department of the Interior. 
Gordon, H.L. 1881. Legends of the Northwest including 'The Sea Gull': The Ojibwa Legend of the Pictured Rocks of Lake Superior. St. Paul, MN: St. Paul Book and Stationery Co. 143 p.

Grzesiak, K. 2010. Pictured Rocks National Lakeshore Exotic Plant Management Team Handbook.

Inventory and Monitoring Program. 2010. National Park Service. http://science.nature.nps.gov/im/index.cfm. Accessed: April 2010.

Karamanski, T.J. 1995. The Pictured Rocks: An Administrative History of Pictured Rocks National Lakeshore. United States Department of the Interior.

Kareiva, P., S. Watts, R. McDonald, and T. Boucher. 2007. Domesticated nature: shaping landscapes and ecosystems for human welfare. Science 316 (5833): 1866-1869.

LeBlanc, D. 2008. Certified weed management area formalized for the central Upper Peninsula of Michigan. USFS Success Stories.

Leutscher, B. and G. Bruff. Pictured Rocks news. June 19, 2008. www.nps.gov/piro/parknews/control-invasives.htm. Accessed April 2010.

Marshall, J.M., A.J. Storer, and B. Leutscher. 2008. Comparative analysis of plant and ground dwelling arthropod communities in lacustrine dune areas with and without Centaurea biebersteinii (Asteraceae). The American Midland Naturalist 159(2):261-274.

McNeely, J.A., H.A. Mooney, L.E. Neville, P.J. Schei, and J.K. Waage, eds. 2001. Global Strategy on Invasive Alien Species. Cambridge: IUCN in collaboration with the Global Invasive Species Programme.

Mooney, H.A. and R.J. Hobbs. 2000. Invasive species in a changing world. Washington, D.C.: Island Press. 457 p.

Myers, N. 1997. Global biodiversity II: losses and threats. Pp. 123-158 in G.K. Meffe and C.R. Carroll, eds. Principles of Conservation Biology, $2^{\text {nd }}$ edition. Sunderland, Massachusetts: Sinauer.

Nazzaro, R.M. 2006. Major operations funding trends and how selected park units responded to those trends for the fiscal years 2001 through 2005. Statement For The Record: National Resources and Environment. US Government Accountability Office. 26 p.

National Invasive Species Council. 2001. Meeting the invasive species challenge: National Invasive Species management plan. Washington, D.C. 
National Park Conservation Association. 2007. State of the Parks: Pictured Rocks National Lakeshore. Pp 6-24.

National Parks Conservation Association. 2008. National Parks in Michgan. http://www.npca.org/nationalpriority/pdf/MI-FS.pdf. Accessed: April 2011.

National Park Service. 1988. Management Policies Washington, D.C. US Government Printing Office.

National Park Service. 2006. Management Policies 2006. Washington, D.C. US Government Printing Office.

National Park Service. 2009. Decreasing effectiveness of protected areas due to increasing development in the surroundings of U.S. National Park Service holdings after park establishments. Natural Resource Technical Report 178. 20 p.

National Park Service. 2010. Nonnative Species of Pictured Rocks National Lakeshore. 2010. National Park Service Website. Accessed: April 2010.

National Park Service. 2011. Natural features and ecosystems of Pictured Rocks National Lakeshore. http://www.nps.gov/piro. Accessed: March 2011.

New Mexico Department of Agriculture. 2006. New Mexico Territorial Laws: Plant Protection Act. Chapter 76, Article 5: Insect Pests and Plant Diseases.

Petersen, G. 1986. Pictured Rocks National Lakeshore: an American first. Pp. 251-253 in C. Symon, ed. Alger County: A Centennial History, 1885-1985. Alger County Historical Society, Munising, Michigan.

Pimental, D., R. Zuniga, and D. Morrison. 2005. Update on the environmental and economic costs associated with alien-invasive species in the United States. Ecological Economics 52(3): 273-288.

Read, R.H. 1975. Vascular plants of Pictured Rocks National Lakeshore, Alger County, Michigan. The Michigan Botanist 14(1): 3-43.

Reaser, J.K., B.B. Yeager, P.R. Phifer, A.K. Hancock, and A.T. Gutierrez. 2003. Environmental diplomacy and the global movement of invasive alien species: a US perspective. Pp. 362-381 in G.M. Ruiz and J.T. Carlton, eds. Invasive Species: Vectors and Management Strategies. Washington, D.C.: Island Press.

Regan, S. 2011. The most visited National Parks could be self sufficient. High Country News January 20, 2011.

Repanshek, K. 2010. Entrance fees generate hundreds of millions of dollars a year for National Park Service. National Parks Traveler February 2010. 
Repanshek, K. 2011. Congress slashes $\$ 101$ million from National Park Service budget. National Parks Traveler March 2011.

Ricciardi, A., W.W.M. Steiner, R.N. Mack, and D. Simberloff. 2000. Towards a global information system for invasive species. BioScience 50: 239-244.

Sala, O.E., F.S. Chapin III, J.J. Armesto, E. Berlow, J. Bloomfield, R. Dirzo, E. HuberSanwald, L.F. Huenneke, R.B. Jackson, A. Kinzig, R. Leemans, D.M. Lodge, H.A. Mooney, M. Oesterheld, N.L. Poff, M.T. Sykes, B.H. Walker, M. Walker, and D.H. Hall. 2000. Global biodiversity scenarios for the year 2100. Science 287: 17701774 .

Schnase, J.L. 2005. Invasive Species: An emerging science application for geospatial information. Pp. xiii-xviii in P. Agouris and A. Croitoru, eds. Next Generation Geospatial Information: From Digital Image Analysis to Spatio-temporal Databases. London: Taylor and Francis Group.

Soukup, M. 2005. Invasive Species: Scientists Demand Action on Invasive Species. Invasive Species Management, Program Plan: 2003-2007, NASA, Office of Earth Science, Applications Program, June 6, 2003.

Stohlgren, T.J., D. Barnett, C. Flather, P. Fuller, B. Peterjohn, and J. Kartesz. 2006. Species richness and patterns of invasion in plants, birds, and fishes in the United States. Biological Invasions 8:427-457.

United States Department of Agriculture. 2002. Plant Protection and Quarantine: The Plant Protection Act. APHIS Factsheet. http://www.aphis.usda.gov/lpa/pubs/fsheet_faq_notice/fs_phproact.pdf. Accessed: April 2011.

United States Department of Agriculture, NRCS. 2011. The PLANTS Database (http://plants.usda.gov, 19 March 2011). National Plant Data Center, Baton Rouge, LA, USA.

United States. Congress. House. Committee on Agriculture. Subcommittee on Department Operations, Nutrition, and Foreign Agriculture. 2000. Plant protection act. U.S. Department of Agriculture, Animal and Plant Health Inspection Service web site: http://www.aphis.usda.gov/ppq/weeds/PPAText.PDF. Accessed: December 12, 2010.

Vitousek, P.M., C.M. D’Antonio, L.L. Loope, and R. Westbrooks. 1996. Biological invasions as global environmental change. Conservation and Ecosystem Management. Pp 218-228. 
Vitousek, P.M., H.A. Mooney, J. Lubchenco, and J.M. Melillo. 1997. Human domination of Earth's ecosystems. Science 277: 494-499.

Westbrooks, R.G., W.P. Gregg, and R.E. Eplee. 2001. My view. Weed Science 49: 303304 .

Wilcover, D.S., D. Rothstein, J. Dubow, A. Phillips, and E. Losos. Quantifying threats to imperiled species in the United States, Bioscience 48(8) 607-615.

Winks, R.W. 1997. The National Park Service Act of 1916: "A Contradictory Mandate?" Denver University Library Review. 575 p.

Wittenberg, R. and M.J.W. Cock. 2001. Invasive Alien Species: A Toolkit for Best Prevention and Management Practices. Oxon: CAB International. 


\title{
CHAPTER 3
}

\section{MULTI-CRITERIA RISK ASSESSMENT MODELS \\ FOR INVASIVE PLANTS \\ IN PICTURED ROCKS NATIONAL LAKESHORE: DEVELOPMENT, VALIDATION, AND IMPLEMENTATION}

\begin{abstract}
Invasive species are threatening the diverse habitats within Pictured Rocks National Lakeshore in the Upper Peninsula of Michigan. The invasive exotics burdock (Arctium minus), bishop's goutweed (Aegopodium podgraria), forget-me-not (Myosotis spp.), garlic mustard (Alliaria petiolata), periwinkle (Vinca spp.), red clover (Trifolium pratense), spotted knapweed (Centaurea maculosa), and sweet clover (Melilotus spp.) have the ability to alter ecosystems and are invading significant acreage within the park. Management of these plants is therefore a high priority for the park. Multi-criteria risk models were developed and tested for those eight species by assigning risks to GIS layers such as vegetation, soils, and hydrology. The average overall accuracy of the introduction phase of invasion was $89.5 \%$, while the establishment phase tested at $93.4 \%$ accuracy, and the spread phase tested at $91.6 \%$ accuracy. The predictive models can be the first step to a proactive approach to invasive plant management that includes locating and eradicating the population of a given invasive plant before it becomes established and spreads.
\end{abstract}




\section{Introduction}

Ecological risk assessment is the probability of a specific effect occurring in an ecological system. In invasion ecology, that could be the probability of the introduction, establishment, or spread of an invasive species. Effective risk assessment requires information about the environmental characteristics of a site, biological characteristics and impacts of the invading plant, and known locations of the invasive plants (Radosevich et al. 2007). Information on specific invasive plant life history traits and management practices allows landowners to manage plant populations and communities to meet specific management goals (Monaco et al. 2002). For example, knowing that a species does not grow above a certain altitude could give a land manager opportunity to use a geographic barrier to eradicate an invasive plant instead of using other costly management techniques. Prickly pear cactus (Opuntia ficus-indica) is an example of a species that has been controlled in South Africa using geographic barriers (Mooney and Hobbs 2000). Using life history traits to predict areas at risk are not only useful for species already identified as invasive, but can be useful for identifying plants that may become invasive if they are introduced (Mack 1996; Reichard and Hamilton 1997; Goodwin et al. 1999; Rejmanek 2000; Pyšek et al. 2004).

Most current invasive plant management programs focus on detection and eradication of invasive plants already established in an area (Radosevich et al. 2007). Efforts to control existing invasive plant populations are important, but they are often time consuming and expensive. Much effort is currently being directed towards researching novel and more environmentally friendly tools for controlling invasive species. Predictive modeling is one such area of research (Monaco et al. 2002). Risk modeling offers the prospect of being able to focus management on areas where it will have the greatest impact in terms of altering the trajectory of ongoing invasive plant 
invasions. Prevention is the most economical and practical approach to controlling invasive plants (Kolar and Lodge 2001). Predicting invasiveness of a nonindigenous species has appeal to ecologists; however, a more practical approach seems to be assessing risk (National Research Council 2002). A high level of uncertainty accompanies prediction of a plant's invasiveness due to the plant not exhibiting invasive characteristics in its native habitat (David et al. 2000; Cizek et al. 2004). Therefore, risk assessment is a viable option for accurately assessing areas at risk for introduction, establishment, or spread of invasive plants. Predictive risk modeling can be a useful tool in predicting areas a plant may be introduced and establish; however, models need to be practical in order to be useful to land managers.

Prevention, early detection, or containment of newly introduced species are less damaging to ecosystems and less costly over time, but are often given lower priority than managing large-scale, damaging invasions. Although it may be one of the most efficient control methods, early detection is a low-probability event that depends on adequate surveillance (Holcombe and Stohlgren 2009) to which the park may not have access. Predicting areas most at risk for invasion of certain plants can ultimately save land managers both time and money by allowing more targeted surveillance efforts.

Preventing species from being introduced seems like a straight-forward approach to invasive plant management. However, the process of identifying potential invaders prior to invasion is difficult and costly. Early detection is currently the best tool available to land managers for ensuring invasive plant populations can be controlled at an early stage of invasion (Lockwood et al. 2001; Underwood et al. 2004). Early detection of invasive plants in large and remote areas can be inefficient and costly (Radosevich et al. 2007) and is therefore often unachievable. Predictive models can be the first step to a proactive approach to weed management that includes locating and eradicating the 
population of a given invasive plant before it becomes established and spreads (Stohlgren and Schnase 2006).

Multi-criteria risk assessment modeling is the compilation of GIS data to predict the risk of invasion in a given habitat (Jager and Overton 1993). It is a form of risk assessment and can be useful to land managers in a multitude of ways. Not only can the models be used as a predictor of spatial patterns as we have done in this study, but can also predict viable habitat for animal populations or predict survey variables for natural resources (Jager and Overton 1993).

The introduction stage of invasion occurs when a plant not native to an area is introduced (Cousens and Mortimer 1995; National Research Council 2002). Introduction of plants is most dependent on habitat, growth form, seed type, and life cycle (Monaco et al. 2002; Myers and Bazely 2003; Theoharides and Dukes 2007). Therefore, the introduction stage of the models includes disturbance, vegetation, dispersal, and soil layers. The establishment phase of invasion is achieved when the plants have established a surviving population that is not yet widespread or rapidly expanding (Groves 1999; National Research Council 2002; Groves 2006). Establishment depends largely on light, temperature, water availability, wind, soil, topography, and competition with other plants (Monaco et al. 2002; Theoharides and Dukes 2007). The establishment stage of the models therefore includes disturbance, vegetation, soil, and introduction layers. The spread phase of invasion is achieved when the population is rapidly expanding and dispersing to new areas (National Research Council 2002; Colautti and MacIsaac 2004). Soil, climate, disturbance, dispersal, and habitat connectivity are the factors most responsible for spread of invasive plants (Mooney and Hobbs 2000; Rejamanek 2000; Radosevich et al. 2007; Theoharides and Dukes 2007). The spread stage of the GIS risk assessment models therefore includes disturbance, 
dispersal, establishment, EPMT delineations, and connectivity layers. Plants with life history traits dissimilar to native vegetation are often most successful at invasion.

There is a continuing need for tools to accurately assess the present and future impacts of invasive plants so that land managers can justify the resources needed to control the plants (Radosevich et al. 2007). This is especially important in nonagricultural natural areas like units in the National Park Service, where no direct economic benefit resulting from the control of invasive species can be clearly shown. For example, invasions of agricultural systems can be subjected to a cost-benefit analysis to give an accurate estimate of losses due to invasion of control of weeds (Radosevich $\mathrm{et} \mathrm{al}$. 2007), but invasions of flowering invasive plants in recreation areas are not easily quantifiable. Therefore, multi-criteria risk models can be useful tools for land managers to assess the extent to which habitats are at risk of invasion.

The National Park Service is charged with conserving the natural, historic, and cultural assets of protected land areas in the United States for the enjoyment of future generations (National Park Service 2010). The National Park Service protects not only areas designated as National Parks, but also areas designated by Congress as National Lakeshores, National Monuments, and National Historical Sites (National Park Service 2011a). Pictured Rocks National Lakeshore is one of four National Lakeshores in the country and one of two located adjacent to Lake Superior (National Park Service 2011a). The National Park Service has limited funding and man power for the management of invasive plants and is therefore an ideal candidate for the production of multi-criteria risk assessment models to help guide management efforts.

Pictured Rocks National Lakeshore is located in Alger County in the Upper Peninsula of Michigan. The Lakeshore protects 42 miles of the southern Lake Superior 
shoreline (National Park Service 2011b). The park occupies 29,637 hectares that include unique sandstone cliffs and active lacustrine sand dunes (National Park Service 2011a). It is the only National Park Service land holding whose boundaries include an inland buffer zone (IBZ), which is owned by the State of Michigan, corporations, and private citizens (National Park Service 2011b). The IBZ was established to permit timber harvesting while protecting the watershed (National Park Service 2011b).

GIS risk assessment models developed for Pictured Rocks National Lakeshore determine risk for the introduction, establishment, and spread invasion stages of eight invasive plants. Two of the models (spotted knapweed and garlic mustard) were previously developed for Pictured Rocks National Lakeshore (Shartell 2007). The other six models were developed especially for the park. For each stage of invasion, risks were assigned to GIS layers based on the habitat requirements of each invasive plant. Each stage of invasion results in a weighted overlay in which overall risks for each component can be adjusted. The layers included in each model include vegetation, soil, hydrology, disturbance, transportation, and data from the park Exotic Plant Management Teams delineating known invasions. Several layers including connectivity, dispersal, introduction, and spread, are created by the model for inclusion in the weighted outlays. Each layer is integral to the model and the more information in each layer, the more accurate the model will be. Some layers, like areas with increased human traffic or transportation corridors, tend to have more instances of species introduction and are therefore valuable additions to each model (Baker 1984; Dark 2004; and Fei et al. 2009).

Multi-criteria risk assessment models have previously been developed by Michigan Technological University for use by the National Parks of the Great Lakes Network, which includes Pictured Rocks National Lakeshore (Shartell 2007). Spotted 
knapweed (Centaurea maculosa) and garlic mustard (Alliaria petiolata) models previously developed (Shartell 2007) were field tested and adjusted to improve accuracy specifically for Pictured Rocks National Lakeshore. In work reported here, models were compiled and tested for burdock (Arctium minus), bishop's goutweed (Agopodium podagraria), forget-me-not (Myosotis scorpoidies and Myosotis sylvatica), periwinkle (Vinca spp.), red clover (Trifolium pretense), and white and yellow sweet clover (Melilotus spp.) following the same general methodology of the previous models for building risk assessments. The species to be surveyed were selected by the park as the largest threat to natural ecosystems of the park as well as posing the greatest challenge for control efforts (Table 3.1). The final models yielded risk levels for introduction, establishment, and spread of each plant species.

The overall objective of this study was to utilize GIS data to identify areas at high risk for invasion by the eight plants. The specific objectives were to (1) create models in ArcGIS 10 using vegetation, soil, hydrology, soil drainage, transportation, land use, and disturbance feature layers, (2) develop the predictive models and maps for three invasion stages: introduction, establishment, and spread, and (3) test the predictive models for each invasion stage. This project not only provided a basis for monitoring for invasive plants, but also created target areas for management efforts.

\section{Methods}

Field data were collected for the eight invasive plants the park identified as damaging to the park (Table 3.1 and 3.2). Models were then developed for those eight invasive plants. Model development utilized existing data layers as well as field data collected specifically to develop the models and to test their accuracy. Each layer 
included in each stage of invasion was assigned a risk based on the literature review on the life history traits of each species (Table 3.3)

\section{Field Methods}

Field sampling was performed within the boundary and Inland Buffer Zone of Pictured Rocks National Lakeshore. The field data for the models were collected using a random sampling within the park (Figure 3.1). Data were collected for the eight target species (Table 3.4) in July 2008 and July 2009.

For determining the sample size for the random points, Levy and Lemeshow's equation (1999) was used:

$$
\mathrm{n} \geq \frac{\mathrm{z}^{2} \mathrm{~V}_{\mathrm{x}^{2}}}{\mathrm{E}^{2}}
$$

Where $\mathrm{z}=$ the $\mathrm{z}$-value for $\alpha, \mathrm{V}_{\mathrm{x}}=$ the relative variance for the variable $\mathrm{x}$, and $\mathrm{E}=$ the desired error. It was determined that a total of 198 random points would be needed for 95\% confidence interval with 0.1 error. Another 100 points were added to that total based on feedback from Shartell 2007 for development of the models for a total of approximately 300 random points that were visited and measured during the 2008 and 2009 field seasons (104 in 2008 and 202 in 2009) (Figure 3.1).

The random points within the park were generated in ArcGIS and a GPS unit was used to navigate as close to the point as possible. Inaccessible points were reassigned to a new random location within the park. At each point, the exact GPS coordinates were recorded as well as the associated accuracy reading. The locations of the generated random points were later adjusted using the observed coordinates in the field. 
At each random point, a 40 meter by 40 meter plot was established along the cardinal directions. This square was further broken down into sixteen 10m by $10 \mathrm{~m}$ squares. Each of those smaller blocks was assessed for presence and percent cover to the nearest $5 \%$ for the eight invasive plant species. Notes were made on proximity to species of special concern, disturbances, or other populations of invasive plants. These notes are not part of the analysis, but may be useful to the park for later reference.

A total of 114 random points had at least one invasive plant present (Table 3.4, Figures 3.2- 3.6). The 16 values recorded in each 10 by 10 meter subplot were averaged for a single value across the 40 by 40 meter area. This allowed a mean to be assigned to a single pixel in the 40 meter raster output during model analysis instead of creating errors by using each 10 by 10 meter adjacent area.

\section{Model Development}

The risk of invasion for any area varies by invasion stage because each stage depends on different environmental factors. GIS layers the parks had on vegetation, soils, existing invasive plant mapping, or any other pertinent layers were acquired. If a layer did not exist and was considered essential to building the models, a layer was created. For instance, the Miner's Castle area of the park is an area in which invasive plants are most often introduced. A polygon was added to an existing disturbance layer to include that area as an area at high risk for introduction.

The ArcGIS 10 ModelBuilder is an application in ArcGIS used to create, edit, and manage models. The ModelBuilder workspace allows the user to create a model layout by connecting input layers with tools to create outputs that are in turn used as input for the 
next tool (Table 3.11). This process continues until the final output is created from all the components of the model.

Using ModelBuilder, basic invasive plant models were formed using disturbance, soil drainage, vegetation cover, dispersal, connectivity, and presence of already established population (Table 3.5). Previous risk assessment models had included the park boundary as a risk factor; however, that risk factor was removed from these models due to the conclusion that the park boundary was not a factor in the risk of introduction, establishment or spread of any of the invasive plants. Model layouts were documented for future use (Figures 3.15-3.22).

From the basic models, other components could be added to afford more weight to certain risks. For example, a soil drainage component was added to the spread output of spotted knapweed model to reflect that species' propensity to spread in dry areas (USDA 2011). Soil drainage field and vegetation were assigned a risk based on life history attributes for each species (Table 3.6 and 3.7). Risks were then assigned to the layers in each invasion stage (Table 3.8) based on the life history traits of each species. For example, soil drainage in the forget-me-not model was weighted more heavily in the poorly drained soils while sweet clover was assigned a greater risk in areas that are welldrained. Overall risks can be assigned to the different components of the introduction, establishment, and spread raster outputs as long as the percent influence totals $100 \%$ for each phase of invasion. The resolution of the output rasters was set at 40 meters to make analysis precise with the 40 by 40 meter sampling areas. At this point, the models were run to begin the model development. 


\section{Model Analysis}

By assigning values to 40 meter by 40 meter pixels in the raster outputs, the accuracy tests are able to show the accuracy of the model at a pixel level. The random point data was combined with invasions delineated by the park Exotic Plant Management Team. Those two datasets were combined per each plant. The combined dataset was split into $1 / 3$ for model development and the remaining $2 / 3$ of the dataset was used for model testing. The $1 / 3$ of the dataset extracted for development is a reflection of the extra 100 random points added to the field sampling for development.

Using the Spatial Analyst in the ArcMap Toolbox, pixels marked with the presence of the species were extracted from the introduction, establishment, and spread outputs. Those extracted pixels were quantified by the model as having a risk on a scale of 1 to 10. Risk values were extracted using interpolation for each invasion stage for each species. The accuracy of each model was found by dividing the number of pixels extracted in categories 7-10 by the total number of extracted pixels. This process was repeated for all 3 model stages. When the accuracy exceeded or approached the $85 \%$ target, the testing process was repeated using the testing dataset for the final accuracy value. Model stages testing at or above $85 \%$ accuracy were considered to be highly accurate (Shartell 2007; Shartell et al. 2011).

\section{Risk Map Creation}

Risk maps by species were created using the final outputs from the models. The final outputs resulted from determining the most accurate risk values for the weighted overlay and then running the model. The highlighted areas show the areas at greatest risk for invasion in each of the 3 invasion stages. The risk levels 7, 8, 9, and 10 are 
represented by the colors yellow, orange, red, and maroon respectively (Shartell 2007). An overall management risk map was created for each species by combining the raster datasets and re-assigning each pixel with a risk.

Detail maps for introduction, establishment, and spread were compiled (Figures 3.23-3.30). Overall average introduction, establishment, and spread maps were also created for the park to show all ecosystems at risk for invasion by all of the invasive plants (Figures 3.31-3.33). Maximum risk maps for introduction, establishment, and spread were also compiled for all species (Figures 3.34-3.36) These maps were created by combining the raster output from each stage of invasion for each species. For instance, the introduction map is the result of the combination of the model output for the introduction output for the eight invasive species. Another set of maps was created to show the risk of introduction, establishment, and spread of the three species evaluated to be the greatest ecological threat within the park (Figures 3.37-3.39). The raster outputs for spotted knapweed, garlic mustard, and sweet clover were combined to show the areas at highest risk of invasion by those three species. This illustrates how the model outputs can be adapted to serve different land management goals.

\section{Results}

The accuracies of each invasion stage for each species when the model was first run with the numbers hypothesized from the literature review ranged from $0 \%$ to $100 \%$ (Table 3.9). While the risks assigned to the individual layers remained the same due to the literature review, the risks for the weighted overlay were adjusted to give different components a different weight. This step changed the original accuracy percentages and ultimately yielded the development testing accuracies. 
An accuracy of 85\% was considered an acceptable level of accuracy, as higher accuracies may identify too much of the park as high risk. The periwinkle model tested at very low accuracies; however, that is probably due to the very small number of pixels in the development dataset (Table 3.10). However, the distribution of periwinkle was predicted at 100\% accuracy using the testing dataset. Species testing at high accuracies in model development include burdock, bishop's goutweed, and red clover. Forget-menot, spotted knapweed, and sweet clover tested below 85\% accuracy for one or more stages of invasion.

A few species fell below the $85 \%$ accuracy threshold during the final test, including burdock, forget-me-not, and spotted knapweed. Forget-me-not and spotted knapweed tested below $85 \%$ for only the introduction stage. Burdock tested below $80 \%$ for all stages despite development accuracies testing above 85\%. Bishop's goutweed, garlic mustard, periwinkle, red clover, and sweet clover tested at or above $85 \%$ for all stages of invasion.

Maps that combined the highest risks of introduction, establishment, and spread were determined to be the most useful to field personnel. Burdock tested at the lowest accuracy at approximately 70\% in its management map (Figure 3.7). Bishop's goutweed showed a management accuracy of 98\% (Figure 3.8) and forget-me-not tested at an accuracy of $89 \%$ (Figure 3.9), while garlic mustard and periwinkle both tested at 100\% accuracy (Figures 3.10 and 3.11). Red clover showed a high accuracy of 96\% (Figure 3.12) and spotted knapweed tested at 88\% accuracy (Figure 3.13).

\section{Discussion}

Burdock is a thistle that can be introduced to areas by dispersal of its seeds encased by burrs (United States Department of Agriculture 2011). It is drought resistant 
and can therefore out-compete other native species in dry environments (Haragan 1991; Stubbendieck et al. 1994). The maps for burdock found that roadsides are at highest risk for introduction and moist forested environments are most at risk for establishment and spread. This species had the lowest accuracy levels during testing, perhaps due to the literature review indicating this species could be found in a wide assortment of habitats.

Bishop's goutweed is an aggressive invader that greatly reduces species diversity (United States Department of Agriculture 2011). It is shade tolerant and will spread into the understory of any forest (Gleason and Cronquist 1991). Much of the park is highlighted in the output due to the high risk of all three stages of invasion in all forested ecosystems of the park. Each stage of this model tested above 96\%, indicating a very high level of accuracy in predicting which areas of the park might be invaded by bishop's goutweed. This could also indicate that the literature review showed very precise habitat requirements.

Forget-me-not is a garden escapee in the park and is most often found in moist environments, including wet ditches (United States Department of Agriculture 2011). It can displace native understory species in wet woodlands (Hoffman and Kearns 1997; Sanders 2003). The output maps for this species show that transportation corridors and streams are most at risk for introduction. Areas most at risk for establishment and spread are wet areas including streambeds, wetlands, and wet woodlands, which reflects the literature review. The stages of invasion tested above $83 \%$ accuracy, which although falling slightly below the target, is still fairly accurate.

Garlic mustard is an aggressive invader in hardwood forests (United States Department of Agriculture 2011). This species can create monocultures in shaded hardwood understories (Cavers et al. 1979; Anderson et al. 1996), so the presence of this 
species could be detrimental to the species diversity of the park. Not much of the park showed a high risk of introduction or spread of garlic mustard, although much of the park is at risk for establishment. This coincides with the results of an Upper Peninsula garlic mustard model (Shartell et al. 2011). Each stage of the model tested at 100\% for the data provided by the park. With 90 pixels in the testing dataset, this is a fairly accurate model that indicates that the areas most at risk are hardwood forests. This model will be particularly useful for monitoring the park.

Periwinkle is another escapee from old homesteads in the park and can crowd out native vegetation (Muenscher 1955; McClintock 1985). This species invades almost any habitat, but is often found along streams and rivers (Glikey 1957; Miller 2003). Fragments of vegetation can be carried downstream, where they can root and begin invading (Munz and Keck 1973; Swearingen et al. 2002). The output of this model reflects the life history traits stated in the literature, highlighting wet areas at highest risk. Each stage of this model tested at 100\% accuracy, although this may have more to do with the low number of pixels available for testing than the model truly being that accurate.

Red clover is an invader of fields, roadsides, and waste areas (Duke 1981; Taylor and Smith 1981). It is a nitrogen-fixer and can therefore alter the nutrient content of the environment it invades (United States Department of Agriculture 2011). The model output reflects the habitat preference of this species. Dry, open areas are identified by the model as being most at risk for establishment. The 95\% and greater accuracies for each stage of this model indicate an accurate predictive tool for this species, and indicates the plants are found in habitats the literature review indicated. 
Spotted knapweed is an invader of open areas (Jacobs and Sheley 1998). It releases allelopathic chemicals into the soil to reduce competition with other species; therefore, it can indirectly affect the species diversity of a plant community (Sheley et al. 1998; Story 2002; United States Department of Agriculture 2011). The spotted knapweed model introduction output tested at $80.7 \%$, which may be slightly lower than the target because many of the small roads in the interior of the park are unmapped. Many spotted knapweed populations were found in the random points along old logging roads, so the missing data may be affecting the introduction stage of this model. The establishment and spread phases tested above $96 \%$, which is satisfactory. The model reflects the literature review and tests accurately when tested with field data.

Sweet clover is an invader of open, dry areas throughout North America (Haragan 1991; United States Department of Agriculture 2011). This species also fixes nitrogen, which can alter the plant communities in which it is introduced (Southern Weed Science Society 1998). The species grows quickly and overtops native species, which can ultimately decrease species diversity (Stubbendieck et al. 1994; Whitson et al. 1996). Each stage of the model tested between $80 \%$ and $90 \%$, indicating an adequate level of accuracy. The model output shows most of the park at a low to moderate risk of introduction, which means this model needs more field data with which its accuracy can be honed. Otherwise, the model identifies areas that the literature indicates should be at risk of invasion.

If the models test too high in accuracy, it is possible the entire park would be seen as high risk, which would defeat the purpose of the models. Low accuracies could cause the models to not identify areas most at risk. Adjusting the risks assigned to each layer or each component of the weighted output is the solution to either of these problems. The 
models will continue to get more accurate as more information is added to the models. The risks could be infinitely adjusted and this is the stage of the modeling process that takes the longest amount of time.

The average risk assessment maps for each species created from the model output (Figure 3.7-3.13) seem to be a generally good representation of each species. Using one map, the park can identify areas at risk for any stage of invasion for each species. Due to the averaging process, however, fewer areas will be identified as high risk, so these maps could be less useful than the 3-stage output maps.

The output maps showing the average risk of each stage of invasion do not have as much area highlighted as expected (Figures 3.31-3.33). The risk values generally averaged each other out so only sparse areas were calculated to be at risk. When the maximum risk maps were compiled, most of the park was highlighted as being moderate to high risk, which could be useful in identifying areas at the very highest risk of invasion (Figure 3.34-3.36). The output maps targeted at 3 invasive species (Figures 3.37-3.39) is an example of how the models can be adjusted to target the most ecologically damaging plants and yield an output useful for the field.

A possible source of error noted during model development is that many of the small roads throughout the park are not mapped. The old logging roads, 2-tracks, and skid trails could be a major vector for introduction and including that GIS data in the models could significantly improve model accuracy. The park may also want to delineate trailheads and include them as disturbed area or well-traveled areas as a source of introduction. 
The final accuracies of the models were generally acceptable, which indicates that the models are good tools for ecological risk assessment. Taking into account the different environmental requirements of each species is one strength of the models (Radosevich 2007). The combinability of each invasion stage is another strength of the models because land managers can combine the outputs in many ways to make them useful to a range of management goals. For Pictured Rocks National Lakeshore, these models are a much-needed solution to resource shortages.

Risk models are not the ultimate management tool; however, they can be useful to land managers who need more direction in their control and monitoring efforts. They are not the only tools needed to make management decisions, but can make management decisions easier and more focused.

\section{Continuing Research}

Using the cumulative resources of the National Park Service, such as the extensive vegetation inventories and continued mapping, the models can be built and refined using the best data available. From here, we are optimistic that more public land managers will observe the usefulness of multi-criteria risk assessment models and begin to use and rely upon similar technologies on their lands.

\section{Acknowledgements}

Michael D. Hyslop of Michigan Technological University provided invaluable guidance and input throughout this project. Joseph Latsch and Andrew Hallfrisch provided help with field work and data entry. Lindsey M. Shartell provided help with the testing process. 


\section{Literature Cited}

Baker, H.G. 1984. Patterns of plant invasion in North America. Pp. 44-57 in Mooney, H.A. and J. A. Drake, eds. Ecology of biological invasions in North America and Hawaii. New York: Springer-Verlag.

Booth, M.S., M.M. Caldwell, and J.M. Stark. 2003. Overlapping resource us in three Great Basin species: implications for community invasibility and vegetation dynamics. Journal of Ecology 91: 36-48.

Byers, J., S. Reichard, J.M. Randall, I.M. Parker, C.S. Smith, W.M. Lonsdale, I.A.E. Atkinson, M. Williamson, E. Choresky, and D. Hayes. 2002. Directing research to reduce the impacts of nonindigenous species. Conservation Biology 6:630-640.

Ciesla, W.M. 2000. Remote sensing in forest health protection. USDA Forest Service, Forest Health Technology Enterprise Team, Fort Collins, CO.

Cizek, O., A. Bakesova, T. Kuras, J. Benes, M. Konvicka. 2004. Vacant niche in alpine habitat: the case of an introduced population of the butterfly Erebia epiphron in the Krkonose mountains. Acta Oecologica 24:1.

Colautti, R.I., and H.J. MacIsaac. 2004. A neutral terminology to define invasive species. Diversity and Distributions 10:135-141.

Cousens, R., and M. Mortimer. 1995. Dynamics of weed populations. Cambridge University Press, Cambridge. 332 p.

Daehler, C. 1998. The taxonomic distribution of invasive angiosperm plants: ecological insights and comparison to agricultural weeds. Biological Conservation 84:167180.

Dark, S.J. 2004. The biogeography of invasive alien plants in California: an application of GIS and spatial regression analysis. Diversity Distribution 10: 1-9.

Davis, M.A., J.P. Grime, K. Thompson. 2000. Fluctuating resources in plant communities: a general theory of invasibility. Journal of Ecology 88: 528-534.

Fei, S., N. Kong, J. Stringer, D. Bowker. 2009. Invasion pattern of exotic plants in forest ecosystems. Pp. 59-70 in R.K. Kohli, S. Jose, H.P. Singh, D.R. Batish, eds. Invasive Plants and Forest Ecosystems. Boca Raton, Florida: CRC Press.

Goodwin, B.J., A.J. McAllister, and L. Fahrig. 1999. Predicting invasiveness of plant species based on biological information. Conservation Biology 13: 422-426.

Groves, R.H. 1999. Sleeper weeds. Pp. 632-636 in A.C. Bishop, M. Boersma, and C.D. Barnes, eds. Weed Management into the $21^{\text {st }}$ Century: do we know where we are going? Proceedings of the $12^{\text {th }}$ Australian Weeds Conference. Tasmainian Weeds Society, Hobart.

Groves, R.H. 2006. Are some weeds sleeping? Some concepts and reasons. Euphutica 148:111-120. 
Holcombe, T., and T.J. Stohlgren. 2009. Detection and early warning of invasive species. Pp. 36-46 in M.N. Clout and P.A. Williams, eds. Invasive Species Management. Oxford: Oxford University Press.

Jager, H.I. and W.S. Overton. 1993. Explanatory models for ecological response surfaces. Environmental Monitoring with GIS. New York: Oxford University Press.

Kolar, C.S. and D.M. Lodge. 2001. Progress in invasion biology: predicting invaders. Trends in Ecology and Evolution 16:199-204.

Lavergne, S., and J. Molofsky. 2004. Reed canary grass (Phalaris arundinacea) as a biological model in the study of plant invasions. Critical Reviews in Plant Sciences 23(5):415-429.

Levy, P.S. and S. Lemeshow. 1999. Sampling of Populations. New York, New York: John Wiley \& Sons.

Lockwood, J.L., D. Simberloff, M.L. McKinney and B. Von Holle. 2001. How many, and which, plants invade natural areas? Biological Invasions 3: 1-8.

Mack, R.N. 1996. Predicting the identity and fate of plant invaders: emergent and emerging approaches. Biological Conservation 78:107-121.

McRoberts, R.E., R.J. Barbour, K.M. Gebert, G.C. Liknes, M.D. Nelson, D.M. Meneguzzo, S.L. Odell, S.C. Yaddof, S.M. Stein, H.T. Mowrer, K.L. Gerlitz, and W.M. Gerlitz. 2006. Using basic Geographic Information Systems functionality to support sustainable forest management decision making and post-decision assessments. Journal of Sustainable Forestry 23(3).

Monaco T., S. Weller,F. Ashton. 2002. Weed Science: Principles and Practices. New York, New York: John Wiley \& Sons, Inc. 671p.

Mooney, H. and R. Hobbs. 200o. Invasive Species in a Changing World. Washington, D.C.: Island Press.

Myers, J.H. and D.R. Bazely. 2003. Ecology and Control of Introduced Plants. Cambridge, UK: Cambridge University Press.

National Park Service. 2010. NPS Overview. Pamphlet.

National Park Service. 2011a. U.S. National Park Service. www.nps.gov. Accessed: April 2011.

National Park Service. 2011b. Pictured Rocks National Lakeshore. www.nps.gov/piro. Accessed March 2011.

National Research Council. 2002. Predicting invasions of nonindigenous plants and plant pests. Washington, D.C.: National Academy Press.

Pimentel, D., L. Lach, R. Zuniga, and D. Morrison. 1999. Environmental and economic costs associated with non-indigenous species in the United States. Bioscience 50:53-65. 
Pyšek, P., K. Prach, and P. Smilauer. 1995. Relating invasions success to plant traits. An analysis of the Czech alien flora. Pp. 39-6o in P. Pysek, K. Prach, M. Rejmanek, and M. Wade, eds. Plant Invasions: General Aspects and Special Problems, Academic Press Publishing, Amsterdam. Pp. 39-60.

Pyšek, P., D.M. Richardson, and M. Williamson. 2004. Predicting and explaining plant invasions through analysis of source area floras: some critical considerations. Diversity and Distributions 10:179-187.

Radosevich, S.R., J.S. Holt, C.M. Ghersa. 2007. Ecology of Weeds and Invasive Plants. Hoboken, New Jersey: John Wiley \& Sons, Inc. 454p.

Rejmánek, M. 2000. Invasive plants: Approaches and predictions. Australian Ecology 25:497-506.

Reichard, S.E., and C.W. Hamilton. 1997. Prevention of invasive plant introductions on national and local levels. Pp. 215-240 in J.O. Luken and J.W. Thieret, eds. Assessment and Management of Plant Invasions. Springer, New York.

Reynolds, K.M. 1999. EMDS Users Guide (version 2.0): Knowledge-based decision support for ecological assessment. General Technology Report PNW-GTR-470. Portland, OR: USDA Forest Service, Pacific Northwest Station. 63 p.

Shartell, L.M. 2007. Risk assessment for invasive exotic plants using predictive modeling. M.S. Thesis. Houghton, Michigan: Michigan Technological University.

Shartell, L.M., L.M. Nagel, A.J. Storer. 2011. Multi-criteria risk model for garlic mustard (Alliaria petiolata) in Michigan's Upper Peninsula. American Midland Naturalist 165:116-127.

Stohlgren, T.J., and C.S. Jarnevich. 2009. Risk Assessment of invasive species. Pp. 19-35 in M.N. Clout and P.A. Williams, eds. Invasive Species Management. Oxford University Press, Oxford.

Stohlgren, T.J. and J.L. Schnase. 2006. Risk analysis for biological hazards: what we need to know about invasive species. Risk Analysis 23: 163-173.

Theoharides, K.A. and J.S. Dukes. 2007. Plant invasion across space and time: factors affecting nonindigenous species success during four stages of invasion. New Phytologist 176:256-273.

Underwood, E.C., R. Klinger, and P.E. Moore. 2004. Predicting patterns of non-native plant invasions in Yosemite National Park, California, USA. Diver Distribution 10:447-459.

United States Department of Agriculture. 2011. The PLANTS Database. National Plant Data Center, Baton Rouge, LA, USA. http://plants.usda.gov. Accessed: March 19, 2011.

Vasquez, E.A., J.J. James, T.A. Monaco, D.C. Cummings. 2010. Invasive plants on rangelands: a global threat. Rangelands 32(1):3-5. 


\section{References For Species}

\section{Bishop's goutweed references:}

Bailey, W.W. 1987. Journal of the Torrey Botanical Society 3: 176.

Borg-Karlson, A. K., I. Valternova, and L. A. Nilsson. 1994. Volatile compounds of flowers of six species in the family Apiaceae: bouquets for different pollinators? Phytochemistry 35: 111-118.

Dlussky, G. M. 1998. Mechanisms of competition for pollinators in Anthriscus sylvestris Hoffm. and Aegopodium podagraria L. (Apiaceae). Zhurnal Obshchei Biologii 59: 24-44. Everett, T. H. 1981.

The New York Botanical Garden illustrated encyclopedia of horticulture. Vol. 1. A-Be. New York: Garland Publishing Inc.

Gatsuk, L. E., O. V. Smirnova, L. I. Vorontzova, L. B. Zaugolnova, and L. A. Zhukova. 1980. Age states of plants of various growth forms: a review. Journal of Ecology 68: 675-696.

Gleason, H. A., and A. Cronquist. 1991. Manual of vascular plants of northeastern United States and adjacent Canada, 2nd ed. New York Botanical Garden, New York.

Grime, J. P., J. G. Hodges, and R. Hunt. 1988. Comparative plant ecology. Unwin Hyman, London.

Small, E. 1973. Photosynthetic ecology of normal and variegated Aegopodium podagraria. Canadian Journal of Botany 51: 1589-1592.

Swearingen, J. 2004. WeedUS: Database of Invasive Plants Affecting Natural Areas in the U.S. http://www.nps.gov/plants/alien. Accessed: March 2011.

Tutin, T. G., V. H. Heywood, N. A. Burges, D. M. Moore, D. H. Valentine, S. M. Walker, and D. A. Webb, eds. 1968. Flora Europaea, Vol. 2. Cambridge University Press, Cambridge.

\section{Burdock references:}

Haragan, P.D. 1991. Weeds of Kentucky and adjacent states: a field guide. Lexington, Kentucky: University Press of Kentucky.

Hoffman, R. and K. Kearns, eds. 1997. Wisconsin manual of control recommendations for ecologically invasive plants. Wisconsin Dept. Natural Resources. Madison, Wisconsin.

Stubbendieck, J., G.Y. Friisoe, \& M.R. Bolick. 1994. Weeds of Nebraska and the Great Plains. Nebraska Department of Agriculture, Bureau of Plant Industry. Lincoln, Nebraska.

Southern Weed Science Society. 1998. Weeds of the United States and Canada. CDROM. Southern Weed Science Society. Champaign, Illinois.

United States Forest Service. 2005. Common burdock. Forest Health Staff, Newtown Square, PA.

Uva, R.H., J.C. Neal, \& J.M. DiTomaso. 1997. Weeds of the Northeast. Ithaca, New York: Cornell University Press.

Whitson, T.D., eds. 1996. Weeds of the West. Laramie, Wyoming: University of Wyoming. $628 \mathrm{p}$.

\section{Forget-me-not references:}

Hoffman, R. and K. Kearns, eds. 1997. Wisconsin manual of control recommendations for ecologically invasive plants. Wisconsin Dept. Natural Resources. Madison, Wisconsin.

Sanders, Jack. 2003. The Secrets of Wildflowers: A Delightful Feast of Little-Known 
Facts, Folklore, and History. Globe Pequot.

Garlic mustard references:

Anderson, R. C., S. S. Dhillion, and T. M. Kelley. 1996. Aspects of the ecology of an invasive plant, garlic mustard (Alliaria petiolata), in central Illinois. Restoration Ecology 4:181-191.

Baskin, J. M. and C. C. Baskin. 1992. Seed germination biology of the weedy biennial Alliaria petiolata. Natural Areas Journal 12:191-197.

Cavers, P. B., M. I. Heagy, and R. F. Kokron. 1979. The biology of Canadian weeds. Canadian Journal of Plant Science 59:217-229.

Nuzzo, V.A. 1999. Invasion pattern of the herb garlic mustard (Alliaria petiolata) in high quality forests. Biological Invasions 1:169-179.

Welk, E., K. Schubert, and M. H. Hoffmann. 2002. Present and potential distribution of invasive garlic mustard (Alliaria petiolata) in North America. Divers Distribution 8:219-233.

\section{Periwinkle references:}

Gilkey, H. 1957. Weeds of the Pacific Northwest. Oregon State College, OR.

Lawrence, G. 1959. Vinca and CATHARANTHUS. Baileya 7:113.

McClintock, E. 1985. Escaped exotic weeds in California. Fremontia 12:3 6.

Miller, James H. 2003. Nonnative invasive plants of southern forests: a field guide for identification and control. Gen. Tech. Rep. SRS-62. Asheville, NC: U.S. Department of Agriculture, Forest Service, Southern Research Station. 93 p.

Muenscher, W. 1955. Weeds. 2nd ed. MacMillan, NY.

Munz, P.A. and D.D. Keck. 1973. A California flora and supplement. Berkeley, California: University of California Press.

Swearingen, J., K. Reshetiloff, B. Slattery, and S. Zwicker. 2002. Plant Invaders of Mid-Atlantic Natural Areas. National Park Service and U.S. Fish \& Wildlife Service, $82 \mathrm{p}$.

\section{Red clover references:}

Duke, J.A. 1981. Handbook of legumes of world economic importance. New York: Plenum Press.

Duke, J.A. 1984. Borderline herbs. Boca Raton, FL: CRC Press.

Taylor, N.L. and Smith, R.R. 1981. Red clover Trifolium pratense. Pp. 11-21 in McClure, T.A. and E.S. Lipinsky eds. Handbook of biosolar resources, Vol. II. Resource materials. Boca Raton, FL: CRC Press, Inc.

\section{Spotted knapweed references:}

Jacobs, J. S. and R. L. Sheley. 1998. Observation: life history of spotted knapweed. J Range Manage 51:665-673.

Sheley, R. L., J. S. Jacobs, and M. F. Carpinelli. 1998. Distribution, biology, and management of diffuse knapweed (Centaurea diffusa) and spotted knapweed (Centaurea maculosa). Weed Technology 12:353-362.

Story, J. 2002. Spotted Knapweed. Pp. 149-157 in Driesche, R. V., B. Blossey, M. Hoddle, S. Lyon, and R. Reardon, eds. Biological Control of Invasive Plants in the Eastern United States. U. S. Department of Agriculture, Forest Service.

Voss, E. G. 1985. Michigan Flora. Part II Dicots. Cranbrook Institute of Science and University of Michigan Herbarium.

Watson, A. K. and A. J. Renney. 1974. The biology of Canadian weeds 6. Centaurea diffusa and C. maculosa. Canadian Journal of Plant Science 54:687-701.

Sweet clover references: 
Haragan, P.D. 1991. Weeds of Kentucky and adjacent states: a field guide. The University Press of Kentucky. Lexington, Kentucky.

Hoffman, R. \& K. Kearns, eds. 1997. Wisconsin manual of control recommendations for ecologically invasive plants. Wisconsin Dept. Natural Resources. Madison, Wisconsin.

Southern Weed Science Society. 1998. Weeds of the United States and Canada. CDROM. Southern Weed Science Society. Champaign, Illinois.

Stubbendieck, J., G.Y. Friisoe, \& M.R. Bolick. 1994. Weeds of Nebraska and the Great Plains. Nebraska Department of Agriculture, Bureau of Plant Industry. Lincoln, Nebraska.

Whitson, T.D., ed. 1996. Weeds of the West. Western Society of Weed Science in cooperation with Cooperative Extension Services, University of Wyoming. Laramie, Wyoming. 
Table 3.1. Plant species for which multi-criteria risk models were developed for Pictured Rocks National Lakeshore, Alger County, Michigan. The codes for each of the eight plant species are also included.

\begin{tabular}{lll}
\hline Code & Common Name & Species Name \\
\hline BD & Burdock & Arctium minus \\
BW & Bishop's Goutweed & Aegopodium podgraria \\
FM & Forget-me-not & Myosotis spp. \\
GM & Garlic Mustard & Alliaria petiolata \\
PW & Periwinkle & Vinca spp. \\
RC & Red Clover & Trifolium pratense \\
SK & Spotted Knapweed & Centaurea maculosa \\
WC & Sweet clover & Melilotus spp. \\
\hline
\end{tabular}


Table 3.2. Ecological impacts of each invasive plant for which a model was produced. Highlighted species were the three species selected as having the potential to do the most ecological damage within the park based on life history traits and the potential habitats within Pictured Rocks National Lakeshore.

\begin{tabular}{|c|c|}
\hline Invasive Plant & Ecological Implications \\
\hline Burdock & $\begin{array}{l}\text { Invader of pastures, hay fields, and prairies. Secondary host for } \\
\text { pathogens that affect economically important plants. (Haragan } \\
\text { 1991) }\end{array}$ \\
\hline Bishop's goutweed & $\begin{array}{l}\text { Aggressive. Greatly reduces species diversity. Highly shade } \\
\text { tolerant and capable of invading closed-canopy forests. } \\
\text { Vegetative reproduction. (Bailey 1981; Gatsuk et al. 1990) }\end{array}$ \\
\hline Forget-me-not & $\begin{array}{l}\text { Competes with native wet vegetation, creates thick patches. } \\
\text { (Hoffman and Kearns 1997; Sanders 2003) }\end{array}$ \\
\hline Garlic mustard & $\begin{array}{l}\text { Aggressive. Allelopathic. Outcompetes native vegetation for } \\
\text { resources and creates monoculture. Deprives wildlife species of } \\
\text { early plants as a food source. (Voss 1985; Welk et al. 2002) }\end{array}$ \\
\hline Periwinkle & $\begin{array}{l}\text { Aggressive. Outcompetes native ground cover by dominating } \\
\text { substrate, water, and nutrients. (Swearingen et al. 2002) }\end{array}$ \\
\hline Red Clover & $\begin{array}{l}\text { Impacts community composition. Spreads by prolific seed } \\
\text { production preferable to wildlife. (Duke 1981; USDA 1983) }\end{array}$ \\
\hline Spotted Knapweed & $\begin{array}{l}\text { Allelopathic. Displaces native vegetation and reduces forage } \\
\text { potential for wildlife and livestock. Will spread into rare dune } \\
\text { ecosystems. (Voss 1985; Sheley et al. 1998) }\end{array}$ \\
\hline Sweet clover & $\begin{array}{l}\text { Shades out native plants in grasslands. Contains coumarin } \\
\text { which is toxic to animals. (Whitson et al. 1996) }\end{array}$ \\
\hline
\end{tabular}

Note: None of these plants are considered noxious in the state of Michigan, nor are they on the Federal Noxious Weed List. 


\begin{tabular}{|c|c|c|c|c|c|c|c|c|}
\hline & 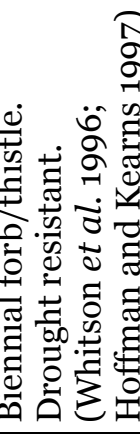 & 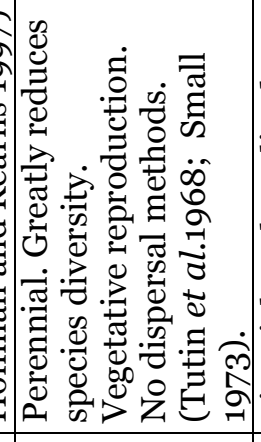 & 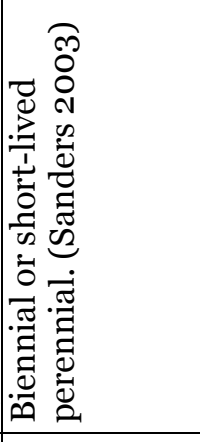 & 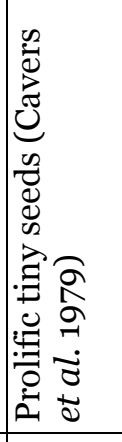 & 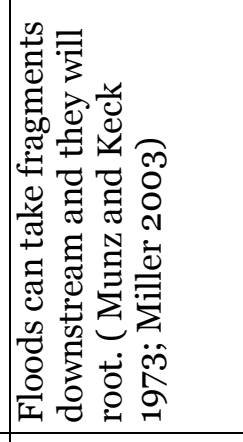 & 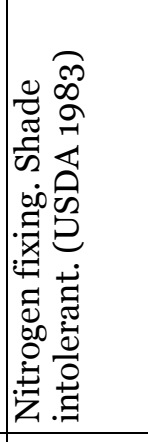 & 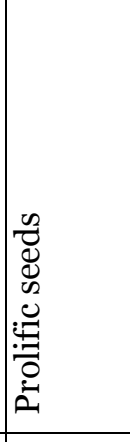 & 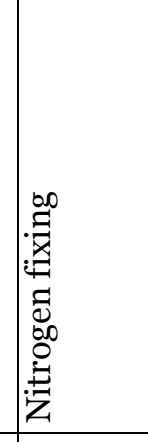 \\
\hline & 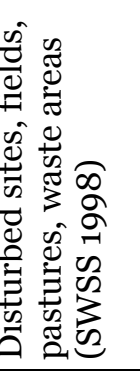 & 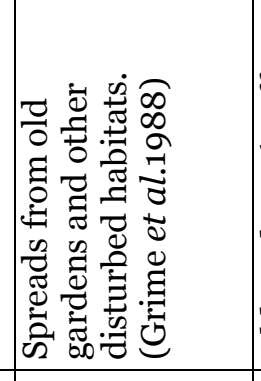 & 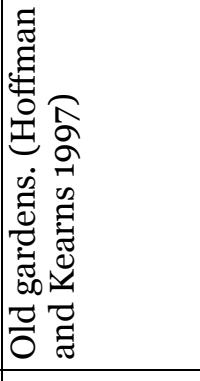 & 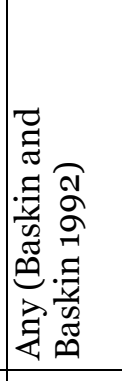 & 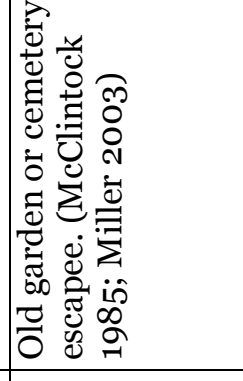 & 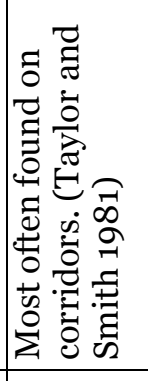 & 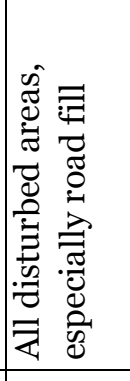 & 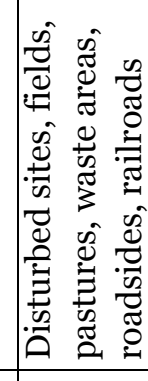 \\
\hline & 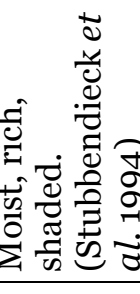 & 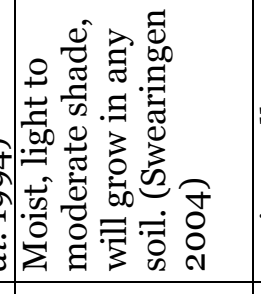 & 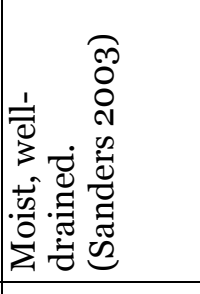 & 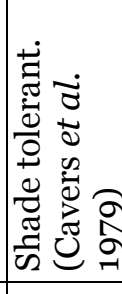 & 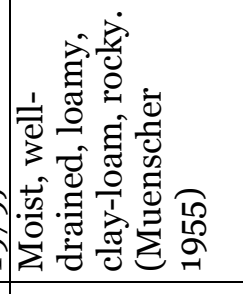 & 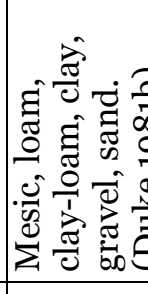 & 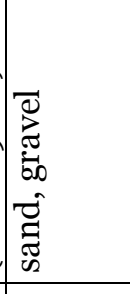 & 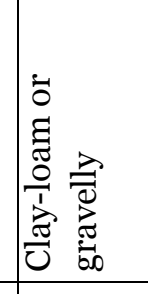 \\
\hline 它 & 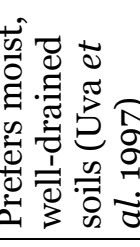 & 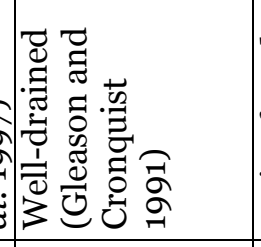 & 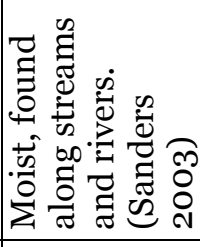 & 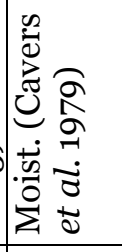 & 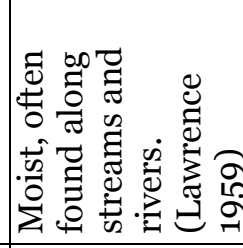 & 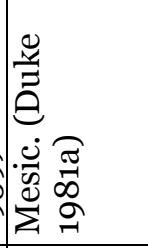 & $\vec{\Delta}$ & 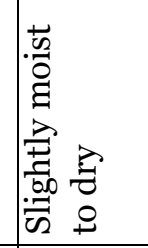 \\
\hline & 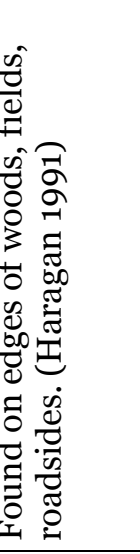 & 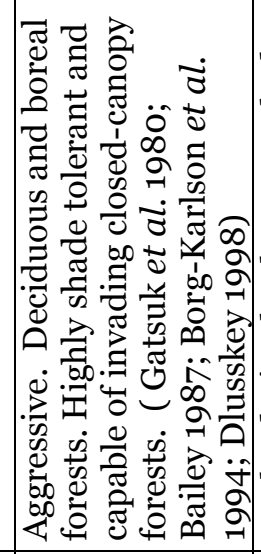 & 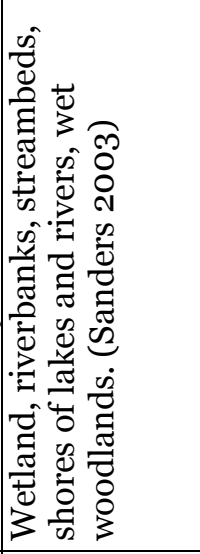 & 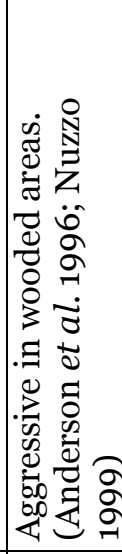 & 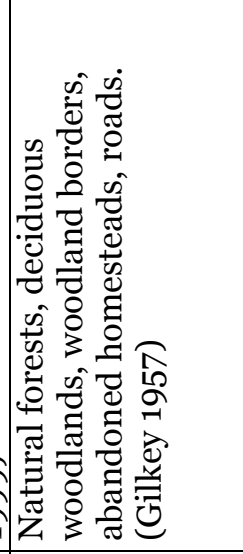 & 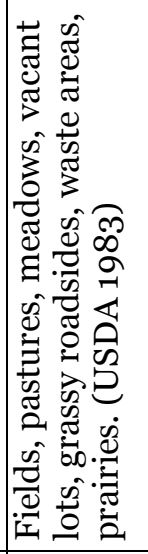 & 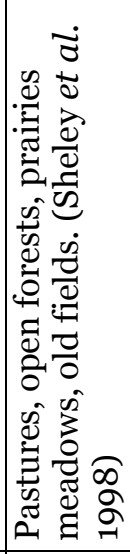 & 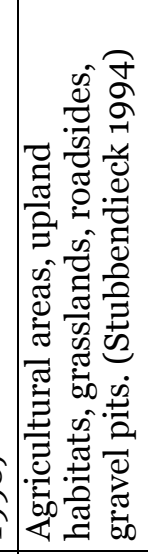 \\
\hline 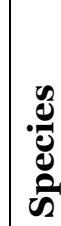 & 胥 & 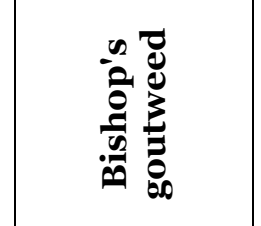 & 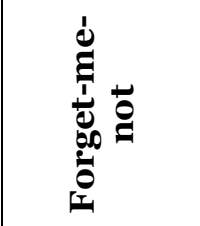 & 施 & 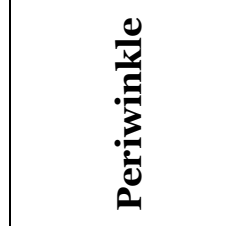 & 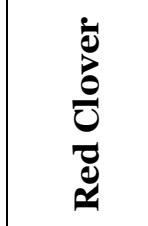 & 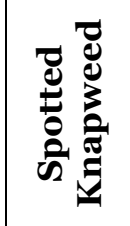 & 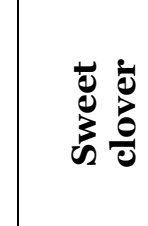 \\
\hline
\end{tabular}


Table 3.4. The number and percentage of random points sampled in Pictured Rocks National Lakeshore, Alger County, Michigan in $2008(n=104)$ and $2009(n=202)$ in which each species occurred.

\begin{tabular}{lccc}
\hline Species & Presence & Percentage & SE \\
\hline Burdock & 38 & 12.46 & 1.89 \\
Bishop's Goutweed & 9 & 2.95 & 0.97 \\
Forget-me-not & 39 & 12.79 & 1.91 \\
Garlic Mustard & 0 & 0.00 & $\mathrm{n} / \mathrm{a}$ \\
Periwinkle & 1 & 0.33 & 0.33 \\
Red Clover & 29 & 9.51 & 1.68 \\
Spotted Knapweed & 36 & 11.80 & 1.85 \\
Sweetclover & 9 & 2.95 & 0.97 \\
\hline
\end{tabular}




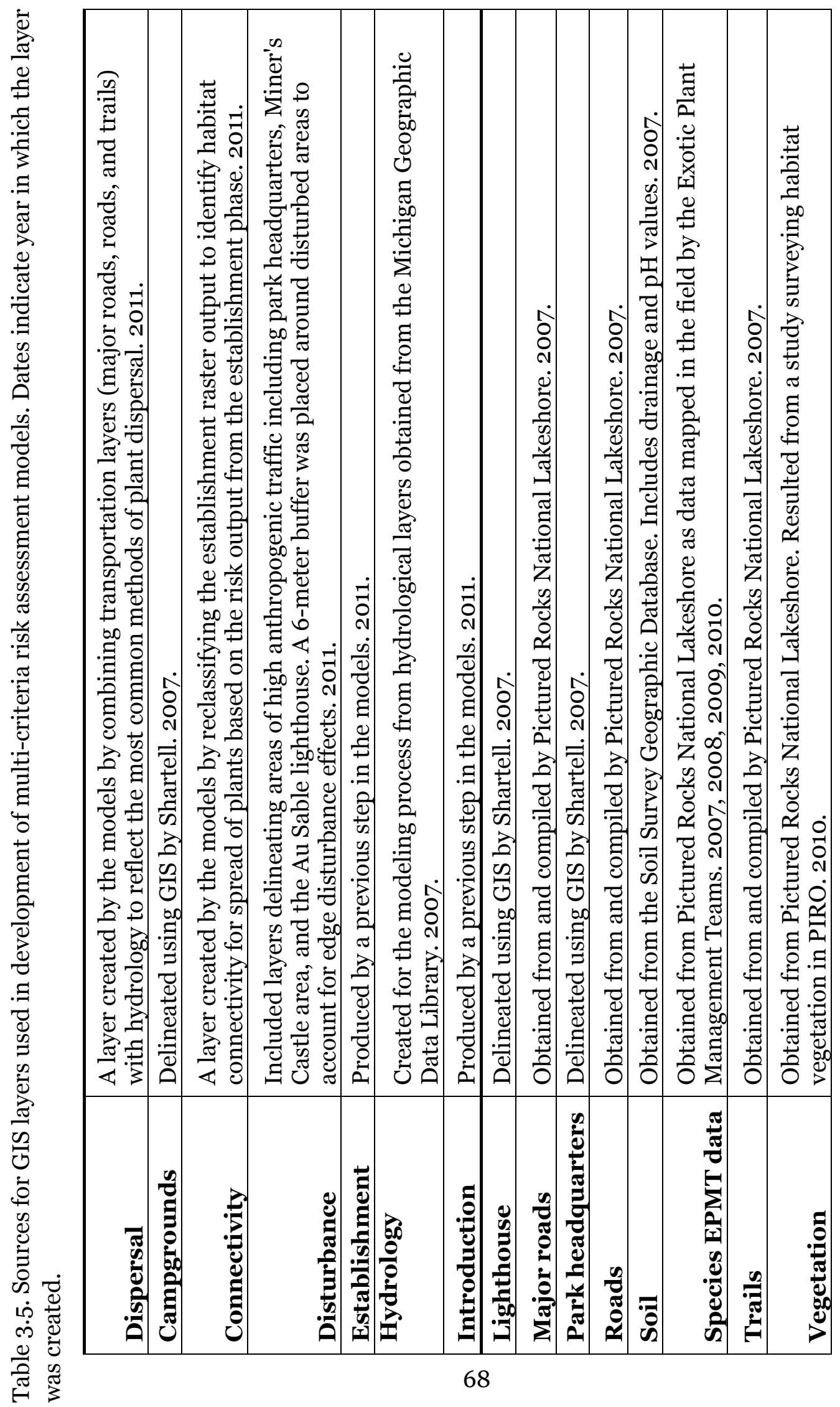


Table 3.6. Risk values entered into each model for soil drainage categories per each species for models developed for Pictured Rocks National Lakeshore, Alger County, Michigan. Values were determined based on life history traits determined by the literature review. BD is burdock, BW is bishop's goutweed, FM is forget-me-not, GM is garlic mustard, $\mathrm{PW}$ is periwinkle, $\mathrm{RC}$ is red clover, $\mathrm{SK}$ is spotted knapweed, and WC is sweet clover.

\begin{tabular}{lcccccccc}
\hline Soil Drainage & BD & BW & FM & GM & PW & RC & SK & WC \\
\hline Excessively Drained & 2 & 4 & 4 & 6 & 2 & 8 & 10 & 10 \\
Somewhat Excessively Drained & 4 & 8 & 4 & 8 & 4 & 8 & 10 & 10 \\
Well Drained & 10 & 10 & 10 & 10 & 6 & 8 & 10 & 10 \\
Moderately Well Drained & 8 & 8 & 10 & 10 & 8 & 10 & 8 & 8 \\
Somewhat Poorly Drained & 4 & 6 & 8 & 2 & 10 & 10 & 6 & 6 \\
Poorly Drained & 2 & 4 & 6 & 2 & 10 & 8 & 4 & 4 \\
Very Poorly Drained & 2 & 4 & 6 & 2 & 6 & 8 & 2 & 2 \\
Water & $\mathrm{O}$ & $\mathrm{O}$ & $\mathrm{O}$ & $\mathrm{O}$ & $\mathrm{O}$ & $\mathrm{O}$ & $\mathrm{O}$ & $\mathrm{O}$ \\
No Data & $\mathrm{O}$ & $\mathrm{O}$ & $\mathrm{O}$ & $\mathrm{O}$ & $\mathrm{O}$ & $\mathrm{O}$ & $\mathrm{O}$ & $\mathrm{O}$ \\
\hline
\end{tabular}


Table 3.7. Risk values entered into each model for vegetation categories per each species for models developed for Pictured Rocks National Lakeshore, Alger County, Michigan. Values were assigned based on life history traits determined by the literature review. BD is burdock, BW is bishop's goutweed, FM is forget-me-not, GM is garlic mustard, PW is periwinkle, RC is red clover, SK is spotted knapweed, and WC is sweet clover.

\begin{tabular}{lcccccccc}
\hline Vegetation & BD & BW & FM & GM & PW & RC & SK & WC \\
\hline Steep sand bluff & 4 & 4 & 4 & 2 & 4 & 4 & 8 & 4 \\
Northern Hardwoods & 10 & 10 & 9 & 10 & 8 & 5 & 6 & 5 \\
Beach Strand & 3 & 3 & 3 & 3 & 3 & 5 & 8 & 3 \\
Cleared Area & 10 & 10 & 10 & 10 & 10 & 10 & 10 & 10 \\
Red \& White Pine & 5 & 4 & 4 & 1 & 4 & 4 & 6 & 4 \\
Dunes plant communities & 3 & 3 & 3 & 3 & 1 & 8 & 10 & 3 \\
Wetland shrub & 3 & 3 & 10 & 3 & 10 & 2 & 8 & 2 \\
White Cedar & 3 & 3 & 5 & 1 & 5 & 3 & 6 & 3 \\
Jack Pine & 3 & 3 & 5 & 1 & 5 & 3 & 6 & 3 \\
White Birch & 7 & 6 & 8 & 7 & 5 & 5 & 6 & 4 \\
Undefined & 2 & 2 & 2 & 2 & 2 & 2 & 2 & 2 \\
Cedar & 3 & 3 & 5 & 7 & 5 & 3 & 6 & 3 \\
Wetland shrub - bog & 3 & 3 & 10 & 3 & 10 & 2 & 4 & 2 \\
Water & 1 & 1 & 1 & 1 & 1 & 1 & 1 & 1 \\
Red Pine & 5 & 4 & 4 & 1 & 4 & 4 & 6 & 4 \\
Hemlock & 4 & 4 & 7 & 7 & 7 & 4 & 6 & 4 \\
Wetland shrub - marsh & 3 & 3 & 10 & 3 & 10 & 2 & 4 & 2 \\
Red, White, \& Jack Pine & 5 & 4 & 4 & 1 & 4 & 4 & 6 & 4 \\
NoData & $\mathrm{O}$ & $\mathrm{O}$ & $\mathrm{O}$ & $\mathrm{O}$ & $\mathrm{O}$ & $\mathrm{O}$ & 0 & 0 \\
\hline
\end{tabular}




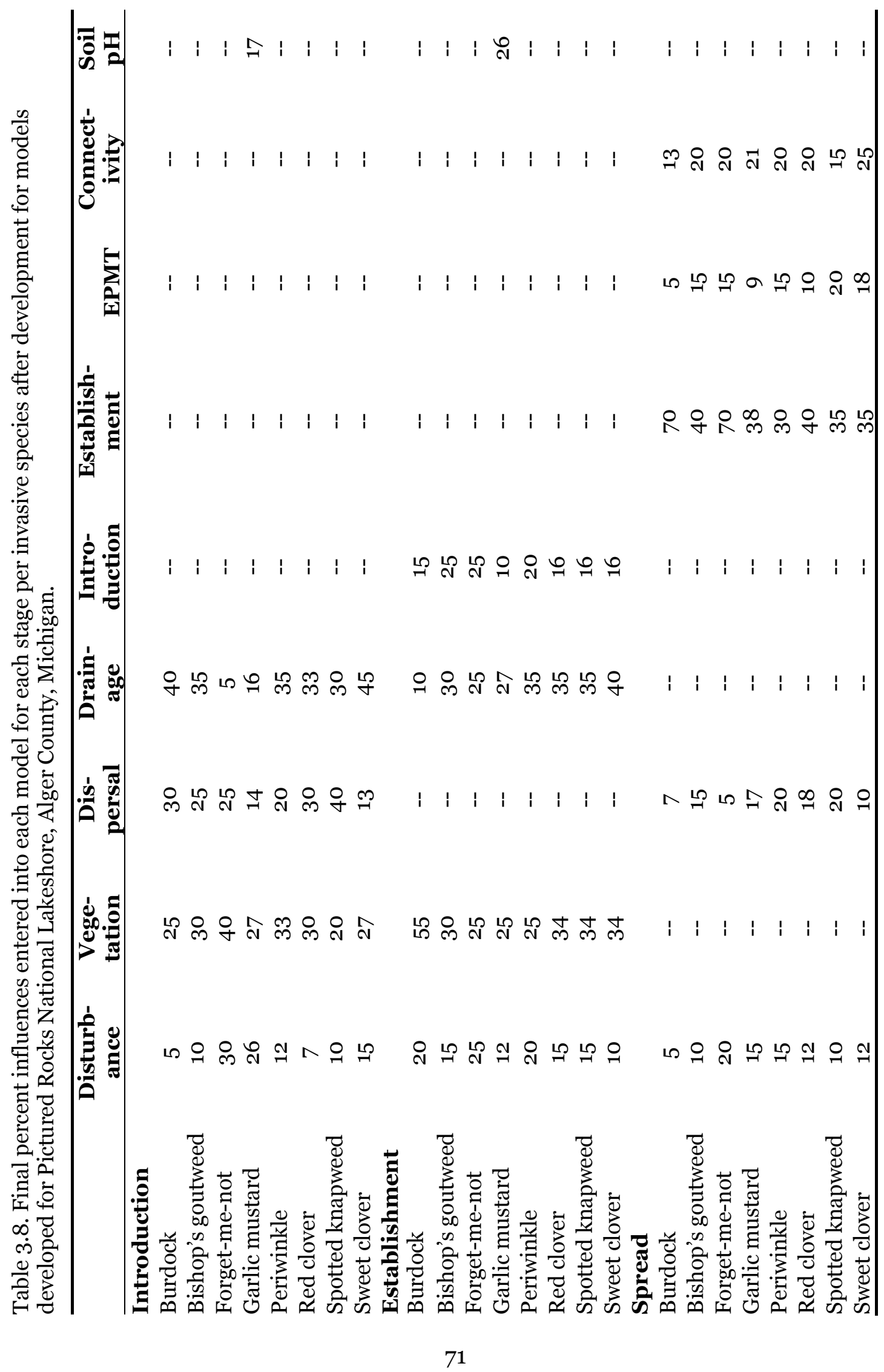


Table 3.9. Percent of invaded pixels correctly assigned a high risk (values 7-10) in PIRO for each stage of risk modeling. Values for the first run, the development dataset, and the final testing dataset are listed. * denotes values from Shartell 2007.

\section{Species}

Introduction Establishment Spread Number of Pixels

\section{First Run}

Burdock

Bishop's goutweed

$94.0 \%$

$100.0 \%$

$61.0 \%$

Forget-me-not

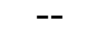

Periwinkle

$0.0 \%$

Red clover

$53.0 \%$

$77.4 \%$

$59.0 \%$

$97.0 \%$
$100.0 \%$
$52.0 \%$
--

$75.0 \%$

65

Spotted knapweed*

Sweet clover

$$
0.0 \%
$$

$57.0 \%$

10

$20.0 \%$

55

\section{Development}

\section{Burdock}

$89.2 \%$

$53.0 \%$

$99.4 \%$

$44.0 \%$

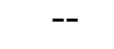

$20.0 \%$

--

Bishop's goutweed

$100.0 \%$

Forget-me-not

$56.5 \%$

Garlic mustard

Periwinkle

0.0\%

$96.2 \%$

Red clover

$78.2 \%$

$75.9 \%$
$93.9 \%$
$100.0 \%$

$46.0 \%$

2

Spotted knapweed*

Sweet clover

Final Test

\begin{tabular}{lcccc} 
Burdock & $71.0 \%$ & $77.5 \%$ & $60.0 \%$ & 138 \\
Bishop's goutweed & $96.6 \%$ & $96.6 \%$ & $100.0 \%$ & 29 \\
Forget-me-not & $83.2 \%$ & $93.6 \%$ & $91.3 \%$ & 173 \\
Garlic mustard & $100.0 \%$ & $100.0 \%$ & $100.0 \%$ & 90 \\
Periwinkle & $100.0 \%$ & $100.0 \%$ & $100.0 \%$ & 6 \\
Red clover & $94.9 \%$ & $97.1 \%$ & $96.3 \%$ & 137 \\
Spotted knapweed & $80.7 \%$ & $96.3 \%$ & $97.5 \%$ & 934 \\
Sweet clover & $89.4 \%$ & $86.5 \%$ & $87.7 \%$ & 104 \\
\hline Test Average & $89.5 \%$ & $93.4 \%$ & $91.6 \%$ &
\end{tabular}


Table 3.10. Total number of pixels and number of pixels testing for low, moderate, or high risk values for testing dataset for each model at each stage of invasion for each species. These values are valid for the eight models built for Pictured Rocks National Lakeshore in Alger County, Michigan.

\begin{tabular}{|l|c|c|c|c|c|c|}
\hline & \multicolumn{2}{|c|}{ Introduction } & \multicolumn{2}{c|}{ Establishment } & \multicolumn{2}{c|}{ Spread } \\
\hline Species & Risk & Total & Risk & Total & Risk & Total \\
\hline Burdock & 98 & 138 & 107 & 138 & 36 & 60 \\
\hline Bishop's Goutweed & 28 & 29 & 28 & 29 & 9 & 9 \\
\hline Forget-me-not & 353 & 526 & 405 & 578 & 132 & 201 \\
\hline Garlic mustard & 90 & 90 & 90 & 90 & 90 & 90 \\
\hline Periwinkle & 2 & 2 & 5 & 5 & 2 & 2 \\
\hline Red clover & 130 & 137 & 133 & 137 & 105 & 109 \\
\hline Spotted knapweed & 613 & 760 & 732 & 760 & 723 & 934 \\
\hline Sweet clover & 90 & 104 & 96 & 107 & 57 & 57 \\
\hline
\end{tabular}




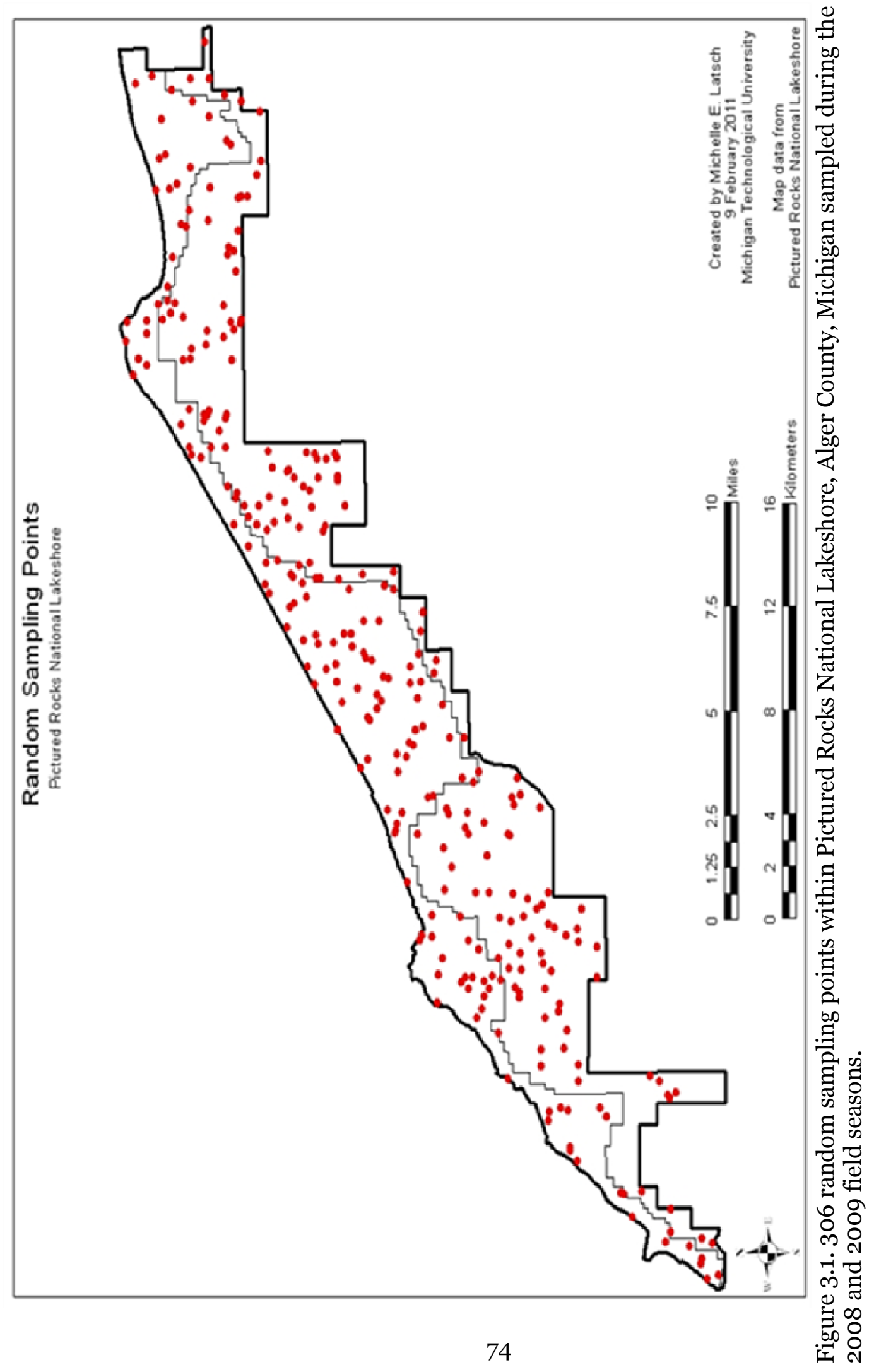




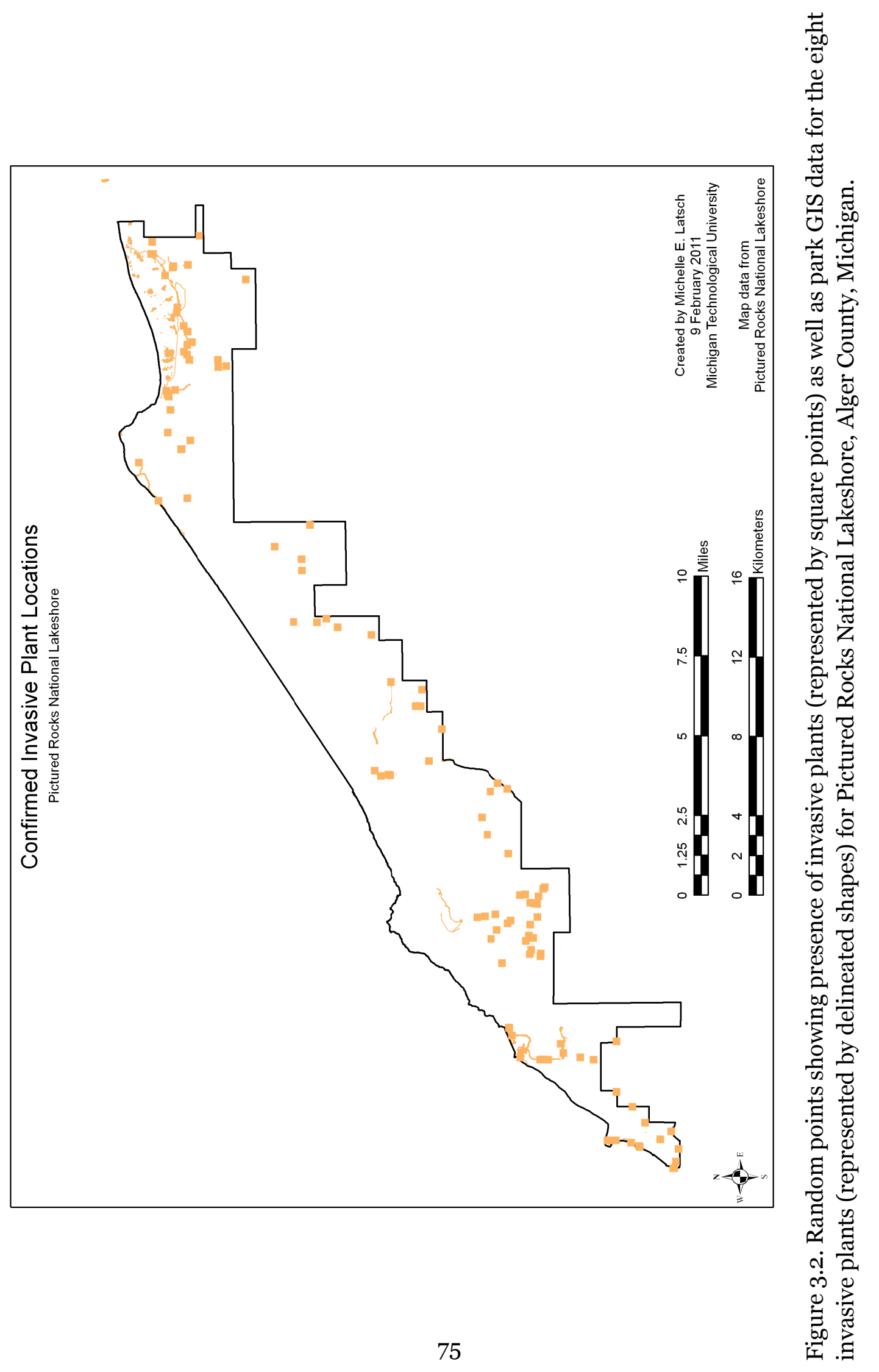




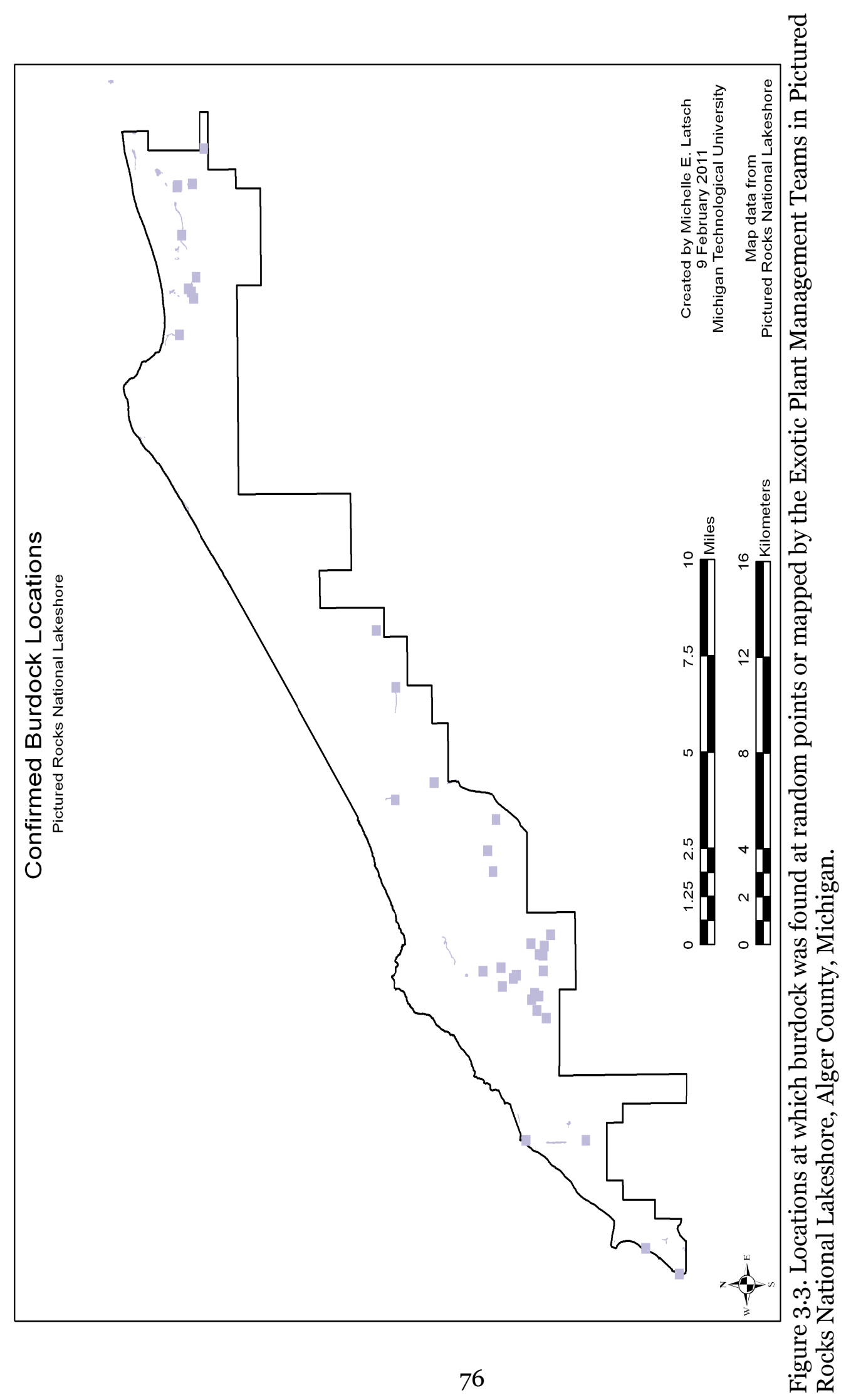




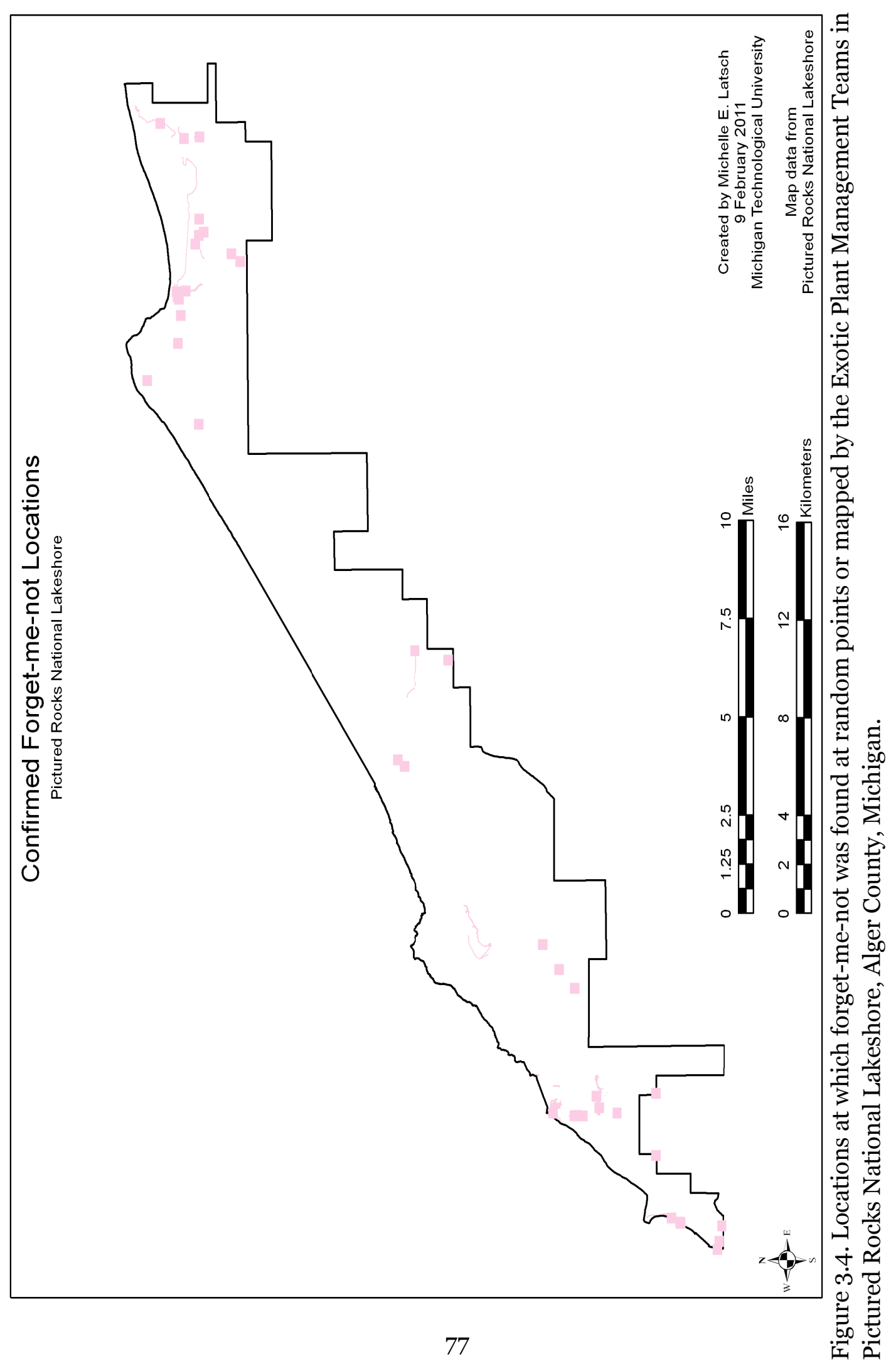




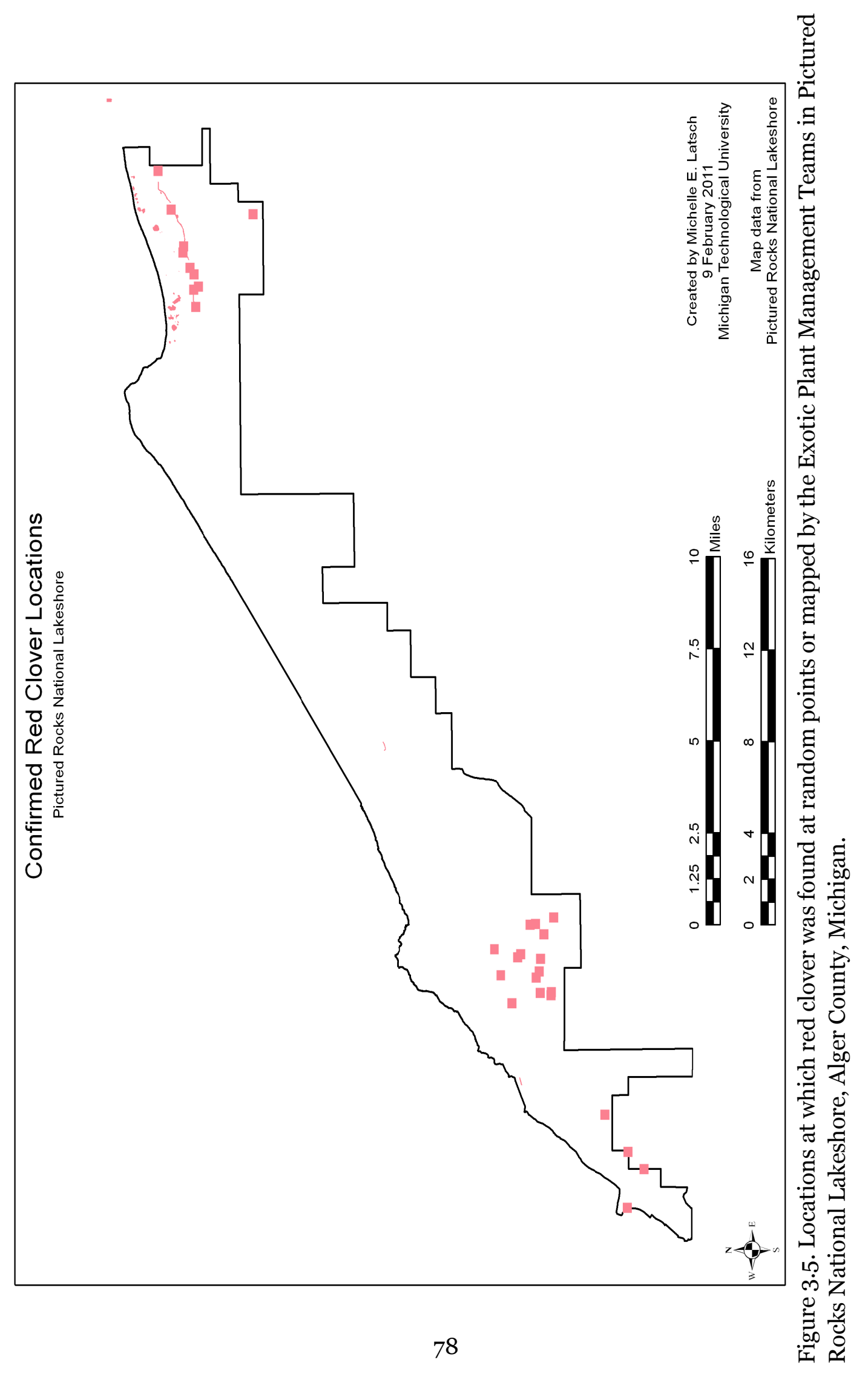




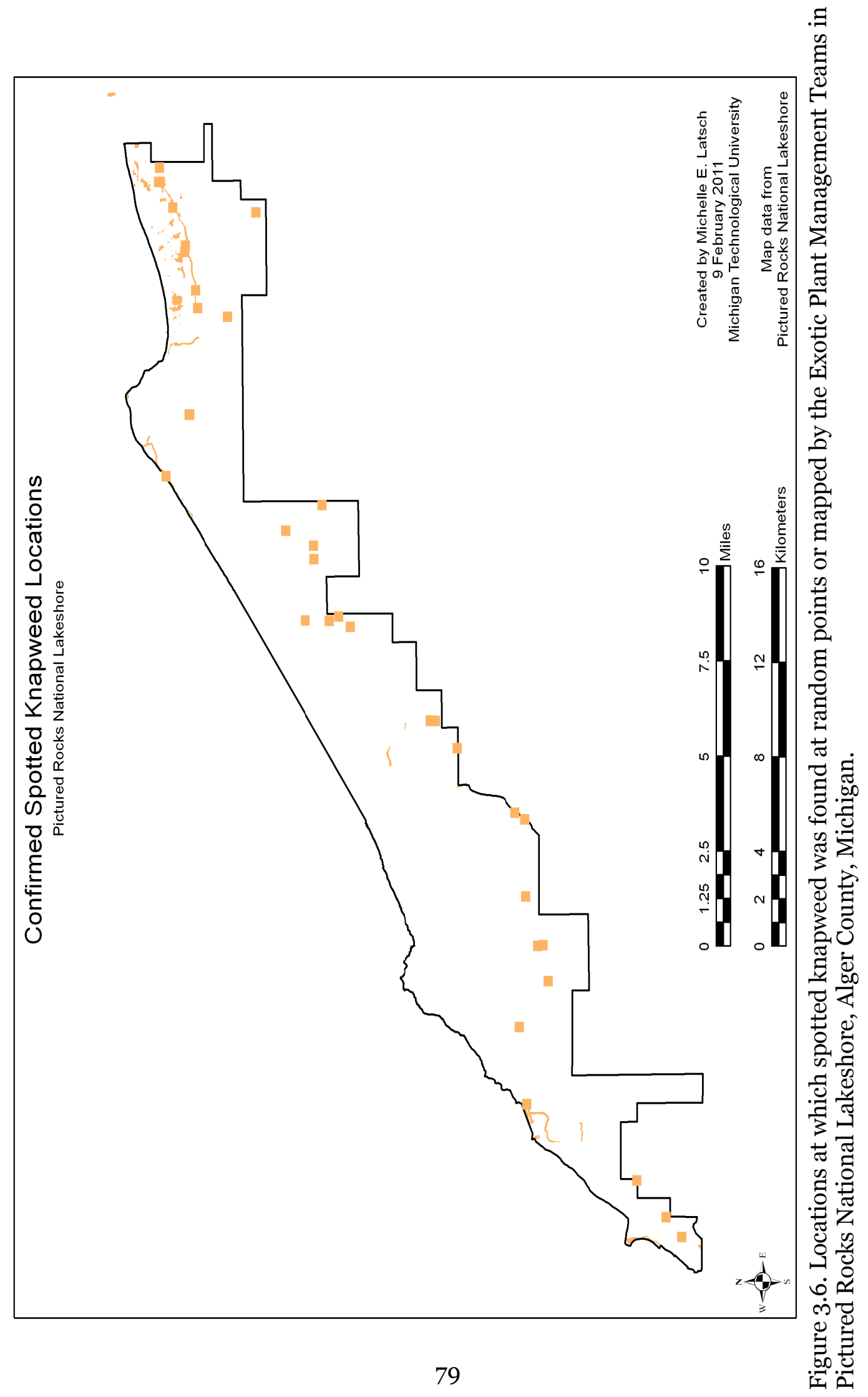




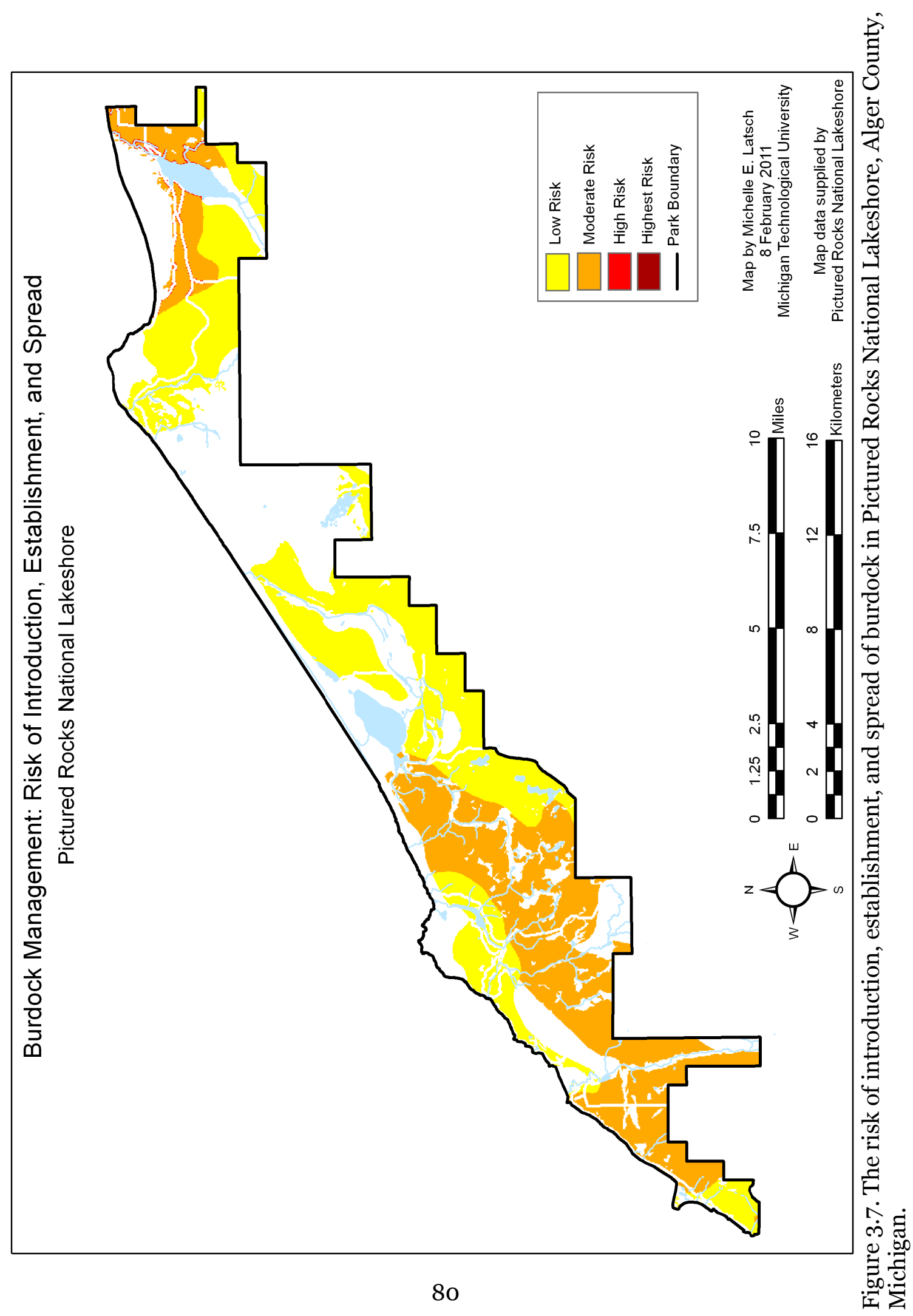




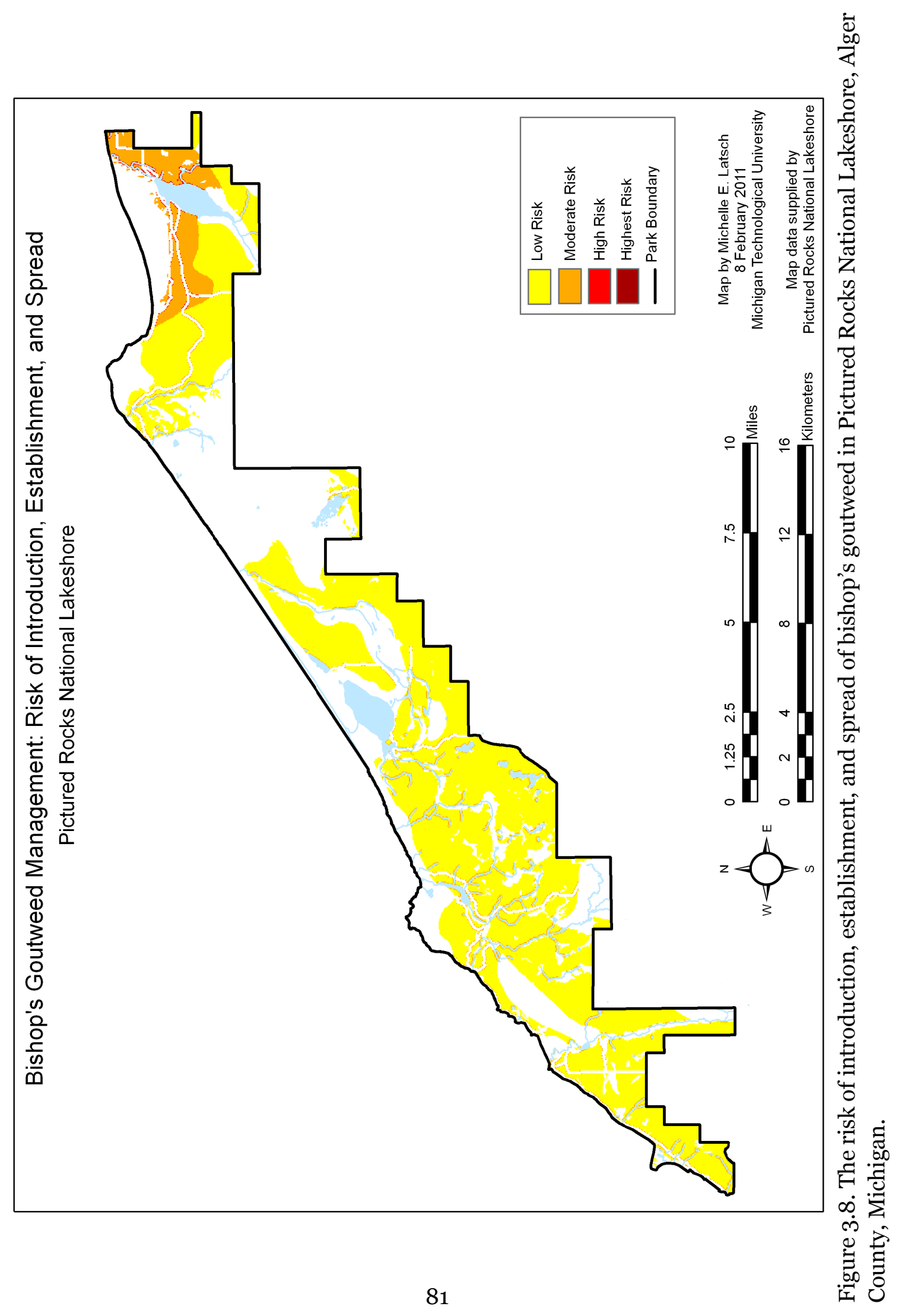




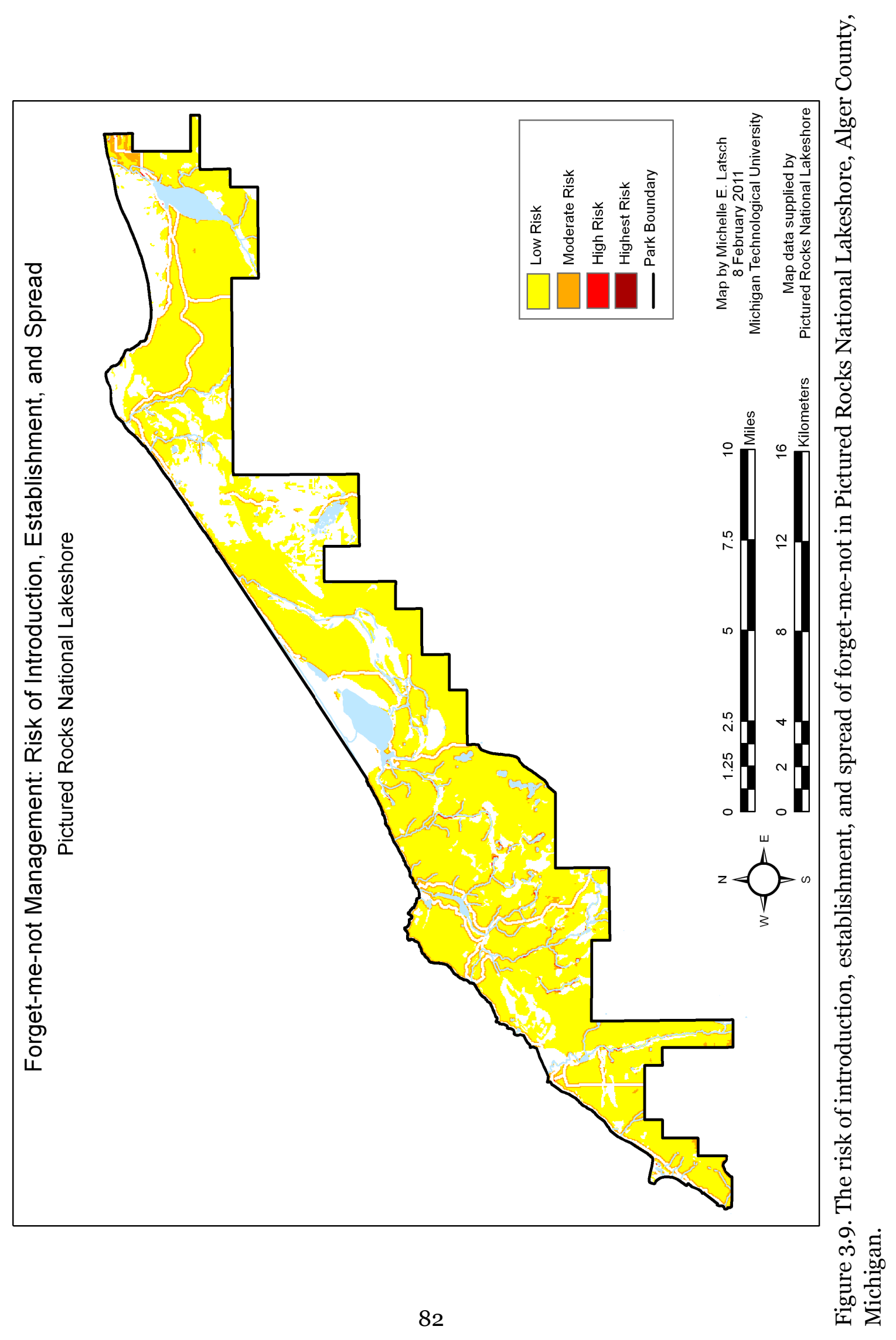




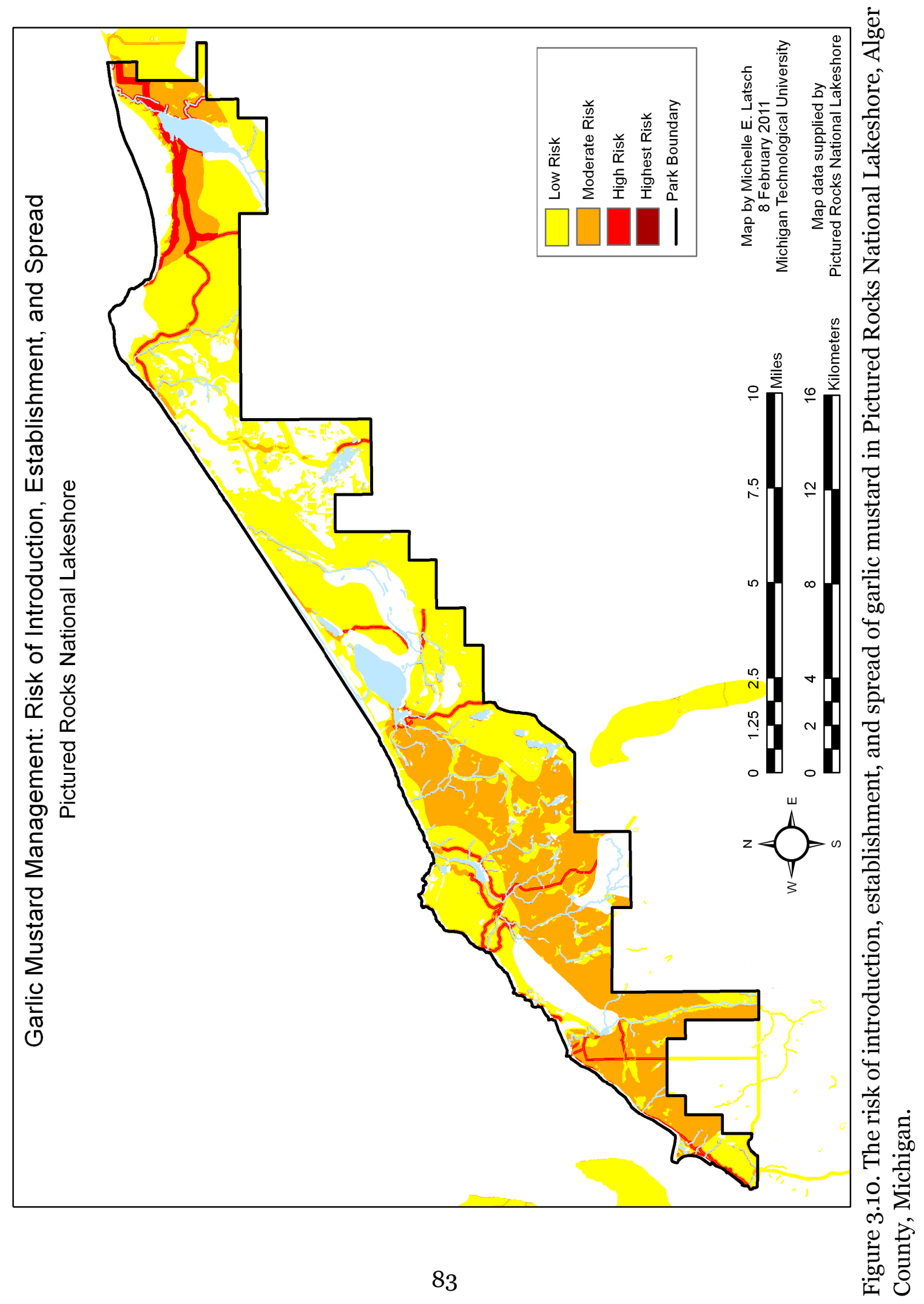




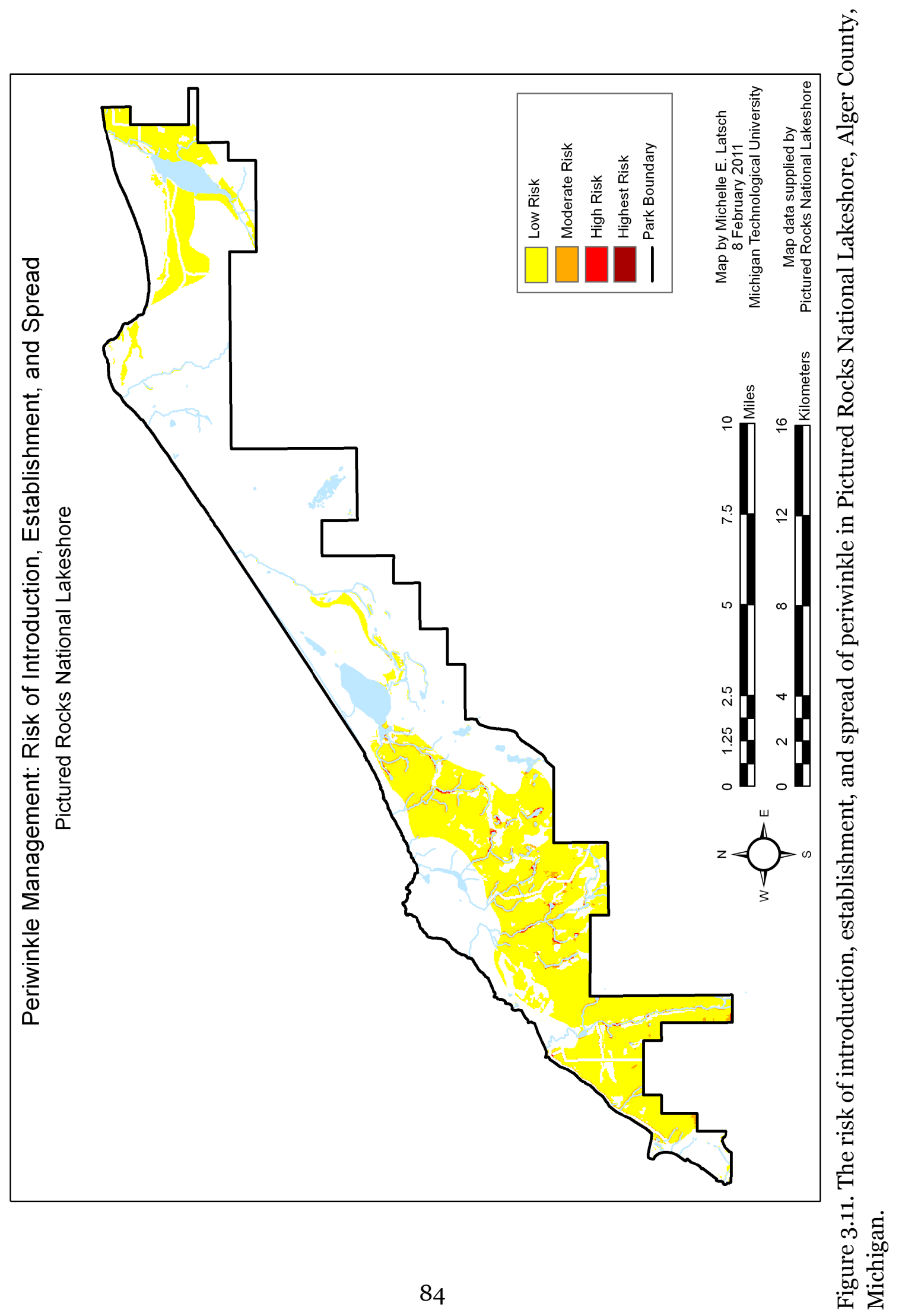




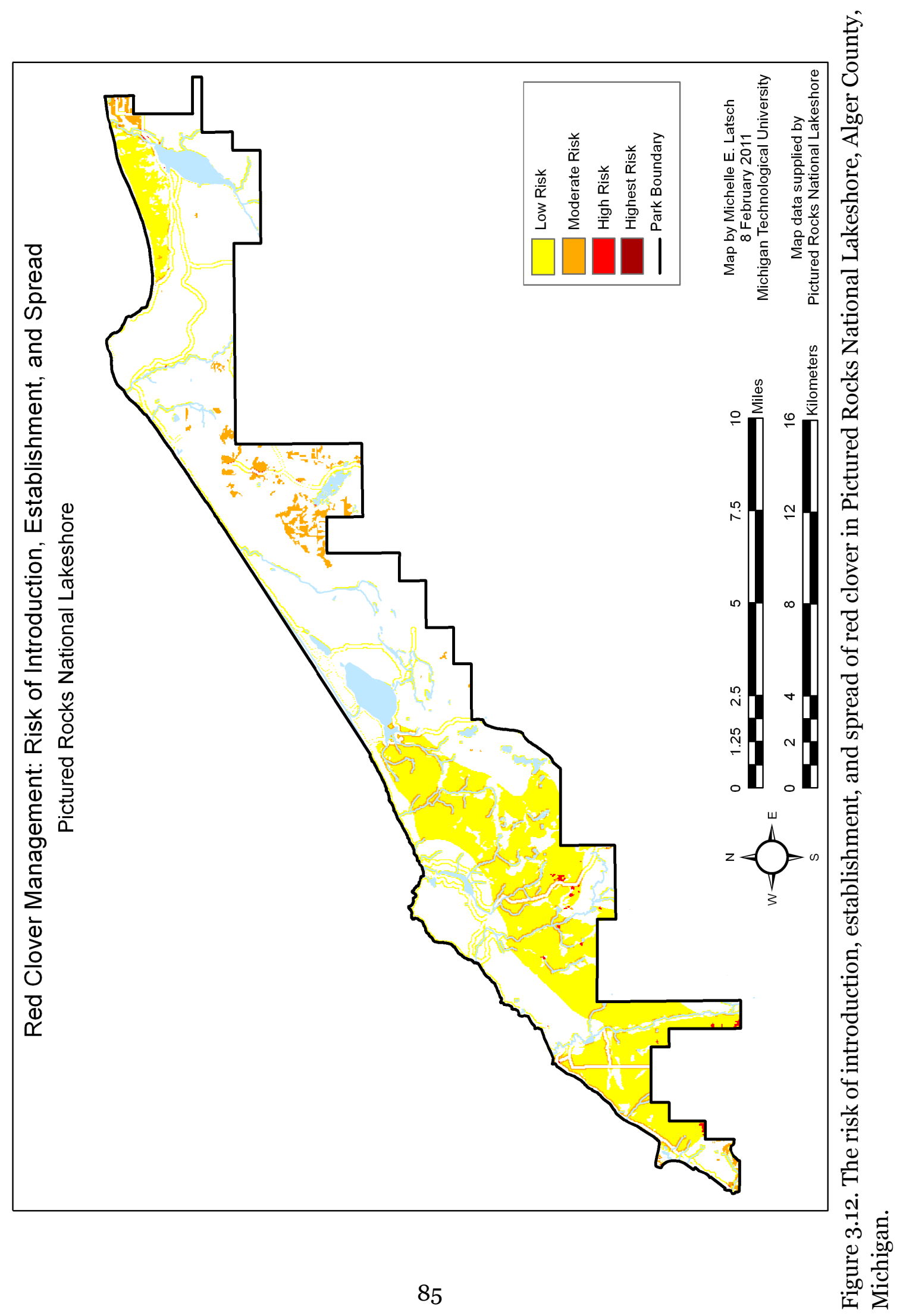




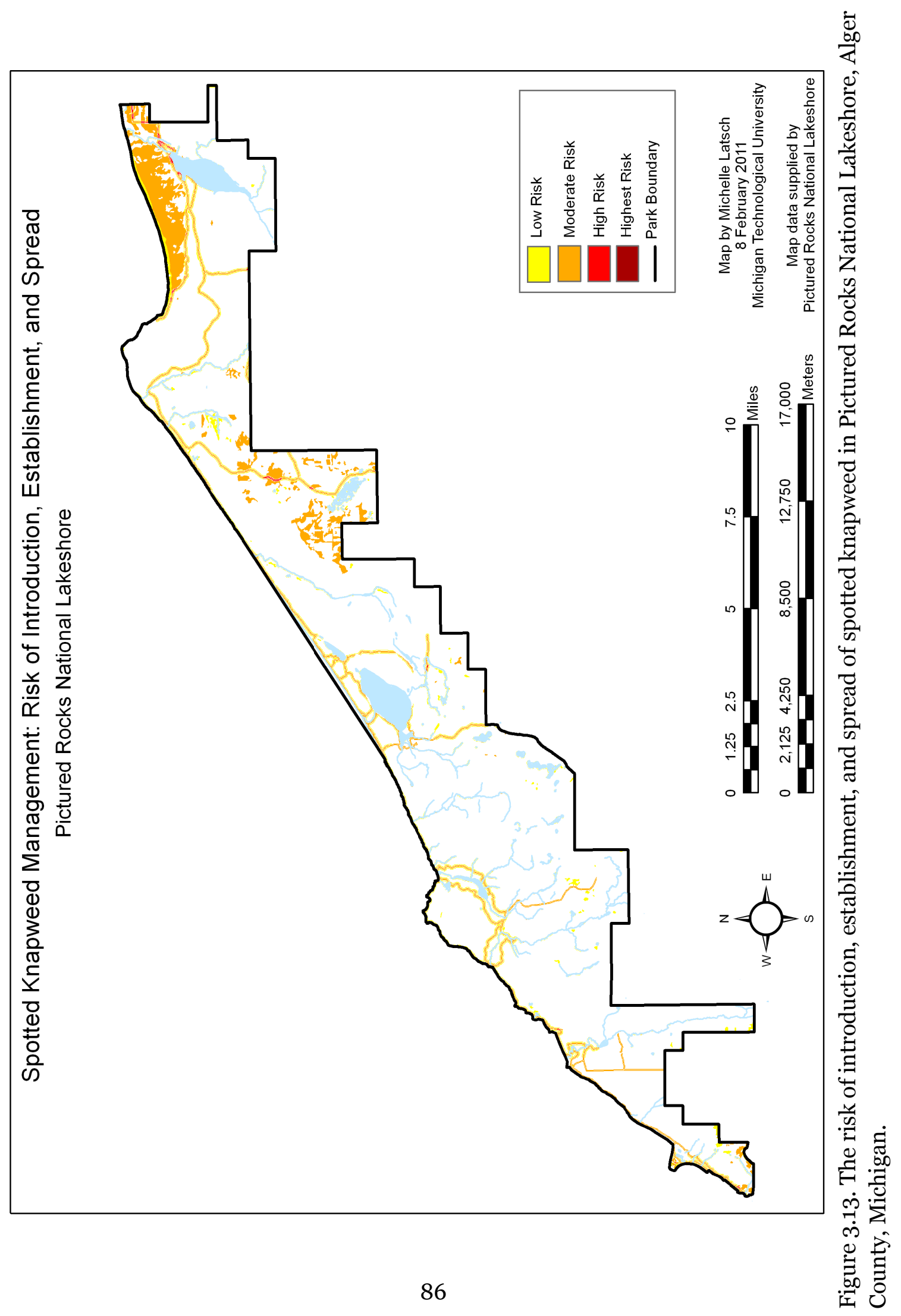




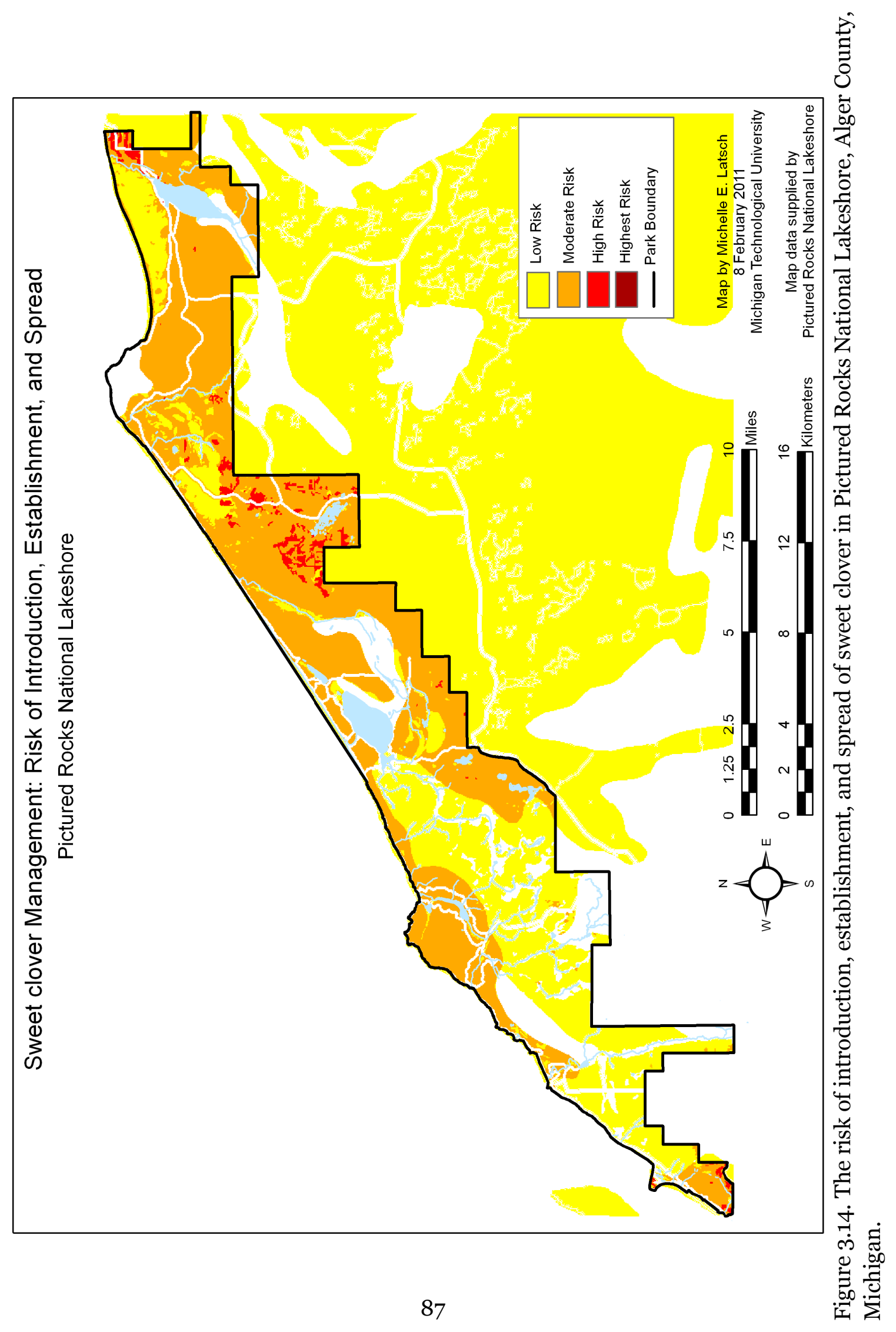


Table 3.11. Descriptions for model layouts.

\begin{tabular}{|c|l|}
\hline $\begin{array}{c}\text { Soil Feature } \\
\text { to Raster }\end{array}$ & $\begin{array}{l}\text { Description } \\
\text { Yellow squares are the ArcGIS tools that perform an action on } \\
\text { model components. }\end{array}$ \\
\hline $\begin{array}{c}\text { Soil } \\
\text { Deatures }\end{array}$ & $\begin{array}{l}\text { Green ovals are output layers resulting from the actions } \\
\text { performed on model parameters or other output layers. }\end{array}$ \\
\hline $\begin{array}{c}\text { Soil } \\
\text { Drainage }\end{array}$ & $\begin{array}{l}\text { Darker blue ovals with associated "P" are model parameters, } \\
\text { which allow the user to enter datasets to be processed. This is } \\
\text { where the GIS layers like soils, hydrology, or vegetation are } \\
\text { loaded. }\end{array}$ \\
\hline $\begin{array}{l}\text { Lighter blue ovals with associated "P" are model parameters, } \\
\text { which allow the user to enter datasets to be processed. These } \\
\text { identify the specific field of the associated parameter to be } \\
\text { processed. }\end{array}$ \\
\hline
\end{tabular}




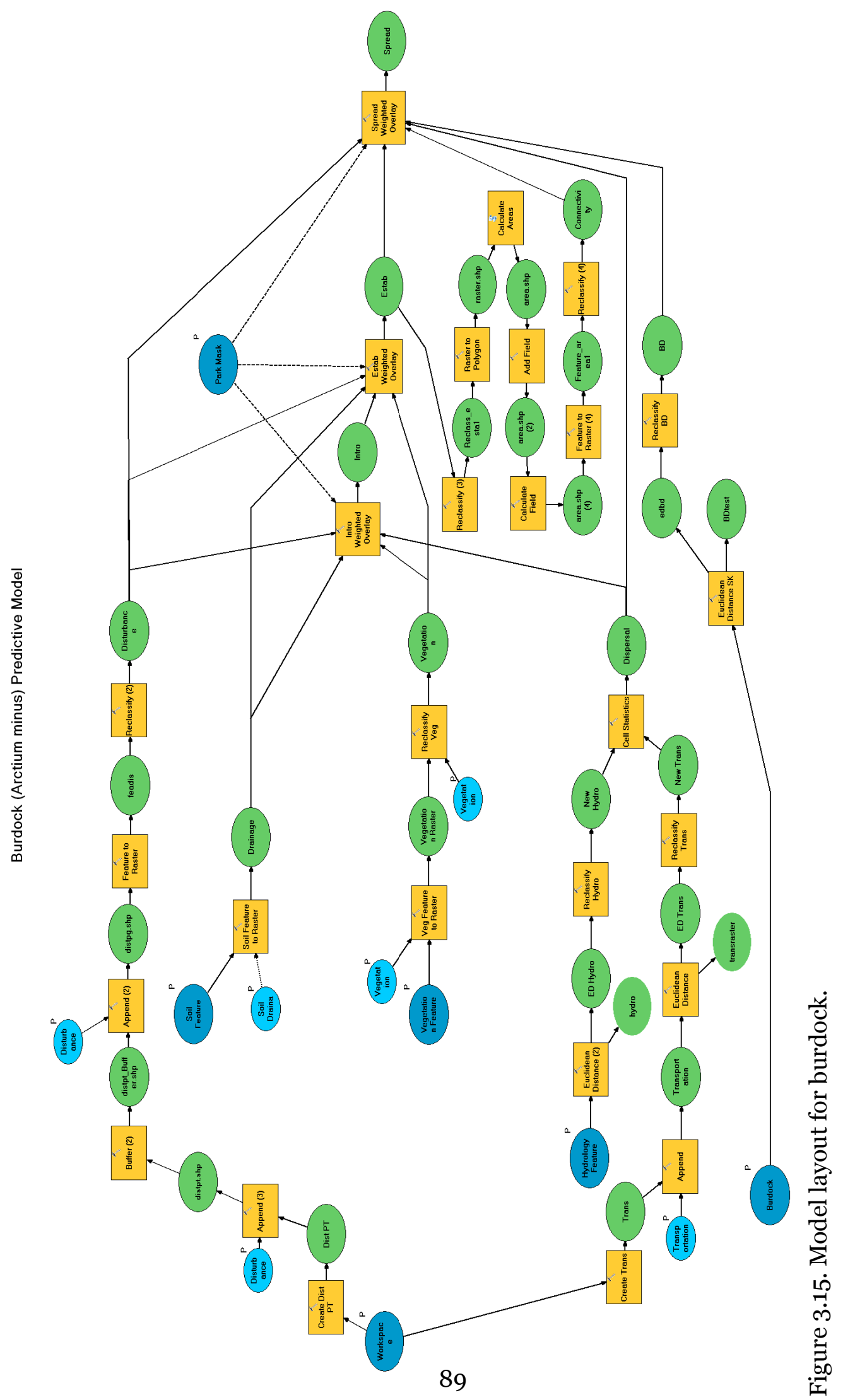




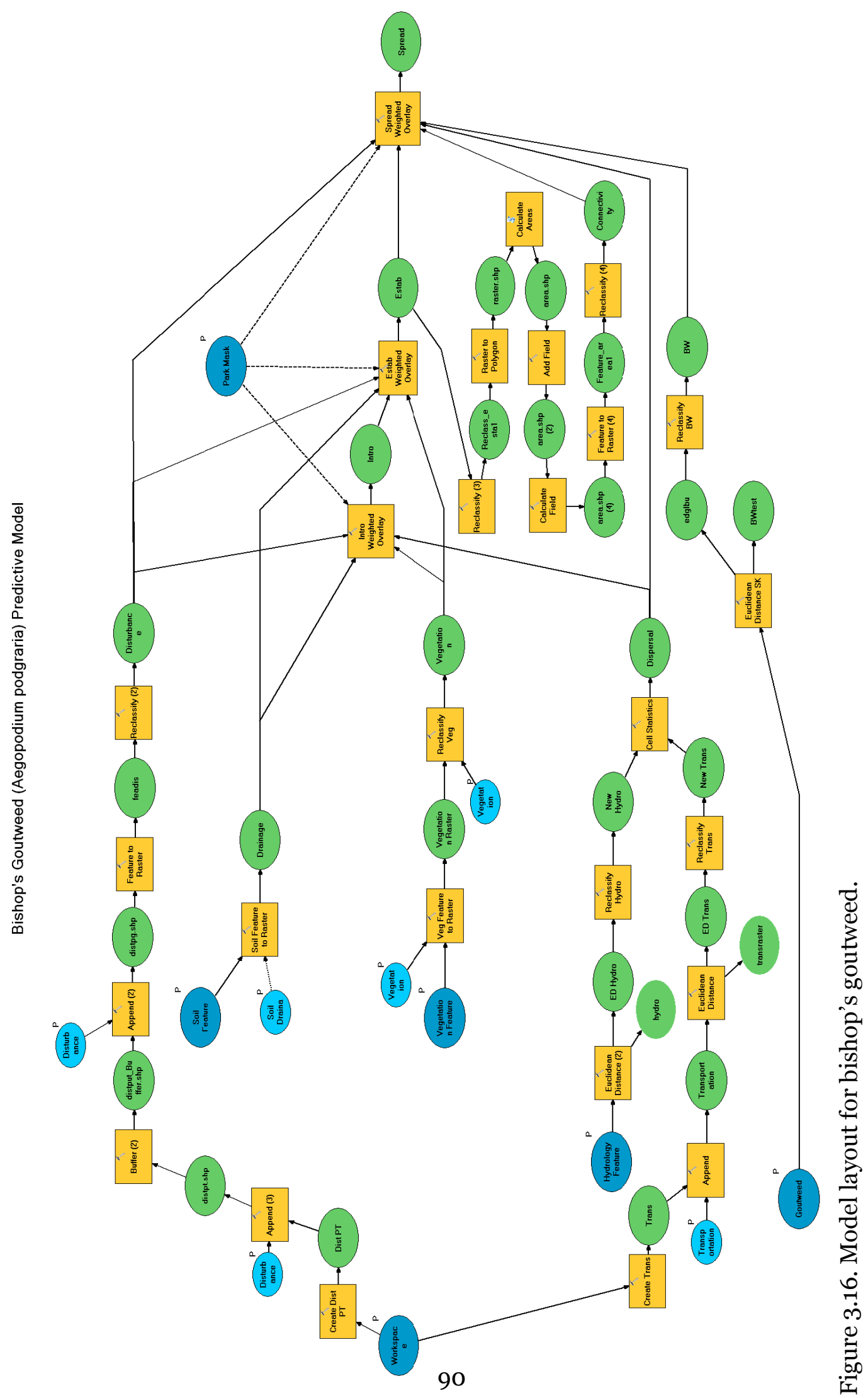




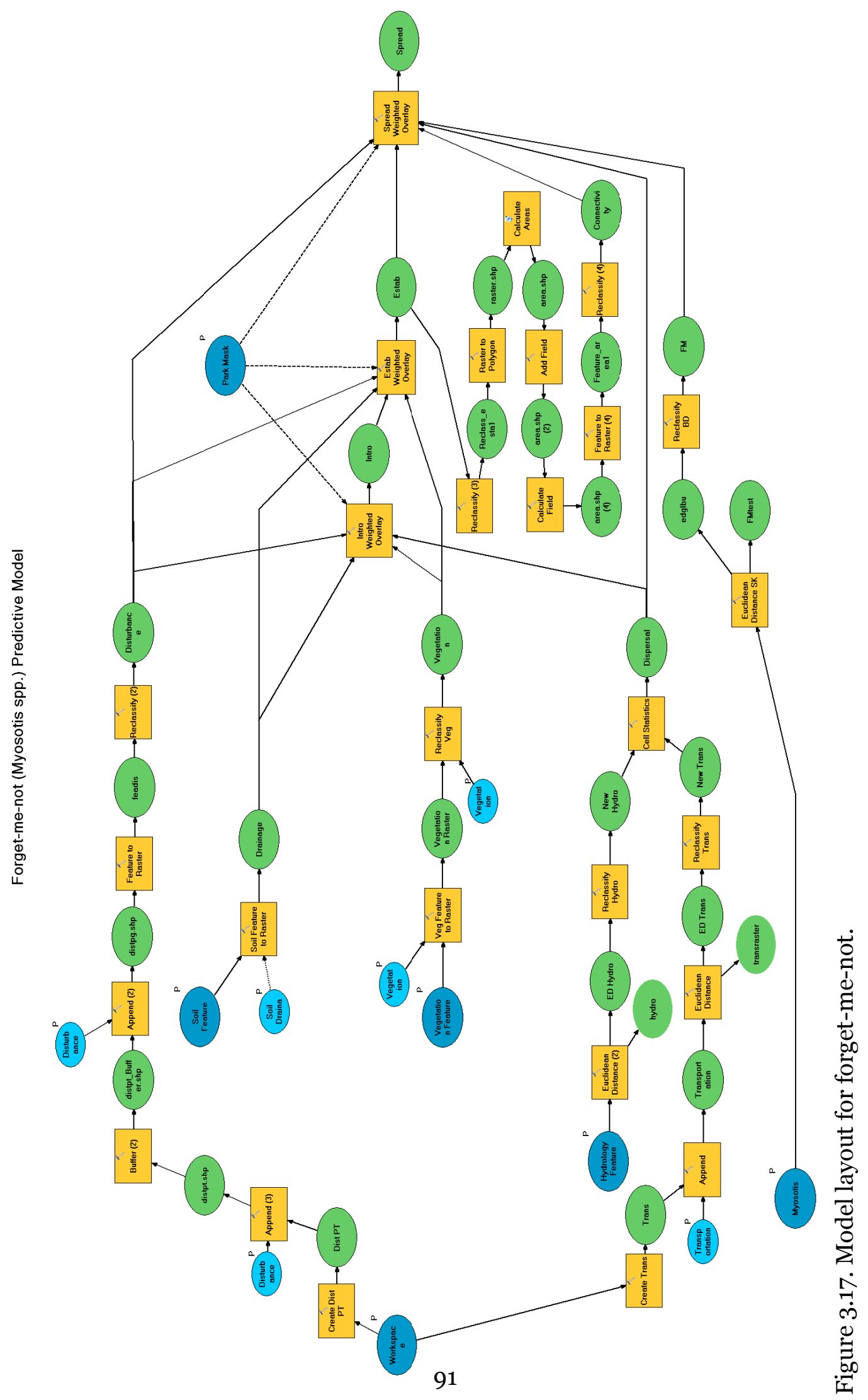




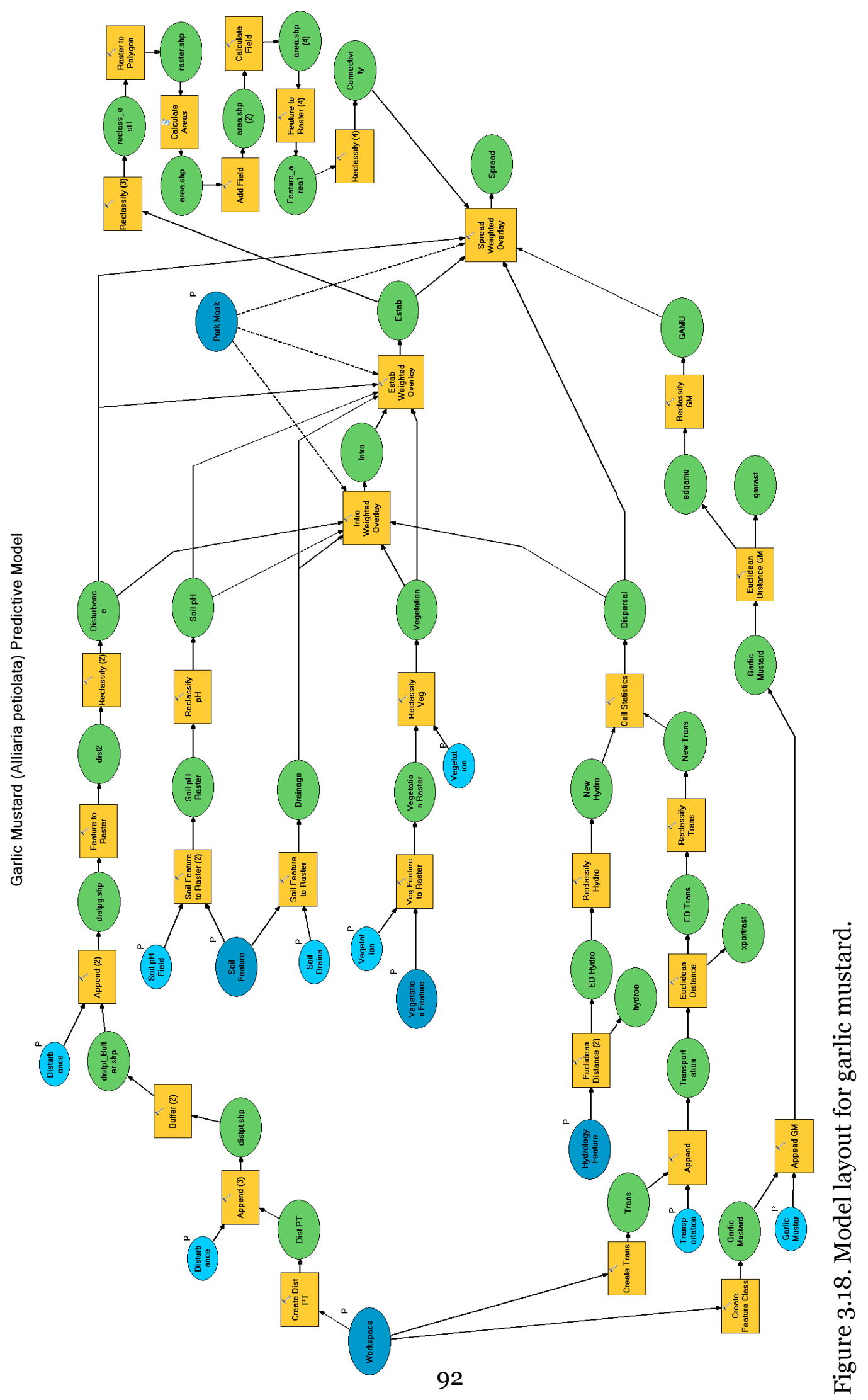




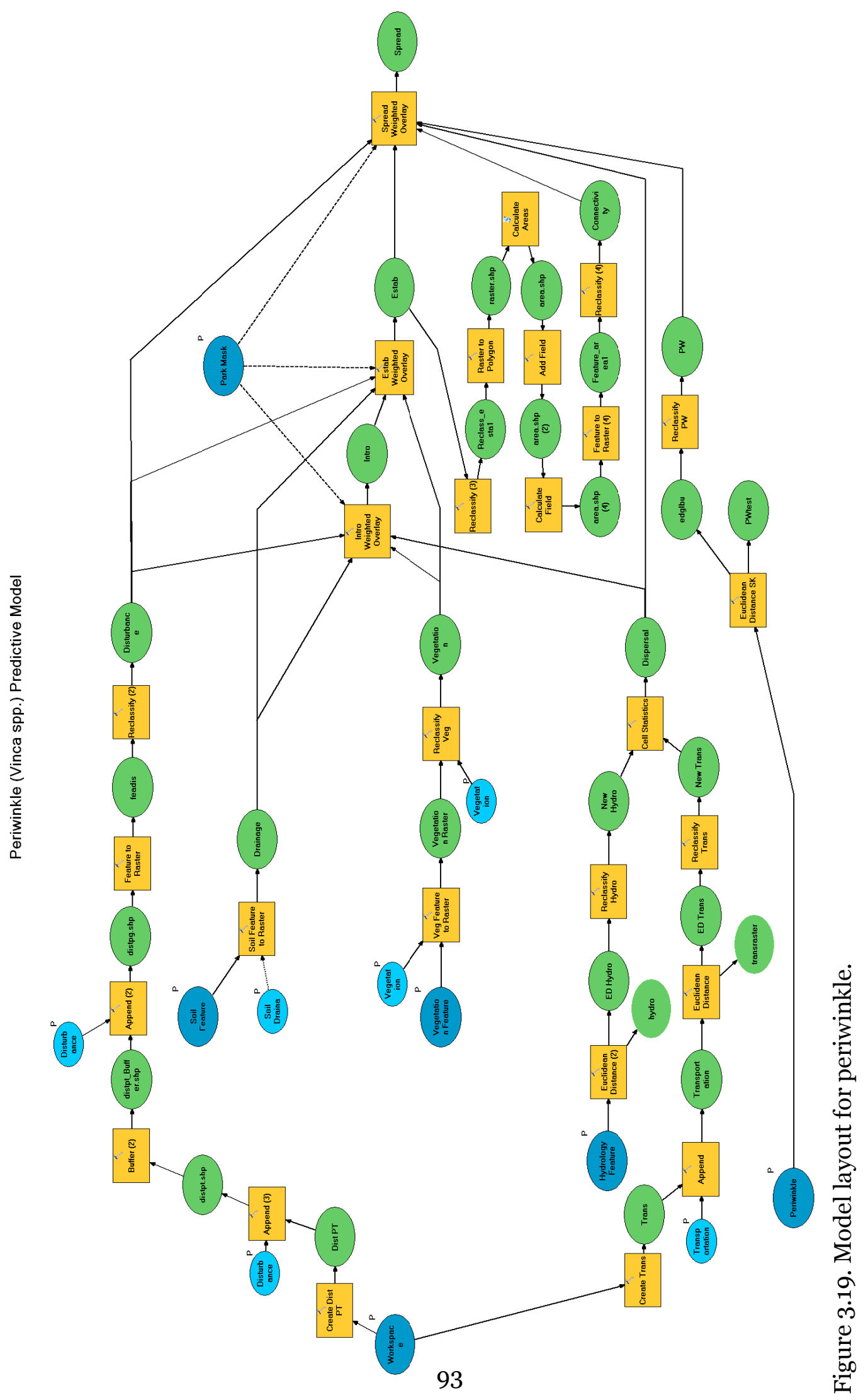




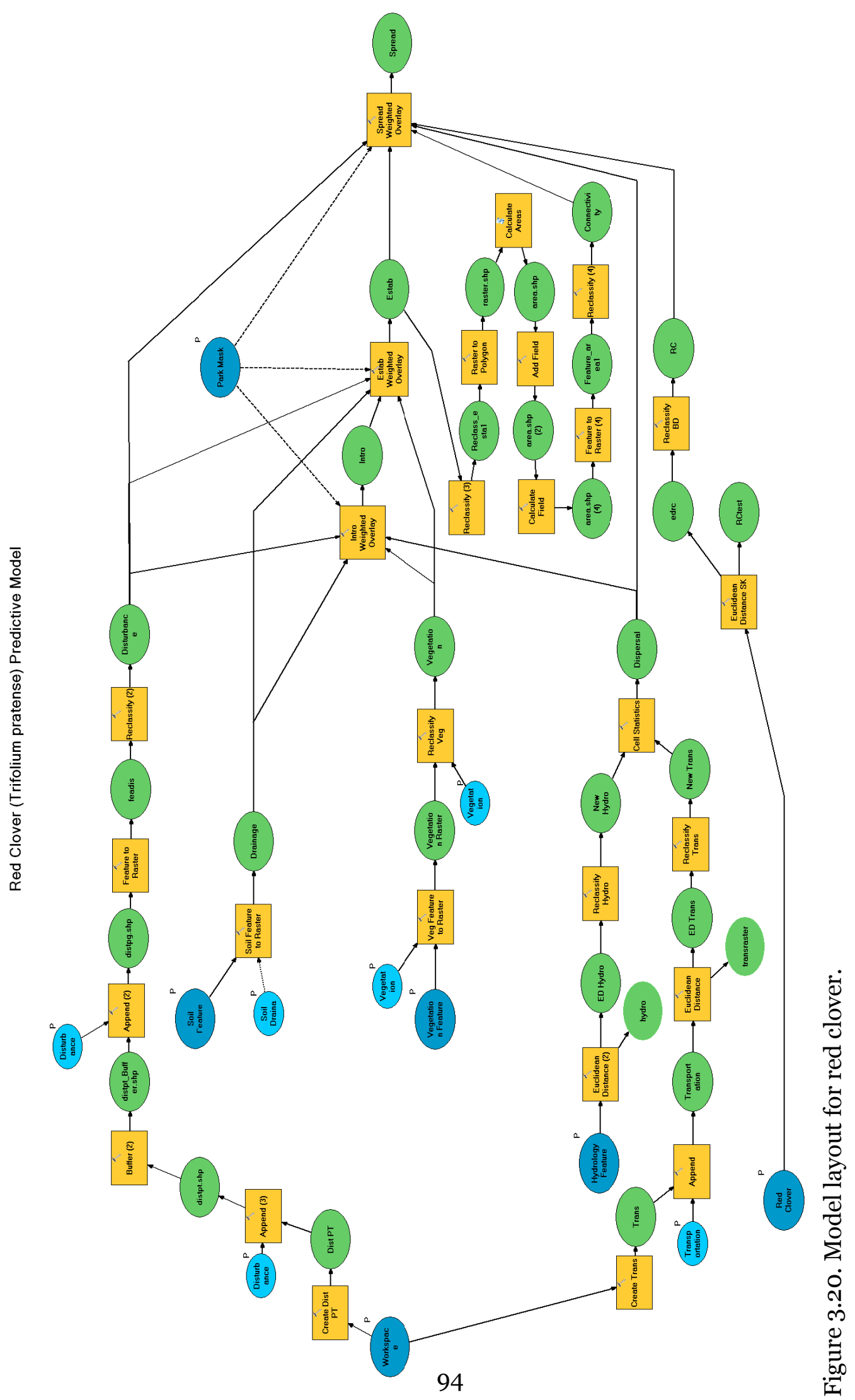




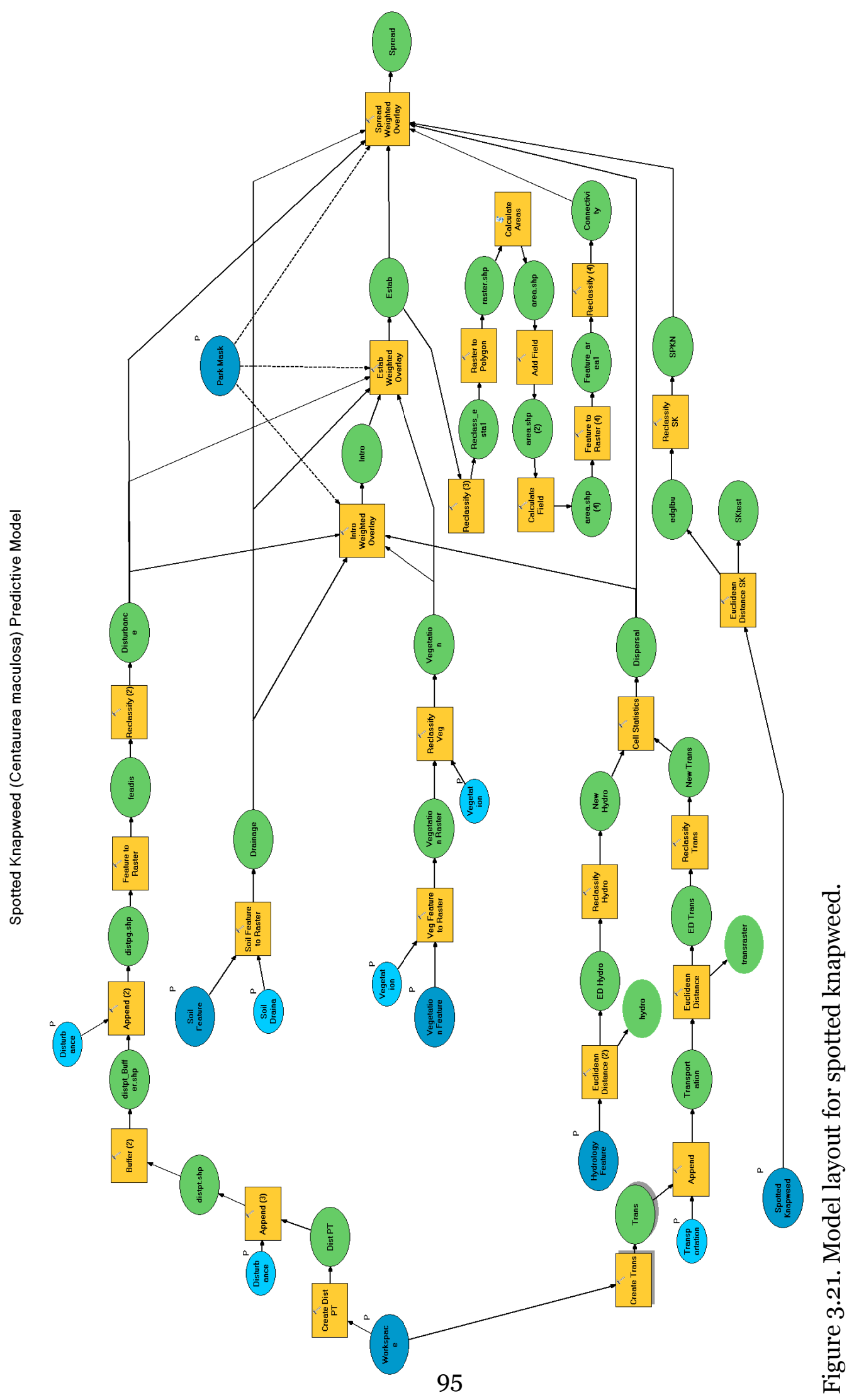




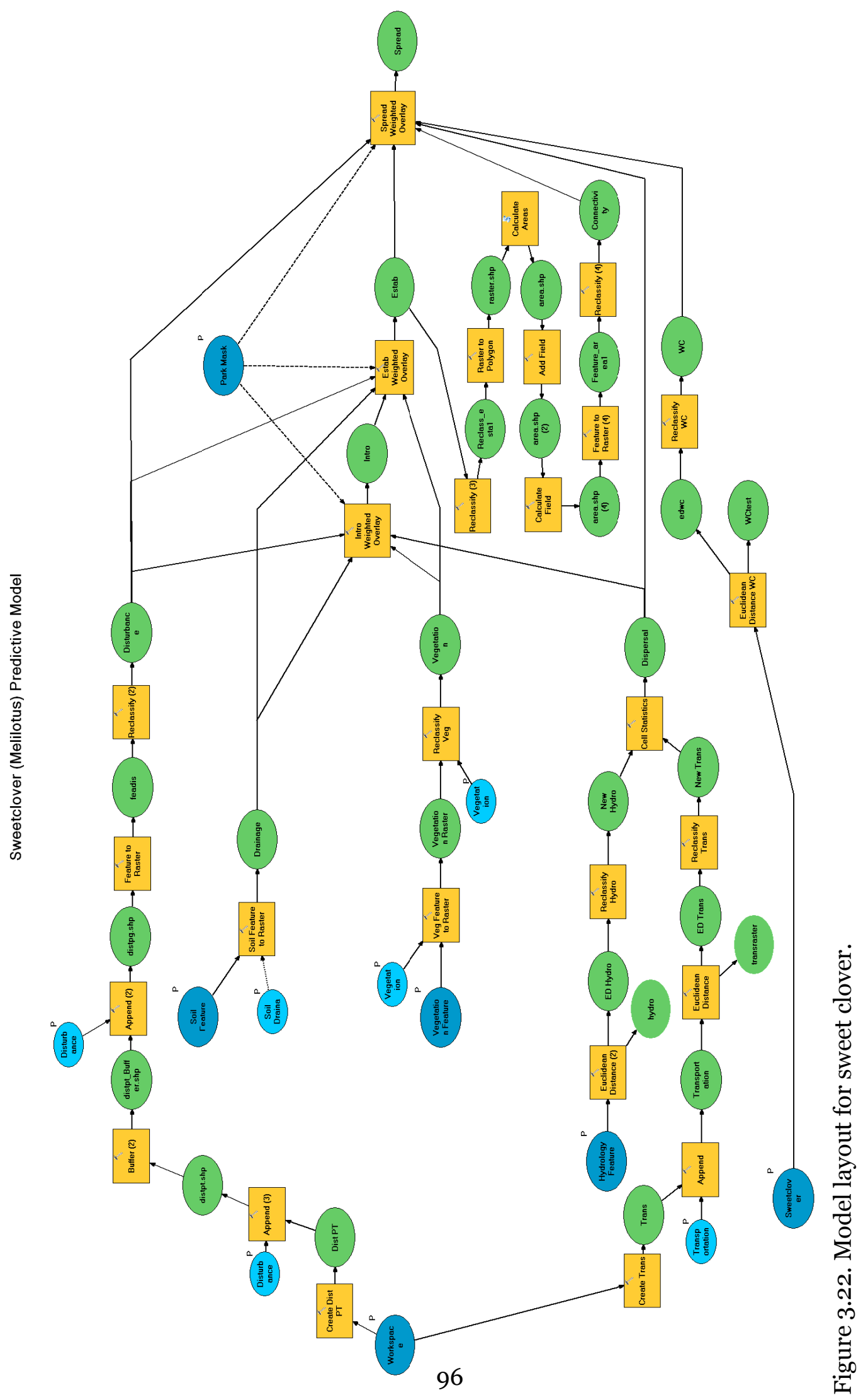




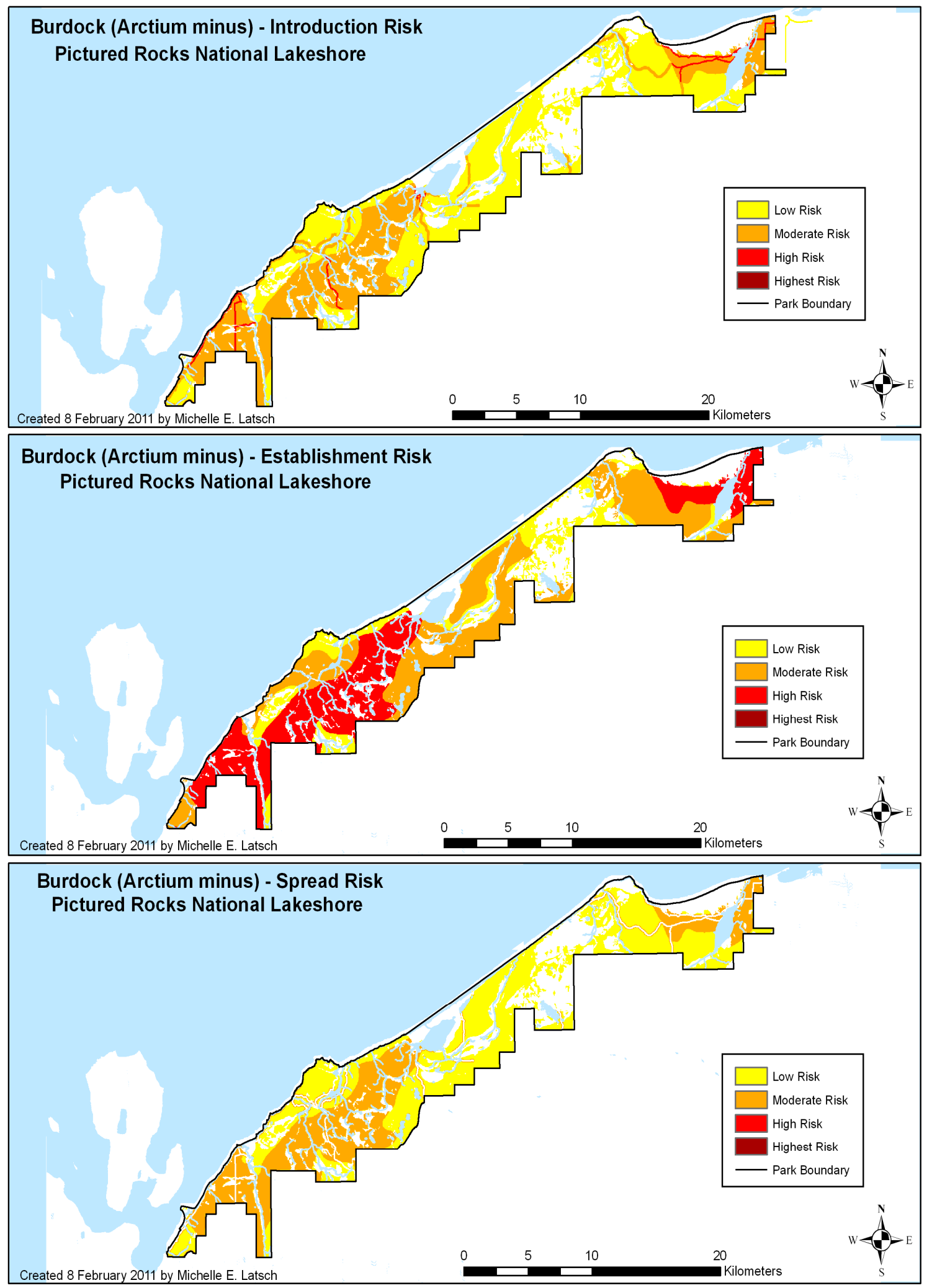

Figure 3.23. Output map for introduction, establishment, and spread of burdock. 

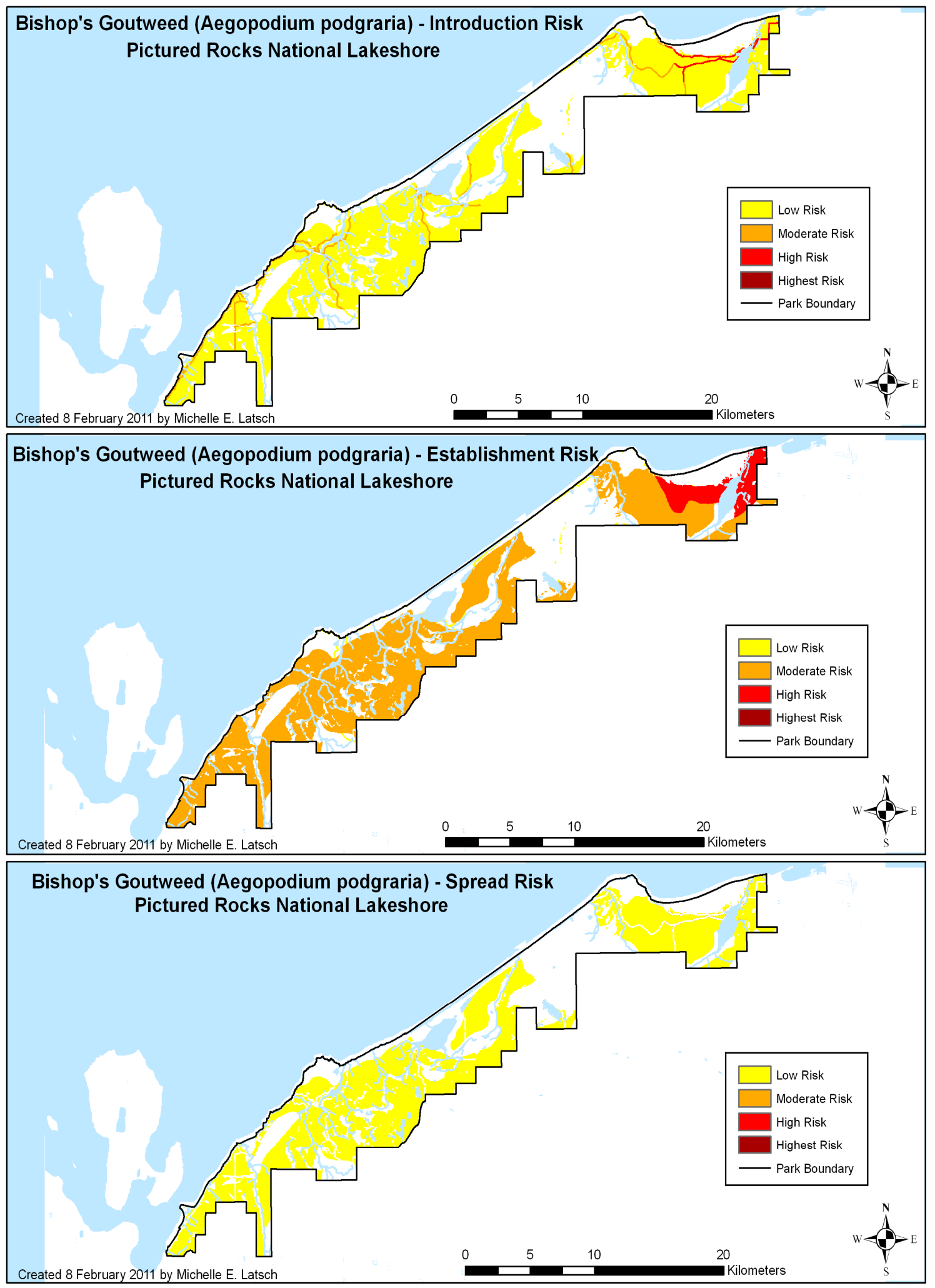

Figure 3.24. Output map for introduction, establishment, and spread of bishop's goutweed. 

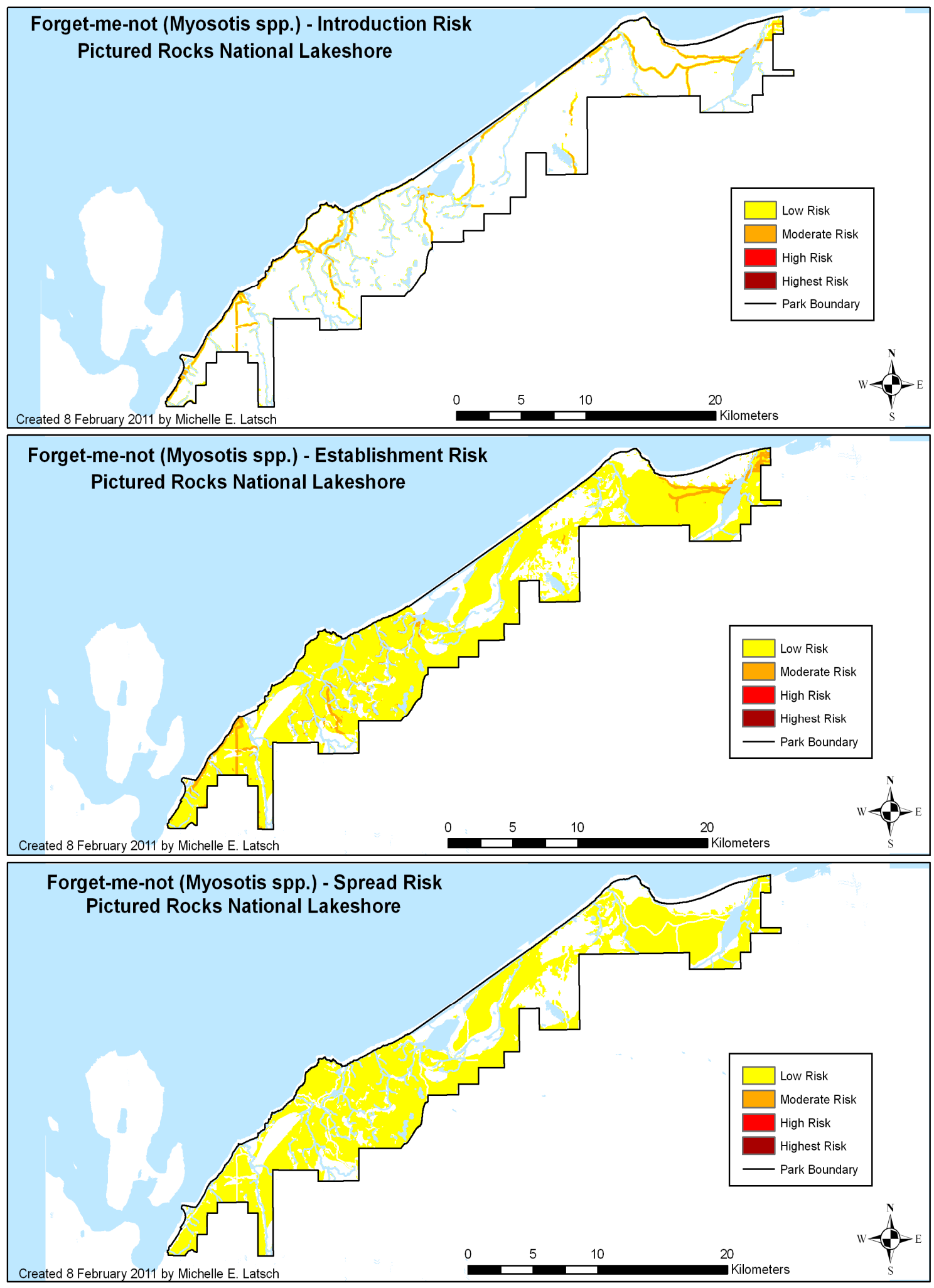

Figure 3.25. Output map for introduction, establishment, and spread of forget-me-not. 


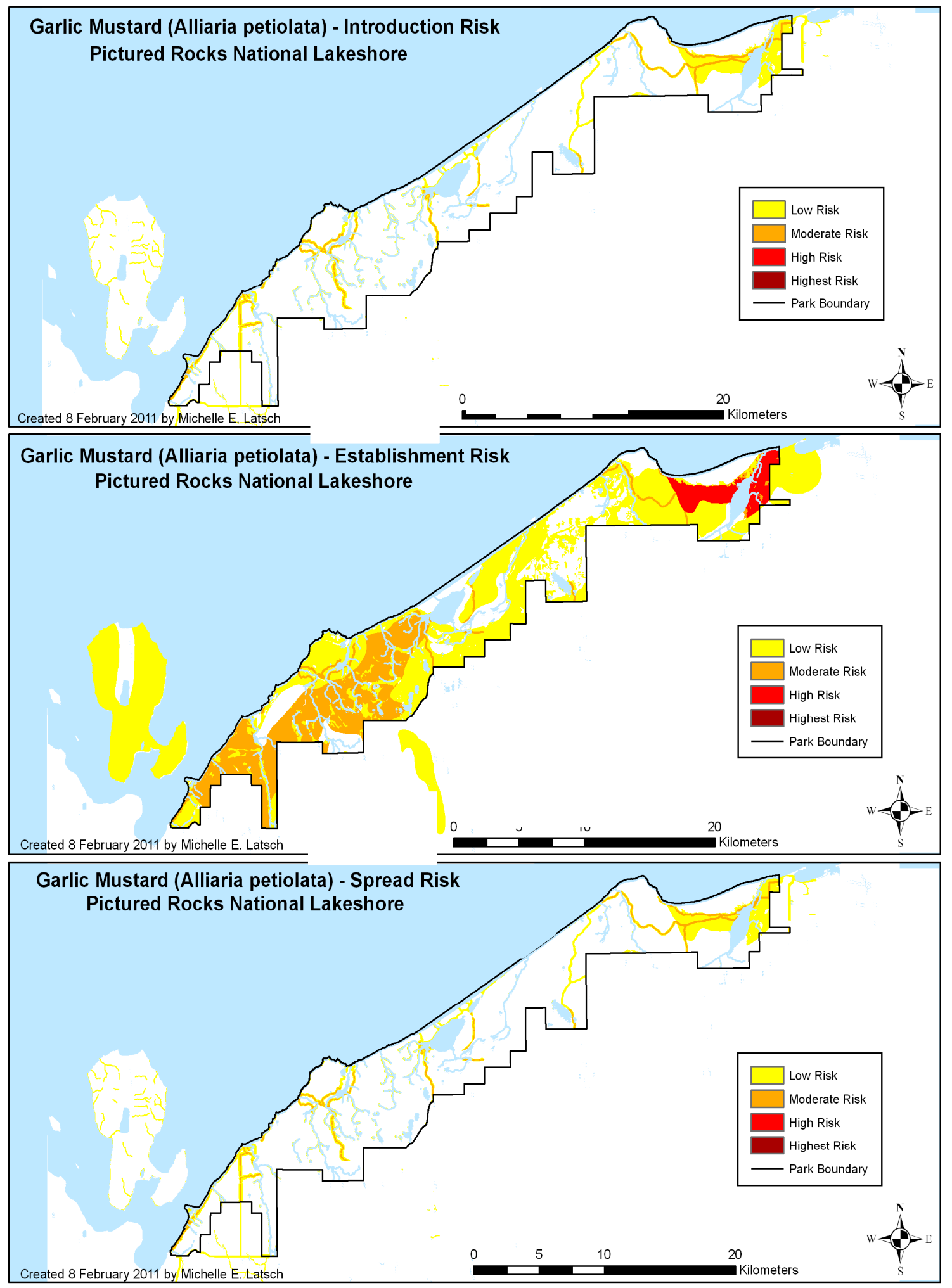

Figure 3.26. Output map for introduction, establishment, and spread of garlic mustard. 


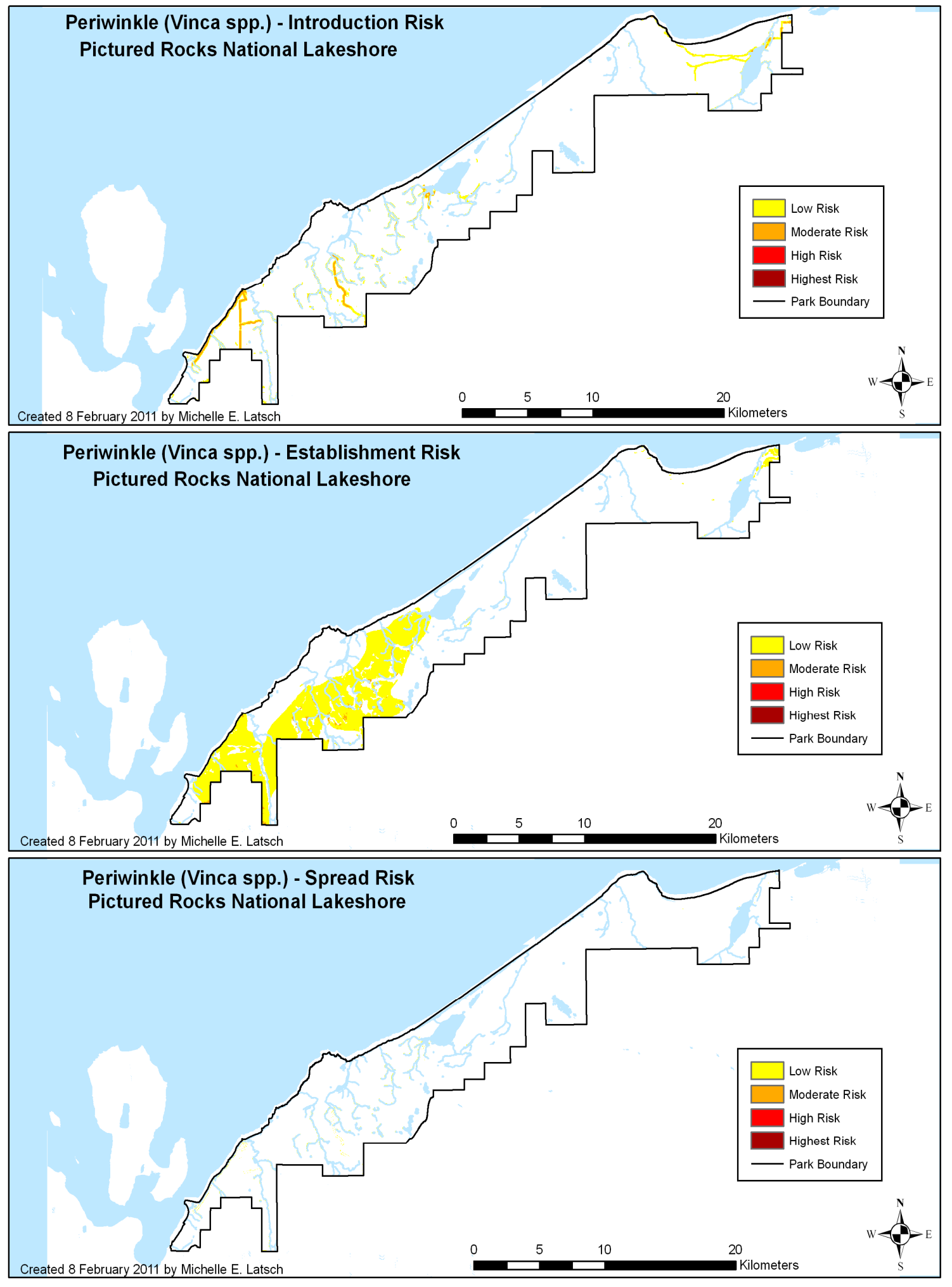

Figure 3.27. Output map for introduction, establishment, and spread of periwinkle. 

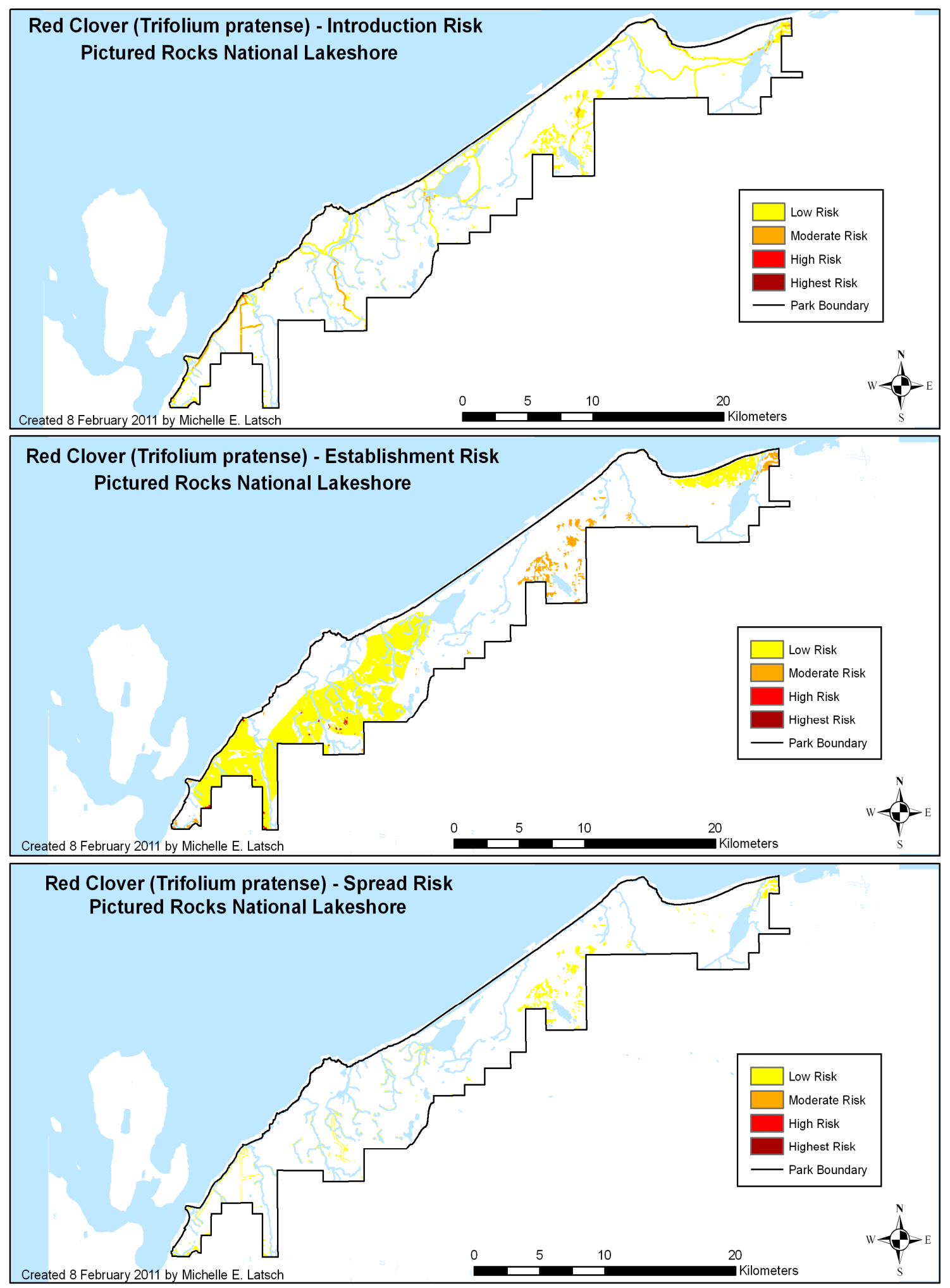

Figure 3.28. Output map for introduction, establishment, and spread of red clover. 

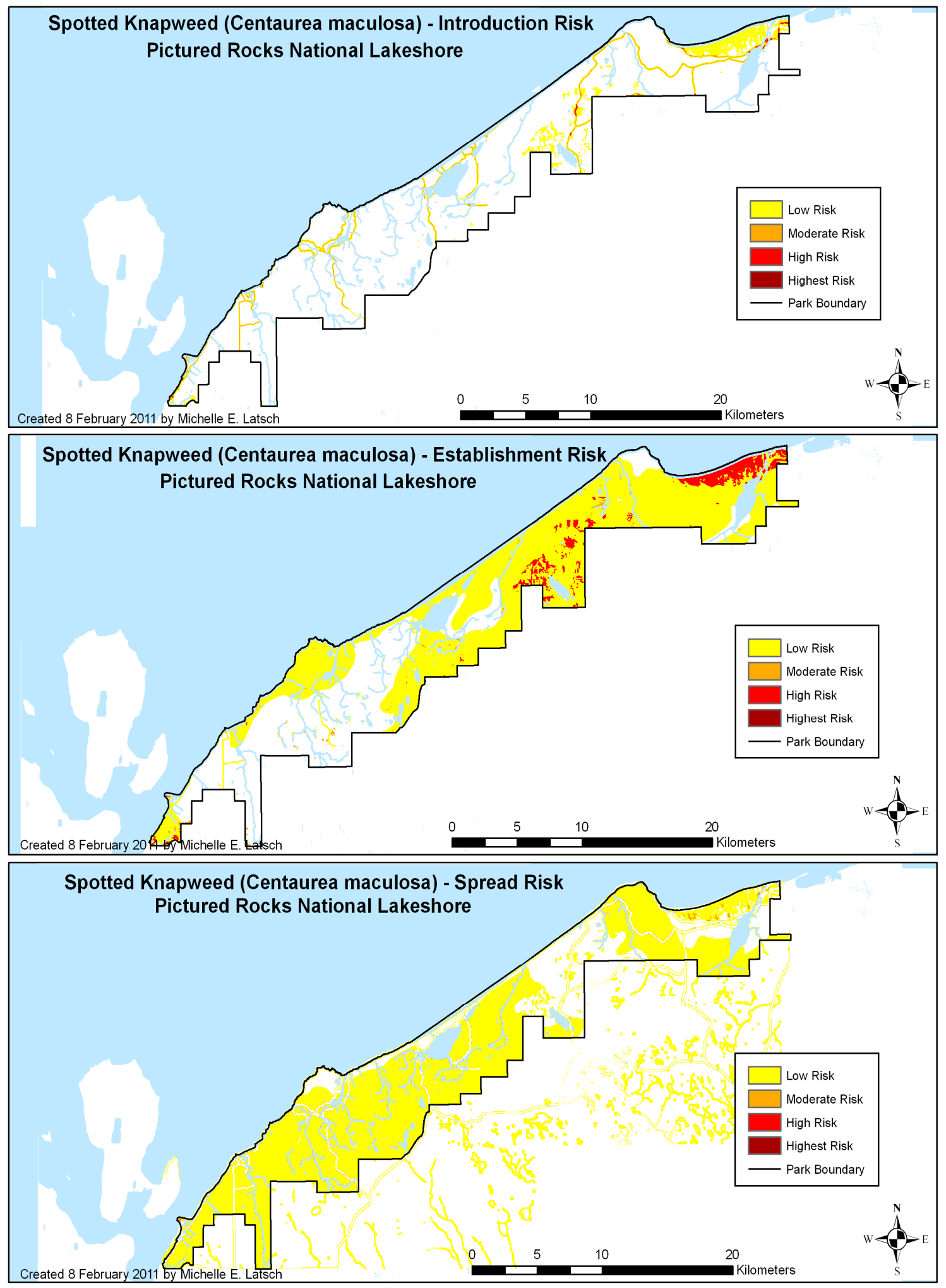

Figure 3.29. Output map for introduction, establishment, and spread of spotted knapweed. 

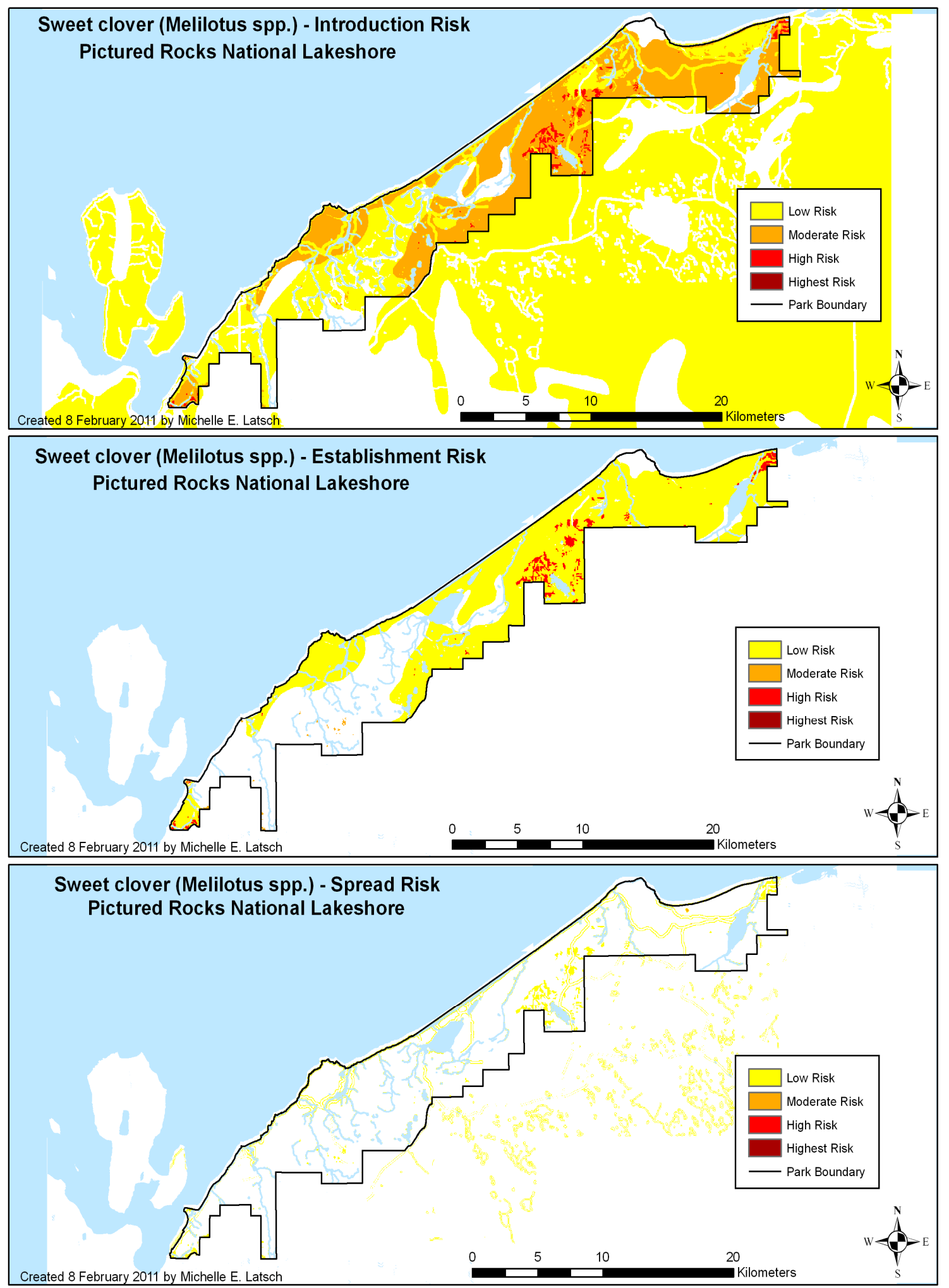

Figure 3.30. Output map for introduction, establishment, and spread of sweet clover. 


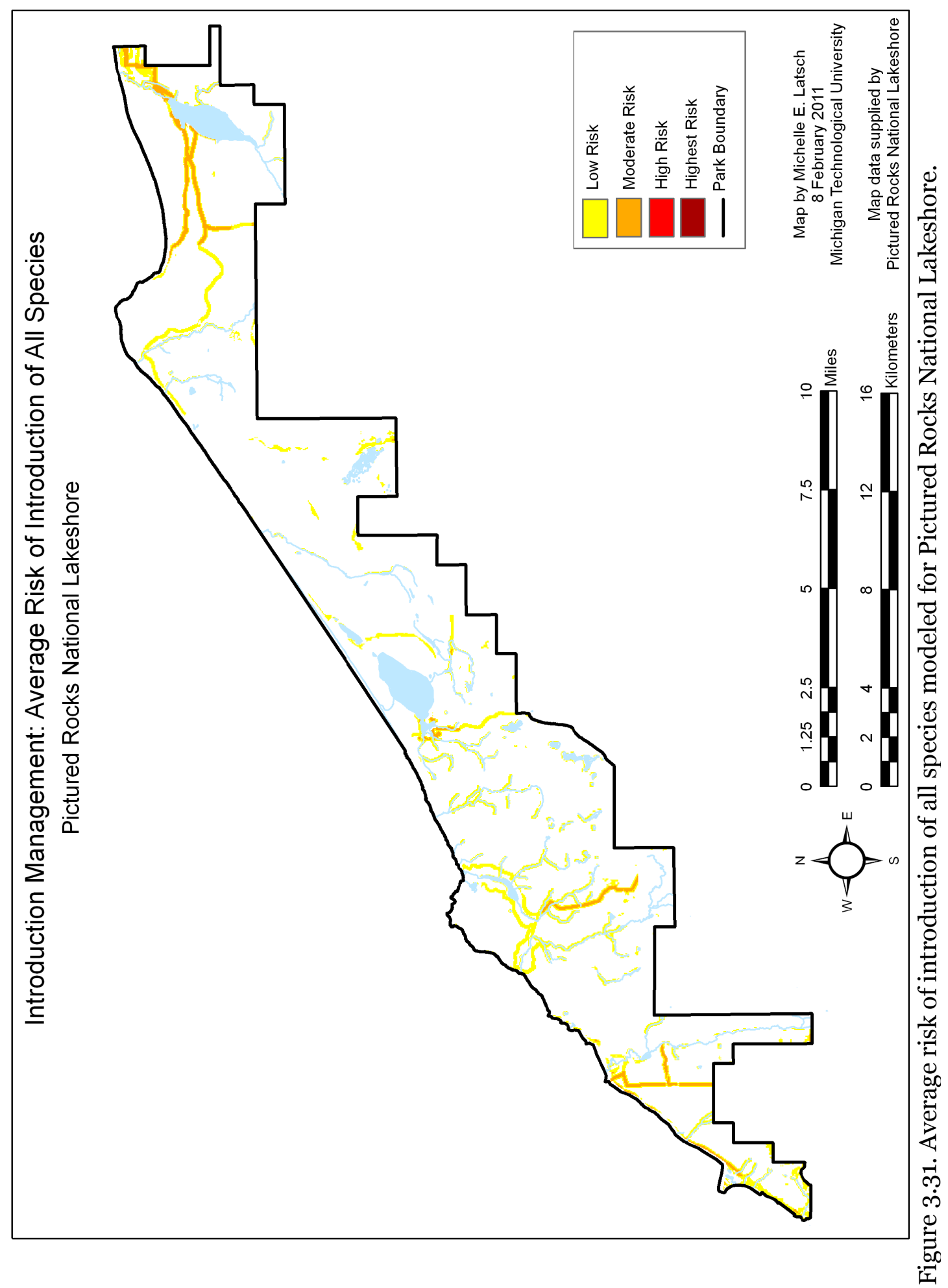




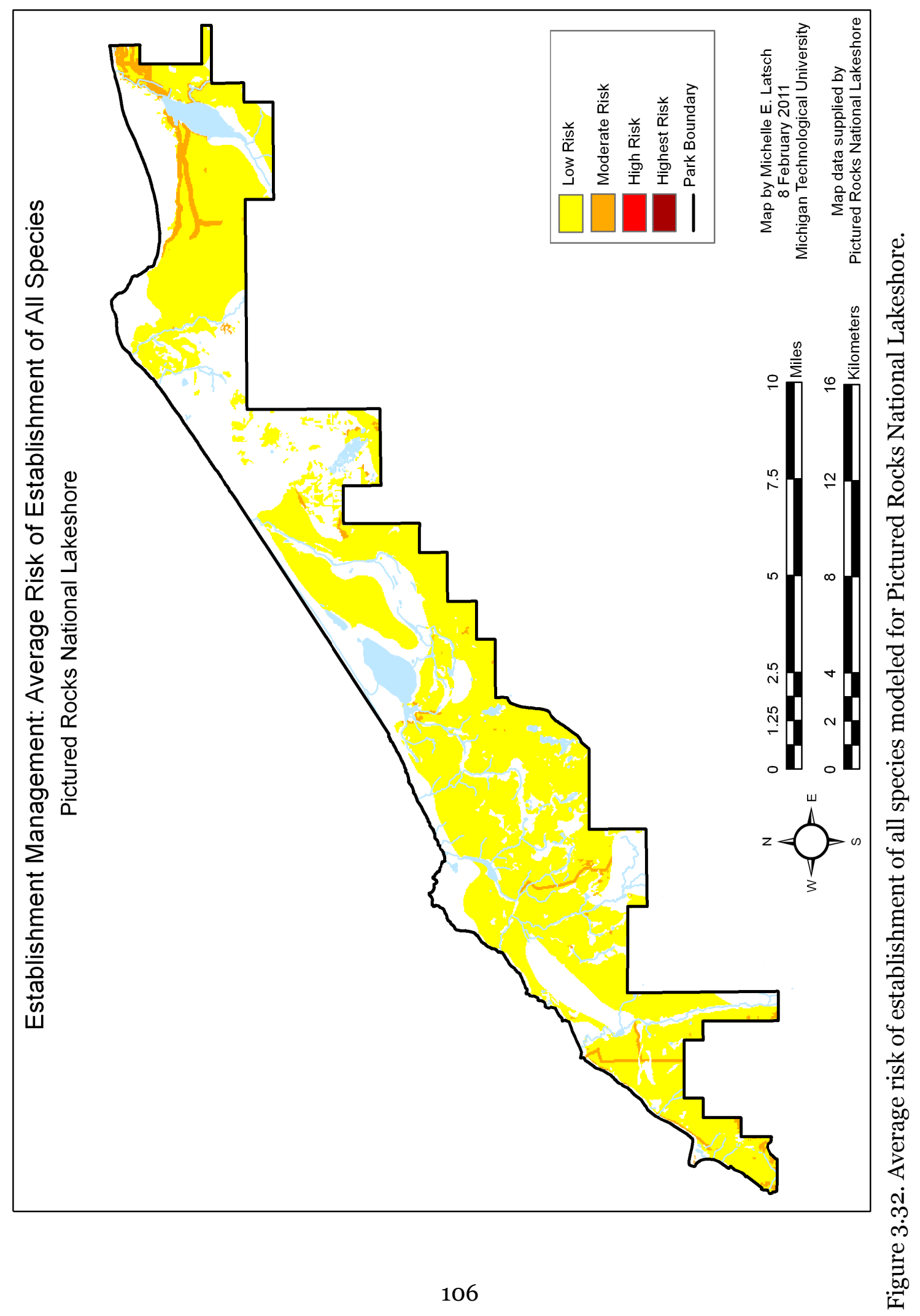




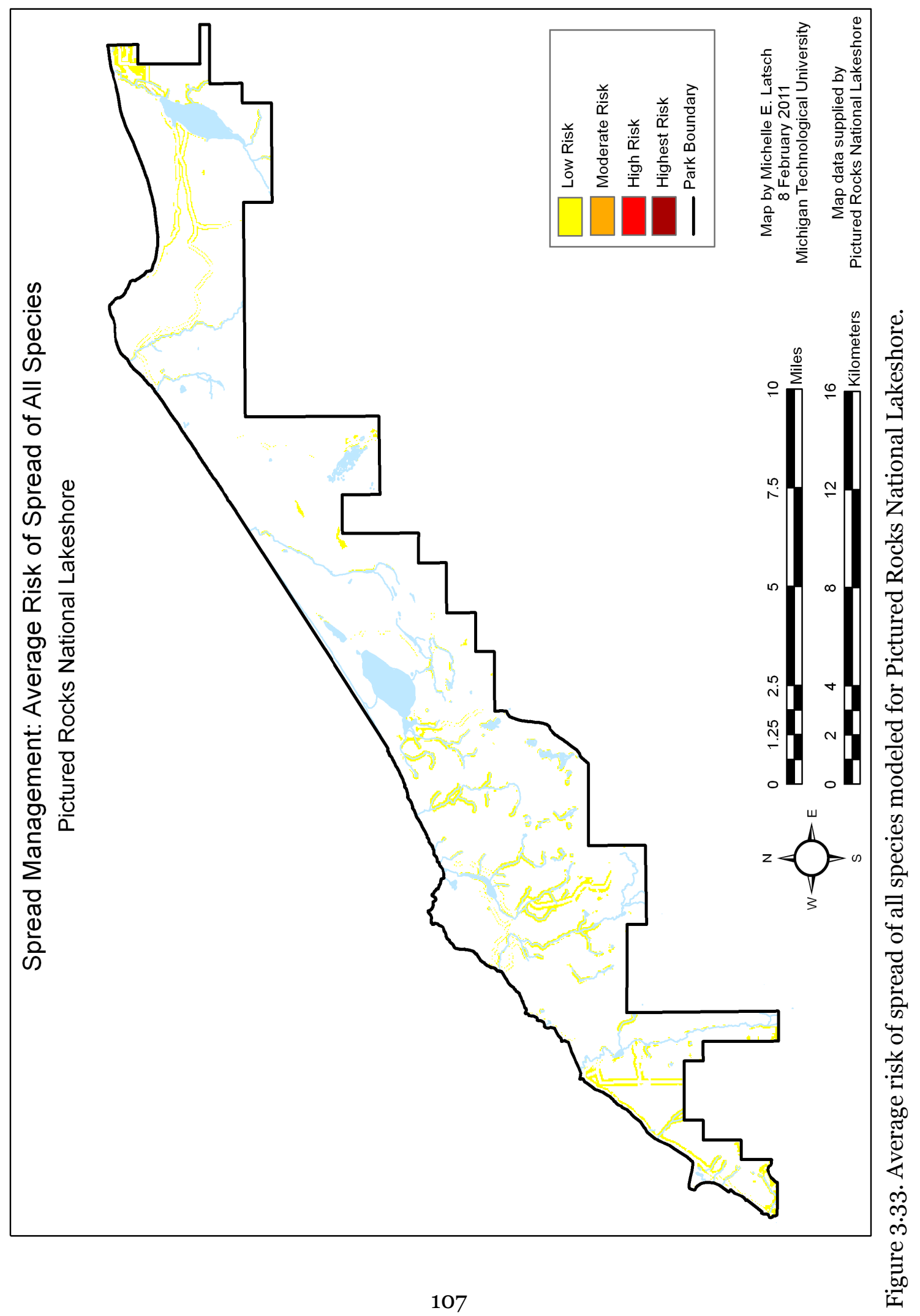




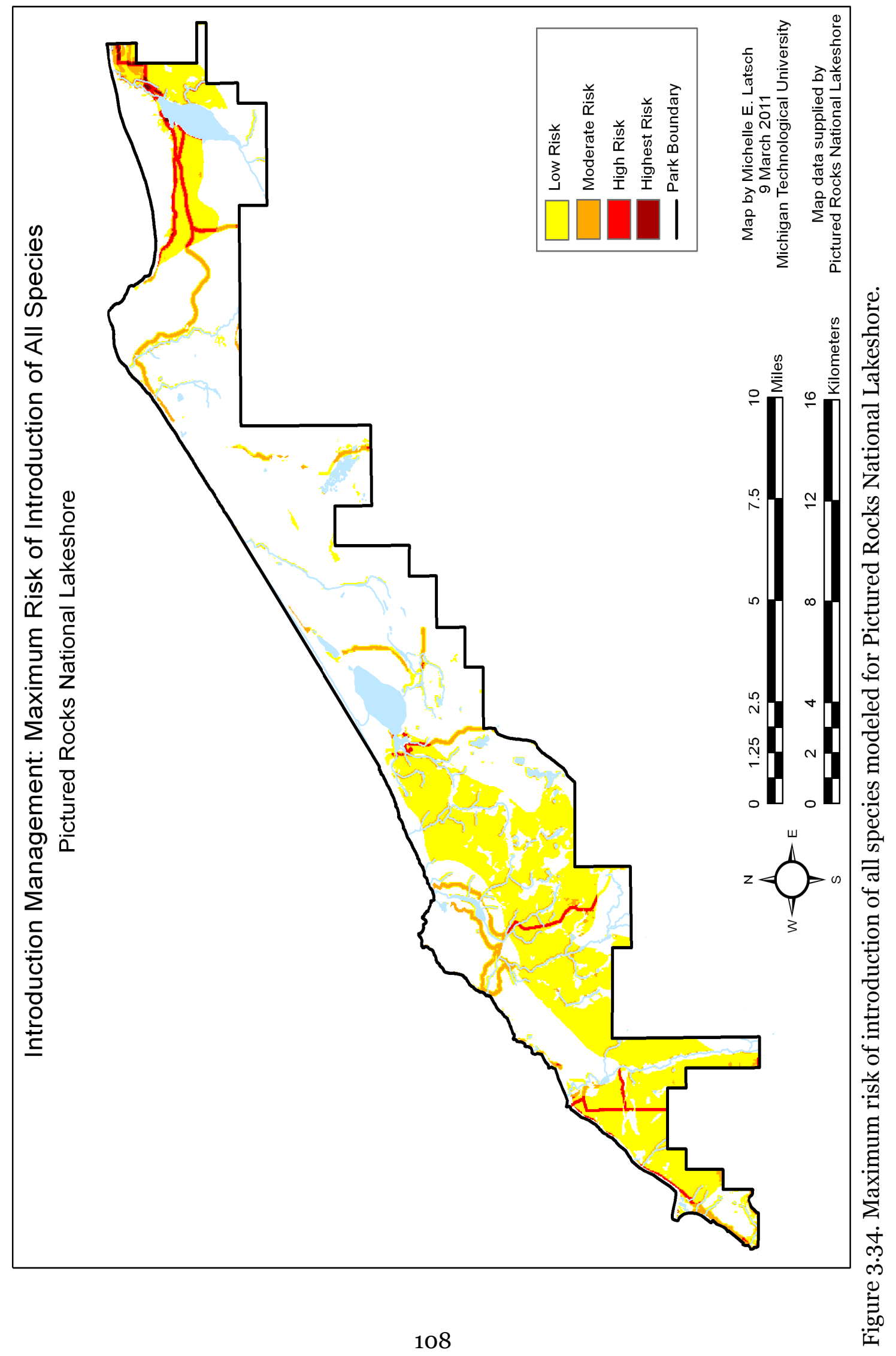




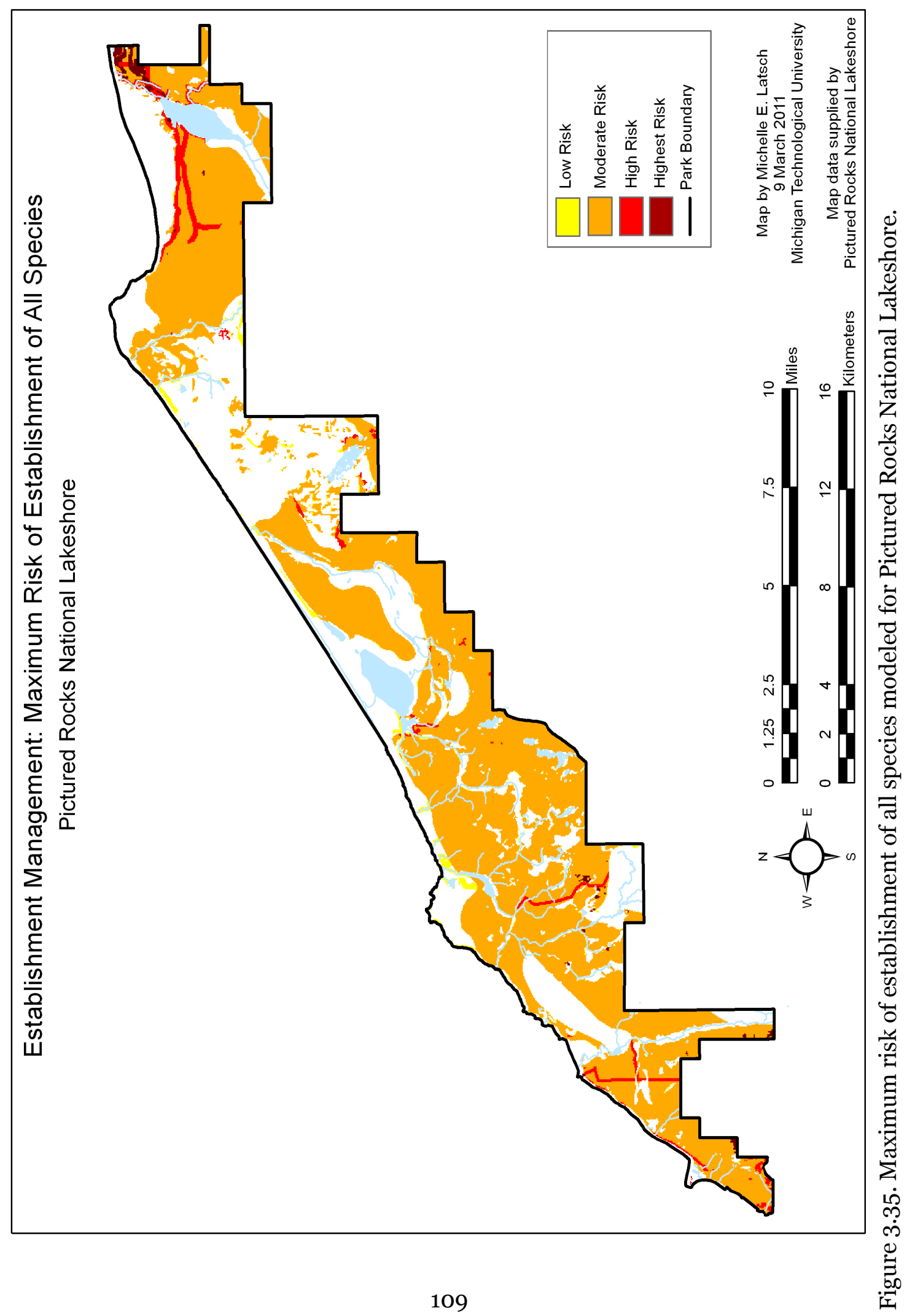




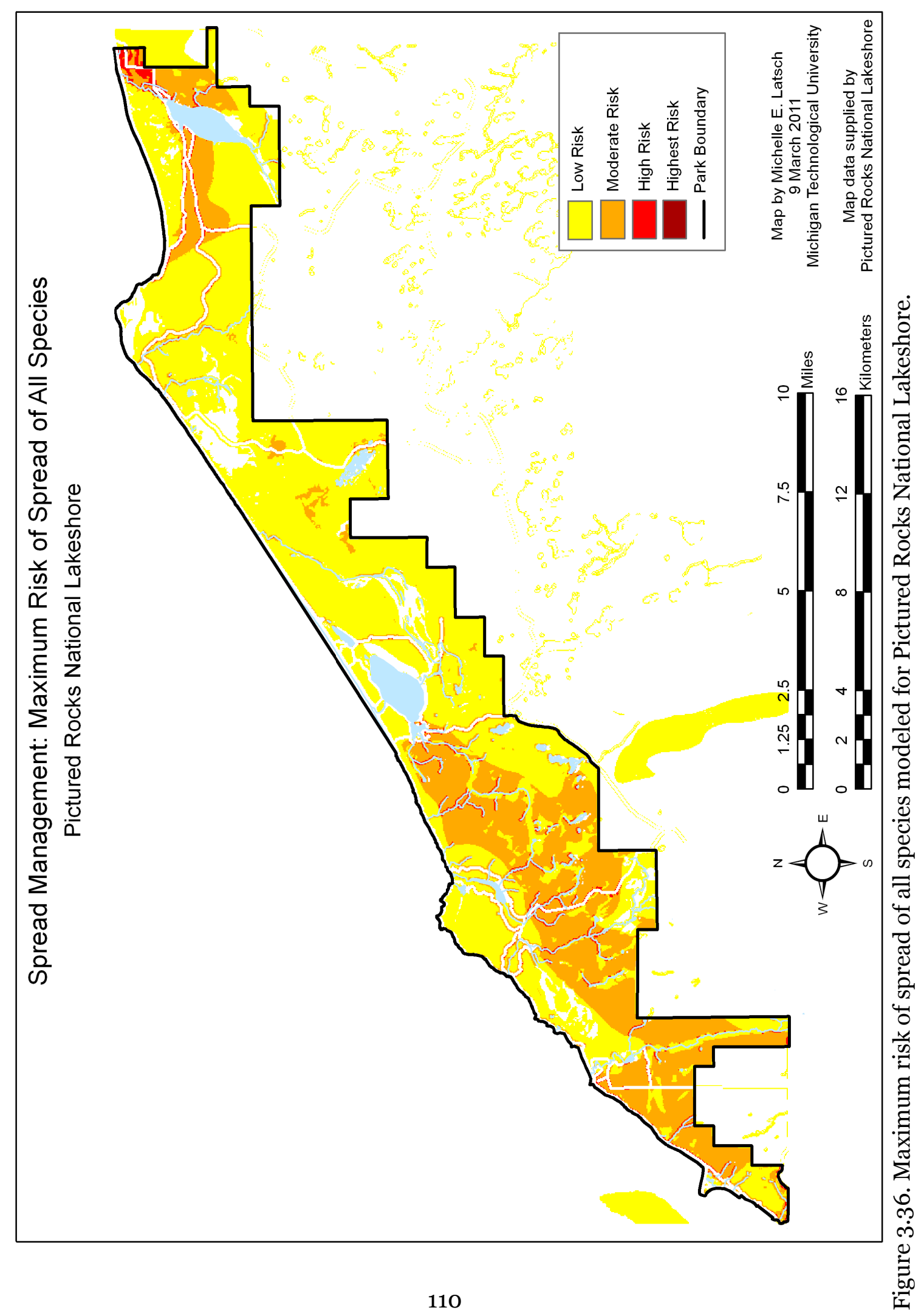




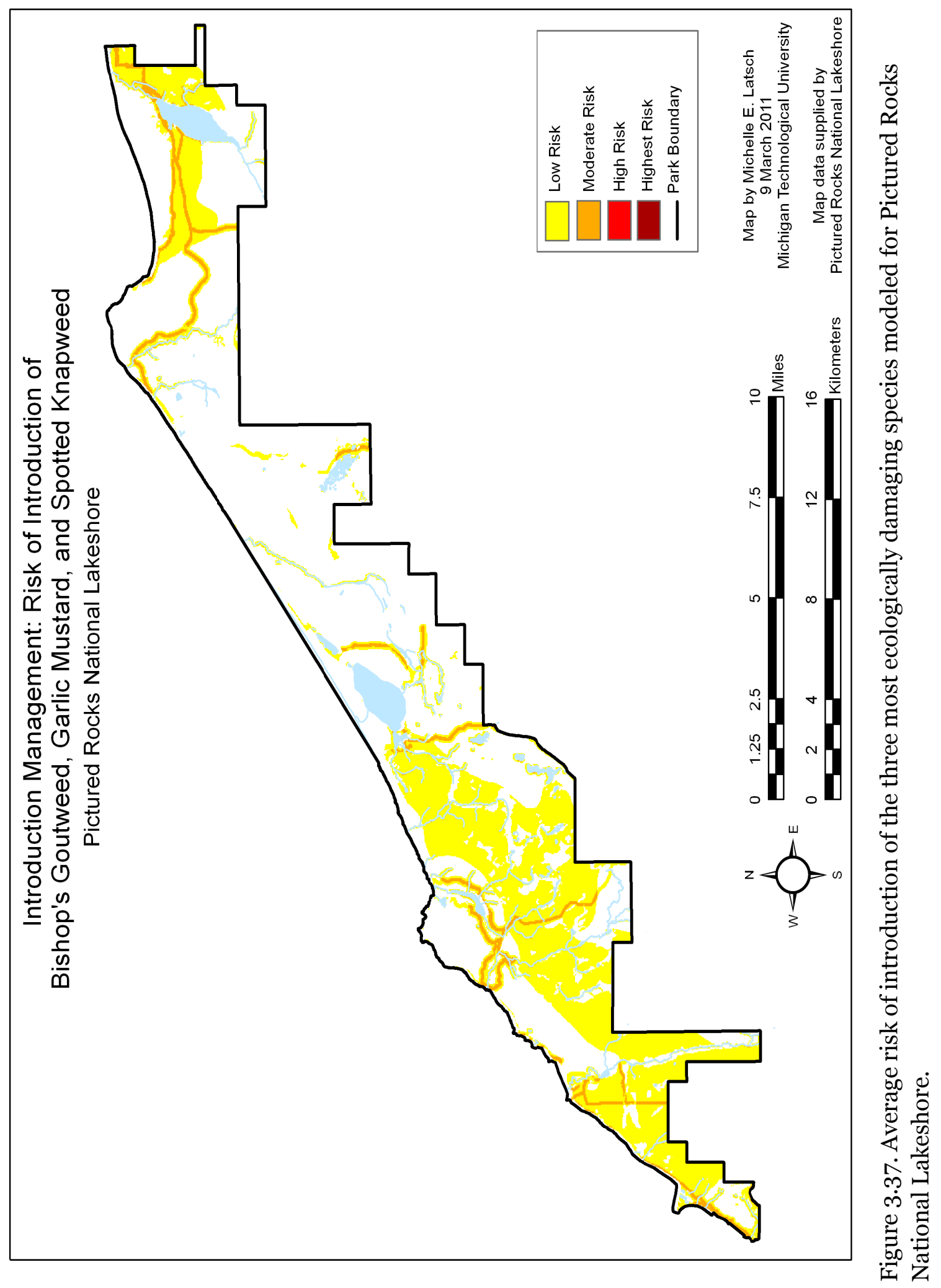




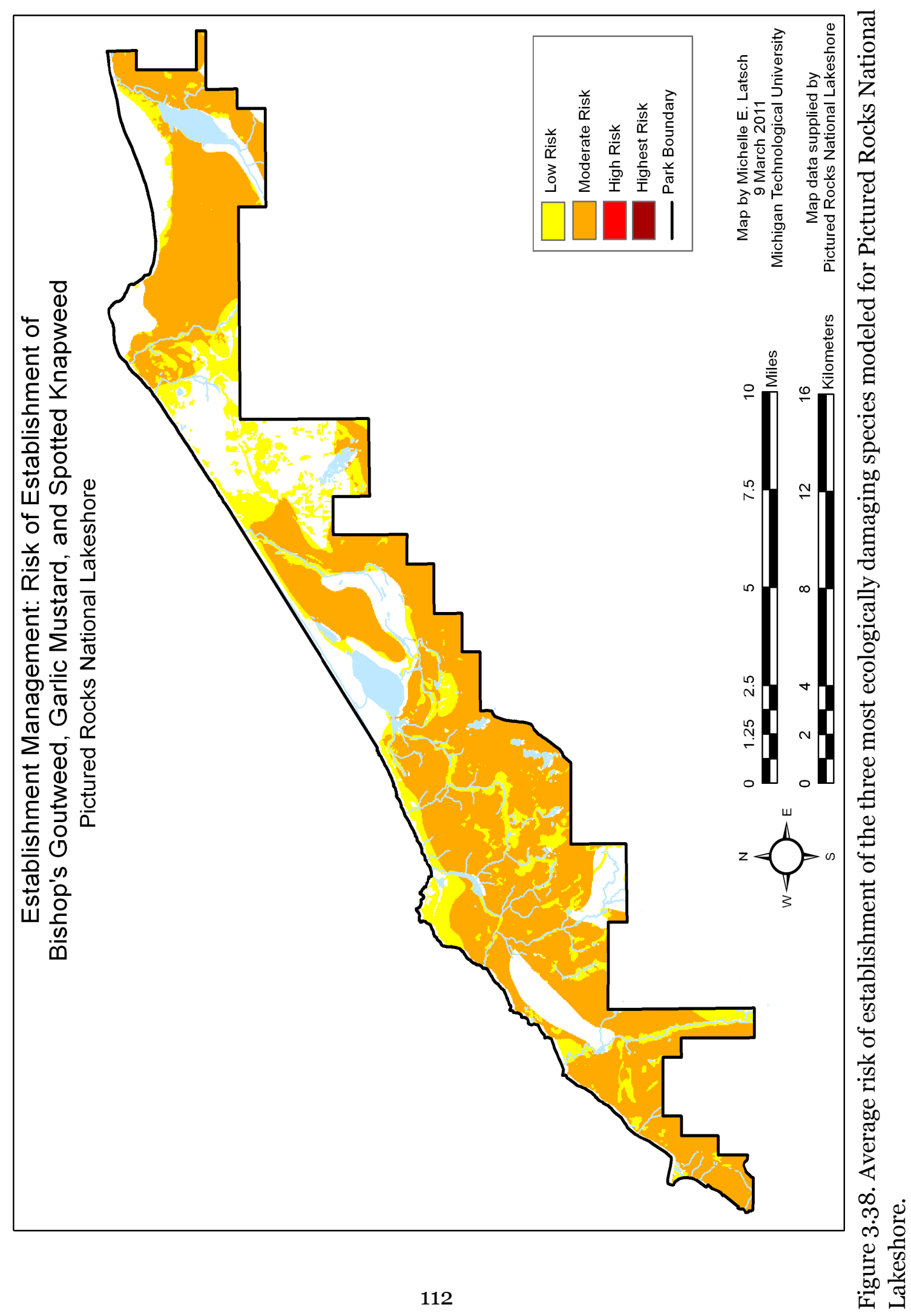




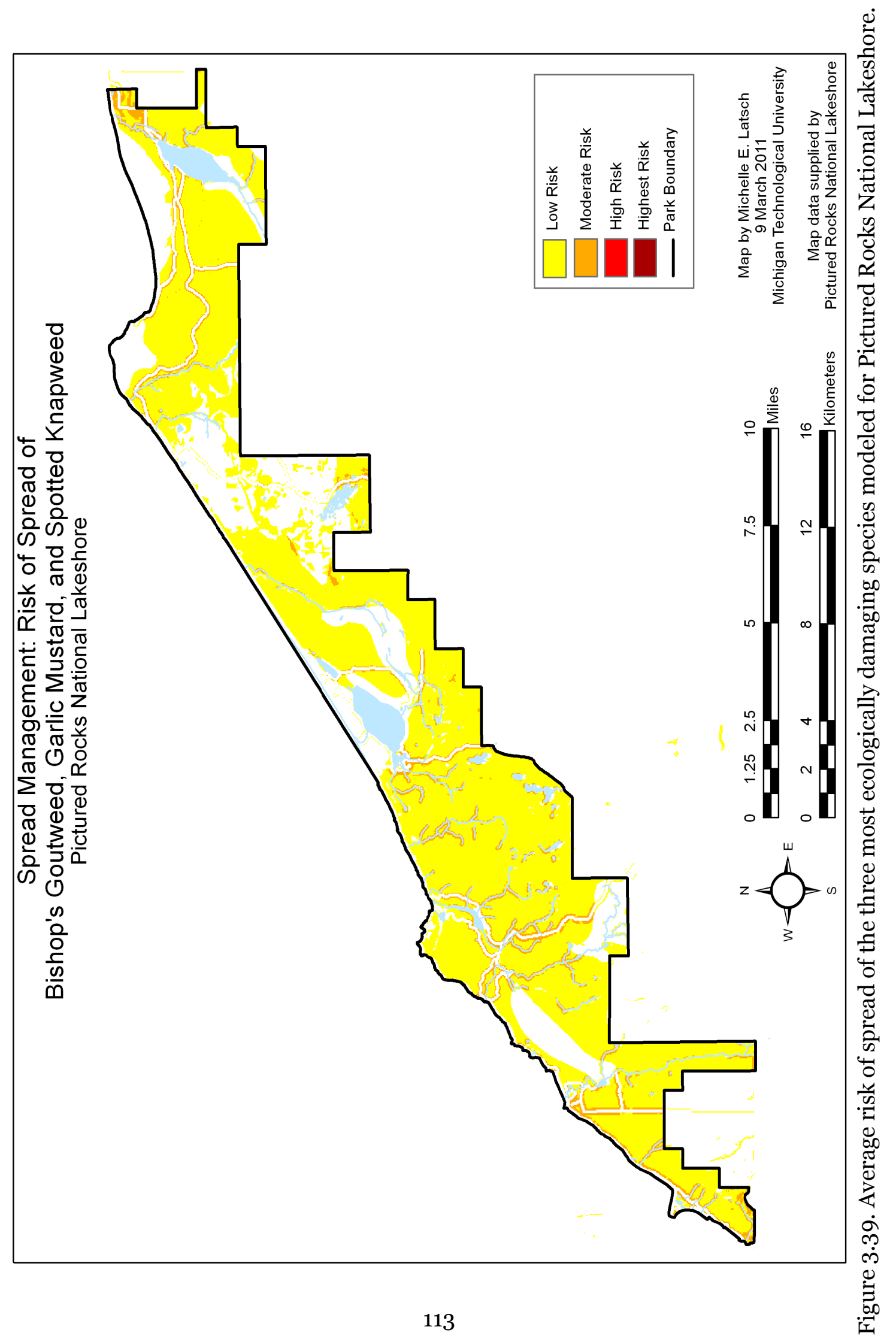




\title{
CHAPTER 4
}

\section{PLANT COMMUNITY COMPOSITION}

IN ACTIVE DUNE AREAS INVADED

BY SPOTTED KNAPWEED (Centaurea maculosa Lam.)

AT PICTURED ROCKS NATIONAL LAKESHORE

IN ALGER COUNTY, MICHIGAN

\begin{abstract}
The Grand Sable Dunes of Pictured Rocks National Lakeshore in the Upper Peninsula of Michigan are an open dune ecosystem. The dunes are a protected area but are susceptible to the introduction of invasive plants. The invasive spotted knapweed (Centaurea maculosa Lam.) has invaded more than 120 hectares of the Grand Sable Dunes. This study assessed areas with zero, low, and high abundances of spotted knapweed for species richness, diversity, evenness, and species composition. Species richness and diversity increased as spotted knapweed abundance increased, while species evenness varied with abundance. The native graminoids increased in abundance while the native plants Lake Huron tansy, starry false Solomon's seal, beach pea, dune cherry, wild sage, and smooth rose decreased as the abundance of spotted knapweed increased. The non-dune plant horsetail decreased as spotted knapweed abundance increased, as did the non-native hawkweed and red sorrel. Differences in percent cover and number of individuals of these species, as well as in richness, diversity, and evenness may have been due to dune stabilization through natural succession or spotted knapweed invasion. Controlling the spreading population of spotted knapweed in the Grand Sable Dunes could maintain native plant populations.
\end{abstract}




\section{Introduction}

Pictured Rocks National Lakeshore was designated a protected area by Congress in 1966 to preserve unique shoreline features of Lake Superior. The park boundaries not only protect unique geographic features such as sandstone cliffs and active lacustrine dunes, but also many unique plant habitat types (National Park Conservation Association 2007). Fifteen threatened or endangered species in the state of Michigan are found at Pictured Rocks National Lakeshore, as are 12 state species of concern (Michigan Department of Natural Resources and Environment 2009).

The Grand Sable Dunes of Pictured Rocks National Lakeshore comprise approximately 950 hectares along the south shore of Lake Superior. Approximately 740 hectares of the Grand Sable Dunes is reserved as a Research Natural Area. This area is designated for research into preserving the unique active dune ecosystem, and permanent research sites can be established there that will generally be undisturbed (Pictured Rocks National Lakeshore 2007). The dunes of Pictured Rocks National Lakeshore are a unique ecosystem along the shore of Lake Superior. They are the only active lacustrine sand dunes on Lake Superior, and are the only location that Pitcher's thistle (Cirsium pitcher Torr. Ex Eaton) is found in some abundance on Lake Superior (Leutscher personal communication 2008).

Active sand dunes are considered such due to shifting sand, which continually change the ecosystem. Native dune plant communities have adapted to this environment through wind dispersal of seed as well as germination requirements that do not need much organic matter or water. The resulting open, sparse plant communities are strongly affected by shifting sands. The species that establish on the dunes depend on the restraints imposed by seed dispersal and predation and weather conditions rather than previously dominant species (Lichter 2000). Stabilization of the dunes will change the 
plant population dynamics of the dunes (Strahler and Strahler 1978). As the movement of sand is suppressed over time, stabilization occurs and provides opportunities for plants that will establish in dry, sandy soil but are not adapted for sand burial (Strahler and Strahler 1978).

Active lacustrine dunes are in a continual state of primary succession, where plant communities establish on newly formed substrate (Radosevich et al. 2007). There is no single climax community and the vegetation communities seem to exist in a state of non-equilibrium in the dynamic environment of the dunes (Olson 1958). Succession occurs at a more rapid rate than in many other ecosystems, as a series of strong windstorms can cause large substrate shifts if the area is sparsely vegetated. Sand migration can cause large buildups if the area is repeatedly stabilized by plants and then reburied (Bach 1978).

Different plant communities develop following disturbances and in the area of the Grand Sable Dunes most frequented by human visitors, which creates opportunity for introduction of invasive plants. After a major disturbance, species with mechanisms for broad dispersal, rapid growth rates, and short life spans usually arrive first (Radosevich et al. 2007). As vegetation populates the dunes, the effects of wind and wind velocity decrease (Bach 1978), which creates more suitable habitat for late-successional species. The degree to which sand is moved and the type of sand movement seem to be the primary determinants of plant populations and distributions.

The largest threat to the dune habitats of Pictured Rocks National Lakeshore is recreation. Over the past 50 years, aerial photos show an increase in open sand in hightraffic areas (National Park Conservation Association2007). Those same aerial photos show an increase in the size of the encroaching jack pine forests. Invasive plant species 
are also a constant threat to dune habitats due to the displacement of native and rare plants.

Spotted knapweed (Cenaturea maculosa Lam.) is one of the most widely distributed invasive plants in North America in a variety of habitats (Carpinelli 2003), and is one of the invasive plants that Pictured Rocks National Lakeshore is most concerned about. Spotted knapweed was introduced to North America from Europe in the early twentieth century as a contaminant in crop seed (United States Department of Agriculture 2011). Not only can a single spotted knapweed plant produce more than 1,000 seeds per season, but those seeds are viable for more than five years (United States Department of Agriculture 2011), which often results in a re-infestation after eradication or other control attempts. Spotted knapweed has few natural enemies and biological control releases have failed to control the population in other areas (Lym and Zollinger 1992). Simple single-year herbicide applications have proven unsuccessful in decreasing spotted knapweed density, biomass, or dominance (MacDonald et al.2007). The plant also releases allelopathic compounds into the soil so that competing native plants have less chance of reestablishing themselves (Fletcher and Renney 1963).

Spotted knapweed is well adapted to invade the dry, open, and disturbed habitat of the Grand Sable Dunes. In doing so, the plant has the potential to stabilize the dunes to create optimal conditions for it and other non-dune plants. The quickly growing, farreaching roots could create a lattice through the top layers of sand and eventually cause large buildups of dune stabilizing root systems if repeatedly buried. Spotted knapweed could also expedite the stabilization process in the dunes, which in turn creates a new niche for different plant species. Other studies in non-dune habitats have found that species diversity tends to decrease as invasive plants spread (Meiners and Cadenasso 
2005). In an area that contains many rare and endangered species, this is an ongoing and serious problem.

Previous studies in the Grand Sable Dunes have concluded that areas without spotted knapweed populations had higher dune plant diversity than invaded areas (Marshall et al. 2008). Exotic plant diversity was shown to be lower in areas from which spotted knapweed was absent (Marshall et al. 2008). This same study also found an increased abundance of insects from the Formicidae family in the general area of the study, providing evidence that the study area has been stabilized at a rapid rate (Marshall et al. 2008). Losses of native plant diversity may be attributable to the spotted knapweed invasion and the associated facilitation of other invasive plants (Myers and Bazely 2003).

Shifts in community composition and structure in response to invasion by spotted knapweed may be dramatic (Ortega and Pearson 2005). Increases in species diversity are expected as dunes are stabilized; however, the dune plant community will plateau and decrease over time (Morrison and Yarranton 1973). Invasive plants tend to dominate native species and spotted knapweed in particular has been shown to have a negative correlation with native plant diversity (Kedzie-Webb et al. 2001; Ortega and Pearson 2005; Maron 2008).

This study evaluated the differences in vegetation in areas colonized by the exotic invasive spotted knapweed in the Grand Sable Dunes of Pictured Rocks National Lakeshore in the Upper Peninsula of Michigan. The study site was an area of active lacustrine dunes invaded with spotted knapweed near the northeastern end of Grand Sable Lake. Pitcher's thistle, a federally endangered plant, is common in the Grand Sable Dunes, and Lake Huron tansy (Tanacetum huronense Nutt.), a species threatened in the 
state of Michigan, are also common in the dunes in the study area. Characteristic dune species were present throughout the study area, as were native and non-native plants that are not considered dune species.

No data exist for dune plant dynamics in response to invasion by spotted knapweed for Pictured Rocks National Lakeshore, although several studies have been implemented in the dunes to assess community composition. This study was designed to evaluate the community composition in an invaded area of the dunes and create longterm sampling plots to provide methods for monitoring plant dynamics. Specifically, the objective of the study was to assess the effect of spotted knapweed on native and exotic plant dynamics.

\section{Methods}

The study site was located in the Grand Sable Dunes of Pictured Rocks National Lakeshore in the Upper Peninsula of Michigan (Figure 4.1). The area of invasion was identified as the area of the dunes most extensively invaded by spotted knapweed. The general area of invasion was delineated in 2008 (Figure 4.2) by traversing the perimeter of the invaded area on foot and mapping using a GPS unit. The study plots were established within the invaded area.

\section{Field Methods}

Nine plots, 33 meters by 19 meters and each containing 15 subplots, were established in the Grand Sable Dunes (Figure 4.3) in June 2008. Three plots were established in areas with no spotted knapweed, three plots were set in areas with low percent cover of spotted knapweed (below 35\% cover), and three plots were set in areas with high percent cover of spotted knapweed present (above 35\% cover). The four 
corners of each of the 9 plots were marked with rebar and tags were attached to identify the plot locations.

Within each plot, a 3 by 5 grid of 5 meter by 5 meter subplots was established. Subplots were separated by 2 meter buffers (Figure 4.4). Within each subplot, five 1 meter by 1 meter quadrats of vegetation ( $n=225$ quadrats for each level of spotted knapweed) were sampled. The quadrat used was constructed of PVC pipe. Percent cover and number of individuals for each plant species or group were recorded based on ocular measurements. Percent cover was recorded in $5 \%$ cover classes by any species with less than $5 \%$ cover recorded as $1 \%$. Any species rooted within the quadrat was recorded as an individual. Any part of a plant occurring inside the quadrat was included in the percent cover measurement. A total of 30 species were quantified during the course of this study (Table 4.1).

\section{Statistical Methods}

Species richness, Shannon-Wiener diversity, and species evenness were calculated for each subplot. Mean percent cover and mean number of individuals per species were calculated for each species or species group. Species richness represents the

number of species present within each subplot. Shannon-Wiener diversity was calculated using the equation:

$$
\mathrm{H}=-\sum p_{i} \ln p_{i} \quad \text { (Equation 4.1) }
$$

Where $p_{i}=$ percent cover per species or the number of individuals per species (Hayek and Buzas 1997). Species evenness was calculated with the equation:

$$
\mathrm{E}=\mathrm{H} / \ln (\mathrm{S}) \quad(\text { Equation 4.2) }
$$

Where H = Shannon-Wiener diversity and S = species richness (Hayek and Buzas 1997). 
An arcsine transformation was used for percent cover data. A log transformation was used for the number of graminoids data due to some of the subplots having very high graminoid numbers which resulted in the presence of an exponential relationship between the means and variances for these data. A square root transformation was used for the number of individuals of other species due to the high occurrence of zeros in the dataset that resulted in the presence of a linear relationship between the means and variances for these data. The data transformations enabled the assumption of homogeneity of variance to be met for subsequent analysis.

All analyses were performed using Statistix 8 (Statistix 2003). Split-plot ANOVA was used to test differences in percent cover and number of individuals of each species and the richness, diversity, and evenness summary data among the three spotted knapweed densities (treatments) (Statistix 2003). The main plot factor in the analysis was the plot number, and the subplot factor was the number of the subplot. Two userdefined contrasts were performed after each ANOVA. The first contrast compared areas without spotted knapweed present with areas in which spotted knapweed is present (low and high percent cover combined). The second contrast tested areas with low percent cover of spotted knapweed versus areas with high percent cover of spotted knapweed.

Linear regression was used to examine the relationships between the percent cover of spotted knapweed and the percent cover of each of the other species. Linear regression was also used to examine the relationships between the number of individuals of spotted knapweed and the number of individuals for each of the other species.

\section{Results}

\section{Species Composition}

Percent cover of dune species was highest in areas without spotted knapweed 
( $\mathrm{p}<0.001)$, and lowest in areas with high densities of spotted knapweed $(\mathrm{p}<0.001)$

(Figure 4.5). When spotted knapweed was excluded from the analysis, dune species compose a higher percentage of the plant population than the non-dune species, although none of the comparisons were significant (Figure 4.6). The same trends were observed in the number of individuals data (Figures 4.7 and 4.8). Percent cover of nondune species was greater in areas invaded by spotted knapweed compared to areas not invaded $(\mathrm{F}=6.98, \mathrm{df}=1,134, \mathrm{p}<0.001)$ (Table 4.2). Percent cover of non-dune species was greater in areas with high spotted knapweed abundance compared to areas with low spotted knapweed abundance $(\mathrm{F}=23.55, \mathrm{df}=1,134, \mathrm{p}<0.001)$ (Table 4.2). Number of individual non-dune species was greater in areas with high spotted knapweed abundance compared to areas with low spotted knapweed abundance $(\mathrm{F}=6.12, \mathrm{df}=1,134, \mathrm{p}<0.032)$ (Table 4.2). The percent cover of dune species between areas where spotted knapweed was present or absent did not differ.

Species Richness, Diversity, and Evenness

Species richness was lowest in areas with no spotted knapweed $(\mathrm{p}<0.001)$ (Figure 4.9). Species diversity was lowest in areas with no spotted knapweed $(\mathrm{p}<0.001)$ and highest in areas with high abundances of spotted knapweed $(\mathrm{p}<0.001)$ in terms of both percent cover and number of individuals (Figures 4.10 and 4.11). Evenness in terms of percent cover was lowest in areas with low spotted knapweed abundance and highest in areas of high spotted knapweed abundance $(\mathrm{p}<0.001)$ (Figure 4.12). In terms of number of individuals, evenness was highest in areas without spotted knapweed present $(\mathrm{p}<0.001)$ (Figure 4.13). 
Richness: Species richness was greater in areas with spotted knapweed present compared to areas without spotted knapweed present $(\mathrm{F}=33.45, \mathrm{df}=1,134, \mathrm{p}<0.001)$ (Table 4.3).

Diversity: Species diversity in terms of percent cover $(\mathrm{F}=29.15, \mathrm{df}=1,134$, $\mathrm{p}<0.001)$ and number of individuals $(\mathrm{F}=18.45, \mathrm{df}=1,134, \mathrm{p}<0.001)$ was lowest in areas without spotted knapweed populations (Tables 4.3 and 4.4). Species diversity was highest in areas of high spotted knapweed abundance for both percent cover $(\mathrm{F}=5.3$, $\mathrm{df}=1,134, \mathrm{p}<0.001)$ and number of individuals $(\mathrm{F}=6.7, \mathrm{df}=1,134, \mathrm{p}<0.001)($ Tables 4.3 and 4.4).

Evenness: Species evenness of percent cover was greatest in areas of high spotted knapweed abundance $(\mathrm{F}=14.16, \mathrm{df}=1,134, \mathrm{p}<0.001)$ (Table 4.3). Species evenness of number of individuals was greatest in areas without spotted knapweed populations $(\mathrm{F}=5.3, \mathrm{df}=1,134, \mathrm{p}=0.011)($ Table 4.4) .

Species Comparisons

Percent cover of native dune plants: Eleven of the total thirty species quantified were identified as dune species. The three most populous dune plants (graminoids, Lake Huron tansy, and starry false Solomon's seal) were highest in areas with an absence of spotted knapweed (Table 4.5). Graminoid percent cover was approximately 60\% in areas without spotted knapweed, while percent cover was approximately $40 \%$ in areas with low abundance of spotted knapweed and approximately $25 \%$ in areas with a high abundance of spotted knapweed (Table 4.5). Lake Huron tansy occurred only in areas where spotted knapweed was not present. Beach pea and wild sage populations were highest in areas with low spotted knapweed abundance, while dune cherry, hairy puccoon, wild rose, and wild strawberry were most populous in areas highly invaded by spotted knapweed. 
Percent cover of the native dune graminoids was greatest in areas without spotted knapweed $(\mathrm{F}=39.73, \mathrm{df}=1,134, \mathrm{p}<0.001)$ and lowest in areas of high spotted knapweed abundance $(\mathrm{F}=11.22, \mathrm{df}=1,134, \mathrm{p}<0.001)$ (Table 4.5). Percent cover of starry false Solomon's seal was greatest in areas without spotted knapweed $(\mathrm{F}=9.56, \mathrm{df}=1,134$, p<0.001), and Lake Huron tansy occurred only in areas in which spotted knapweed had not invaded $(\mathrm{F}=82.58, \mathrm{df}=1,134, \mathrm{p}<0.001)$ (Table 4.5). Percent covers of beach pea $(\mathrm{F}=7.9, \mathrm{df}=1,134, \mathrm{p}=0.002)$ and smooth $\operatorname{rose}(\mathrm{F}=9.5, \mathrm{df}=1,134, \mathrm{p}<0.001)$ were lowest in areas with high spotted knapweed abundance (Table 4.5). Percent cover of wild sage was greatest in areas with low spotted knapweed abundance $(\mathrm{F}=3.83, \mathrm{df}=1,134, \mathrm{p}=0.034)$ and least in areas with high spotted knapweed abundance $(\mathrm{F}=17.68, \mathrm{df}=1,134, \mathrm{p}<0.001)$ (Table 4.5). Percent cover of dune cherry was highest in areas with a high abundance of spotted knapweed $(\mathrm{F}=10.77, \mathrm{df}=1,134, \mathrm{p}<0.001)$ and lowest in areas without spotted knapweed () $\mathrm{F}=4.31, \mathrm{df}=1,134, \mathrm{p}=0.023)($ Table 4.5).

Percent cover of non-dune plants: The remaining nineteen species were identified as non-dune species. Species that could not be identified as a dune species although can be found on dry, sandy sites were included in this grouping. The three most common non-dune species were spotted knapweed, hawkweed, and red sorrel. These species were also considered by the park to be invasive or nuisance species. These three species were also most populous in areas with high levels of spotted knapweed and least populous in areas with an absence of spotted knapweed. Poison ivy, white campion, and yarrow are non-dune species that were also most populous in areas with no spotted knapweed. Goldenrod, red clover, lyre-leaved rockcress, and white clover were most common in areas with low abundance of spotted knapweed. Bearberry, horsetail, and lily-of-the-valley were most common in areas in which spotted knapweed was absent. 
Percent cover of spotted knapweed was greatest in areas with high spotted knapweed abundance $(\mathrm{F}=68.95, \mathrm{df}=1,134, \mathrm{p}<0.001)$ and least in areas without spotted knapweed ( $F=95.17, d f=1,134, p<0.001)$ (Table 4.5). Percent cover of hawkweed was also greatest in areas with high spotted knapweed abundance $(\mathrm{F}=5.93, \mathrm{df}=1,134$, $\mathrm{p}=0.007$ and lowest in areas without spotted knapweed $(\mathrm{F}=38.05, \mathrm{df}=1,134, \mathrm{p}<0.001)$ (Table 4.5). Red sorrel followed the same trend ( $\mathrm{F}=6.01, \mathrm{df}=1,134, \mathrm{p}=0.007 ; \mathrm{F}=30.37$, $\mathrm{df}=1,134, \mathrm{p}<0.001)$. Horsetail was significantly greater in areas without spotted knapweed present $(\mathrm{F}=8.48, \mathrm{df}=1,134, \mathrm{p}<0.002)$.

Number of individuals of dune species: The data for the number of individuals of dune species showed the same general trends as percent cover, although less pronounced. Dune species were most common in areas in which spotted knapweed was absent. Beach pea and wild sage populations were highest in areas with low spotted knapweed abundance. Dune cherry, hairy puccoon, wild rose, and wild strawberry were most populous in areas highly invaded by spotted knapweed.

The number of individuals of graminoids was greatest in areas without spotted knapweed $(\mathrm{F}=4.36, \mathrm{df}=1,134, \mathrm{p}=0.023)$ and least in areas with high abundance of spotted knapweed $(\mathrm{F}=5.15, \mathrm{df}=1,134, \mathrm{p}=0.013)$ (Table 4.6). Lake Huron tansy was only found in areas without spotted knapweed $(\mathrm{F}=72.36, \mathrm{df}=1,134, \mathrm{p}<0.001)$ (Table 4.6). The number of individual dune cherry was greatest in areas of high spotted knapweed abundance $(\mathrm{F}=9.21, \mathrm{df}=1,134, \mathrm{p}=0.001)$ and lowest in areas without spotted knapweed $(\mathrm{F}=3.79, \mathrm{df}=1,134, \mathrm{p}=0.035)$ (Table 4.6). The number of individuals of wild sage $(\mathrm{F}=13.83, \mathrm{df}=1,134, \mathrm{p}<0.001)$ and beach pea $(\mathrm{F}=5.18, \mathrm{df}=1,134,=<0.012)$ were lowest in areas of high spotted knapweed abundance (Table 4.6). Smooth rose populations were highest in areas of high spotted knapweed abundance $(\mathrm{F}=10.53, \mathrm{df}=1,134, \mathrm{p}<0.001)$, 
while starry false Solomon's seal was greatest in areas without spotted knapweed present $(\mathrm{F}=9.17, \mathrm{df}=1,134, \mathrm{p}<0.001)($ Table 4.6$)$

Number of individuals of non-dune plants: The same general trends for the three most common non-dune plants occurred in the data for the number of individuals as the percent cover data. Those species were spotted knapweed, hawkweed, and red sorrel. There were no populations of those species in areas in which spotted knapweed was absent. The highest populations occurred in areas in which spotted knapweed abundance was high. The same general trends were observed in the remaining number of individual non-dune species as appeared in the percent cover data. Poison ivy and white campion are non-dune species that were also most populous in areas with no spotted knapweed population, but goldenrod also joins this grouping in the number of individual data. Red clover, lyre-leaved rockcress, and white clover were most common in areas with low abundance of spotted knapweed, joined by yarrow when looking at the number of individual. Bearberry, horsetail, and lily-of-the-valley were most common in areas in which spotted knapweed was absent.

The number of individual spotted knapweed plants was greatest in areas of high spotted knapweed abundance $(\mathrm{F}=59.96, \mathrm{df}=1,134, \mathrm{p}<0.001)$ and lowest in areas without spotted knapweed present $(\mathrm{F}=76.09, \mathrm{df}=1,134, \mathrm{p}<0.001)$ (Table 4.6). Hawkweed $(\mathrm{F}=7.36, \mathrm{df}=1,134, \mathrm{p}=0.003)$ and red sorrel $(\mathrm{F}=5.44, \mathrm{df}=1,134, \mathrm{p}=0.010)$ were also greatest in areas with high spotted knapweed abundance and lowest in areas without spotted knapweed $(\mathrm{F}=26.48, \mathrm{df}=1,134, \mathrm{p}<0.001 ; \mathrm{F}=26.24, \mathrm{df}=1,134, \mathrm{p}<0.001)($ Table 4.6). The number of individual horsetail plants were greatest in areas without spotted knapweed present $(\mathrm{F}=9.57, \mathrm{df}=1,134, \mathrm{p}<0.001)$. 


\section{Linear Regression}

Percent cover of each species grouping compared to spotted knapweed

abundance: Percent cover data of dune species showed an inverse relationship with the percent of spotted knapweed $(\mathrm{F}=136.51, \mathrm{df}=1,134, \mathrm{p}<0.001)$ while non-dune species showed a positive relationship to the percent of spotted knapweed $(\mathrm{F}=101.58, \mathrm{df}=1,134$, $\mathrm{p}<0.001$ ) (Figure 4.15)

Number of individuals of each species grouping compared to spotted knapweed abundance: The same trends were shown in the number of individual data (Figure 4.16). The number of individual dune species decreased as the number of spotted knapweed plants increased $(\mathrm{F}=164.89, \mathrm{df}=1,134, \mathrm{p}<0.001)$ while the number of individual nondune species increased as the number of spotted knapweed plant increased $(\mathrm{F}=182.35$, $\mathrm{df}=1,134, \mathrm{p}<0.001)$

\section{Discussion}

The total number of species found in the areas of zero, low, and high abundance of spotted knapweed were 16,14 , and 18 respectively. Based on the number and type of species found by Bach (1978) in his vegetation survey of the dunes, the study area is a slight sand deposition habitat type. It is also possibly transitioning to a stabilized area, based on the extreme species richness Bach found in stabilizing areas. This assessment is further confirmed by the species present in each of those habitat types. The five most common species in areas of slight sand deposition were graminoids, wild sage, hawkweed, dune stitchwort, and goldenrod (Bach 1978). The five most common species in areas of stabilized dunes were hawkweed, wild strawberry, wintergreen, starry false Solomon's seal, and horsetail (Bach 1978). The composition of species in the study area 
compared to Bach's observations coincide, lending more evidence to our theory that this area of the dunes is stabilizing rapidly.

Bach hypothesized that the increased species richness noted in areas of slight sand deposition seemed to be caused by plant invasion from stabilized areas. Species richness in stabilized dune areas was highest and second highest in areas of slight sand deposition. It was also noted at this time that in the depositional habitats, sand burial seems to most restrict plant invasion and growth (Willis 1959; Kumler 1969; Moore 1971; Van der Valk 1974; Bradfield and Orloci 1975; Bach 1978).

Multiple studies have shown the propensity of spotted knapweed to displace native species (Kedzie-Webb et al. 2001; Bais et al. 2003; Weir et al. 2003). Studies also suggest that spotted knapweed invade areas of low species diversity and richness (Kedzie-Webb et al. 2001; Maron and Marler 2007,;Maron and Marler 2008). Yet other studies have shown negative relationships between spotted knapweed abundance and native plant cover (Kedzie-Webb et al. 2001; Ortega and Pearson 2005). This study in Pictured Rocks National Lakeshore observed the same general patterns. The pattern of increasing diversity with increasing spotted knapweed abundance has been observed previously in the park (Marshall et al. 2008). An arthropod study conducted in the study area in 2003 found that ants (Formicidae) are more abundant in areas populated with spotted knapweed (Marshall et al. 2008). This finding strengthens the theory that areas invaded by spotted knapweed have been stabilized at a more rapid rate than would occur through natural dune succession.

\section{Species Composition}

Dune species comprised the largest proportion of percent cover and number of individuals. When spotted knapweed was included in the composition analysis, a trend 
of $90 \%, 65 \%$, and $45 \%$ of dune species is seen in areas with zero, low, and high abundance areas, respectively. When spotted knapweed was excluded from analysis, the trend is much less pronounced, indicating that spotted knapweed has a large impact on percent cover.

Data for the number of individuals showed a more pronounced pattern. Dune species composed most of the species in areas without spotted knapweed present, while non-dune species accounted for the largest number of species in areas of high spotted knapweed density. When spotted knapweed was excluded from the analysis, areas where spotted knapweed is absent have approximately 90\% composition of dune species, low abundance areas are composed of approximately 50\% of dune species, and high spotted knapweed abundance areas are composed of approximately 40\% dune species.

The differences for the contrast between the areas without spotted knapweed versus areas with spotted knapweed for non-dune plant percent cover including spotted knapweed could indicate that spotted knapweed has a significant effect on percent cover. The same is true for the second contrast on non-dune plant number of individuals.

\section{Summary Statistics: Richness, Diversity, and Evenness}

Species richness increased as abundance of spotted knapweed increase (Tables 4.3 and 4.4, Figure 4.9). We suspect that spotted knapweed is a driving force behind this, as it has mechanisms to interrupt natural dune succession (Watson and Renney 1974, Garcia-Mora et al. 2000). Although no baseline data is available to determine if the habitats being invaded have a greater or lower richness than other dune communities, these data suggest that invaded dune areas increase in richness as they are invaded. Spotted knapweed allelopathy may decrease the number of competing species, but seems 
to be unable to keep a multitude of species from invading the highly disturbed dune areas.

Diversity follows the same pattern as richness and increases as the abundance of spotted knapweed increases (Tables 4.3 and 4.4, Figures 4.10 and 4.11). Areas of high spotted knapweed abundance had higher species diversity and yet a lower native dune plant species diversity. Although many studies have stated that invasive plants tend to establish in areas that are already more diverse (Radosevich et al. 2007), that does not seem to be the case in this lacustrine dune ecosystem (Morrison and Yarranton 1973; Kennedy et al. 2002; Marshall et al. 2008). Areas of sand stability seem to be more indicative of establishment potential rather than existing plant diversity. Areas of high spotted knapweed abundance had higher species diversity and yet a lower native dune plant species diversity.

Species evenness seems to vary across spotted knapweed abundance (Tables 4.3 and 4.4, Figure 4.12 and 4.13). Evenness of percent was highest in areas without spotted knapweed while evenness of number of individuals was highest in areas without spotted knapweed. However, the lowest evenness was consistently found in areas of low spotted knapweed. Areas of low spotted knapweed abundance seem to be less evenly distributed and may therefore indicate a transitional vegetation community.

\section{Species Comparisons}

Of the three most common dune species, Lake Huron tansy, a threatened species in the state of Michigan, occurred solely in areas in which spotted knapweed was not present. These data indicate that these species are incompatible. Graminoids seem to be compatible but unable to compete with invading species for the extent of space they occupy when spotted knapweed is not present. Percent cover of beach pea and wild sage 
were highest in areas with low spotted knapweed abundance. Beach pea was prevalent in areas without spotted knapweed, but rare in areas with high spotted knapweed. With its nitrogen-fixing characteristics, beach pea may be enabling areas that have low spotted knapweed populations to become invaded at high densities.

The three most common non-dune species were spotted knapweed, hawkweed, and red sorrel. Those three species were not present in areas of no spotted knapweed abundance. These three plants are also all considered invasive or nuisance plants by the park. Hawkweed and red sorrel are only found in areas in which spotted knapweed is present and in lower abundance than spotted knapweed, which suggests that spotted knapweed is a platform for other invading plants. Hawkweed and red sorrel were also only present in areas with spotted knapweed, but at reduced percent cover and numbers. Horsetail was only present in areas without spotted knapweed, suggesting it is a dune species; however, supporting documentation could not be found, as most species of horsetails prefer moist, shaded soils (Rook 2002). Yarrow is more common in areas that have zero to low abundance of spotted knapweed. Bearberry, lily-of-the-valley, and meadow sage only occurred in one plot, probably due to that plot's vicinity to the main road through the park. Control of spotted knapweed occurs along roadways, so spotted knapweed may have previously been in that plot, but no spotted knapweed vegetative parts, live or dead, were present.

\section{Linear Regression}

Linear regression shows that percent cover of the dune species decrease as percent of spotted knapweed increases. This suggests that as spotted knapweed invades, native dune plants cannot compete for resources. The increase in percent of non-dune species correlates to the increase of spotted knapweed percentage. This indicates that as 
spotted knapweed increases, the percent cover of non-dune species also increases. The linear regression analysis of number of individuals suggests the same trend. This supports the hypothesis that spotted knapweed may facilitate invasion by other nondune species.

\section{Summary}

Native plant interactions with environmental resource availabilities are not well understood (Maron and Marler 2007). However, native plant populations have been shown to decrease as spotted knapweed invades (Marshall et al. 2008). Spotted knapweed has a dramatic effect on native plant populations (Kedzie-Webb et al. 2001; Ortega and Pearson 2005). In a unique dune ecosystem, the effects seem to be no less dramatic. Some studies have shown that ecosystems with lower species diversity are more heavily invaded by spotted knapweed (Maron and Marler 2007) and this seems to be applicable to the Grand Sable Dunes.

Spotted knapweed can exclude other species by allelopathy, but does not seem to be limiting non-dune species in the dune ecosystems but rather seems to be enhancing habitat for those undesirable species. Areas with low abundance of spotted knapweed may have been invaded for less time than areas with high abundance of spotted knapweed. Therefore, areas with low spotted knapweed abundances may be transitional plant communities. It is unclear if or how low abundance areas will become high abundance areas. It is also unclear if the plant community would recover if spotted knapweed was removed from the system; however, if it is controlled in the dune area, the invasion will be slowed. 


\section{Acknowledgements}

We would like to thank Bruce Leutscher of Pictured Rocks National Lakeshore for his help in site selection and implementation. Thank you also to Joseph Latsch for his field skills.

\section{Literature Cited}

Bach, David P. 1978. Plant communities, habitats, and soil conditions of Grand Sable Dunes, Pictured Rocks National Lakeshore, Michigan. M.S. Thesis. Houghton, Michigan: Michigan Technological University. 180 p.

Bais, H.P., R. Vepachedu, S. Gilroy, R.M. Callaway, and J.M. Vivanco. 2003. Allelopathy and exotic plant invasion: from molectules and genes to species interactions. Science 301(5638) 1377-1380.

Bradfield, G.E. and L. Orloci. 1975. Classification of vegetation data from an open beach environment in southwestern Ontario: cluster analysis followed by generalized distance assignments. Canadian Journal of Botany 53:495-502.

Carpinelli, M. 2003. Spotted knapweed invasive exotic plant tutorial. USDA-ARS Burns, Oregon.

Michigan Department of National Resources and Environment. 2009. Michigan's Official List of Endangered and Threatened Species.

Fletcher, R.A., and A.J. Renney. 1963. A growth inhibitor found in Centaurea spp. Canadian Journal of Plant Science 43:475-481.

Garcia-Mora, M.R., J.B. Gallego-Fernandez, and F. Garcia-Novo. 200o. Plant diversity as a suitable tool for coastal dune vulnerability assessment. The Journal of Coastal Research 16: 990-995.

Hayek, L.C. and M.A. Buzas. 1997. Surveying natural populations. New York: Columbia University Press. 563 p.

Kedzie-Webb, S.A., R.L. Sheley, J.J. Borowski, and J.S. Jacobs. Relationships between Centaurea maculosa and indigenous plant assemblages. Western North American Naturalist 61(1): 43-49.

Kennedy, T.A., S. Naeem, K.M. Howe, J.M.H. Knops, D. Tilman, and P. Reigh. 2002. Biodiversity as a barrier to ecological invasion. Nature 417: 636-638.

Kumler, M.L. 1969. Plant succession of the sand dunes of the Oregon coast. Ecology 50:695-704.

Lichter, J. 2000. Colonization constraints during primary succession on coastal Lake Michigan sand dunes. Journal of Ecology 88: 825-839. 
Lym, R.G., and R.K. Zollinger. C. maculosa. 1992. North Dakota State University. http://www.ag.ndsu.edu/pubs/plantsci/weeds/w842w.htm. Accessed: April 13, 2009.

MacDonald, N.W., B.T. Scull, and S.R. Abella. 2007. Mid-spring burning reduces spotted knapweed and increases native grasses during a Michigan experimental grassland establishment. Restoration Ecology 15: 118-128.

Maron, J. and M. Marler. 2007. Native plant diversity resists invasion at both low and high resource levels. Ecology 88(10): 2651-2661.

Maron, J. and M. Marler. 2008. Field-based competitive impacts between invaders and natives at varying resource supply. Journal of Ecology 96: 1187-1197.

Marshall, J.M., A.J. Storer, and B. Leutscher. 2008. Comparative analysis of plant and ground dwelling arthropod communities in lacustrine dune areas with and without Centaurea biebersteinii (Asteraceae). The American Midland Naturalist 159(2): 261-274.

Meiners, S.J. and M.L. Cadenasso. 2005. The relationship between community diversity and exotic plants: cause or consequence of invasion? Invasive plants: Ecological and Agricultural Aspects. Pp. 97-114.

Moore, P.D. 1971. Computer analysis of sand dune vegetation in Norfolk, England, and its implications for conservation. Vegetation 23:3 23-338.

Morrison, R.G. and G.A. Yarranton. 1973. Diversity, richness, and evenness during a primary sand dune succession at Grand Bend, Ontario. The Canadian Journal of Botany. 51: 2401-2411.

Myers, J.H. and D.R. Bazely. 2003. Ecology and Control of Introduced Plants. Cambridge University Press, Cambridge, UK. 313 p.

National Park Conservation Association. 2007. State of the Parks: Pictured Rocks National Lakeshore. Pp 6-24.

Olson, J.S. 1958. Lake Michigan dune development 2: plants as agents and tools in geomorphology. Journal of Geology 66: 345-351.

Ortega, Y.K. and D.E. Pearson. 2005. Weak vs. strong invaders of natural plant communities: assessing invasibility and impact. Ecological Applications 15(2): 651-661

Pictured Rocks National Lakeshore. Grand Sable Dunes Research Natural Area. 2007. National Park Service. http://www.nps.gov/piro/naturescience/upload/ GrandSableDunesColor\%202008.pdf. Accessed: April 2009.

Rook, E.J.S. 2002. Equisteum: horsetail. www.rook.org. Accessed: April 2011.

Statistix. 2003. Statistix® 8 Analytical Software. User's Manual. Tallahassee. 396 p.

Strahler, A.N. and A.H. Strahler. 1978. Modern Physical Geography. New York, New York: Wiley. 656 p. 
United States Department of Agriculture, National Resources Conservation Service. 2011. The PLANTS Database National Plant Data Center, Baton Rouge, LA, USA. http://plants.usda.gov. Accessed: March 19, 2011.

Van der Valk, A.G. 1974. Environmental factors controlling the distribution of forbs on coastal foredunes in Cape Hatteras National Seashore. Canadian Journal of Botany 52:1 057-1073.

Watson, A.K. and A.J. Renney. 1974. The biology of Canadian weeds Centaurea diffusa and C. maculosa. Canadian Journal of Plant Science 54: 687-701.

Weir, T.L., H.P. Bais, and J.M. Vivanco. 2003. Intraspecific and interspecific interactions mediated by a phytotoxin, (-)-catechin, secreted by the roots of Centaurea maculosa (spotted knapweed). Journal of Chemical Ecology 29(11) 2397-2412.

Willis, A.J., B.F. Folkes, J.F. Hope-Simpson, and E.W. Yemm. 1959. Braunton Burrows: the dune system at its vegetation. Ecology 47:1-24,249-288. 
Table 4.1. Plant species identified and quantified in study of the impacts of spotted knapweed in a shifting dune ecosystem at Pictured Rocks National Lakeshore, Alger County, Michigan. Plants are separated into native dune species, species native to the area but not to the dunes, and species exotic to the area.

\begin{tabular}{|c|c|}
\hline Species & Common Name \\
\hline \multicolumn{2}{|l|}{ Native Dune Plants } \\
\hline $\begin{array}{l}\text { Artemisia spp. L. } \\
\text { Fragaria vesca L. } \\
\text { Lathyrus japonicas Willd. } \\
\text { Lithosperumm caroliniense Walter ex J.F. Gmel. } \\
\text { Maianthemum stellatum L. } \\
\text { Oenothera parviflora L. } \\
\text { Poaceae or Cyperaceae } \\
\text { Prunus pumila L. } \\
\text { Rosa blanda Aiton } \\
\text { Stellaria longipes Goldie } \\
\text { Tanacetum huronense Nutt. }\end{array}$ & $\begin{array}{l}\text { Wild sage } \\
\text { Wild strawberry } \\
\text { Beach pea } \\
\text { Puccoon } \\
\text { Starry false Solomon's } \\
\text { seal } \\
\text { Evening primrose } \\
\text { Graminoid } \\
\text { Dune cherry } \\
\text { Smooth rose } \\
\text { Dune stitchwort } \\
\text { Lake Huron tansy } \\
\end{array}$ \\
\hline \multicolumn{2}{|l|}{ Non-dune Plants } \\
\hline $\begin{array}{l}\text { Achillea millefolium } \mathrm{L} . \\
\text { Arctostaphylos uva-ursi L. } \\
\text { Asclepias syriaca L. } \\
\text { Convallaria majalis L. } \\
\text { Equisetum arvense L. } \\
\text { Leucanthemum vulgare Lam. } \\
\text { Lychnis alba Mill. } \\
\text { Plantago major L. } \\
\text { Potentilla spp. L. } \\
\text { Salvia vesticillata } \mathrm{L} . \\
\text { Solidago spp. L. } \\
\text { Toxicodendron radicans L. Kuntze } \\
\text { Trifolium repens L. }\end{array}$ & $\begin{array}{l}\text { Yarrow } \\
\text { Bearberry } \\
\text { Milkweed } \\
\text { Lily-of-the-valley } \\
\text { Horsetail } \\
\text { Ox-eye daisy } \\
\text { White campion } \\
\text { Plantain } \\
\text { Cinquefoil } \\
\text { Meadow sage } \\
\text { Goldenrod } \\
\text { Poison ivy } \\
\text { White clover } \\
\end{array}$ \\
\hline \multicolumn{2}{|l|}{ Exotic Plants } \\
\hline $\begin{array}{l}\text { Arabis lyrata } \mathrm{L} . \\
\text { Centaurea maculosa } \mathrm{Lam} . \\
\text { Hieracium spp. L. } \\
\text { Hypericum perforatum } \mathrm{L} . \\
\text { Rumex acetosella } \mathrm{L} . \\
\text { Trifolium pretense } \mathrm{L} . \\
\end{array}$ & $\begin{array}{l}\text { Rockcress } \\
\text { Spotted knapweed } \\
\text { Hawkweed } \\
\text { St. John's wort } \\
\text { Red sorrel } \\
\text { Red clover } \\
\end{array}$ \\
\hline
\end{tabular}


Table 4.2. Mean percent cover and mean number of individuals for 100\% composition of dune and non-dune plant species in areas with different levels of spotted knapweed abundance $(\mathrm{df}=1,134)$ in the Grand Sable Dunes, Alger County, Michigan.

\begin{tabular}{|c|c|c|c|c|c|c|}
\hline \multirow[b]{2}{*}{ Percent Cover } & \multicolumn{3}{|c|}{ C. maculosa Density } & \multirow[b]{2}{*}{ SE } & \multirow{2}{*}{$\begin{array}{c}\text { Contrast: } \\
\text { Zero SK } \\
\text { vs. SK }\end{array}$} & \multirow{2}{*}{$\begin{array}{c}\text { Contrast: } \\
\text { Low SK vs. } \\
\text { High SK } \\
\end{array}$} \\
\hline & Zero & Low & High & & & \\
\hline Dune Plants & 0.02 & 0.01 & 0.01 & 0.00 & 0.056 & 0.876 \\
\hline Non-dune plants & 0.00 & 0.02 & 0.04 & 0.00 & $<0.001$ & $<0.001$ \\
\hline Non-dune plants (SK ex.) & 0.00 & 0.00 & 0.00 & 0.00 & 0.082 & 0.553 \\
\hline \multicolumn{7}{|l|}{ Number of Individuals } \\
\hline Dune Plants & 0.57 & 0.22 & 0.24 & 0.06 & 0.112 & 0.986 \\
\hline Non-dune plants & 0.05 & 0.31 & 0.74 & 0.04 & 0.066 & 0.032 \\
\hline Non-dune plants (SK ex.) & 0.06 & 0.21 & 0.35 & 0.04 & 0.060 & 0.374 \\
\hline
\end{tabular}

Table 4.3. Richness, diversity, and evenness of mean percent cover in areas with different levels of spotted knapweed $(\mathrm{df}=1,134)$ in the Grand Sable Dunes, Alger County, Michigan.

\begin{tabular}{lcccccc}
\hline & \multicolumn{4}{c}{ C. maculosa Density } & & \multicolumn{2}{c}{$\begin{array}{c}\text { Contrast 1: } \\
\text { No SK }\end{array}$} & $\begin{array}{c}\text { Contrast 2: } \\
\text { Low SK vs. } \\
\end{array}$ & Zero & Low & High & SE & vs. SK & High SK \\
\hline Richness & 2.93 & 4.64 & 5.24 & 0.284 & $<\mathbf{0 . 0 0 1}$ & 0.126 \\
Diversity & 0.39 & 0.47 & 0.80 & 0.044 & $<\mathbf{0 . 0 0 1}$ & $<\mathbf{0 . 0 0 1}$ \\
Evenness & 0.13 & 0.10 & 0.16 & 0.011 & 0.979 & $<\mathbf{0 . 0 0 1}$ \\
\hline
\end{tabular}

Table 4.4. Richness, diversity, and evenness of mean number of individuals in areas with different levels of spotted knapweed $(\mathrm{df}=1,134)$ in the Grand Sable Dunes, Alger County, Michigan.

\begin{tabular}{lcccccc}
\hline & \multicolumn{4}{c}{ C. maculosa Density } & & \multicolumn{2}{c}{$\begin{array}{c}\text { Contrast 1: } \\
\text { No SK }\end{array}$} & $\begin{array}{c}\text { Contrast 2: } \\
\text { Low SK vS. } \\
\end{array}$ & Zero & Low & High & SE & vs. SK & High SK \\
\hline Richness & 2.93 & 4.64 & 5.24 & 0.284 & $<\mathbf{0 . 0 0 1}$ & 0.126 \\
Diversity & 0.61 & 0.78 & 1.13 & 0.066 & $<\mathbf{0 . 0 0 1}$ & $<\mathbf{0 . 0 0 1}$ \\
Evenness & 0.35 & 0.23 & 0.29 & 0.033 & $\mathbf{0 . 0 1 1}$ & 0.226 \\
\hline
\end{tabular}


Table 4.5. Mean percent cover for dune and non-dune plant species in areas with different levels of spotted knapweed $(\mathrm{df}=1,134)$ in the Grand Sable Dunes, Alger County, Michigan. Plants are separated into native dune species and non-dune species, which includes species native to the area but not to the dunes and species exotic to the area.

\begin{tabular}{|c|c|c|c|c|c|c|}
\hline \multirow[b]{2}{*}{ Species } & \multicolumn{3}{|c|}{ C. maculosa Density } & \multirow[b]{2}{*}{ SE } & \multirow{2}{*}{$\begin{array}{r}\text { Contrast 1: } \\
\text { No SK vs. } \\
\text { SK } \\
\end{array}$} & \multirow{2}{*}{$\begin{array}{r}\text { Contrast 2: } \\
\text { Low SK vs. } \\
\text { High SK } \\
\end{array}$} \\
\hline & No & Low & High & & & \\
\hline \multicolumn{7}{|c|}{ \% Native Dune Plants } \\
\hline Beach pea & 0.87 & 1.63 & 0.10 & 0.06 & 0.808 & 0.002 \\
\hline Dune cherry & 0.00 & 0.00 & 0.50 & 0.02 & 0.023 & $<0.001$ \\
\hline Dune stitchwort & 0.00 & 0.00 & 0.01 & 0.01 & 0.781 & 0.482 \\
\hline Evening primrose & 0.00 & 0.00 & 0.00 & 0.00 & 0.409 & 0.911 \\
\hline Graminoid & 61.13 & 40.49 & 23.46 & 0.15 & $<0.001$ & $<0.001$ \\
\hline Lake Huron tansy & 5.07 & 0.00 & 0.00 & 0.04 & $<0.001$ & 0.999 \\
\hline Puccoon & 0.00 & 0.00 & 0.01 & 0.00 & 0.445 & 0.807 \\
\hline $\begin{array}{l}\text { Smooth rose } \\
\text { Starry false }\end{array}$ & 0.39 & 0.00 & 0.77 & 0.04 & 0.557 & 0.001 \\
\hline Solomon's seal & 0.92 & 0.00 & 0.24 & 0.03 & 0.001 & 0.053 \\
\hline Wild sage & 0.02 & 0.59 & 0.00 & 0.01 & 0.034 & $<0.001$ \\
\hline Wild strawberry & 0.02 & 0.00 & 0.12 & 0.02 & 0.932 & 0.051 \\
\hline \multicolumn{7}{|l|}{ \% Non-dune plants } \\
\hline Bearberry & 0.02 & 0.00 & 0.00 & 0.02 & 0.381 & 1.000 \\
\hline Cinquefoil & 0.00 & 0.00 & 0.00 & 0.00 & 0.600 & 0.228 \\
\hline Goldenrod & 0.04 & 0.10 & 0.01 & 0.01 & 0.998 & 0.127 \\
\hline Hawkweed & 0.00 & 1.37 & 3.45 & 0.04 & $<0.001$ & $\mathbf{0 . 0 0 7}$ \\
\hline Horsetail & 0.17 & 0.00 & 0.00 & 0.01 & 0.001 & 1.000 \\
\hline Lily-of-the-valley & 0.00 & 0.00 & 0.00 & 0.00 & 0.381 & 1.000 \\
\hline Meadow sage & 0.01 & 0.00 & 0.00 & 0.00 & 0.381 & 1.000 \\
\hline Milkweed & 0.00 & 0.00 & 0.01 & 0.00 & 0.461 & 0.110 \\
\hline Ox-eye daisy & 0.00 & 0.00 & 0.00 & 0.00 & 0.781 & 0.482 \\
\hline Plantain & 0.00 & 0.00 & 0.00 & 0.00 & 0.381 & 1.000 \\
\hline Poison ivy & 0.03 & 0.00 & 0.04 & 0.03 & 0.878 & 0.474 \\
\hline Red clover & 0.00 & 0.03 & 0.00 & 0.01 & 0.475 & 0.119 \\
\hline Red sorrel & 0.01 & 1.98 & 5.29 & 0.07 & $<0.001$ & $\mathbf{0 . 0 0 7}$ \\
\hline Rockcress & 0.00 & 0.01 & 0.00 & 0.00 & 0.214 & 0.401 \\
\hline Spotted knapweed & 0.00 & 2.89 & 23.03 & 0.08 & $<0.001$ & $<0.001$ \\
\hline St. John's wort & 0.00 & 0.00 & 0.00 & 0.00 & 0.381 & 1.000 \\
\hline White campion & 0.00 & 0.00 & 0.02 & 0.01 & 0.909 & 0.351 \\
\hline White clover & 0.00 & 0.01 & 0.00 & 0.00 & 0.372 & 0.062 \\
\hline Yarrow & 0.00 & 0.01 & 0.00 & 0.00 & 0.818 & 0.447 \\
\hline
\end{tabular}


Table 4.6. Mean number of individuals for dune and non-dune plant species in areas with different levels of spotted knapweed $(\mathrm{df}=1,134)$ in the Grand Sable Dunes, Alger County, Michigan. Plants are separated into native dune species and non-dune species, which includes species native to the area but not to the dunes and species exotic to the area.

\begin{tabular}{|c|c|c|c|c|c|c|}
\hline \multirow[b]{2}{*}{ Species } & \multicolumn{3}{|c|}{ C. maculosa Density } & \multirow[b]{2}{*}{ SE } & \multirow{2}{*}{$\begin{array}{r}\text { Contrast 1: } \\
\text { No SK } \\
\text { vs. SK } \\
\end{array}$} & \multirow{2}{*}{$\begin{array}{r}\text { Contrast 2: } \\
\text { Low SK } \\
\text { vs. High SK } \\
\end{array}$} \\
\hline & Zero & Low & High & & & \\
\hline \multicolumn{7}{|c|}{ Native Dune Plants } \\
\hline Beach pea & 0.59 & 0.79 & 0.12 & 0.242 & 0.668 & 0.012 \\
\hline Dune cherry & 0.00 & 0.01 & 0.16 & 0.004 & 0.035 & 0.001 \\
\hline Dune stitchwort & 0.00 & 0.00 & 0.01 & 0.023 & 0.781 & 0.482 \\
\hline Evening primrose & 0.00 & 0.01 & 0.01 & 0.108 & 0.413 & 0.917 \\
\hline Graminoid & 32.41 & 29.13 & 20.27 & 0.11 & 0.023 & 0.013 \\
\hline Lake Huron tansy & $4 \cdot 39$ & 0.00 & 0.00 & 0.144 & $<0.001$ & 1.000 \\
\hline Puccoon & 0.00 & 0.01 & 0.03 & 0.072 & 0.494 & 0.697 \\
\hline $\begin{array}{l}\text { Smooth rose } \\
\text { Starry false }\end{array}$ & 0.42 & 0.00 & 0.70 & 0.008 & 0.934 & $<0.001$ \\
\hline Solomon's seal & 1.16 & 0.01 & 0.50 & 0.006 & 0.001 & 0.066 \\
\hline Wild sage & 0.09 & 0.57 & 0.02 & 0.010 & 0.149 & $<0.001$ \\
\hline Wild strawberry & 0.04 & 0.01 & 0.11 & 0.067 & 0.844 & 0.112 \\
\hline \multicolumn{7}{|l|}{ Non-dune plants } \\
\hline Bearberry & 0.13 & 0.00 & 0.00 & 0.023 & 0.381 & 1.000 \\
\hline Cinquefoil & 0.02 & 0.00 & 0.00 & 0.011 & 0.594 & 0.222 \\
\hline Goldenrod & 0.17 & 0.14 & 0.04 & 0.002 & 0.657 & 0.580 \\
\hline Hawkweed & 0.00 & 1.92 & 4.79 & 0.019 & $<0.001$ & 0.003 \\
\hline Horsetail & 0.55 & 0.00 & 0.00 & 0.013 & $\mathbf{0 . 0 0 1}$ & 1.000 \\
\hline Lily-of-the-valley & 0.04 & 0.00 & 0.00 & 0.024 & 0.381 & 1.000 \\
\hline Meadow sage & 0.02 & 0.00 & 0.00 & 0.251 & 0.381 & 1.000 \\
\hline Milkweed & 0.00 & 0.00 & 0.02 & 0.067 & 0.482 & 0.124 \\
\hline Ox-eye daisy & 0.01 & 0.00 & 0.00 & 0.007 & 0.781 & 0.482 \\
\hline Plantain & 0.00 & 0.00 & 0.00 & 0.085 & 0.381 & 1.000 \\
\hline Poison ivy & 0.02 & 0.00 & 0.04 & 0.060 & 0.994 & 0.425 \\
\hline Red clover & 0.00 & 0.07 & 0.00 & 0.006 & 0.536 & 0.166 \\
\hline Red sorrel & 0.09 & 3.24 & 7.13 & 0.116 & $<0.001$ & 0.010 \\
\hline Rockcress & 0.00 & 0.20 & 0.04 & 0.078 & 0.390 & 0.327 \\
\hline Spotted knapweed & 0.00 & $3 \cdot 37$ & 20.83 & 0.194 & $<0.001$ & $<0.001$ \\
\hline St. John's wort & 0.01 & 0.00 & 0.00 & 0.084 & 0.381 & 1.000 \\
\hline White campion & 0.00 & 0.04 & 0.01 & 0.043 & 0.939 & 0.360 \\
\hline White clover & 0.00 & 0.06 & 0.00 & 0.018 & 0.434 & 0.094 \\
\hline Yarrow & 0.05 & 0.03 & 0.00 & 0.028 & 0.549 & 0.794 \\
\hline
\end{tabular}




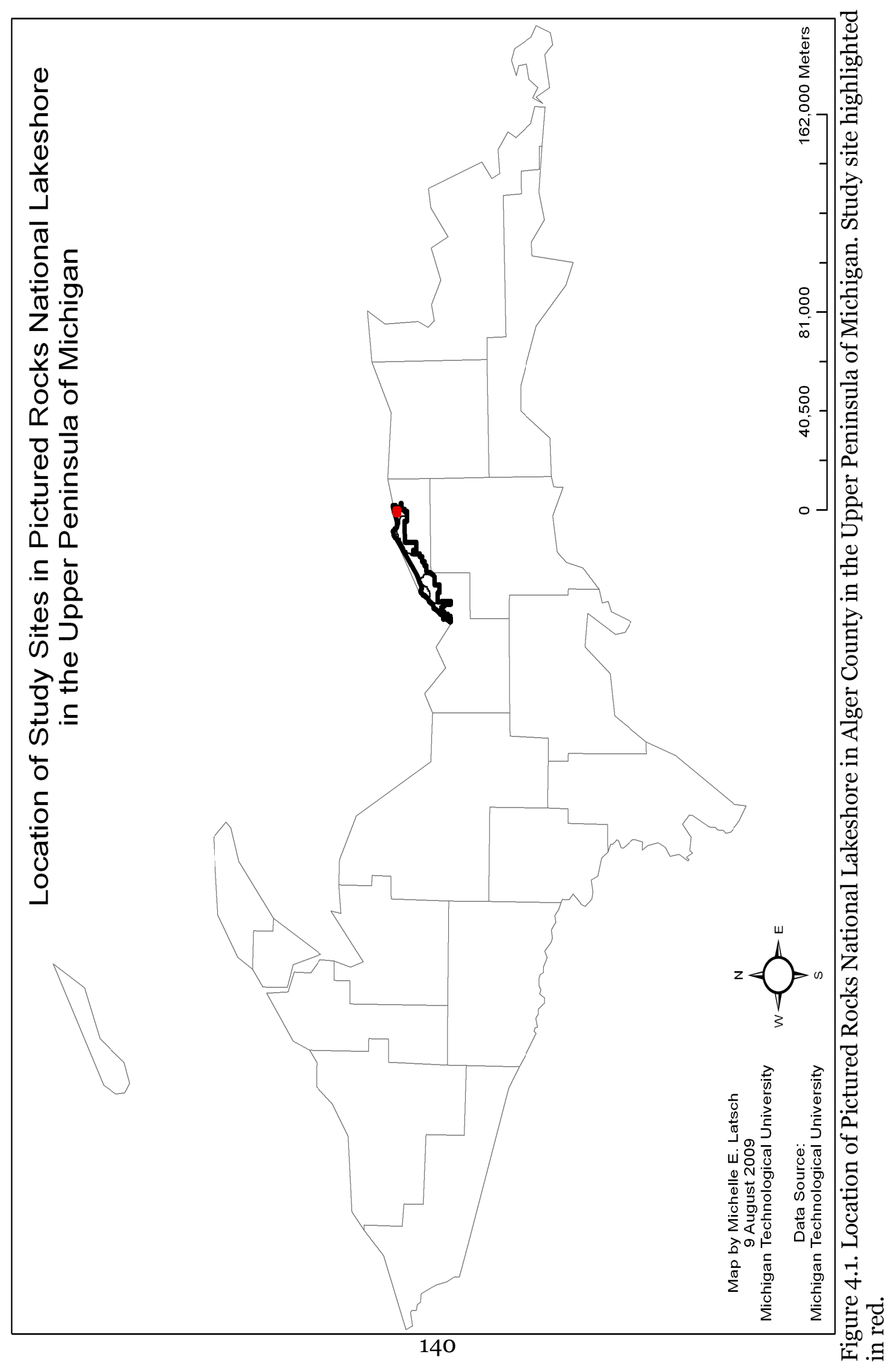




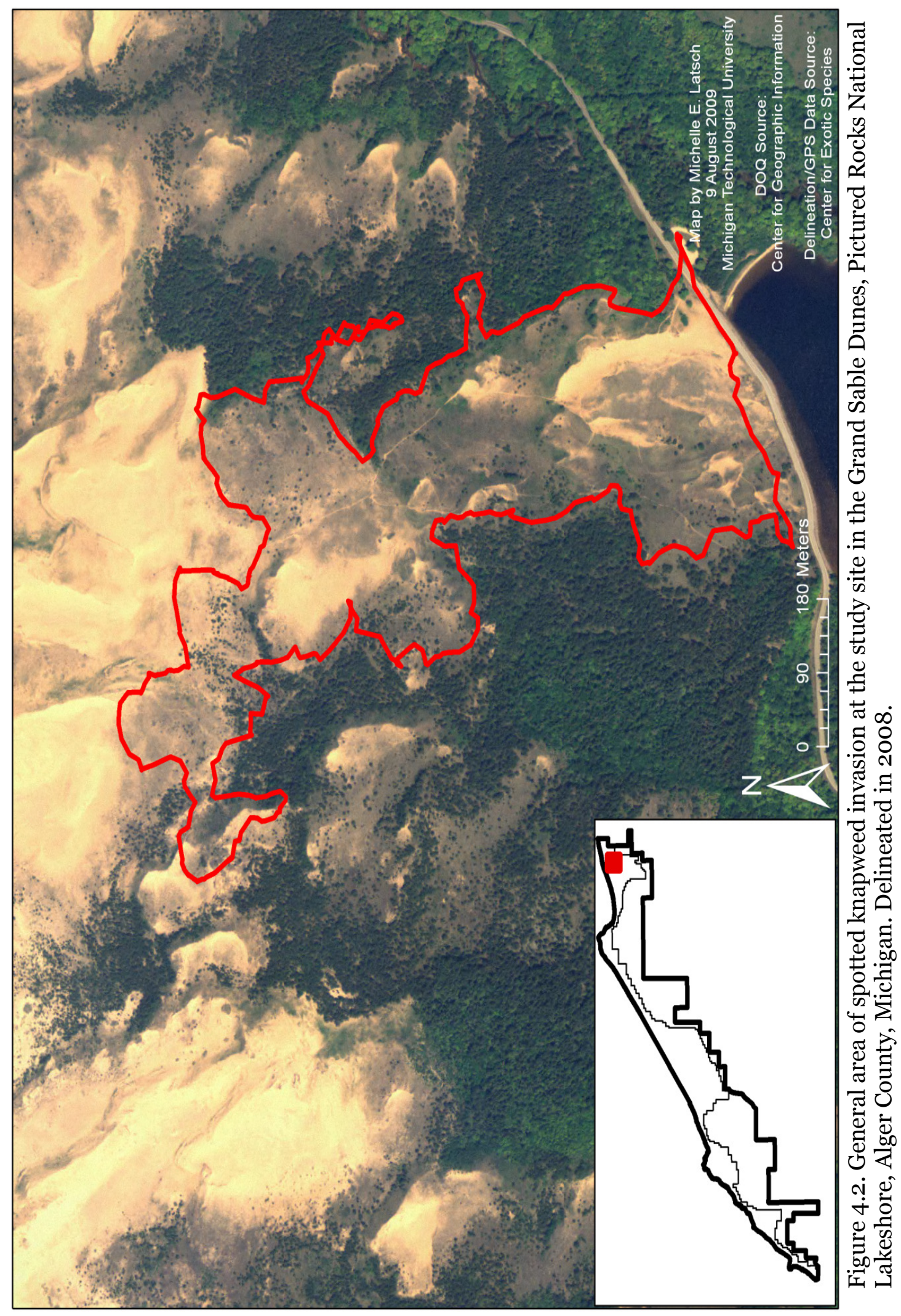




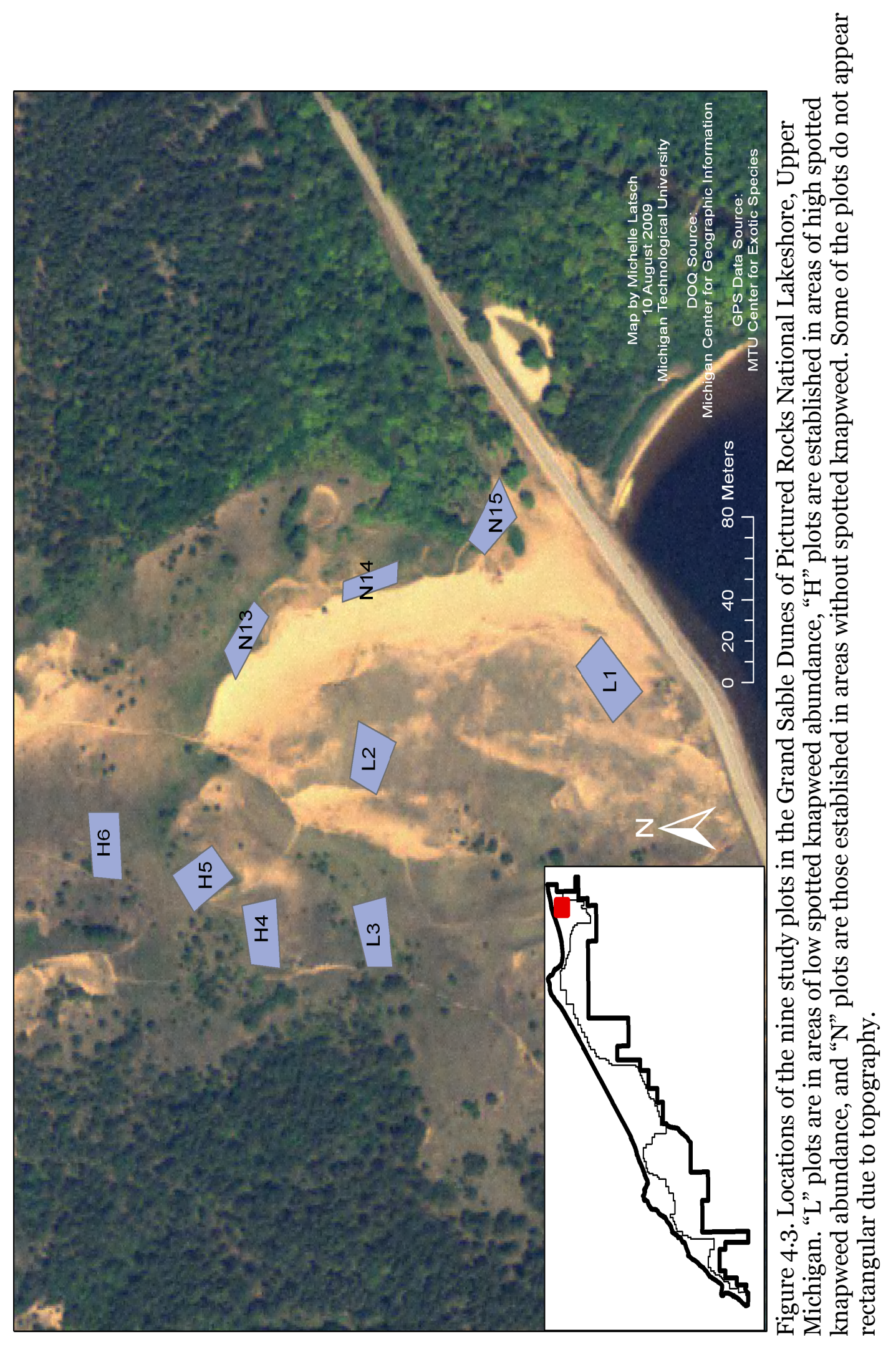




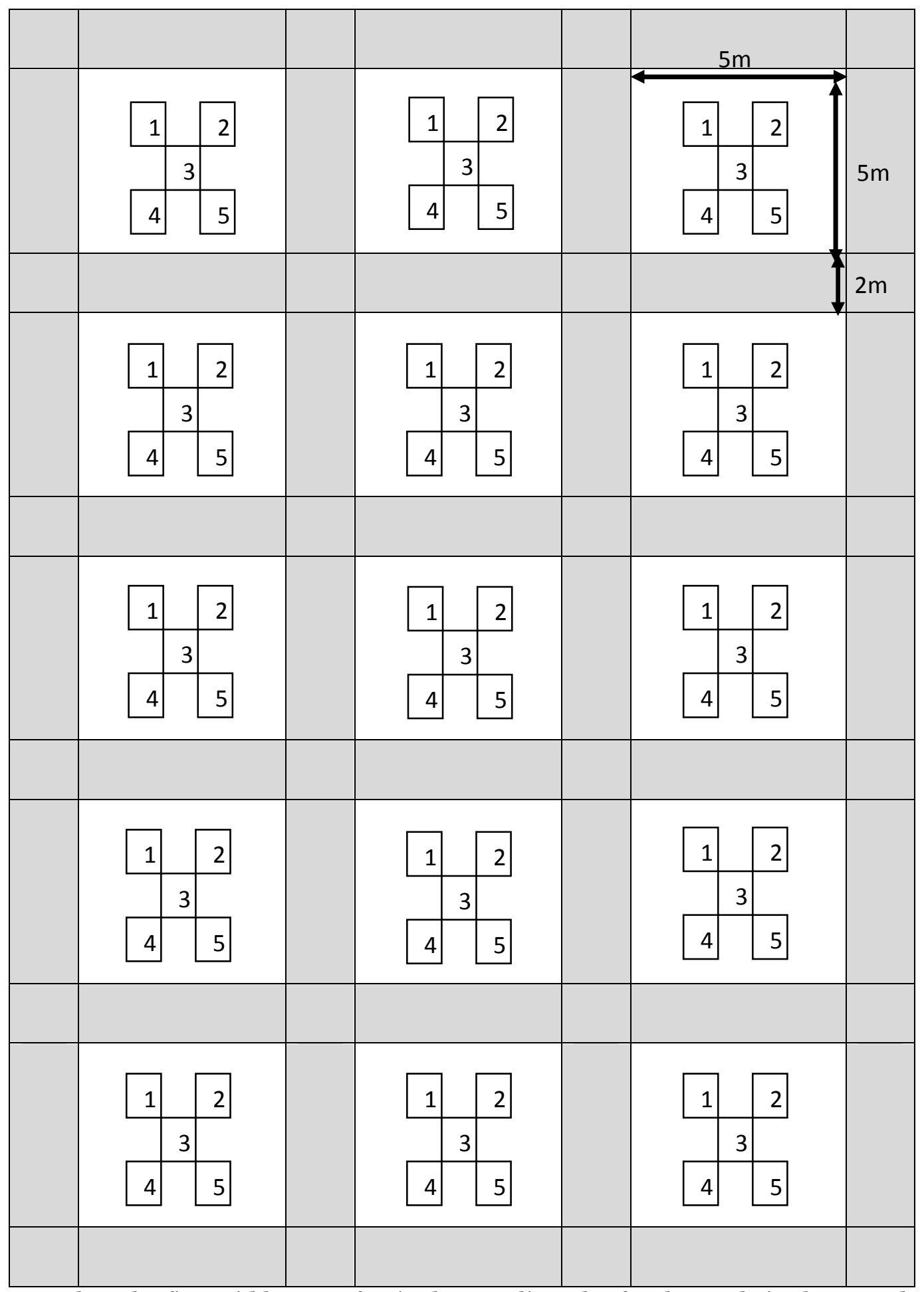

Figure 4.4. Three by five grid layout of a single sampling plot for the study in the Grand Sable Dunes of Pictured Rocks National Lakeshore, Michigan. Gray areas indicate 2 meter buffer areas between subplots and around plots. Numbered squares are the layout of the sampling quadrats within each subplot. 


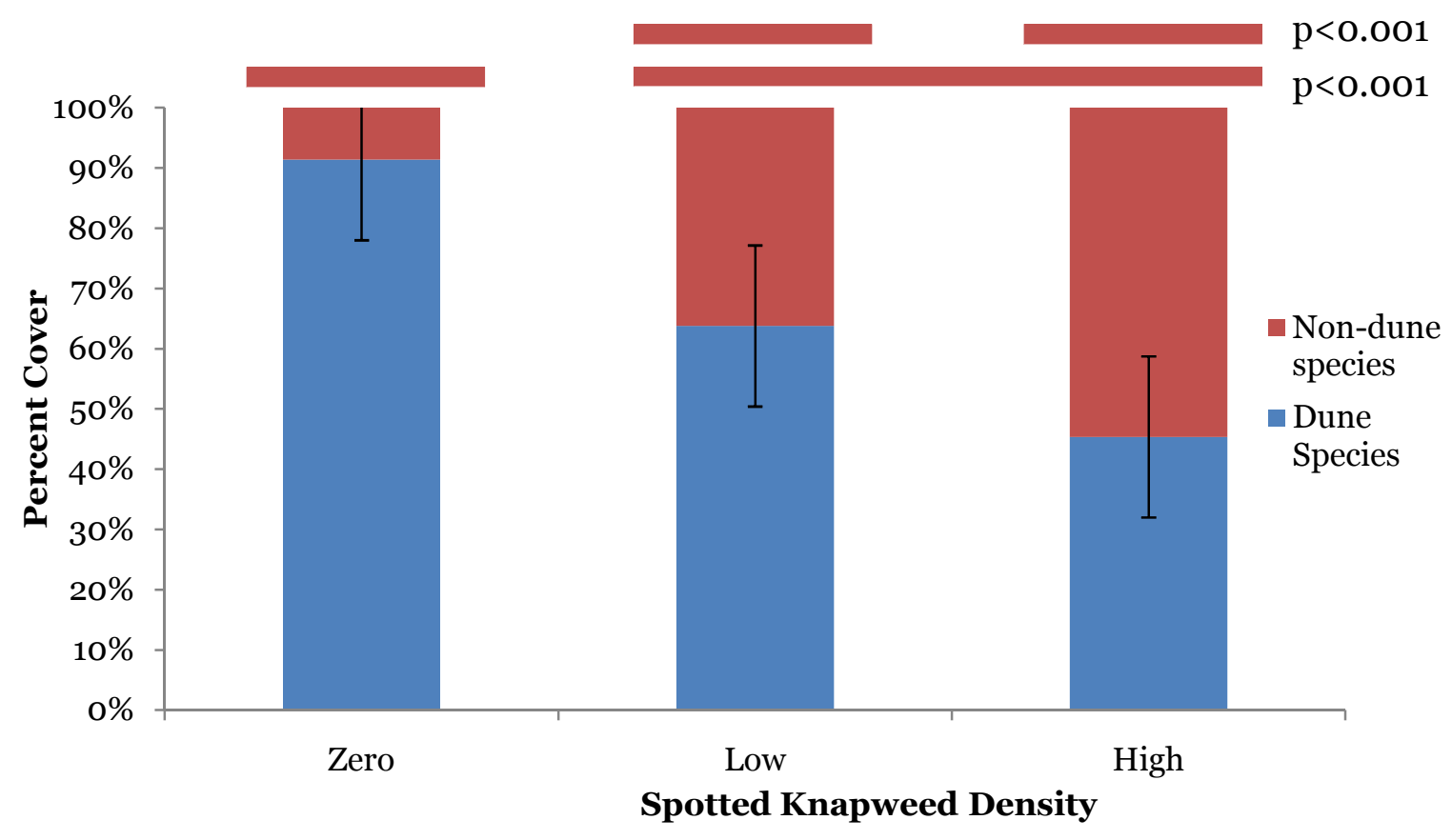

Figure 4.5. Percent cover of dune and non-dune plant species in areas with varying densities of spotted knapweed in the Grand Sable Dunes of Pictured Rocks National Lakeshore in Upper Michigan, USA. Error bars represent standard error for the percent of dune species. Spotted knapweed is included in the data for non-dune plants.

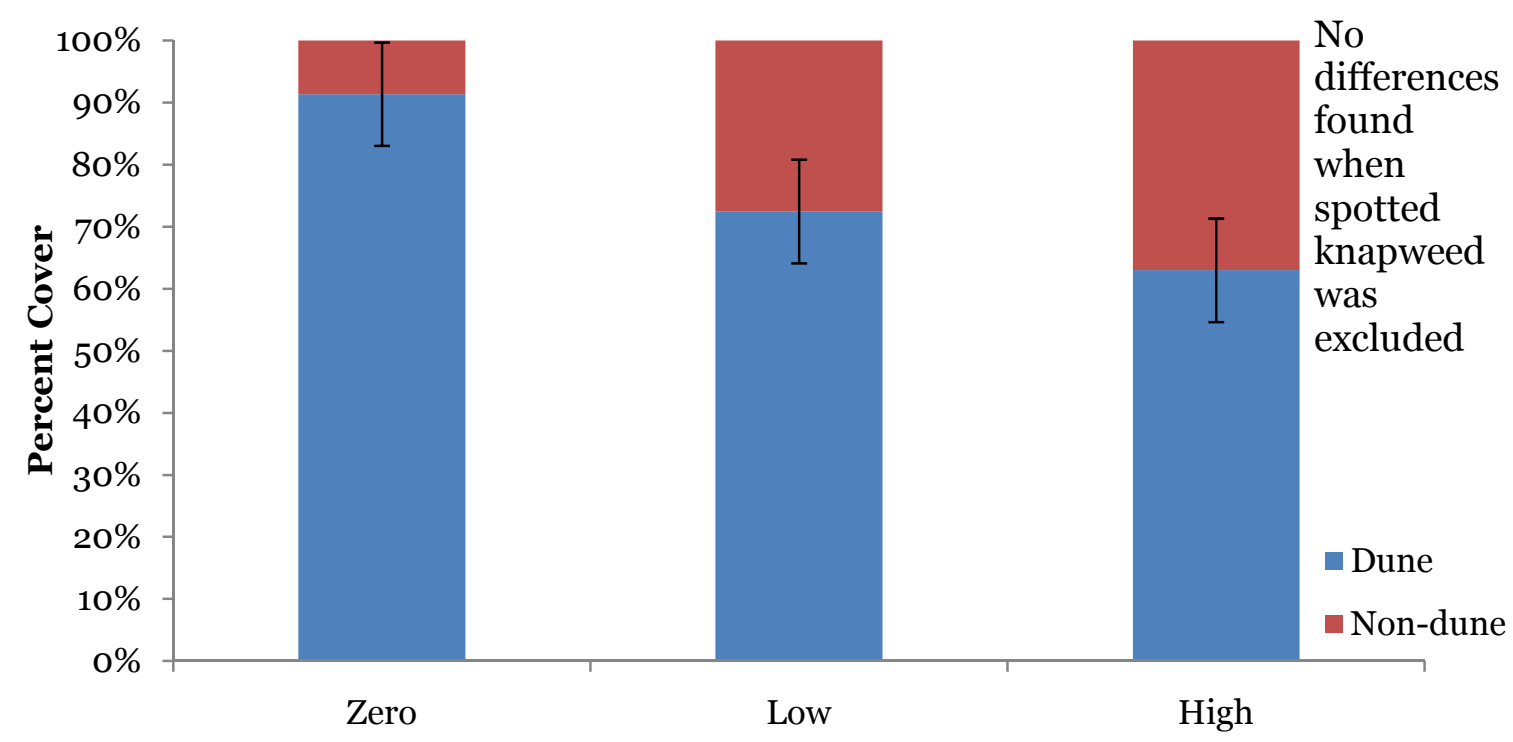

\section{Spotted Knapweed Density}

Figure 4.6. Percent cover of dune and non-dune plant species in areas with varying densities of spotted knapweed in the Grand Sable Dunes of Pictured Rocks National Lakeshore in Upper Michigan, USA. Error bars represent standard error for the percent of dune species. Spotted knapweed is not included in the data. 


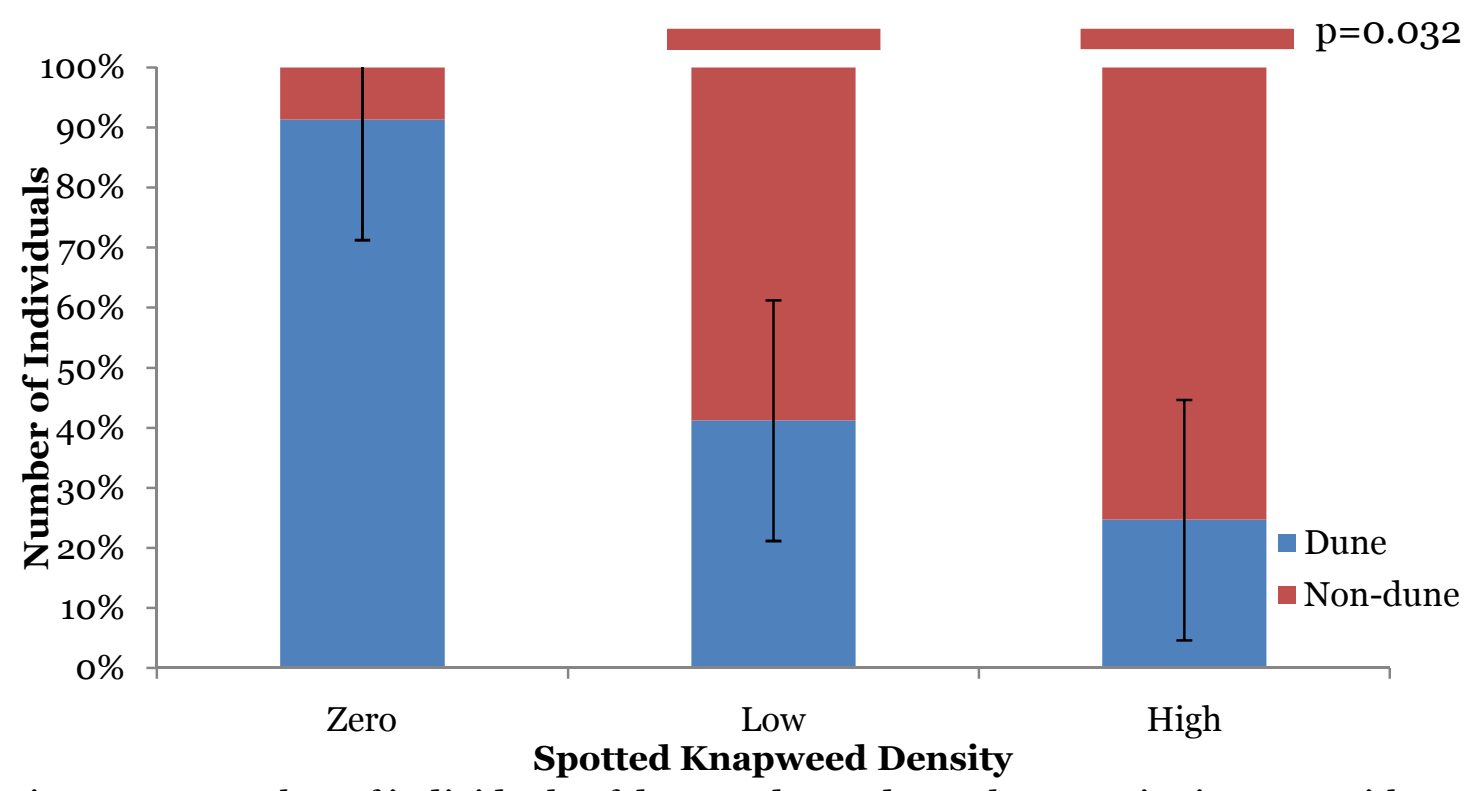

Figure 4.7. Number of individuals of dune and non-dune plant species in areas with varying densities of spotted knapweed in the Grand Sable Dunes of Pictured Rocks National Lakeshore in Upper Michigan, USA. Error bars represent standard error for the percent of dune species. Spotted knapweed is included in the data for non-dune plants.

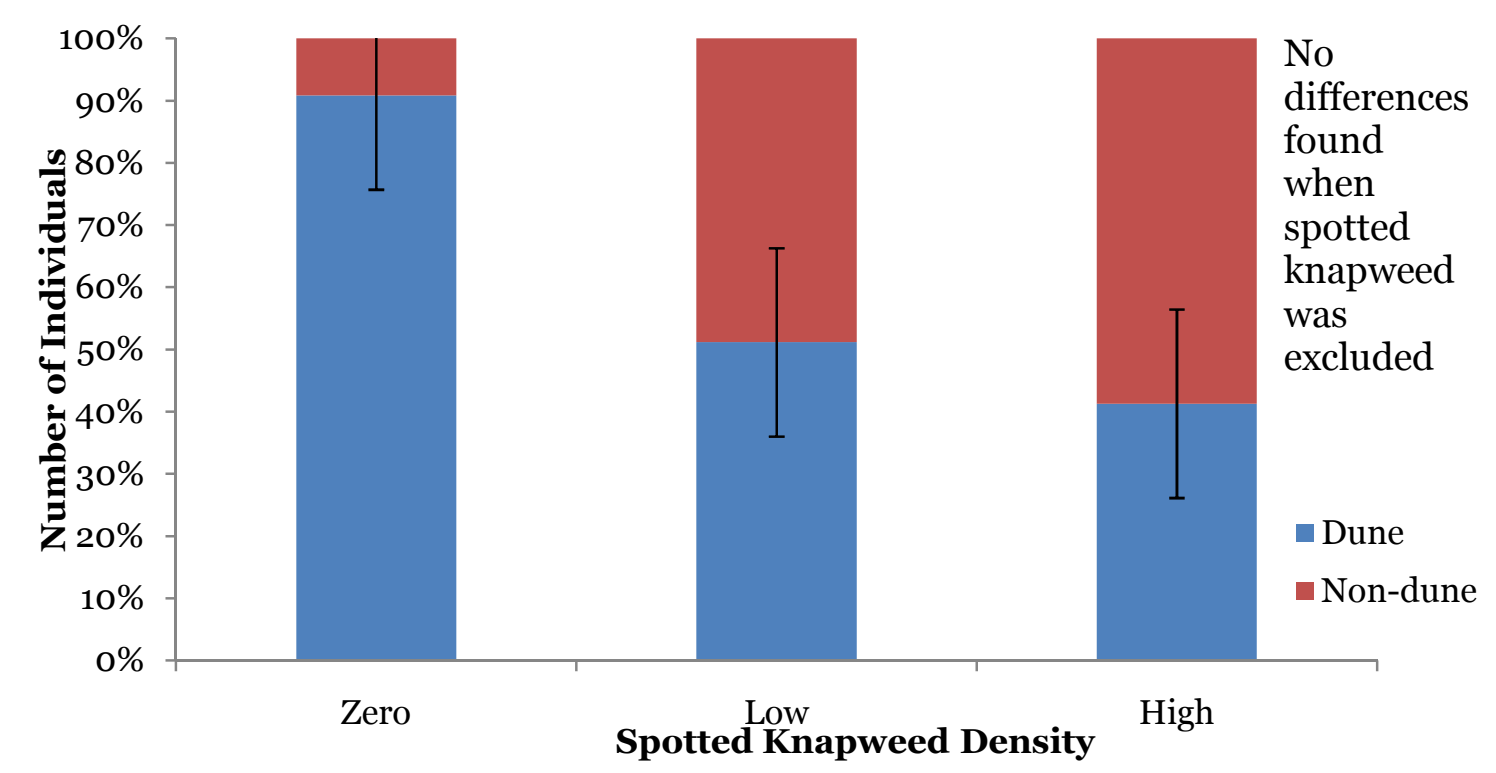

Figure 4.8. Number of individuals of dune and non-dune plant species in areas with varying densities of spotted knapweed in the Grand Sable Dunes of Pictured Rocks National Lakeshore in Upper Michigan, USA. Error bars represent standard error for the percent of dune species. Spotted knapweed is not included in the data. 


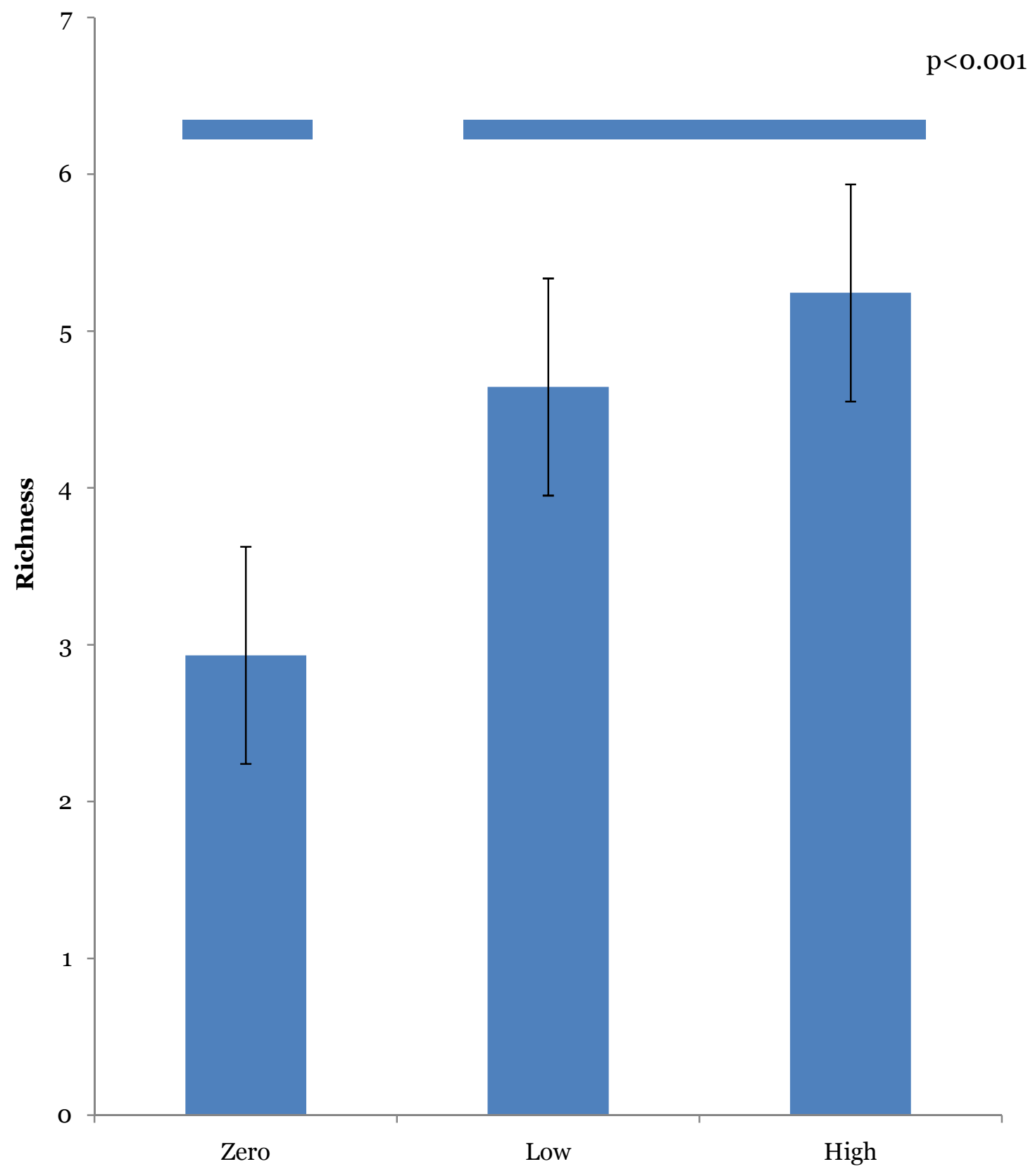

Spotted Knapweed Density

Figure 4.9. Species richness of percent cover for each abundance level in areas with varying densities of spotted knapweed in the Grand Sable Dunes of Pictured Rocks National Lakeshore in Upper Michigan, USA. Horizontal lines above the bars show differences resulting from contrasts and associated p-values. 


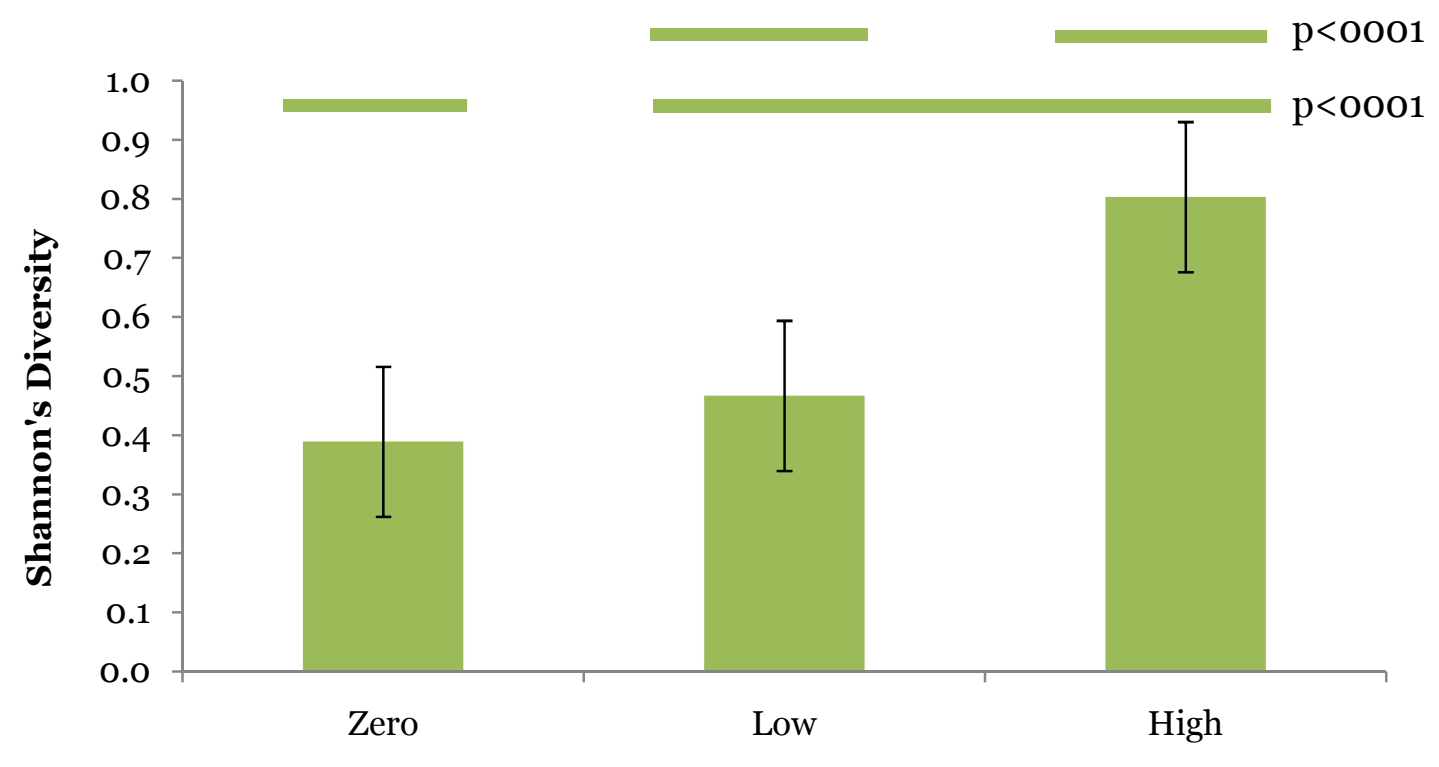

Spotted Knapweed Density

Figure 4.10. Species diversity of percent cover for each abundance level in areas with varying densities of spotted knapweed in the Grand Sable Dunes of Pictured Rocks National Lakeshore in Upper Michigan, USA. Horizontal lines above the bars show differences between areas with and without spotted knapweed as well as between areas of low and high spotted knapweed abundance. Associated p-values are also shown.

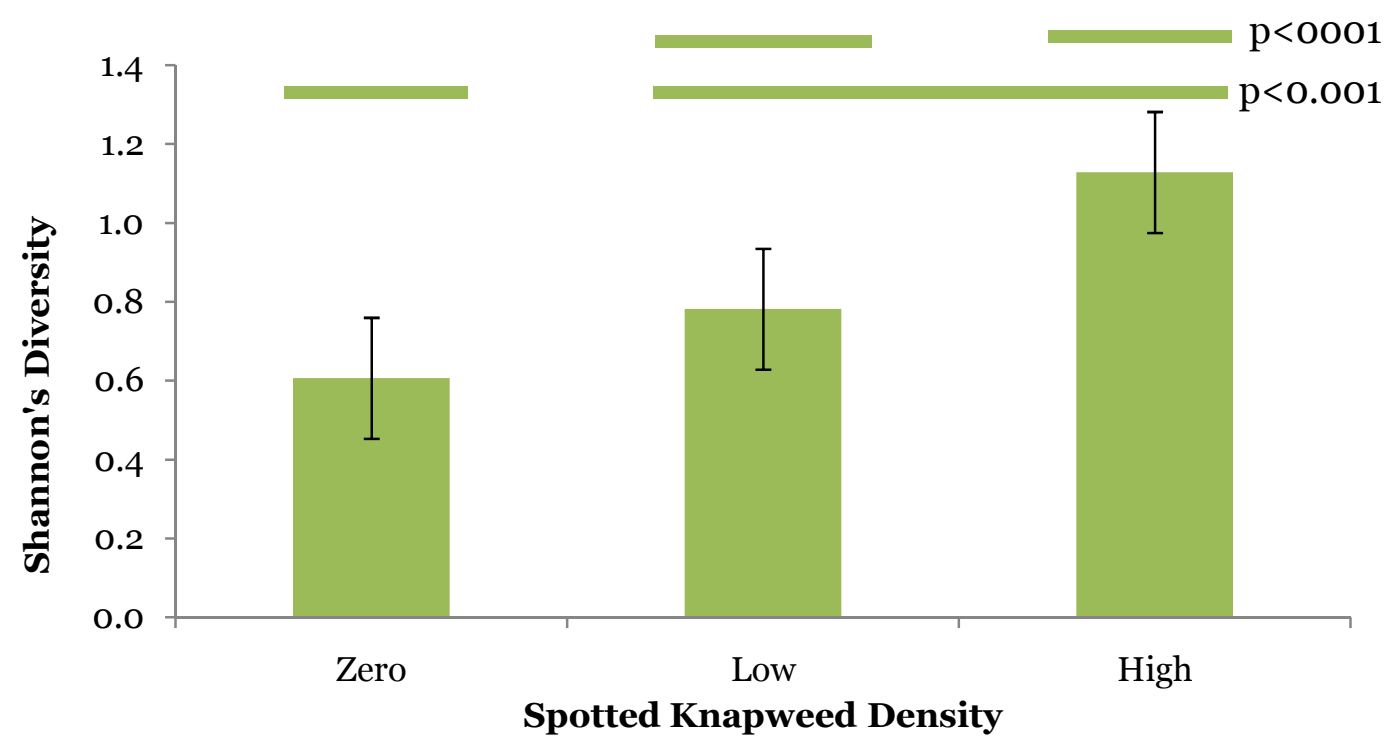

Figure 4.11. Species diversity of number of individuals for each abundance level in areas with varying densities of spotted knapweed in the Grand Sable Dunes of Pictured Rocks National Lakeshore in Upper Michigan, USA. Horizontal lines above the bars show differences between areas with and without spotted knapweed as well as between areas of low and high spotted knapweed abundance. Associated p-values are also shown. 


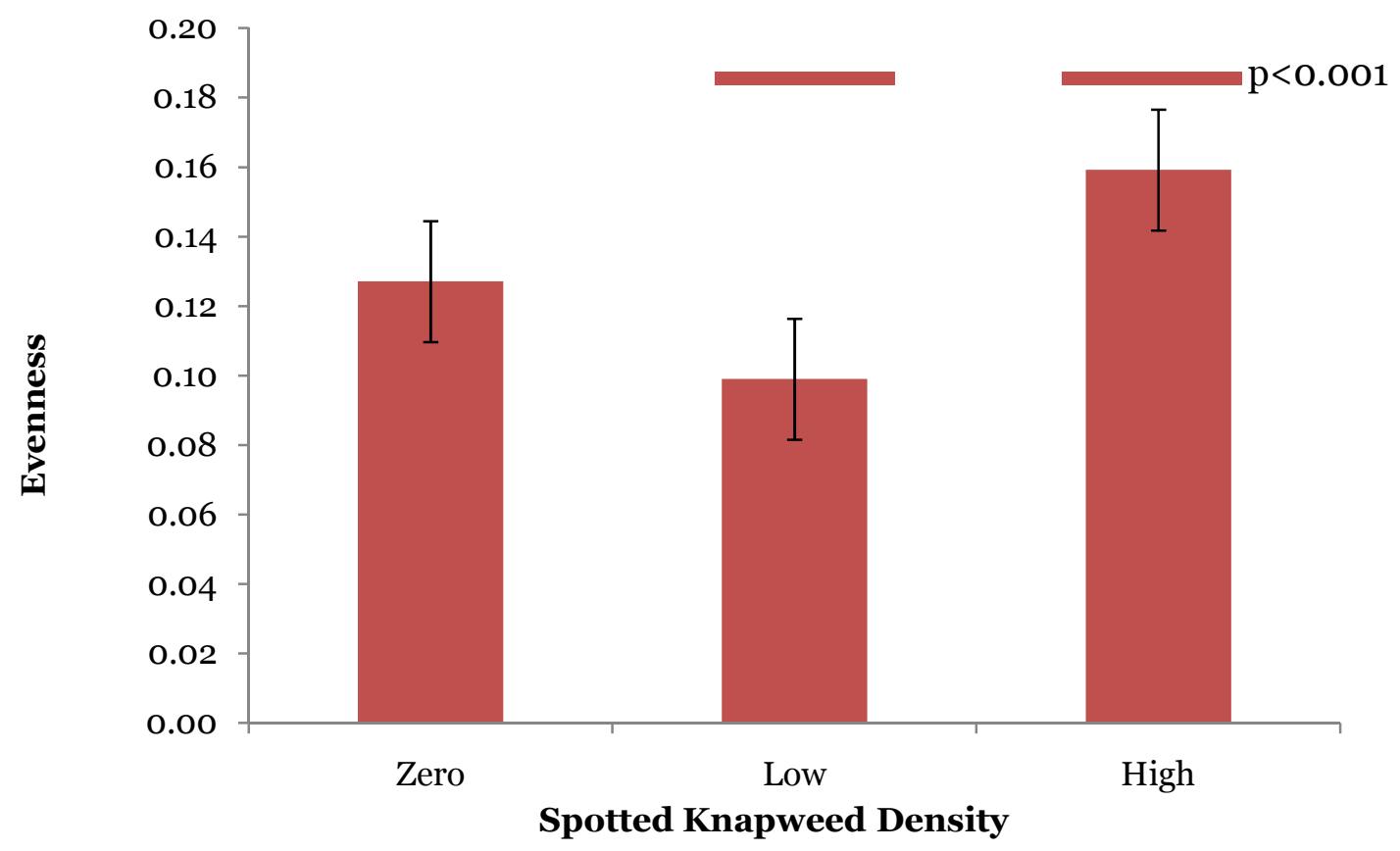

Figure 4.12. Evenness of percent cover for each abundance level in areas with varying densities of spotted knapweed in the Grand Sable Dunes of Pictured Rocks National Lakeshore in Upper Michigan, USA. Horizontal lines above the bars show difference between areas of low and high spotted knapweed abundance. The associated p-value is also shown.

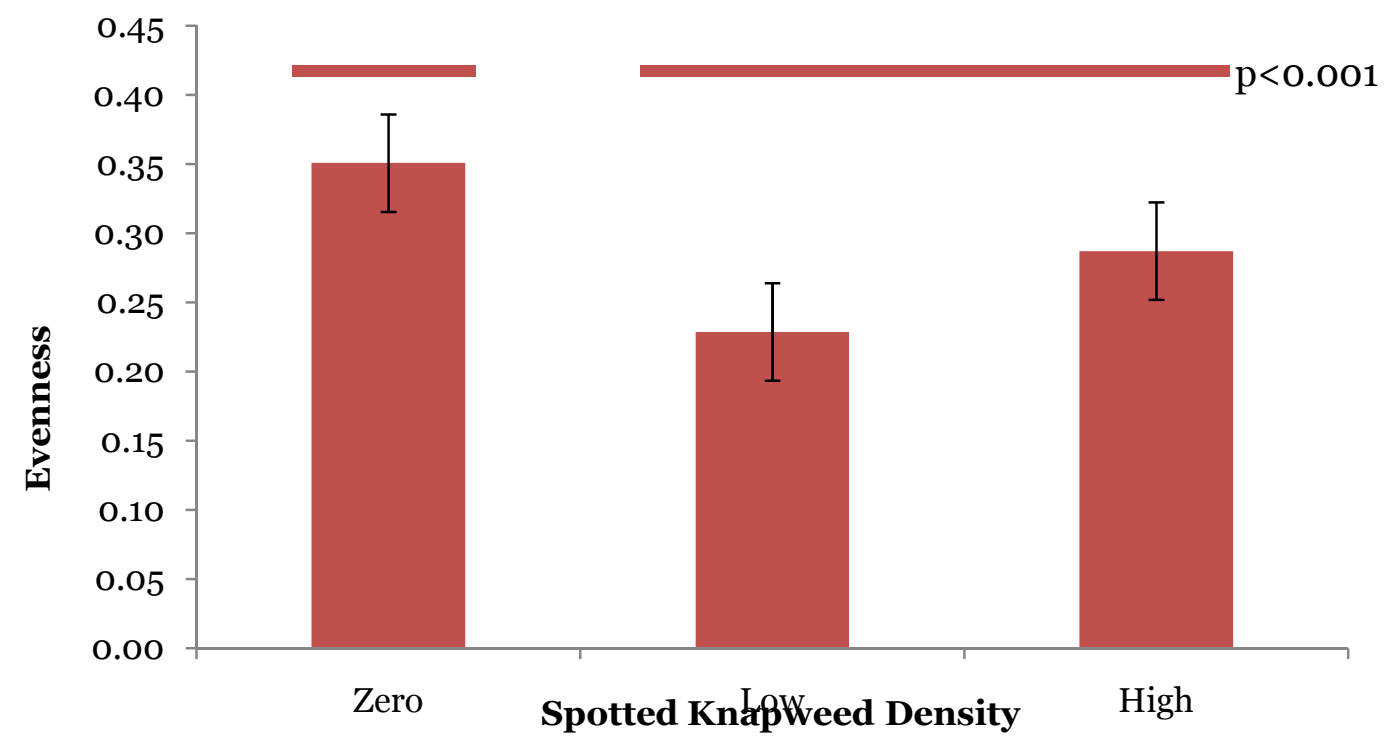

Figure 4.13. Evenness of number of individuals for each abundance level in areas with varying densities of spotted knapweed in the Grand Sable Dunes of Pictured Rocks National Lakeshore in Upper Michigan, USA. Horizontal lines above the bars show difference between areas with and without spotted knapweed abundance. The associated p-value is also shown. 


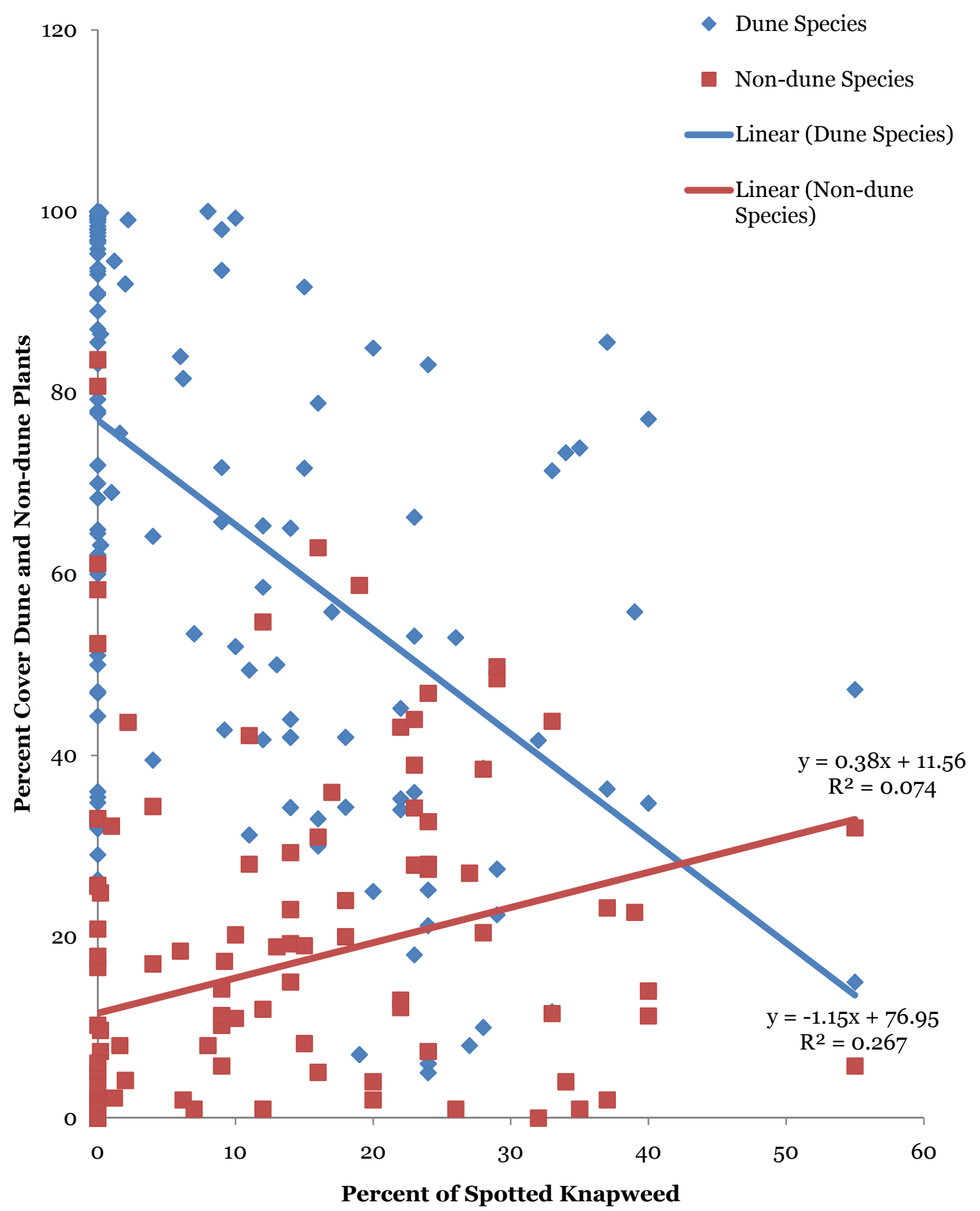

Figure 4.14. Linear regression of percent cover of dune $\left(\mathrm{r}^{2}=0.267, \mathrm{p}<0.001, \mathrm{df}=1,134\right)$ and non-dune $\left(\mathrm{r}^{2}=0.074, \mathrm{p}<0.001, \mathrm{df}=1,134\right)$ species related to percent cover of spotted knapweed in the Grand Sable Dunes of Pictured Rocks National Lakeshore in Alger County, Michigan. 


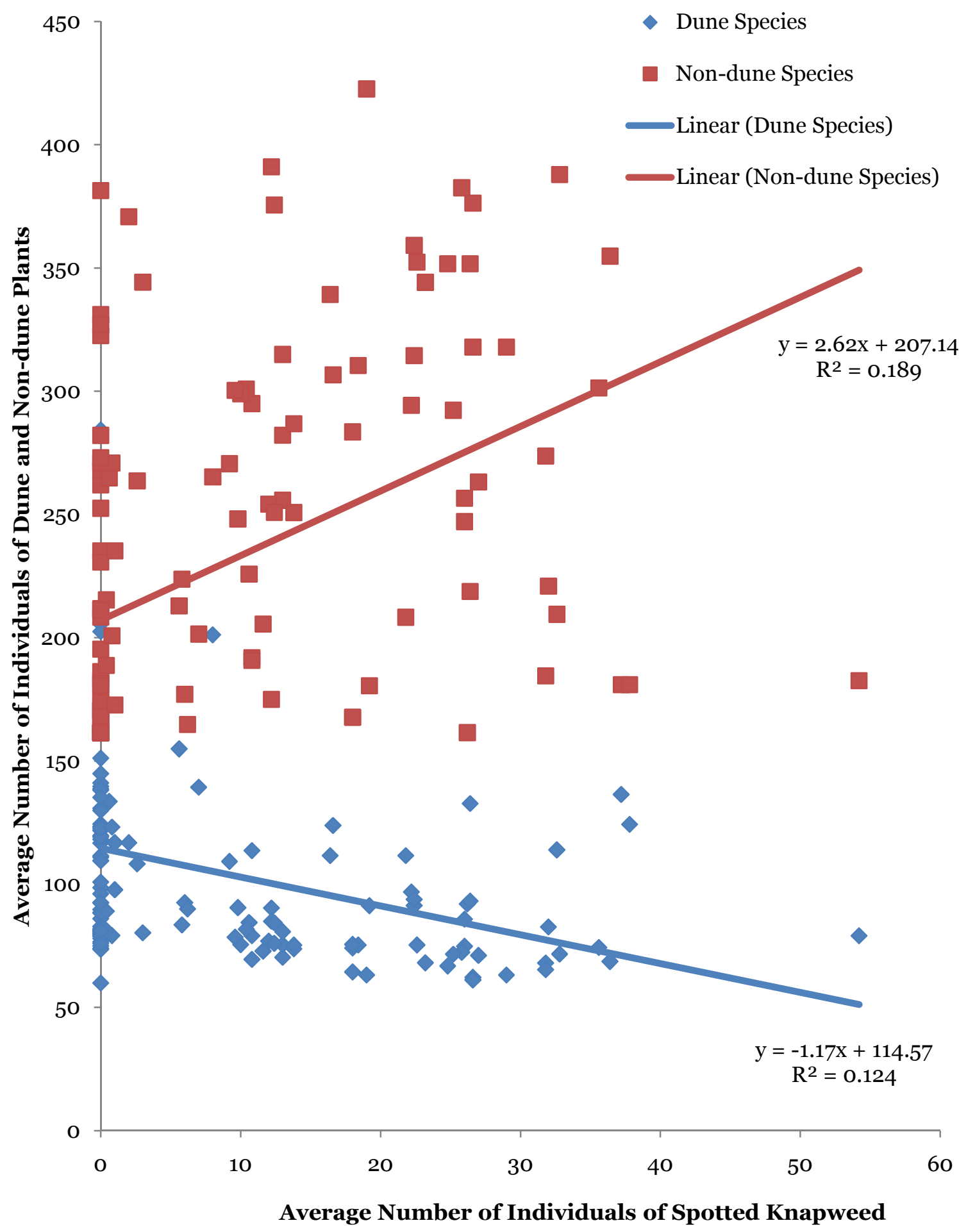

Figure 4.15. Linear regression of number of individual dune $\left(\mathrm{r}^{2}=0.124, \mathrm{p}<0.001, \mathrm{df}=1\right.$, $134)$ and non-dune $\left(\mathrm{r}^{2}=0.1885, \mathrm{p}<0.001, \mathrm{df}=1,134\right)$ plants related to the number of individual stems of spotted knapweed $\left(\mathrm{r}^{2}=.189, \mathrm{p}=0.000, \mathrm{df}=1,134\right)$ in the Grand Sable Dunes of Pictured Rocks National Lakeshore in Alger County, Michigan. 


\title{
CHAPTER 5
}

\section{EFFECTS OF HERBICIDE APPLICATION \\ TO SPOTTED KNAPWEED (Centaurea maculosa Lam.) ON NATIVE DUNE PLANT COMMUNITIES IN PICTURED ROCKS NATIONAL LAKESHORE, ALGER COUNTY, MICHIGAN}

\begin{abstract}
Spotted knapweed (Centaurea maculosa) has invaded over 120 hectares of the Grand Sable Dunes of Pictured Rocks National Lakeshore in the Upper Peninsula of Michigan. The natural succession of the dynamic dune ecosystem can be disrupted by invading plants, and the invading spotted knapweed population has therefore been targeted by the park for herbicide control. In this unique dune ecosystem, knowledge of herbicide efficacy and non-target effects is valuable due to a small number of studies exploring this type of ecosystem. This study assessed the effectiveness of Milestone $\mathbb{R}$ and Transline $®$ herbicides on spotted knapweed in the dune system and also assessed effects on non-target species. Species diversity was consistently significantly lower in herbicide treatment areas than in control areas. Herbicide application had varying effects on species richness and evenness. Herbicide application had a significant positive effect on native dune graminoids and a significant negative effect on dune stitchwort, and beach pea over three years as well as on non-native hawkweed and red sorrel. No significant differences between herbicide effectiveness were found. Herbicide selection should therefore be carefully considered based on generally accepted ecological soundness of the herbicides.
\end{abstract}




\section{Introduction}

Pictured Rocks National Lakeshore is one of four National Lakeshores protected by the National Park Services in the United States. It is located in the Upper Peninsula of Michigan on the south shoreline of Lake Superior (Figure 5.1). Its placement protects unique ecosystems of sandstone cliffs and areas of active lacustrine sand dunes. One of the park's most pressing management concerns is controlling the large assortment of invasive plants introduced to the park.

The Grand Sable Dunes of Pictured Rocks National Lakeshore consist of approximately 910 hectares of unique sand dune habitat. Sand dunes often have rare plants or habitats that occur in no other dune chains. Approximately 740 hectares of the Grand Sable Dunes is reserved as a Research Natural Area. This area is designated for research into the conservation of the unique active dune system and permanent research sites can be established and will be generally undisturbed (PIRO 2007). Not only are the Grand Sable Dunes the only active lacustrine sand dunes on Lake Superior, but they are also the only location that Pitcher's thistle (Cirsium pitcheri Torr. and A. Gray), a federally endangered plant, is found in some abundance on Lake Superior. The state threatened Lake Huron tansy (Tanacetum huronense Nutt.) is also found in these dunes.

Active sand dunes are considered such due to shifting sand, which continually changes the ecosystem. Native dune plant communities have adapted to this environment by using wind-driven seed dispersion methods and germination methods that do not require much organic matter or water (Maun 1994). The resulting open, sparse plant communities are therefore strongly affected by shifting sands. Stabilization of the dunes can disrupt the natural disturbance cycle, providing opportunities for nonnative plants to invade. 
The successional stage of an ecosystem can be determined by observing the vegetation that is present (Radosevich et al. 2007). As dune succession progresses, species richness and plant sizes generally increase, while evenness is high during early stages of succession when resources are abundant and lower during later successional stages (Radosevich et al. 2007). Early successional dunes are characterized by lower species richness and small plants that are adapted to frequent sand migration (Bach 1978). Mid-successional dunes are characterized by native dune plants mixed with a few shrubby plants such as juniper while late successional dunes include higher proportions of woody trees and shrubs (Bach 1978).

Sand dunes stabilize naturally as a result of native plant succession, but invading plants can change the disturbance pattern so that native plants that are adapted to the movement of sand in highly dynamic portions of the dunes are excluded from the system (Garcia-Mora et al. 2000). Exotic species introductions can alter many ecological processes and dune succession is no exception (Walker and Vitousek 1991; Leege and Murphy 2001). Dune systems are especially vulnerable to exotic species invasion because of limited competition by native plants due to low amounts of plant cover and frequent, high-intensity disturbances. In other systems, higher levels of native biodiversity may exclude exotic species invasion, but dynamic systems like sand dunes, which repeatedly return to early successional stages, tend to have inherently lower diversity levels (GarciaMora et al. 2000).

In 2003, it was estimated that approximately 30 hectares of the Grand Sable Dunes near the northeastern end of Grand Sable Lake were invaded by spotted knapweed (Marshall et al. 2003). In 2009, the invasion had spread to approximately 80 hectares (Figure 5.2). In seven years, the population had spread to more than double in size. The park has done more extensive mapping of invasive plants in the dunes and an 
estimated 150 hectares of the Grand Sable Dunes are currently invaded by exotic plants (Pictured Rocks National Lakeshore unpublished data).

The most difficult invaders to quantify and verify are those that affect ecosystem processes such as disturbance regimes (Vitouselk and Walker 1989; Mack and D’Antonio 1998). The impacts of invasion are often impossible to quantify due to lack of data on the species composition, structure, and function of ecosystems before they are invaded (National Research Council 2002). Impacts of invasive plants can be severe in a given ecosystem. The simplest approach to controlling weeds is to reduce abundance, but this solution is often inadequate for eradication (Radosevich et al. 2007). Land managers have therefore been searching for economically viable and environmentally friendly control methods for decades (Sheley et al. 1999).

Spotted knapweed (Centaurea maculosa Lam.) is an invasive species introduced to North America from eastern Europe in the early 1900s (Lym and Zollinger 1992). As an invasive, it reduces or displaces native plant species (USDA 2011). Spotted knapweed is well-adapted to overtake the dry and open disturbed habitats such as those that make up the Grand Sable Dunes. An extensive survey of plants at Pictured Rocks National Lakeshore was conducted in 1973, at which time spotted knapweed had not invaded the Grand Sable Dunes but was limited to roadsides within the park (Read 1975). A plant community survey in 1975 recorded spotted knapweed as a component in the dune system, but not at high population numbers (Bach 1978).

Not only can a single spotted knapweed plant produce more than 1000 seeds per season, but those seeds are viable for more than 5 years (Davis et al. 1993). This can often cause a re-infestation after eradication. Spotted knapweed also releases allelopathic compounds into the soil so that competing native plants have less chance of 
reestablishing themselves. These compounds, catechin (a natural phenol antioxidant secondary metabolite that acts as a herbicide) and cnicin (a sesquiterpene lactone that is generally toxic to plants) inhibit competition by a wide range of other plant species by inhibiting seed growth as well as inducing cell death due to acidification of the cytoplasm (Ridenour and Callaway 2001; Bais et al. 2003). However, the importance of the role of allelopathy in determining spotted knapweed dominance in an ecosystem is widely debated (Blair et al. 2006).

Currently, the park manages spotted knapweed by containing the larger populations and mechanically controlling the smaller invasions. Park personnel currently focus efforts along trails and roads to minimize spread. However, in the highly invaded dune environment, chemical control is the only feasible option (NPCA 2007). Herbicides are a viable option for control of invasive plants when other methods are not practical or cost effective (Holt 2009). The risks of herbicide application include effects on non-target species, residual chemicals in the soil, toxicity to non-target organisms, and concerns for human health (Holt 2009). Herbicides can be used to effectively reduce weed density and effects are generally rapid (Radosevich et al. 2007). A common trend in areas sprayed repeatedly with herbicides is the increase of herbicide-tolerant plants (Radosevich et al. 2007), so caution is needed when repeatedly using herbicides as a control method.

National Parks are approved to use only certain herbicides to control populations of invasive plants. Two of the herbicides approved for use on spotted knapweed are Milestone $\AA$ and Transline $®$. Pictured Rocks National Lakeshore does not have the resources to hand-pull the population of spotted knapweed in the Grand Sable Dunes and there is therefore a need to evaluate the use of herbicides in this system. 
The two park-approved herbicides, Milestone ${ }^{\circledR}$ and Transline $($, were tested in a small-scale, three-year study to determine which herbicide would most closely fit the park's management needs. The Milestone $®$ herbicide used in this study is manufactured by The Dow Chemical Company. The target plant group is broadleaf weeds. The active ingredient in Milestone $®$ is aminopyralid (Dow 2011a), a carboxylic herbicide. Milestone $\AA$ is therefore listed as a low volatility herbicide and is advertised as being rainfast in 2 hours (Dow 2011a). However, it is reported to have high soil mobility (Sharma and Singh 2001). Milestone ${ }^{\circledR}$ is not federally restricted and was listed on the Environmental Protection Agency's Reduced Risk Pesticide list in 2005 (Environmental Protection Agency 2011). That list includes compounds that have demonstrated lower risk to humans and the environment than other available alternatives.

The active ingredient in Dow's Transline $₫$ is clopyralid, which is an acrylic acid herbicide (Dow 2011b). The target plant group is broadleaf weeds (Dow 2011b) and the residue does not leach more than $25 \mathrm{~cm}$ into the soil and does not last past one year (Rice et al. 1997). It is also listed as a low-toxicity herbicide, but is not on the Reduced Risk Pesticide List (Environmental Protection Agency 2011). From this information, we hypothesized that both herbicides would reduce the spotted knapweed population, but expected Transline $\AA$ would be more effective than Milestone $\AA$ due to Milestone $₫$ being included on the Reduced Risk Pesticide list and generally more accepted as more environmentally friendly herbicide. We also hypothesized that Transline ${ }^{\circledR}$ would kill more non-target species than Milestone ${ }^{\circledR}$.

The objective of this study was to determine which of these herbicides is more effective at controlling spotted knapweed while having the least effect on rare native dune plants in the Grand Sable Dunes. Both herbicides are considered amino acid 
inhibitors, meaning that the herbicide attaches to vegetation, kills it, and is reportedly out of the system within a short time.

This study was designed to supply the park with baseline data to justify treating large areas of spotted knapweed in the dunes as well as observe any differences in richness and diversity between areas with differences in spotted knapweed abundance.

\section{Methods}

The study site was located in the Grand Sable Dunes of Pictured Rocks National Lakeshore in the Upper Peninsula of Michigan (Figure 5.1). The area of invasion was delineated in 2008 and contained 80 hectares of dunes invaded by spotted knapweed (Figure 5.2).

Study blocks were established in the summer of 2008 and herbicide application occurred on July 16 and 17 in 2008, July 8 in 2009, and July 12 in 2010. Vegetation in the blocks was quantified prior to herbicide application and then quantified again 7 days after the herbicide application to assess immediate mortality. Herbicides were applied each year when the plants were at the same developmental stage of breaking flower buds. The park provided the herbicides Milestone $\AA$ and Transline $\AA$ as well as the personnel to apply the herbicides following National Park Service spot-spray application guidelines. Spot-spraying involves keeping the spray wand tip as close to the plant while trying to spray as much of the vegetative growth on the targeted plant as possible (Grzesiak 2010). Application rates and methods on the herbicide labels were also followed.

\section{Field Methods}

Six blocks, 33 meters by 19 meters and each containing 15 treatment areas, were established in the Grand Sable Dunes (Figure 5.3). The four corners of each of the 6 
blocks were marked with rebar with tags noting "MTU/NPS.” The blocks were permanently marked in this manner so that monitoring surveys could be conducted in the future. The six blocks consisted of 3 treatments with 5 replicates laid out in an area extensively invaded by spotted knapweed in a 3 by 5 grid (Figure 5.4). The three treatments were a control, spot application of Milestone $₫$, and spot application of Transline®. Each treatment area was separated by 2 meter buffers (Figure 5.4).

Within each treatment area, five $1 \mathrm{~m}$ by $1 \mathrm{~m}$ quadrats of vegetation were assessed ( $n=150$ for each treatment). Percent cover was recorded in $5 \%$ cover classes based on ocular measurements and number of individuals were recorded by counting individual plants. Any species measuring less than $5 \%$ was recorded as $1 \%$. Any plants rooted within the quadrat were recorded as an individual. Any part of a plant occurring inside the quadrat was included in the percent cover measurement.

\section{Statistical Methods}

Species richness, Shannon-Wiener diversity, and species evenness were calculated for each treatment area. Mean percent cover and mean number of individuals per species was calculated for each species or species group. Species richness represents the number of species present within each treatment area. Shannon-Wiener diversity was calculated using the equation:

$$
\mathrm{H}=-\sum p_{i} \ln p_{i} \quad \text { (Equation 5.1) }
$$

Where $p_{i}=$ percent cover per species (Hayek and Buzas 1997). Species evenness was calculated with the equation:

$$
\mathrm{E}=\mathrm{H} / \ln (\mathrm{S}) \quad \text { (Equation 5.2) }
$$

Where $\mathrm{H}=$ Shannon-Wiener diversity and $\mathrm{S}=$ species richness (Hayek and Buzas 1997). 
An arcsine transformation was used for percent cover data. A log transformation was used for the number of graminoids and spotted knapweed data due to some of the subplots having very high graminoid and spotted knapweed numbers which resulted in the presence of an exponential relationship between the means and variances for these data. A square root transformation was used on the number of individuals of other species due to the high occurrence of zeros in the dataset which resulted in the presence of a linear relationship between the means and variances for these data. The data transformations enabled the assumption of homogeneity of variance to be met for subsequent analysis.

All analyses were performed using Statistix 8 (Statistix 2003). Randomized complete block ANOVA was used to test differences in percent cover and number of individuals of each species and the richness, diversity, and evenness summary data among the three treatments (Statistix 2003). The dependent variable in the analysis was the species or summary statistic, the block factor was the block, and the treatment factor was the three treatments. Two user-defined contrasts were performed after each ANOVA. The first contrast compared control areas with areas to which herbicides were applied. The second contrast tested areas sprayed with Milestone® with areas sprayed with Transline $®$.

\section{Results}

A total of 25 species were found in the herbicide study plots (Table 5.1). Differences in percent cover richness or number of individuals richness, diversity, and evenness between treatment areas were not significant at the pre-spray 2008 sampling period, indicating that the areas chosen for the 6 study plots were generally homogenous. 
Across all time periods, summary statistics, and species, differences in the contrast between the herbicides were not significant. Due to none of the p-values for the second contrast being less than or equal to o.1, our reporting will focus on the contrast between control and herbicide treatments.

\section{Summary Statistics}

Richness: Species richness was different between the control and herbicide treatments for both the pre- and post-treatment sampling in $2009(\mathrm{~F}=5.24, ; \mathrm{df}=1,88$, $\mathrm{p}=0.007 ; \mathrm{F}=6.9, \mathrm{df}=1,88 ; \mathrm{p}=0.002)$, but only different during the post-treatment sampling in $2010(\mathrm{~F}=5.56, \mathrm{df}=1,88, \mathrm{p}=0.006)$ (Figure 5.5).

Diversity: Diversity in terms of percent cover was different between the control and herbicide treatments across all time periods following the first 2008 herbicide treatments $(\mathrm{p}<0.001)$. Diversity in terms of number of individuals was different $(\mathrm{p}<0.001)$ in 2009 and 2010 between the controls and herbicide treatments (Figure 5.6 and 5.7).

Evenness: Species evenness of percent cover was different between the control and herbicide treatments for both the post-treatment $2008(\mathrm{~F}=41.81, \mathrm{df}=1,88, \mathrm{p}<0.001)$ and pre-treatment $2010(\mathrm{~F}=\mathbf{2 . 2 2}, \mathrm{df}=1,88, \mathrm{p}=0.048)$ sampling periods (Figure 5.8). Evenness of number of individuals was different in pre- and post-treatment sampling periods in $2009(\mathrm{~F}=6.9,4.58, \mathrm{df}=1,88, \mathrm{p}=0.004,0.020)$, as well as both sampling periods of $2010(\mathrm{~F}=6.12,5.97, \mathrm{df}=1,88, \mathrm{p}=0.005,0.004)$ (Figure 5.9).

\section{Effects on Individual Plant Species}

The tables summarizing each sampling period are the averages of each species in each treatment within each time period. $\mathrm{P}$-values are shown for the two user-defined 
contrasts performed. Missing results represented by " $\mathrm{M}$ ” could not be analyzed due to the sum of squares being too small. The first contrast performed compared the control against the herbicide treatments. The second contrast performed compared the herbicide Milestone $\AA$ with the herbicide Transline $®$. Again, no differences were found to be significant in the contrast between the two herbicides. However, differences were significant beginning in the pre-spray sampling period of 2009.

Pre-spray 2008: Differences in mean percent cover and mean number of individuals for each species were not significant between controls and herbicide treatments (Tables 5.2 and 5.3).

Post-spray 2008: Percent cover $(\mathrm{F}=111.67, \mathrm{df}=1,88, \mathrm{p}<0.001)$ and number of individuals $(\mathrm{F}=101.76, \mathrm{df}=1,88, \mathrm{p}<0.001)$ of spotted knapweed were significantly greater in the controls compared to the herbicide treatments following treatment in 2008 (Tables 5.4 and 5.5).

Pre-spray 2009: Percent cover $(\mathrm{F}=21.08, \mathrm{df}=1,88, \mathrm{p}<0.001)$ and number of individuals $(\mathrm{F}=14.33, \mathrm{df}=1,88, \mathrm{p}<0.001)$ of spotted knapweed was significantly greater in the controls compared to the herbicide treatment areas preceding treatment in 2009 (Tables 5.6 and 5.7). Percent cover of dune stitchwort was also significantly greater in the control areas compared to the treated areas $(\mathrm{F}=16.13, \mathrm{df}=1,88, \mathrm{p}<0.001)$ ) (Table 5.6). Percent cover $(\mathrm{F}=12.97, \mathrm{df}=1,88, \mathrm{p}<0.001)$ of graminoids were significantly less in control treatments compared to the herbicide treatments (Table 5.7).

Post-spray 2009: Percent cover $(\mathrm{F}=25.9, \mathrm{df}=1,88, \mathrm{p}<0.001)$ and number of individuals $(\mathrm{F}=24.32, \mathrm{df}=1,88, \mathrm{p}<0.001)$ of spotted knapweed were significantly greater in control areas compared to the herbicide treatment areas post-treatment sampling in 2009 (Table 5.8 and 5.9). Hawkweed percent cover $(\mathrm{F}=14.83, \mathrm{df}=1,88, \mathrm{p}<0.001)$ and 
number of individuals $(\mathrm{F}=14.93, \mathrm{df}=1,88, \mathrm{p}<0.001)$ were also significantly greater during this time period (Table 5.8 and 5.9). Percent cover of graminoids $(\mathrm{F}=11.54, \mathrm{df}=1,88$, $\mathrm{p}<0.001)$ was significantly less in control areas compared to the herbicide treatment areas (Table 5.8).

Pre-spray 2010: Percent cover $(\mathrm{F}=9.56, \mathrm{df}=1,88, \mathrm{p}<0.001)$ and number of individuals $(\mathrm{F}=10.34, \mathrm{df}=1,88, \mathrm{p}=0.004)$ of spotted knapweed were significantly greater in control areas compared to the treated areas during the pre-treatment sampling in 2010 (Tables 5.10 and 5.11). Percent cover and number of individuals of hawkweed $(\mathrm{F}=4.77, \mathrm{df}=1,88, \mathrm{p}=0.017 ; \mathrm{F}=3.84, \mathrm{df}=1,88, \mathrm{p}=0.034)$ and beach pea $(\mathrm{F}=4.0, \mathrm{df}=1,88$, $\mathrm{p}=0.022 ; \mathrm{F}=3.44, \mathrm{df}=1,88, \mathrm{p}=0.037$ ) were also significantly greater in control areas compared to herbicide treatment areas (Tables 5.10 and 5.11). Percent cover and number of individuals of graminoids $(\mathrm{F}=10.57, \mathrm{df}=1,88, \mathrm{p}<0.001 ; \mathrm{F}=3.87, \mathrm{df}=1,88, \mathrm{p}=0.009)$ and red sorrel $(\mathrm{F}=3.45, \mathrm{df}=1,88, \mathrm{p}=0.040 ; \mathrm{F}=4.17, \mathrm{df}=1,88, \mathrm{p}=0.019)$ were significantly less in control areas compared to the treatment areas (Tables 5.10 and 5.11).

Post-spray 2010: Percent cover $(\mathrm{F}=92.48, \mathrm{df}=1,88, \mathrm{p}<0.001)$ and number of individuals $(\mathrm{F}=67.46, \mathrm{df}=1,88, \mathrm{p}<0.001)$ of spotted knapweed were significantly greater in control areas compared to the treated areas during the post-treatment sampling in 2010 (Tables 5.12 and 5.13). Percent cover and number of individuals of hawkweed $(\mathrm{F}=6.11, \mathrm{df}=1,88, \mathrm{p}=0.005 ; \mathrm{F}=5.3, \mathrm{df}=1,88, \mathrm{p}=0.014)$ and beach pea $(\mathrm{F}=4.16, \mathrm{df}=1,88$, $\mathrm{p}=0.018 ; \mathrm{F}=3.44, \mathrm{df}=1,88, \mathrm{p}=0.037$ ) were also significantly greater in control areas compared to herbicide treatment areas (Tables 5.12 and 5.13). Percent cover and number of individuals of graminoids $(\mathrm{F}=15.35, \mathrm{df}=1,88, \mathrm{p}<0.001 ; \mathrm{F}=4.19, \mathrm{df}=1,88, \mathrm{p}=0.012)$ and red sorrel $(\mathrm{F}=3.42, \mathrm{df}=1,88, \mathrm{p}=0.039 ; \mathrm{F}=3.6, \mathrm{df}=1,88, \mathrm{p}=0.035)$ were significantly less in control areas compared to the treatment areas (Tables 5.12 and 5.13). 


\section{Discussion}

The results of this study demonstrate that the herbicide treatments are effective at reducing spotted knapweed and hawkweed with no differences in the effectiveness of the two herbicides. Herbicide application seemed to have a positive effect on graminoid populations, which might be expected since graminoids do not fall into the target plant category of the herbicides. There were occasional yet inconsistent effects on other plants, including red sorrel and beach pea.

Species diversity decreased in 2009 in the herbicide treatments following the first year of herbicide application. There are no indications at this time that there was a significant recovery in diversity after 3 years. There is also no indication of recovery in species richness or evenness after 3 years of applying herbicide. This could change after continual application of herbicide ceases. There was a slight increase in species richness between 2009 and 2010, possibly due to less herbicide being applied to the study area. Studies of diffuse knapweed (Centaurea diffusa) control have shown that richness and diversity of native plant communities sometimes do not recover (Stephens et al. 2009), while other studies have shown a recovery in biodiversity over time (Rice et al. 1992; Rice et al. 1997; Sheley and Jacobs 1997; Sheley et al. 1998).

The percent cover and number of individuals of each species were not significantly different between treatment areas before treatments began, indicating that the areas chosen for different treatments were generally homogenous. Significant differences were only found in the contrast comparing control treatments with treatments to which herbicides had been applied, suggesting that neither herbicide was

more effective than the other or that one had a harsher effect on non-target species than the other. 
Since spotted knapweed was the target of the spot-sprayed herbicides, the results show that the herbicides were immediately effective following the first herbicide application and continued to be effective through the end of the study. Differences were also positively significant for graminoids and negatively significant for hawkweed. Hawkweed could fall into the herbicide target groups, so spray drift or residue could have affected those populations. Hawkweed is considered a nuisance non-native species in the dunes, so the park is not concerned with decreasing those population levels. Grasses and sedges are native dune plants and those populations increased in treated areas, so control of spotted knapweed seems to have a positive effect on those species. Dune stitchwort declined for one sampling period. Since this is a linear-leaved plant that is also considered a species of special concern in the state of Michigan; therefore, nontarget impacts on that species are of concern to the park.

In 2010, differences in beach pea and red sorrel were significant, as were differences in spotted knapweed, hawkweed, and graminoids as species showing significant differences between control areas and areas treated with herbicide. Red sorrel is considered a nuisance species by the park, but beach pea is a native dune plant. Dune stitchwort was not different between control and herbicide treatments in 2010 because the population had decreased across all treatments. The same species that were different after treatment in 2010 were different before the herbicide application that same year, indicating no immediate mortality. This could be due to the small amounts of herbicide needing to be applied during that treatment year.

Beach pea was significantly different between control and herbicide treatments only in 2010, so it is possible that sustained herbicide application could have a greater effect on native dune species. The herbicides should be applied carefully to only target 
species, since it seems that continued applications will increase the non-target effects, especially to broad-leaved species.

Interestingly, Lake Huron tansy was generally unaffected. This could be due to the diligence of park personnel adhering to protocols to protect native dune species. Moonworts, a genus that is of special concern to the state, also seem to be unaffected by herbicide application. However, dune stitchwort, a species of special concern in Michigan, did show differences between herbicide treatments and controls during some observation periods. This may be due to the plant's small stature and its tendency to grow alongside spotted knapweed plants.

The effects of a single invasive plant can be negligible; however, the aggregate effects of multiple invasive plants can be overwhelming in an ecosystem (National Research Council 2002). Therefore, the presence of not only spotted knapweed but also red sorrel, hawkweed, Deptford pink, red clover, and rockcress indicate a much more pressing problem than a single plant invading the dunes.

Due to gaps in park records, it has not been possible to determine whether invaded areas were more diverse prior to spotted knapweed invasion. Spotted knapweed, red sorrel, and hawkweed were confirmed in the dunes as early as $1975(\operatorname{Read} 1975$, Bach 1978). It is also not possible to determine whether spotted knapweed was the first invader. If spotted knapweed was in fact the primary invader, hawkweed and red sorrel may be invading by utilizing the optimal habitat that spotted knapweed is creating via rapid dune stabilization (Marshall et al. 2008). Other environmental factors may influence the distribution of exotic species. A separate study conducted in the Grand Sable Dunes noted the same increase in diversity in areas invaded by spotted knapweed 
(Marshall et al. 2003). That study also found that the second and third most commonly occurring plants in the Grand Sable Dunes were hawkweed and red sorrel.

The results of this study did not show a difference between the herbicides that were used. We hypothesized that Transline $®$ herbicide would be more detrimental to

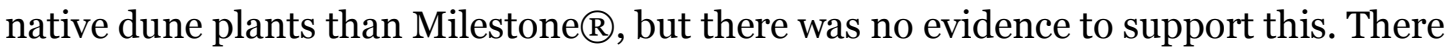
were no differences between the herbicide treatments in spotted knapweed mortality or non-target effects. The objective of this study (determining which herbicide was more effective at controlling spotted knapweed while having the least effect on native dune plants) was met by determining that neither herbicide was more effective than the other. Based on our results, we suggest that either herbicide is a viable candidate for the largescale management of spotted knapweed that the park is planning.

\section{Future Implications}

From our results, we suggest that spotted knapweed can be controlled without long-term harmful effects on native plant vegetation, but we would suggest that research continues through the time frame of seed viability and that strict spraying protocols are adhered to.

This herbicide study will be continued at least for the next 2 years. Some areas will cease to be sprayed to determine if 3 intensive spot-sprays will adequately control spotted knapweed or if spraying will need to continue for at least 5 years to control reestablishment due to the five-year seed viability.

As plans are developed to treat larger areas, systematic grids should be laid out over the treatment areas to enhance the precision, completeness and effectiveness of the applications. 


\section{Acknowledgements}

Bruce Leutscher of Pictured Rocks National Lakeshore provided valuable input, supplies, and herbicide teams during the course of this study. Joseph Latsch, Hannah Abbotts, Matt Abbotts, and Donavon Young provided field help. The 2008-2010 Pictured Rocks National Lakeshore Exotic Plant Management Teams led by Katherine Grzesiak provided the expertise and manpower needed to apply the herbicides. Finally, rare dune plant identification was aided by Adrienne Bozic.

\section{Literature Cited}

Bach, David P. 1978. Plant communities, habitats, and soil conditions of Grand Sable Dunes, Pictured Rocks National Lakeshore, Michigan. M.S. Thesis. Houghton, Michigan: Michigan Technological University. 180 p.

Bais, H.P., R. Vepachedu, S. Gilroy, R.M. Callaway, and J.M. Vivanco. 2003. Allelopathy and exotic plant invasion: from molecules and genes to species interactions. Science 301(5638): 1377-1380.

Blair, A.C., S.J. Nissen, G.R. Brunk, and R.A. Hufbauer. 2006. A lack of evidence for an ecological role of the putative allelochemical $( \pm)$-catechin in spotted knapweed invasion success. The Journal of Chemical Ecology 32: 2327-2331.

Davis, E.S., P.K. Fay, T.K. Chicoine, and C.A. Lacey. 1993. Persistence of spotted knapweed (Centaurea maculosa) seed in soil. Weed Science 41: 57-61.

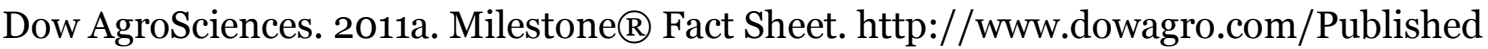
Literature/dh_o2b1/o901b803802b1ofc.pdf?filepath=range/pdfs/noreg/o1056950.pdf\&fromPage=GetDoc. Accessed: March 2011.

Dow AgroSciences. 2011b. Transline $®$ Fact Sheet. http://msdssearch.dow.com/ PublishedLiteratureDAS/dh_o6e1/o901b803806e1d8f.pdf?filepath=ivm/pdfs/n oreg/o10-50843.pdf\&fromPage=GetDoc. Accessed: March 2011.

Environmental Protection Agency. 2011. Pesticides: regulating pesticides. http://www.epa.gov/poordoo1/workplan/reducedrisk.html. Accessed: March 2011.

Garcia-Mora, M.R., J.B. Gallego-Fernandez, and F. Garcia-Novo. 2000. Plant diversity as a suitable tool for coastal dune vulnerability assessment. Journal for Coastal Research. 16: 990-995. 
Grzesiak, K. 2010. Pictured Rocks National Lakeshore Exotic Plant Management Team Handbook.

Hayek, L.C. and M.A. Buzas. 1997. Surveying natural populations. New York: Columbia University Press. 563 p.

Holt, J.S. 2009. Management of invasive terrestrial plants. Pp. 126-140 in M.N. Clout and P.A. Williams, eds. Invasive Species Management. Oxford: Oxford University Press.

Leege, L.M. and P.G. Murphy. 2001. Ecological effects of the non-native Pinus nigra on sand dune communities. Canadian Journal of Botany 79: 429-427.

Lym, R.G. and R.K. Zollinger. 1992. Spotted knapweed (Centaurea maculosa Lam.). NDSU Extension Service, North Dakota State University of Agriculture and Applied Science.

Mack, M.C. and C.M. D’Antonio. 1998. Impacts of biological invasions on disturbance regimes. Trends in Ecology and Evolution 13:195-198.

Marshall, J.M., A.J. Storer, and B. Leutscher. 2008. Comparative analysis of plant and ground dwelling arthropod communities in lacustrine dune areas with and without Centaurea biebersteinii (Asteraceae). The American Midland Naturalist 159(2): 261-274.

Maun, M.A. 1994. Adaptations enhancing survival and establishment of seedlings on coastal dune systems. Plant Ecology 111(1): 59-70.

National Research Council. 2002. Predicting invasions of nonindigenous plants and plant pests. National Academy Press, Washing, DC.

Pimentel, D., L. Lach, R. Zuniga, and D. Morrison. 2000. Environmental and economic costs associated with non-indigenous species in the United States. Bioscience 50: $53-65$.

Radosevich, S.R., J.S. Holt, C.M. Ghersa. 2007. Ecology of Weeds and Invasive Plants. John Wiley \& Sons, Inc. Hoboken, New Jersey. 454 p.

Read, R.H. 1975. Vascular plants of Pictured Rocks National Lakeshore, Alger County, Michigan. The Michigan Botanist 14(1): 3-43.

Rice, P.M, D.J. Bedunah, and C.E. Carlson. 1992. Plant community diversity after herbicide control of spotted knapweed. U.S Department of Agriculture, Forest Service, Intermountain Forest 460: 1-6.

Rice, P.M., J.C. Toney, D.J. Bendunah, and C.E. Carlson. 1997. Plant community diversity and growth form responses to herbicide applications for control of Centaurea maculosa. Journal of Applied Ecology 34: 1397-1412. 
Ridenour, W.M. and R.M. Callway. 2001. The relative importance of allelopathy in interference: the effects of an invasive weed on a native bunchgrass. Oecologia 126(3): 444-450.

Sharma, S.D. and M. Singh. 2001. Susceptibility of Florida candler fine soil to herbicide leaching. Bulletin of Environmental Contamination and Toxicology 67: 594-60o.

Sheley, R.L. and J.S. Jacobs. 1997. "Acceptable” levels of spotted knapweed (Centaurea maculosa) control. Weed Technology 11: 363-368.

Sheley, R.L., J.S. Jacobs, M.F. Carpinelli. 1998. Distribution, biology, and management of diffuse knapweed (Centaurea diffusa) and spotted knapweed (Centaurea maculosa). Weed Technology 12: 353-362.

Sheley, R.L., J.S. Jacobs, M.F. Carpinelli. 1999. Spotted knapweed. Pp. 350-351 in R.L. Sheley, J.K. Petroff, eds. Biology and management of noxious rangeland weeds. Corvallis: Oregon State University.

Statistix. 2003. Statistix® 8 Analytical Software. User's Manual. Tallahassee, p. 396.

Stephens, A.E.A., P.G. Krannitz, and J.H. Myers. 2009. Plant community changes after the reduction of an invasive rangeland weed, diffuse knapweed, Centaurea diffusa. Biological Control 51(1): 140-146.

United States Department of Agriculture. 2011. The PLANTS Database National Plant Data Center, Baton Rouge, LA, USA. http://plants.usda.gov. Accessed: March 19, 2011.

Vitousek, P.M. and L.R. Walker. 1989. Biological invasions by Myrica faya in Hawaii: plants population biology and ecosystem studies. Oikos 57: 7-13.

Walker, L.R. and P.M.Vitousek. 1991. An invader alters germination and growth of a native dominant tree in Hawaii. Ecology 72: 1449-1455. 


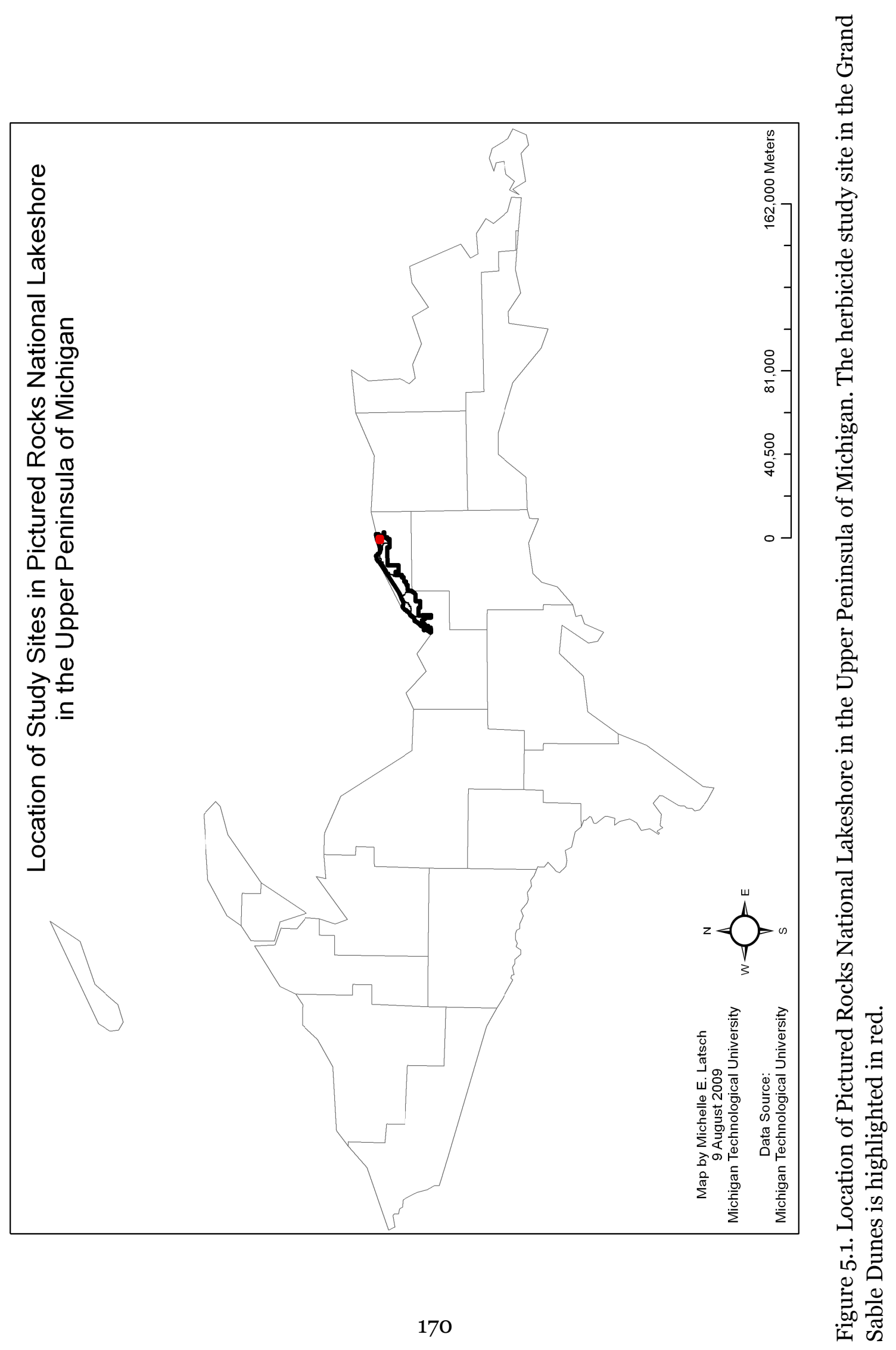




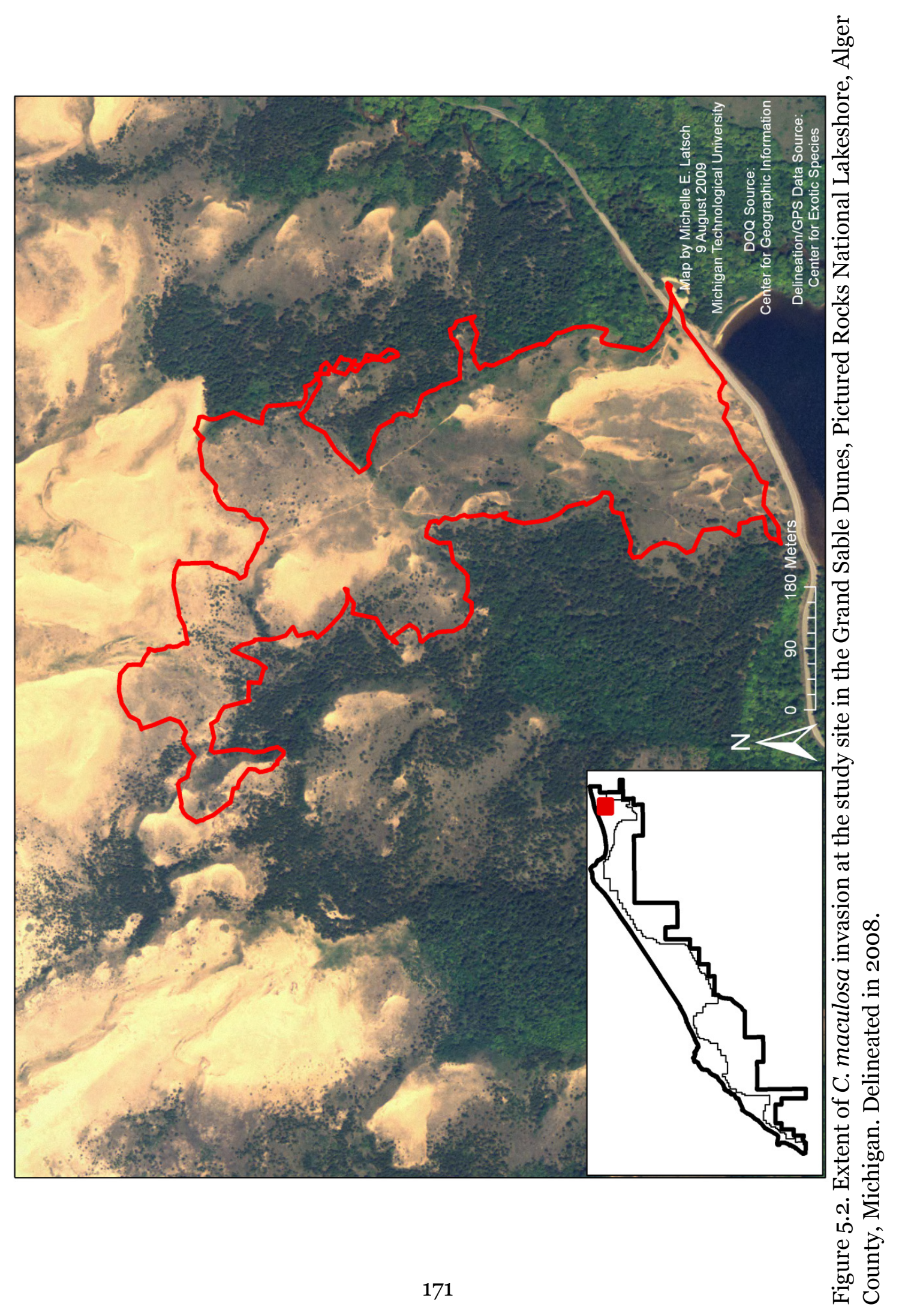




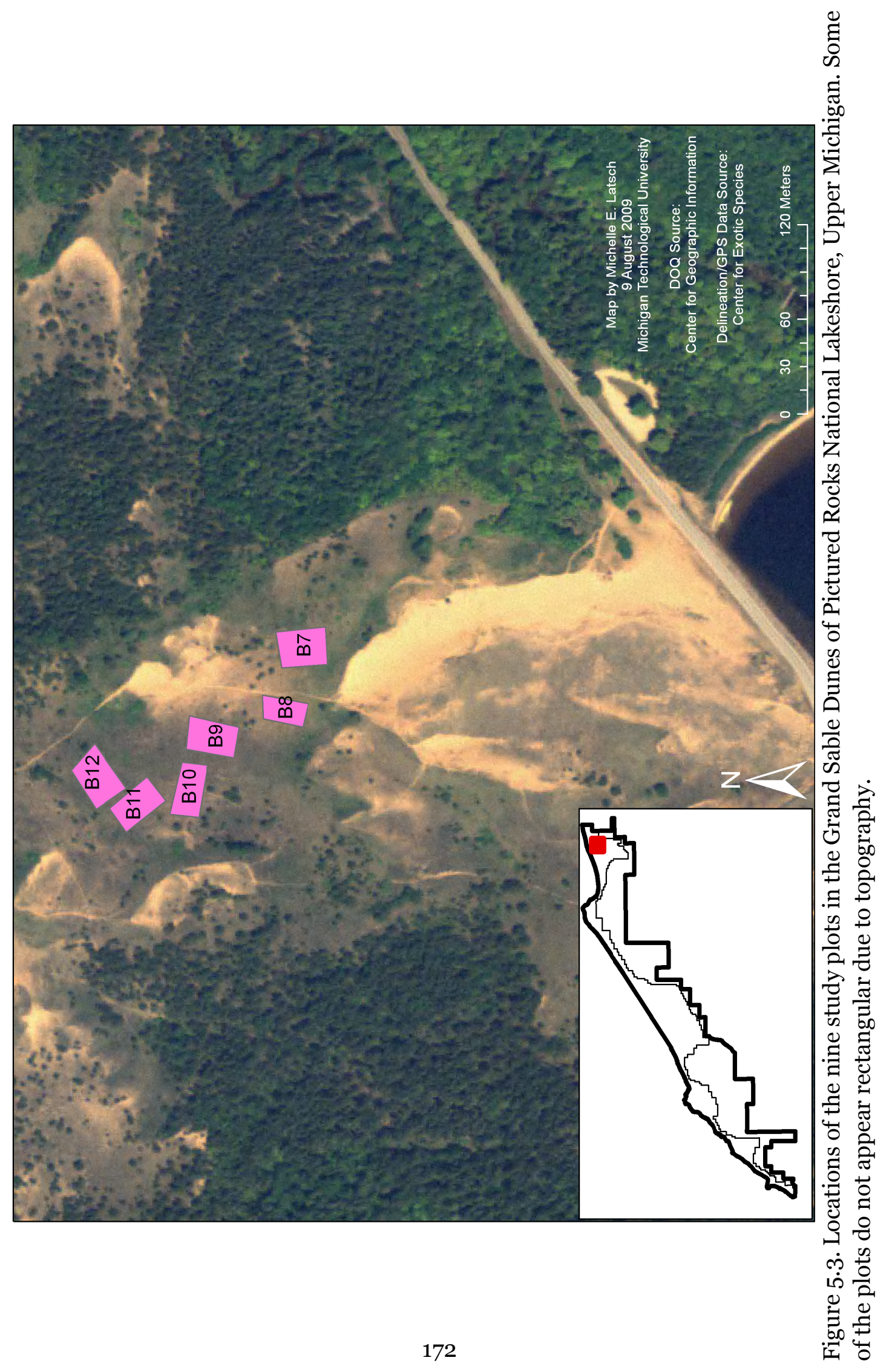




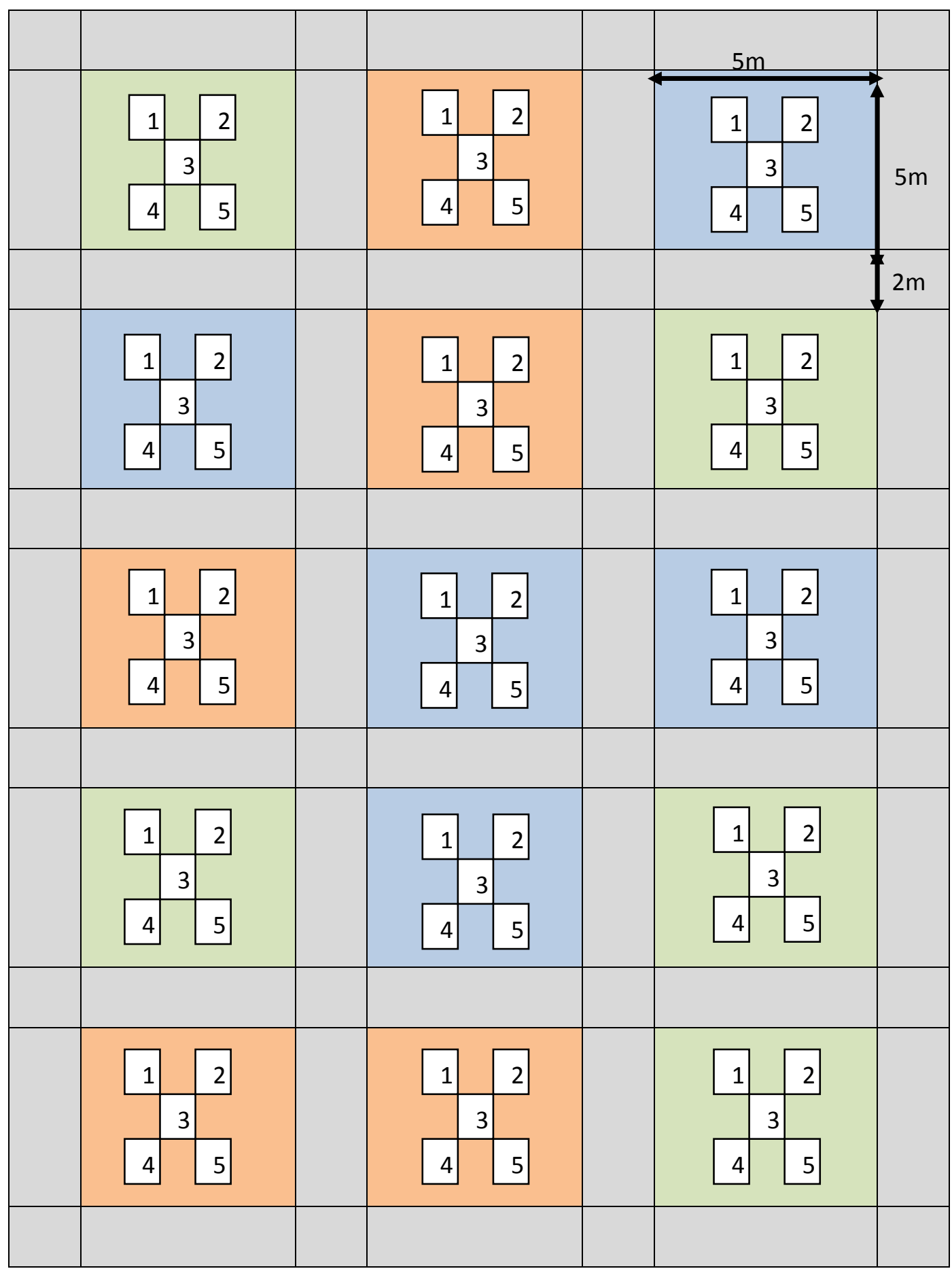

Figure 5.4. Three by five grid layout of a single sampling block for the herbicide study in the Grand Sable Dunes of Pictured Rocks National Lakeshore, Michigan. Gray areas indicate 2 meter buffer areas between treatment areas and around plots. Numbered squares are the layout of the sampling quadrats within each subplot. Each color indicates a different treatment (e.g. blue may represent controls, orange may represent Milestone $\AA$, and green may represent Transline () . 
Table 5.1. Species quantified in the herbicide blocks in Pictured Rocks National Lakeshore, Alger County, Michigan. Status indicates " $T$ ” for state threatened species, "SC" for species of special concern, or "I" for invasive non-native plants.

\begin{tabular}{llc}
\hline Scientific Name & Species & Status \\
\hline Achillea millefolium L. & Yarrow & \\
Arabis lyrata L. & Rockcress & I \\
Asclepias syriaca L. & Milkweed & \\
Botrychium spp. Sw. & Moonwort & SC \\
Centaurea maculosa Lam. & Spotted knapweed & I \\
Dianthus armeria L. & Deptford pink & I \\
Equisetum arvense L. & Horsetail & \\
Fragaria vesca L. & Wild strawberry & \\
Hieracium spp. L. & Hawkweed & I \\
Juniperus communis L. & Juniper & \\
Lathyrus japonicas Willd. & Beach pea & \\
Leucanthemum vulgare Lam. & Ox-eye daisy & \\
Lithospermum caroliniense Walter & Hairy puccoon & \\
Maianthemum stellatum L. & Starry false Solomon's seal & \\
Oenothera parviflora L. & Evening primrose & \\
Plantago major L. & Plantain & T \\
Poaceae and Cyperaceae & Graminoid & \\
Prunus pumila L. & Dune cherry & \\
Rosa blanda Aiton & Smooth rose & \\
Rumex acetosella L. & Red sorrel & \\
Solidago spp. L. & Goldenrod & \\
Stellaria longipes Goldie & Dune stitchwort & \\
Tanacetum huronense Nutt. & Lake Huron tansy & \\
Toxicodendron radicans L. Kuntze & Poison ivy & \\
Trifolium pretense L. & Red clover & \\
\hline & & \\
& &
\end{tabular}




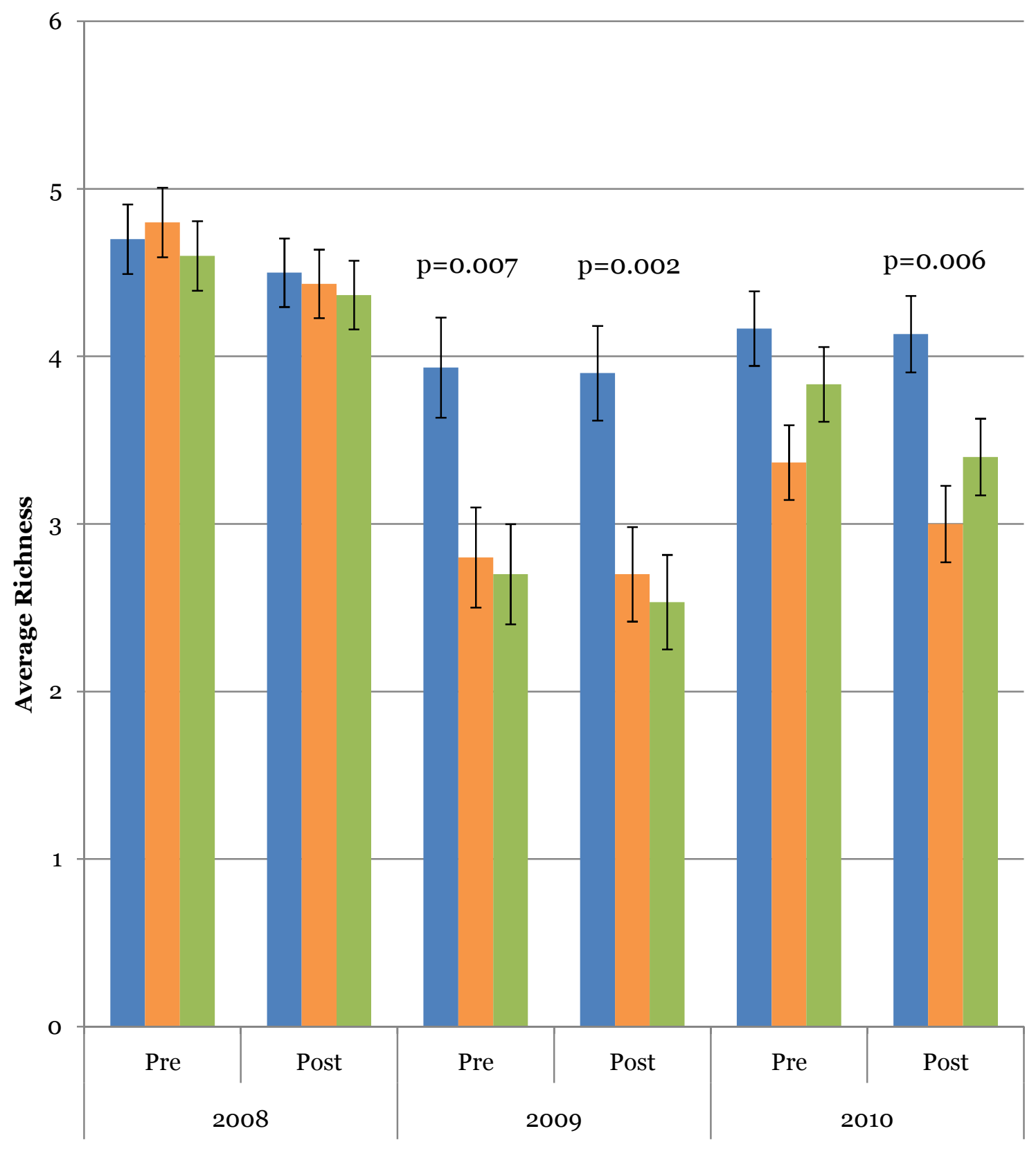

Time

- Control $\square$ Milestone $\square$ Transline

Figure 5.5. Average species richness for each treatment in all six time periods of the herbicide study at Pictured Rocks National Lakeshore, Alger County, Michigan. P-values are shown for the significant differences in the contrast between the control treatment and the two herbicide treatments $(\mathrm{df}=1,88)$. 


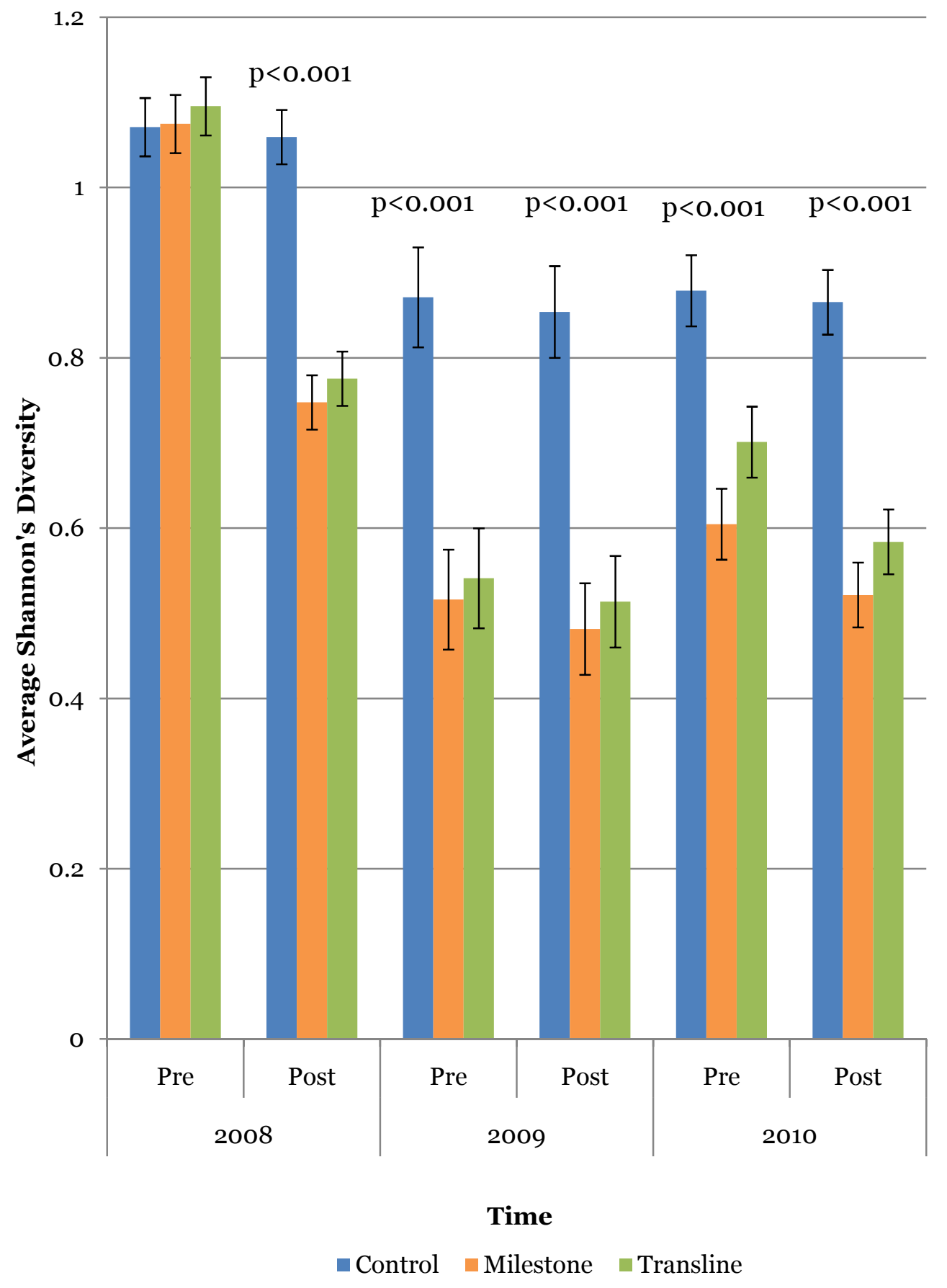

Figure 5.6. Diversity based on percent cover for each treatment in all six time periods of the herbicide study at Pictured Rocks National Lakeshore, Alger County, Michigan. Pvalues are shown for the significant differences in the contrast between the control treatment and the two herbicide treatments $(\mathrm{df}=1,88)$. 


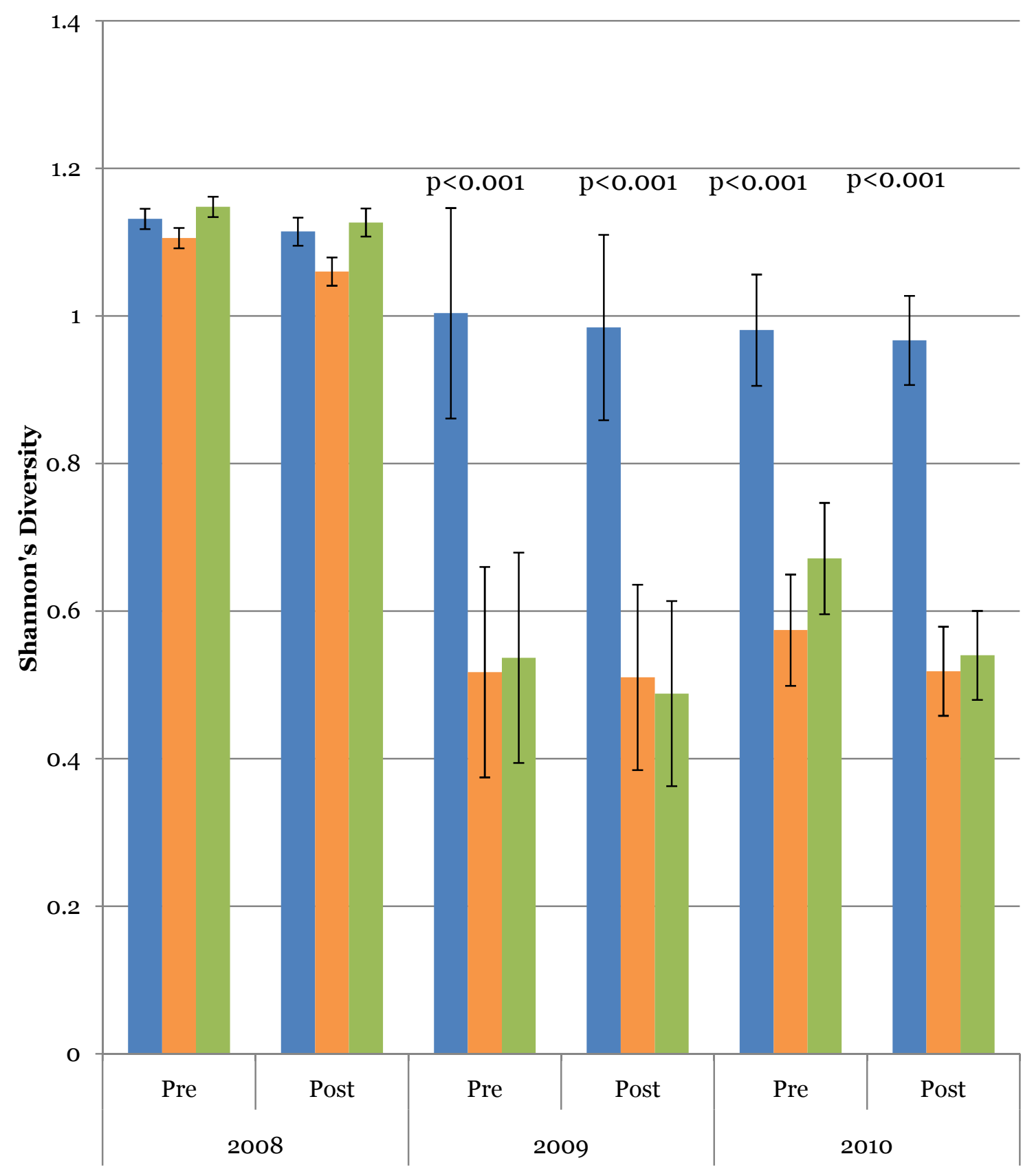

Time

- Control $\square$ Milestone $\square$ Transline

Figure 5.7. Diversity based on number of individuals for each each treatment in all six time periods of the herbicide study at Pictured Rocks National Lakeshore, Alger County, Michigan. P-values are shown for the significant differences in the contrast between the control treatment and the two herbicide treatments $(\mathrm{df}=1,88)$. 


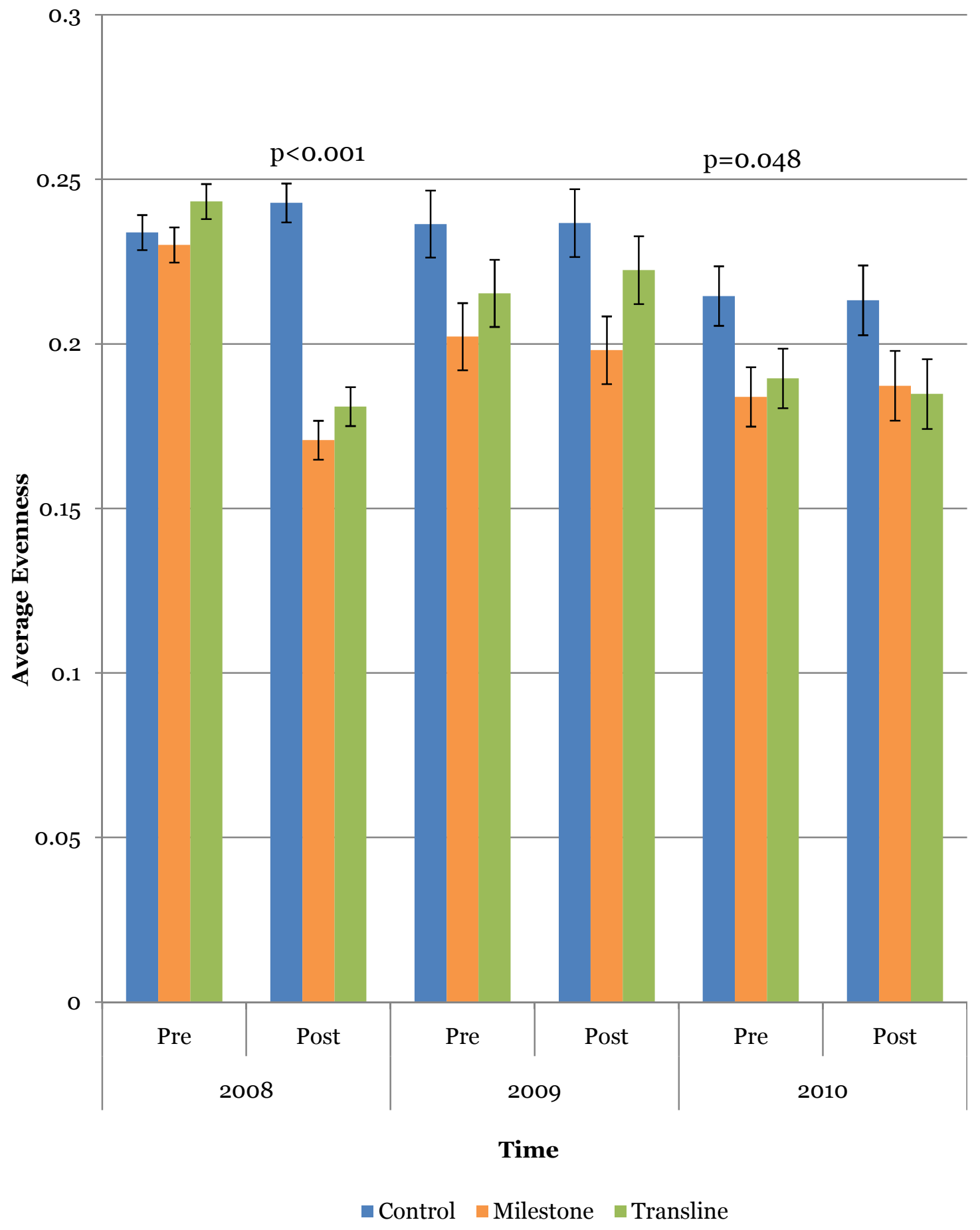

Figure 5.8. Evenness of mean percent cover in treatments of the herbicide study for Pictured Rocks National Lakeshore, Alger County, Michigan. P-values are shown for the significant differences in the contrast between the control treatment and the two herbicide treatments $(\mathrm{df}=1,88)$. 


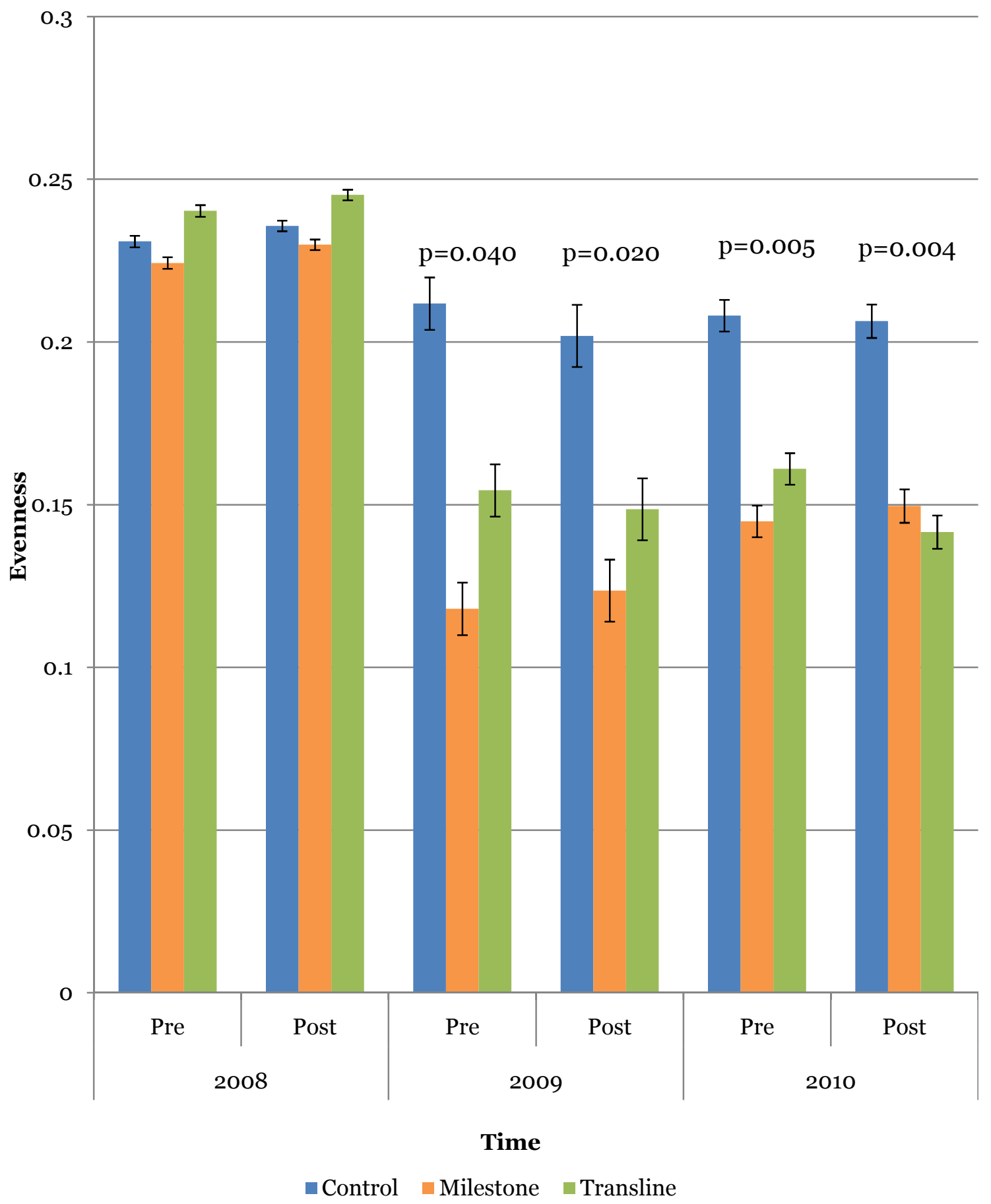

Figure 5.9. Evenness of mean number of individuals in treatments of the herbicide study for Pictured Rocks National Lakeshore, Alger County, Michigan. P-values are shown for the significant differences in the contrast between the control treatment and the two herbicide treatments $(\mathrm{df}=1,88)$. 


\section{Pre-spray 2008}

Table 5.2. Mean percent cover for plant species found in each treatment area of the herbicide study $(\mathrm{df}=1,88)$ in the Grand Sable Dunes of Pictured Rocks National Lakeshore, Alger County, Michigan for Pre-spray 2008 (pre-2008). Plants with numbers too small for analysis are represented by "M."

\begin{tabular}{|c|c|c|c|c|c|}
\hline Species & Control & 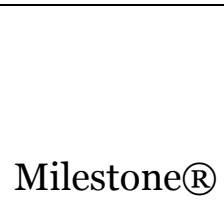 & 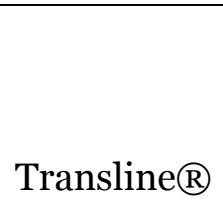 & $\begin{array}{l}\text { Contrast 1: } \\
\text { Control vs. } \\
\text { Herbicide }\end{array}$ & $\begin{array}{c}\text { Contrast 2: } \\
\text { Milestone } \AA \\
\text { vs. } \\
\text { Transline } \AA\end{array}$ \\
\hline Beach Pea & 6.11 & 3.28 & 4.24 & 0.425 & 0.897 \\
\hline Botrychium & M & M & M & M & M \\
\hline Dianthus & M & M & M & M & M \\
\hline Dune cherry & 6.20 & 4.76 & 6.45 & 0.983 & 0.902 \\
\hline Dune stitchwort & 0.00 & 0.15 & 0.00 & 0.779 & 0.476 \\
\hline Evening primrose & 0.00 & 0.67 & 0.33 & 0.458 & 0.770 \\
\hline Goldenrod & 0.67 & 0.48 & 0.82 & 0.999 & 0.862 \\
\hline Graminoid & 35.14 & 37.76 & 36.10 & 0.602 & 0.719 \\
\hline Hairy puccoon & 1.37 & 1.28 & 0.00 & 0.672 & 0.407 \\
\hline Hawkweed & 30.43 & 29.90 & 26.56 & 0.701 & 0.543 \\
\hline Horsetail & 4.93 & 1.60 & 3.17 & 0.431 & 0.784 \\
\hline Jack pine seedling & 0.00 & 0.67 & 0.00 & 0.577 & 0.196 \\
\hline Juniper & M & M & M & M & M \\
\hline Lake Huron tansy & 1.02 & 0.82 & 0.75 & 0.975 & 0.998 \\
\hline Milkweed & 0.00 & 0.00 & 0.33 & 0.779 & 0.476 \\
\hline Ox-eye daisy & 0.00 & 0.00 & 0.15 & 0.779 & 0.476 \\
\hline Plantain & M & M & $\mathrm{M}$ & M & $\mathrm{M}$ \\
\hline Poison ivy & M & M & $\mathrm{M}$ & M & M \\
\hline Red clover & 0.81 & 1.30 & 0.70 & 0.973 & 0.817 \\
\hline Red sorrel & 8.25 & 12.29 & 12.74 & 0.137 & 0.983 \\
\hline Rockcress & M & M & M & M & M \\
\hline Smooth rose & 1.38 & 1.09 & 3.68 & 0.876 & 0.520 \\
\hline $\begin{array}{l}\text { Spotted knapweed } \\
\text { Starry false }\end{array}$ & 65.59 & 66.16 & 67.08 & 0.859 & 0.914 \\
\hline Solomon's seal & 4.29 & 4.04 & 7.40 & 0.771 & 0.342 \\
\hline Wild strawberry & 4.10 & $5 \cdot 73$ & 5.19 & 0.817 & 0.976 \\
\hline Yarrow & 0.15 & 0.15 & 0.15 & 1.000 & 1.000 \\
\hline
\end{tabular}


Table 5.3. Mean number of individuals for plant species found in each treatment area of the herbicide study $(\mathrm{df}=1,88)$ in the Grand Sable Dunes of Pictured Rocks National Lakeshore, Alger County, Michigan for Pre-spray 2008 (pre-2008). Plants with numbers too small for analysis are represented by "M."

\begin{tabular}{|c|c|c|c|c|c|}
\hline Species & Control & Milestone® & Transline $囚$ & $\begin{array}{l}\text { Contrast 1: } \\
\text { Control vs. } \\
\text { Herbicide }\end{array}$ & $\begin{array}{c}\text { Contrast 2: } \\
\text { Milestone } \AA ~ v s . \\
\text { Transline } \AA \\
\end{array}$ \\
\hline Beach Pea & 0.81 & 0.35 & 0.61 & 0.558 & 0.745 \\
\hline Botrychium & M & M & M & M & M \\
\hline Dianthus & M & M & M & M & M \\
\hline Dune cherry & 0.72 & 0.40 & 0.80 & 0.968 & 0.777 \\
\hline Dune stitchwort & 0.00 & 0.02 & 0.00 & 0.784 & 0.498 \\
\hline Evening primrose & 0.00 & 0.05 & 0.02 & 0.328 & 0.670 \\
\hline Goldenrod & 0.07 & 0.07 & 0.11 & 0.957 & 0.878 \\
\hline Graminoid & 57.78 & 64.64 & 59.87 & 0.585 & 0.646 \\
\hline Hairy puccoon & 0.19 & 0.09 & 0.00 & 0.367 & 0.691 \\
\hline Hawkweed & 50.13 & 49.36 & 38.40 & 0.736 & 0.492 \\
\hline Horsetail & 3.17 & 0.72 & 1.47 & 0.449 & 0.878 \\
\hline Jack pine seedling & 0.00 & 0.05 & 0.00 & 0.784 & 0.497 \\
\hline Juniper & M & M & M & M & M \\
\hline Lake Huron tansy & 0.27 & 0.16 & 0.14 & 0.899 & 0.997 \\
\hline Milkweed & 0.00 & 0.00 & 0.02 & 0.784 & 0.497 \\
\hline Ox-eye daisy & 0.00 & 0.00 & 0.02 & 0.784 & 0.497 \\
\hline Plantain & M & M & M & M & M \\
\hline Poison ivy & M & M & M & M & M \\
\hline Red clover & 0.07 & 0.10 & 0.07 & 0.986 & 0.960 \\
\hline Red sorrel & 6.22 & 11.09 & 12.27 & 0.175 & 0.954 \\
\hline Rockcress & M & M & M & M & M \\
\hline Smooth rose & 0.16 & 0.13 & 0.50 & 0.831 & 0.414 \\
\hline $\begin{array}{l}\text { Spotted knapweed } \\
\text { Starry false }\end{array}$ & 188.58 & 192.37 & 183.93 & 0.999 & 0.821 \\
\hline Solomon's seal & 1.56 & 1.32 & 2.95 & 0.892 & 0.455 \\
\hline Wild strawberry & 1.22 & 1.33 & 1.65 & 0.902 & 0.903 \\
\hline Yarrow & M & M & M & M & M \\
\hline
\end{tabular}


Post-spray 2008

Table 5.4. Mean percent cover for plant species found in each treatment area of the herbicide study $(\mathrm{df}=1,88)$ in the Grand Sable Dunes of Pictured Rocks National Lakeshore, Alger County, Michigan for Post-spray 2008 (post-2008). Plants with numbers too small for analysis are represented by "M."

\begin{tabular}{|c|c|c|c|c|c|}
\hline Species & Control & Milestoneß & Transline $\mathbb{R}$ & $\begin{array}{l}\text { Contrast 1: } \\
\text { Control vs. } \\
\text { Herbicides }\end{array}$ & 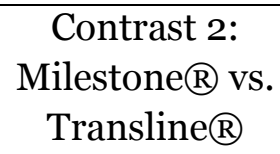 \\
\hline Beach Pea & 4.57 & 1.60 & 2.10 & 0.123 & 0.947 \\
\hline Botrychium & M & $\mathrm{M}$ & M & M & M \\
\hline Dianthus & 0.00 & 0.15 & 0.33 & 0.635 & 0.819 \\
\hline Dune cherry & $5 \cdot 73$ & 1.83 & 2.37 & 0.375 & 0.983 \\
\hline Dune stitchwort & 0.00 & 0.15 & 0.00 & 0.779 & 0.476 \\
\hline Evening primrose & 0.00 & 0.33 & 0.00 & 0.779 & 0.476 \\
\hline Goldenrod & 0.67 & 0.30 & 0.67 & 0.930 & 0.804 \\
\hline Graminoid & 35.18 & 37.76 & 36.40 & 0.565 & 0.803 \\
\hline Hairy puccoon & 1.09 & 0.81 & 0.00 & 0.633 & 0.619 \\
\hline Hawkweed & 29.99 & 29.75 & 26.98 & 0.828 & 0.662 \\
\hline Horsetail & 5.10 & 1.45 & 3.11 & 0.377 & 0.775 \\
\hline Jack pine seedling & 0.00 & 0.67 & 0.58 & 0.494 & 0.990 \\
\hline Juniper & M & M & M & M & M \\
\hline Lake Huron tansy & 1.02 & 0.69 & 0.67 & 0.937 & 1.000 \\
\hline Milkweed & 0.00 & 0.00 & 0.33 & 0.779 & 0.476 \\
\hline Ox-eye daisy & 0.00 & 0.00 & 0.15 & 0.779 & 0.476 \\
\hline Plantain & M & M & M & M & M \\
\hline Poison ivy & M & M & M & M & M \\
\hline Red clover & 0.81 & 0.00 & 0.00 & 0.124 & 1.000 \\
\hline Red sorrel & 7.86 & 12.14 & 11.93 & 0.139 & 0.996 \\
\hline Rockcress & M & $\mathrm{M}$ & M & M & M \\
\hline Smooth rose & 1.38 & 0.58 & 3.12 & 0.966 & 0.484 \\
\hline $\begin{array}{l}\text { Spotted knapweed } \\
\text { Starry false }\end{array}$ & 65.70 & 18.11 & 17.84 & $<0.001$ & 0.997 \\
\hline Solomon's seal & 4.29 & $3 \cdot 30$ & 6.06 & 0.975 & 0.377 \\
\hline Wild strawberry & 4.10 & 4.48 & $4 \cdot 30$ & 0.988 & 0.997 \\
\hline Yarrow & 0.15 & 0.15 & 0.15 & 1.000 & 1.000 \\
\hline
\end{tabular}


Table 5.5. Mean number of individuals for plant species found in each treatment area of the herbicide study $(\mathrm{df}=1,88)$ in the Grand Sable Dunes of Pictured Rocks National Lakeshore, Alger County, Michigan for Post-spray 2008 (post-2008). Plants with numbers too small for analysis are represented by "M."

\begin{tabular}{|c|c|c|c|c|c|}
\hline Species & Control & Milestone® & Transline $\AA$ & $\begin{array}{l}\text { Contrast 1: } \\
\text { Control vs. } \\
\text { Herbicides }\end{array}$ & $\begin{array}{c}\text { Contrast 2: } \\
\text { Milestone } \mathbb{R} \text { vs. } \\
\text { Transline } \mathbb{R}\end{array}$ \\
\hline Beach Pea & 0.45 & 0.31 & 0.02 & 0.230 & 0.827 \\
\hline Botrychium & M & M & M & M & M \\
\hline Dianthus & 0.00 & 0.02 & -0.37 & 0.462 & 0.851 \\
\hline Dune cherry & 0.68 & 0.13 & 0.23 & 0.448 & 0.964 \\
\hline Dune stitchwort & 0.00 & 0.02 & 0.00 & 0.784 & 0.497 \\
\hline Evening primrose & 0.00 & 0.02 & 0.00 & 0.784 & 0.497 \\
\hline Goldenrod & 0.07 & 0.05 & 0.43 & 1.000 & 0.921 \\
\hline Graminoid & 57.88 & 65.74 & 60.89 & 0.483 & 0.657 \\
\hline Hairy puccoon & 0.15 & 0.05 & 0.00 & 0.446 & 0.884 \\
\hline Hawkweed & 48.84 & $45 \cdot 45$ & $37 \cdot 57$ & 0.627 & 0.651 \\
\hline Horsetail & $3 \cdot 31$ & 0.63 & 1.44 & 0.450 & 0.876 \\
\hline Jack pine seedling & 0.00 & 0.05 & 0.02 & 0.670 & 0.872 \\
\hline Juniper & $\mathrm{M}$ & $\mathrm{M}$ & $\mathrm{M}$ & M & $\mathrm{M}$ \\
\hline Lake Huron tansy & 0.27 & 0.16 & 0.13 & 0.881 & 0.991 \\
\hline Milkweed & 0.00 & 0.00 & 0.02 & 0.784 & 0.497 \\
\hline Ox-eye daisy & 0.00 & 0.00 & 0.02 & 0.784 & 0.497 \\
\hline Plantain & M & $\mathrm{M}$ & $\mathrm{M}$ & M & $\mathrm{M}$ \\
\hline Poison ivy & $\mathrm{M}$ & $\mathrm{M}$ & $\mathrm{M}$ & M & $\mathrm{M}$ \\
\hline Red clover & 0.07 & 0.00 & 0.00 & 0.402 & 1.000 \\
\hline Red sorrel & $5 \cdot 56$ & 9.50 & 9.16 & 0.312 & 0.994 \\
\hline Rockcress & M & M & M & M & M \\
\hline Smooth rose & 0.16 & 0.06 & 0.44 & 0.956 & 0.419 \\
\hline $\begin{array}{l}\text { Spotted knapweed } \\
\text { Starry false }\end{array}$ & 189.15 & 10.24 & 10.43 & $<0.001$ & 0.997 \\
\hline Solomon's seal & 1.56 & 1.10 & 2.14 & 1.000 & 0.573 \\
\hline Wild strawberry & 1.12 & 0.93 & 1.05 & 0.910 & 0.937 \\
\hline Yarrow & $\mathrm{M}$ & $\mathrm{M}$ & $\mathrm{M}$ & $\mathrm{M}$ & $\mathrm{M}$ \\
\hline
\end{tabular}




\section{Pre-spray 2009}

Table 5.6. Mean percent cover for plant species found in each treatment area of the herbicide study $(\mathrm{df}=1,88)$ in the Grand Sable Dunes of Pictured Rocks National Lakeshore, Alger County, Michigan for Pre-spray 2009 (pre-2009). Plants with numbers too small for analysis are represented by "M."

\begin{tabular}{|c|c|c|c|c|c|}
\hline Species & Control & Milestone $囚$ & Transline $囚$ & $\begin{array}{l}\text { Contrast 1: } \\
\text { Control vs. } \\
\text { Herbicides }\end{array}$ & $\begin{array}{c}\text { Contrast 2: } \\
\text { Milestone } \mathbb{R} \text { vs. } \\
\text { Transline } \AA\end{array}$ \\
\hline Beach Pea & 2.65 & 7.60 & 0.33 & 0.382 & 0.565 \\
\hline Botrychium & 0.00 & 0.00 & 0.50 & 0.779 & 0.476 \\
\hline Dianthus & M & M & M & M & M \\
\hline Dune cherry & 0.00 & 0.15 & 0.33 & 0.651 & 0.828 \\
\hline Dune stitchwort & 26.36 & 8.37 & 6.98 & $<0.001$ & 0.935 \\
\hline Evening primrose & 0.33 & 0.15 & 0.00 & 0.609 & 0.884 \\
\hline Goldenrod & 4.60 & 1.96 & 4.79 & 0.894 & 0.638 \\
\hline Graminoid & 34.60 & 58.68 & 58.75 & $<0.001$ & 1.000 \\
\hline Hairy puccoon & 1.37 & 3.80 & 0.96 & 0.893 & 0.511 \\
\hline Hawkweed & 0.21 & 0.00 & 0.00 & 0.372 & 1.000 \\
\hline Horsetail & 4.10 & 1.88 & 3.59 & 0.763 & 0.729 \\
\hline Jack pine seedling & 0.00 & 2.30 & 0.00 & 0.602 & 0.223 \\
\hline Juniper & M & $\mathrm{M}$ & M & M & M \\
\hline Lake Huron tansy & 0.00 & 0.30 & 0.33 & 0.492 & 0.993 \\
\hline Milkweed & 4.37 & $3 \cdot 39$ & 7.86 & 0.844 & 0.200 \\
\hline Ox-eye daisy & 0.00 & 0.33 & 0.00 & 0.779 & 0.476 \\
\hline Plantain & M & $\mathrm{M}$ & $\mathrm{M}$ & $\mathrm{M}$ & M \\
\hline Poison ivy & M & M & M & M & M \\
\hline Red clover & 0.91 & 0.00 & 0.00 & 0.137 & 1.000 \\
\hline Red sorrel & 6.89 & 4.98 & 4.08 & 0.570 & 0.941 \\
\hline Rockcress & M & $\mathrm{M}$ & $\mathrm{M}$ & $\mathrm{M}$ & $\mathrm{M}$ \\
\hline Smooth rose & 1.02 & 0.37 & 1.64 & 0.999 & 0.572 \\
\hline $\begin{array}{l}\text { Spotted knapweed } \\
\text { Starry false }\end{array}$ & 39.26 & 8.95 & 10.11 & $<$ O.001 & 0.976 \\
\hline Solomon's seal & 4.29 & 2.47 & 4.67 & 0.942 & 0.655 \\
\hline Wild strawberry & 1.23 & 0.33 & 0.00 & 0.246 & 0.901 \\
\hline Yarrow & 0.00 & 0.15 & 0.00 & 0.779 & 0.476 \\
\hline
\end{tabular}


Table 5.7. Mean number of individuals for plant species found in each treatment area of the herbicide study $(\mathrm{df}=1,88)$ in the Grand Sable Dunes of Pictured Rocks National Lakeshore, Alger County, Michigan for Pre-spray 2009 (pre-2009). Plants with numbers too small for analysis are represented by "M.”

\begin{tabular}{|c|c|c|c|c|c|}
\hline Species & Control & 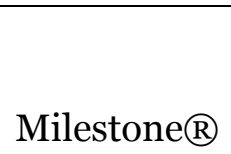 & Transline $\mathbb{R}$ & $\begin{array}{l}\text { Contrast 1: } \\
\text { Control vs. } \\
\text { Herbicides }\end{array}$ & $\begin{array}{c}\text { Contrast 2: } \\
\text { Milestone } \AA \text { vs } \\
\text { Transline } \AA\end{array}$ \\
\hline Beach Pea & 0.45 & 0.31 & 0.02 & 0.441 & 0.476 \\
\hline Botrychium & 0.00 & 0.00 & 0.10 & 0.784 & 0.497 \\
\hline Dianthus & M & M & M & M & M \\
\hline Dune cherry & 0.53 & 0.11 & 0.31 & 0.416 & 0.716 \\
\hline Dune stitchwort & 0.00 & 0.02 & 0.00 & 0.784 & 0.497 \\
\hline Evening primrose & 0.02 & 0.02 & 0.00 & 0.894 & 0.719 \\
\hline Goldenrod & M & M & $\mathrm{M}$ & M & M \\
\hline Graminoid & 48.22 & 98.36 & 103.71 & 0.113 & 0.990 \\
\hline Hairy puccoon & 0.29 & 0.06 & 0.00 & 0.201 & 0.923 \\
\hline Hawkweed & 34.25 & 5.06 & 3.48 & 0.000 & 0.889 \\
\hline Horsetail & 2.59 & 0.81 & 1.85 & 0.561 & 0.689 \\
\hline Jack pine seedling & 0.00 & 0.11 & 0.02 & 0.638 & 0.604 \\
\hline Juniper & M & M & M & 0.583 & 0.230 \\
\hline Lake Huron tansy & 0.22 & 0.07 & 0.48 & 0.990 & 0.478 \\
\hline Milkweed & 0.00 & 0.02 & 0.06 & 0.677 & 0.838 \\
\hline Ox-eye daisy & M & M & M & M & M \\
\hline Plantain & M & M & M & M & M \\
\hline Poison ivy & 0.00 & 0.01 & 0.00 & 0.784 & 0.497 \\
\hline Red clover & 0.07 & 0.00 & 0.00 & 0.402 & 1.000 \\
\hline Red sorrel & 6.22 & 11.09 & 12.27 & 0.745 & 0.973 \\
\hline Rockcress & M & M & M & M & M \\
\hline Smooth rose & 0.18 & 0.61 & 0.15 & 0.534 & 0.115 \\
\hline $\begin{array}{l}\text { Spotted knapweed } \\
\text { Starry false }\end{array}$ & 38.80 & 1.54 & 1.81 & 0.001 & 0.985 \\
\hline Solomon's seal & 1.58 & 1.03 & 3.08 & 0.941 & 0.285 \\
\hline Wild strawberry & 1.36 & 0.66 & 1.60 & 0.936 & 0.535 \\
\hline Yarrow & M & M & M & M & M \\
\hline
\end{tabular}


Post-spray 2009

Table 5.8. Mean percent cover for plant species found in each treatment area of the herbicide study $(\mathrm{df}=1,88)$ in the Grand Sable Dunes of Pictured Rocks National Lakeshore, Alger County, Michigan for Post-spray 2009 (post-2009). Plants with numbers too small for analysis are represented by "M."

\begin{tabular}{|c|c|c|c|c|c|}
\hline Species & Control & 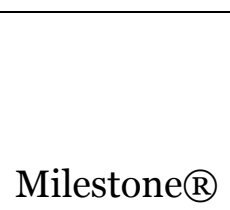 & Transline $\mathbb{R}$ & $\begin{array}{l}\text { Contrast 1: } \\
\text { Control vs. } \\
\text { Herbicides }\end{array}$ & $\begin{array}{c}\text { Contrast 2: } \\
\text { Milestone } \mathbb{} \\
\text { vs. } \\
\text { Transline } \mathbb{R}\end{array}$ \\
\hline Beach Pea & 1.65 & 1.59 & 0.03 & 0.681 & 0.377 \\
\hline Botrychium & 0.00 & 0.00 & 0.46 & 0.809 & 0.527 \\
\hline Dianthus & M & M & M & M & $\mathrm{M}$ \\
\hline Dune cherry & 4.60 & 1.96 & 4.75 & 0.887 & 0.637 \\
\hline Dune stitchwort & 0.00 & 0.15 & 0.00 & 0.772 & 0.473 \\
\hline Evening primrose & 0.33 & 0.15 & 0.00 & 0.610 & 0.888 \\
\hline Goldenrod & $\mathrm{M}$ & $\mathrm{M}$ & $\mathrm{M}$ & M & M \\
\hline Graminoid & 34.63 & 56.15 & 58.47 & $<0.001$ & 0.913 \\
\hline Hairy puccoon & 0.90 & 0.33 & 0.48 & 0.755 & 0.983 \\
\hline Hawkweed & 26.11 & 9.70 & 6.89 & $<0.001$ & 0.762 \\
\hline Horsetail & 4.10 & 1.88 & 3.58 & 0.758 & 0.726 \\
\hline Jack pine seedling & 0.00 & 0.30 & 0.33 & 0.490 & 0.994 \\
\hline Juniper & 0.00 & 2.30 & 0.00 & 0.611 & 0.200 \\
\hline Lake Huron tansy & 1.02 & 0.37 & 1.62 & 1.000 & 0.573 \\
\hline Milkweed & 0.00 & 0.00 & 0.33 & 0.784 & 0.480 \\
\hline Ox-eye daisy & M & M & M & $\mathrm{M}$ & M \\
\hline Plantain & M & M & M & M & M \\
\hline Poison ivy & M & M & M & M & M \\
\hline Red clover & 0.91 & 0.00 & 0.01 & 0.135 & 1.000 \\
\hline Red sorrel & $7 \cdot 56$ & 5.47 & 4.03 & 0.457 & 0.853 \\
\hline Rockcress & $\mathrm{M}$ & $\mathrm{M}$ & $\mathrm{M}$ & $\mathrm{M}$ & M \\
\hline Smooth rose & 1.37 & 3.71 & 0.99 & 0.896 & 0.525 \\
\hline $\begin{array}{l}\text { Spotted knapweed } \\
\text { Starry false }\end{array}$ & 37.01 & 4.93 & 6.02 & $<0.001$ & 0.977 \\
\hline Solomon's seal & 4.70 & 2.56 & 7.48 & 0.989 & 0.132 \\
\hline Wild strawberry & 4.62 & 2.61 & $4 \cdot 31$ & 0.843 & 0.758 \\
\hline Yarrow & 0.21 & 0.00 & 0.00 & 0.370 & 1.000 \\
\hline
\end{tabular}


Table 5.9. Mean number of individuals for plant species found in each treatment area of the herbicide study $(\mathrm{df}=1,88)$ in the Grand Sable Dunes of Pictured Rocks National Lakeshore, Alger County, Michigan for Post-spray 2009 (post-2009). Plants with numbers too small for analysis are represented by "M.”

\begin{tabular}{|c|c|c|c|c|c|}
\hline Species & Control & Milestone $\mathbb{R}$ & Transline $\mathbb{R}$ & $\begin{array}{l}\text { Contrast 1: } \\
\text { Control vs. } \\
\text { Herbicides }\end{array}$ & $\begin{array}{c}\text { Contrast 2: } \\
\text { Milestone } \mathbb{R} \\
\text { vs. } \\
\text { Transline } \mathbb{R}\end{array}$ \\
\hline Beach Pea & 0.33 & 0.28 & 0.00 & 0.609 & 0.429 \\
\hline Botrychium & 0.00 & 0.00 & 0.00 & 0.784 & 0.497 \\
\hline Dianthus & M & M & M & M & M \\
\hline Dune cherry & 0.49 & 0.11 & 0.31 & 0.491 & 0.707 \\
\hline Dune stitchwort & 0.00 & 0.02 & 0.00 & 0.784 & 0.497 \\
\hline Evening primrose & 0.07 & 0.02 & 0.00 & 0.595 & 0.919 \\
\hline Goldenrod & $\mathrm{M}$ & M & M & $\mathrm{M}$ & M \\
\hline Graminoid & 48.40 & 92.73 & 102.85 & 0.120 & 0.958 \\
\hline Hairy puccoon & 0.19 & 0.06 & 0.09 & 0.644 & 0.965 \\
\hline Hawkweed & 33.62 & 6.41 & 3.41 & $<0.001$ & 0.692 \\
\hline Horsetail & 2.53 & 0.81 & 1.85 & 0.575 & 0.675 \\
\hline Jack pine seedling & 0.00 & 0.11 & 0.02 & 0.638 & 0.604 \\
\hline Juniper & 0.00 & 0.07 & 0.00 & 0.583 & 0.230 \\
\hline Lake Huron tansy & 0.22 & 0.07 & 0.48 & 0.990 & 0.478 \\
\hline Milkweed & 0.00 & 0.00 & 0.06 & 0.784 & 0.497 \\
\hline Ox-eye daisy & $\mathrm{M}$ & M & M & $\mathrm{M}$ & M \\
\hline Plantain & M & M & M & M & M \\
\hline Poison ivy & M & M & M & M & M \\
\hline Red clover & 0.07 & 0.00 & 0.00 & 0.402 & 1.000 \\
\hline Red sorrel & 3.71 & 2.76 & 1.95 & 0.744 & 0.910 \\
\hline Rockcress & M & M & M & M & M \\
\hline Smooth rose & 0.18 & 0.54 & 0.13 & 0.586 & 0.116 \\
\hline $\begin{array}{l}\text { Spotted knapweed } \\
\text { Starry false }\end{array}$ & 30.51 & 0.64 & 0.63 & $<0.001$ & 1.000 \\
\hline Solomon's seal & 1.77 & 0.75 & 2.76 & 0.992 & 0.251 \\
\hline Wild strawberry & 1.54 & 0.74 & 1.40 & 0.735 & 0.614 \\
\hline Yarrow & M & M & M & M & M \\
\hline
\end{tabular}


Table 5.10. Mean percent cover for plant species found in each treatment area of the herbicide study $(\mathrm{df}=1,88)$ in the Grand Sable Dunes of Pictured Rocks National Lakeshore, Alger County, Michigan for Pre-spray 2010 (pre-2010). Plants with numbers too small for analysis are represented by "M."

\begin{tabular}{|c|c|c|c|c|c|}
\hline Species & Control & 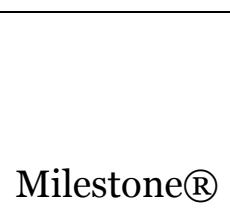 & Transline $\mathbb{R}$ & $\begin{array}{l}\text { Contrast 1: } \\
\text { Control vs. } \\
\text { Herbicides }\end{array}$ & $\begin{array}{c}\text { Contrast 2: } \\
\text { Milestone } \mathbb{} \\
\text { vs. } \\
\text { Transline } \mathbb{R}\end{array}$ \\
\hline Beach Pea & 2.30 & 0.00 & 0.00 & 0.022 & 1.000 \\
\hline Botrychium & 0.00 & 0.00 & 0.50 & 0.779 & 0.476 \\
\hline Dianthus & 0.81 & 0.00 & 0.79 & 0.743 & 0.435 \\
\hline Dune cherry & 3.42 & 1.07 & 4.96 & 0.976 & 0.191 \\
\hline Dune stitchwort & 0.00 & 0.91 & 0.00 & 0.779 & 0.476 \\
\hline Evening primrose & 0.00 & 0.33 & 1.95 & 0.302 & 0.168 \\
\hline Goldenrod & $\mathrm{M}$ & $\mathrm{M}$ & $\mathrm{M}$ & $\mathrm{M}$ & M \\
\hline Graminoid & 51.89 & 83.66 & 73.09 & $<0.001$ & 0.329 \\
\hline Hairy puccoon & 0.91 & 0.67 & 0.00 & 0.594 & 0.596 \\
\hline Hawkweed & 19.75 & 11.90 & 8.27 & $\mathbf{0 . 0 1 7}$ & 0.636 \\
\hline Horsetail & 7.85 & 2.20 & 3.93 & 0.132 & 0.816 \\
\hline Jack pine seedling & $\mathrm{M}$ & $\mathrm{M}$ & $\mathrm{M}$ & $\mathrm{M}$ & M \\
\hline Juniper & M & M & M & $\mathrm{M}$ & $\mathrm{M}$ \\
\hline Lake Huron tansy & 0.75 & 1.02 & 0.82 & 0.986 & 0.987 \\
\hline Milkweed & 0.95 & 0.33 & 0.00 & 0.340 & 0.861 \\
\hline Ox-eye daisy & 0.00 & 0.00 & 1.09 & 0.643 & 0.270 \\
\hline Plantain & 0.33 & 0.33 & 1.38 & 0.807 & 0.527 \\
\hline Poison ivy & 0.00 & 0.00 & 0.47 & 0.779 & 0.476 \\
\hline Red clover & 1.14 & 0.33 & 0.33 & 0.461 & 1.000 \\
\hline Red sorrel & 6.01 & 13.08 & 11.82 & 0.040 & 0.909 \\
\hline Rockcress & 0.00 & 0.15 & 0.00 & 0.779 & 0.476 \\
\hline Smooth rose & 1.75 & 0.60 & 1.28 & 0.809 & 0.959 \\
\hline $\begin{array}{l}\text { Spotted knapweed } \\
\text { Starry false }\end{array}$ & 47.90 & 17.75 & 26.48 & $<0.001$ & 0.473 \\
\hline Solomon's seal & 7.86 & $5 \cdot 58$ & 6.12 & 0.599 & 0.973 \\
\hline Wild strawberry & 1.95 & 1.21 & 3.48 & 0.972 & 0.497 \\
\hline Yarrow & 0.33 & 0.00 & 0.47 & 0.972 & 0.612 \\
\hline
\end{tabular}


Table 5.11. Mean number of individuals for plant species found in each treatment area of the herbicide study $(\mathrm{df}=1,88)$ in the Grand Sable Dunes of Pictured Rocks National Lakeshore, Alger County, Michigan for Pre-spray 2010 (pre-2010). Plants with numbers too small for analysis are represented by "M."

\begin{tabular}{|c|c|c|c|c|c|}
\hline Species & Control & Milestone $\mathbb{R}$ & Transline $\mathbb{R}$ & $\begin{array}{l}\text { Contrast 1: } \\
\text { Control vs. } \\
\text { Herbicides }\end{array}$ & $\begin{array}{c}\text { Contrast 2: } \\
\text { Milestone } \mathbb{R} \\
\text { vs. } \\
\text { Transline } \mathbb{R}\end{array}$ \\
\hline Beach Pea & 0.26 & 0.00 & 0.00 & 0.037 & 1.000 \\
\hline Botrychium & 0.00 & 0.00 & 0.10 & 0.784 & 0.497 \\
\hline Dianthus & 0.08 & 0.00 & 0.15 & 0.995 & 0.274 \\
\hline Dune cherry & 0.25 & 0.02 & 0.29 & 0.743 & 0.245 \\
\hline Dune stitchwort & 0.00 & 0.27 & 0.00 & 0.784 & 0.497 \\
\hline Evening primrose & 0.02 & 0.02 & 0.00 & 0.382 & 0.270 \\
\hline Goldenrod & $\mathrm{M}$ & M & M & $\mathrm{M}$ & M \\
\hline Graminoid & 89.24 & 220.56 & 180.13 & 0.009 & 0.697 \\
\hline Hairy puccoon & 0.08 & 0.05 & 0.00 & 0.696 & 0.804 \\
\hline Hawkweed & 16.94 & $7 \cdot 77$ & 4.85 & o.034 & 0.719 \\
\hline Horsetail & 4.54 & 0.74 & 1.66 & 0.435 & 0.910 \\
\hline Jack pine seedling & $\mathrm{M}$ & $\mathrm{M}$ & $\mathrm{M}$ & M & M \\
\hline Juniper & M & M & M & M & M \\
\hline Lake Huron tansy & 0.22 & 0.07 & 0.48 & 0.990 & 0.478 \\
\hline Milkweed & 0.12 & 0.04 & 0.00 & 0.379 & 0.845 \\
\hline Ox-eye daisy & 0.00 & 0.00 & 0.14 & 0.568 & 0.215 \\
\hline Plantain & 0.06 & 0.02 & 0.35 & 0.865 & 0.509 \\
\hline Poison ivy & 0.00 & 0.00 & 0.02 & 0.784 & 0.497 \\
\hline Red clover & 0.23 & 0.02 & 0.02 & 0.505 & 1.000 \\
\hline Red sorrel & 2.44 & 8.93 & 9.74 & 0.019 & 0.975 \\
\hline Rockcress & 0.00 & 0.02 & 0.00 & 0.784 & 0.498 \\
\hline Smooth rose & 0.09 & 0.28 & 0.11 & 0.905 & 0.823 \\
\hline $\begin{array}{l}\text { Spotted knapweed } \\
\text { Starry false }\end{array}$ & $39 \cdot 32$ & 2.52 & 4.84 & 0.004 & 0.680 \\
\hline Solomon's seal & 3.29 & 2.15 & 2.71 & 0.802 & 0.923 \\
\hline Wild strawberry & 0.37 & 0.16 & 0.89 & 0.959 & 0.381 \\
\hline Yarrow & M & M & M & M & M \\
\hline
\end{tabular}




\section{Post-spray 2010}

Table 5.12. Mean percent cover for plant species found in each treatment area of the herbicide study $(\mathrm{df}=1,88)$ in the Grand Sable Dunes of Pictured Rocks National Lakeshore, Alger County, Michigan for Post-spray 2010 (post-2010). Plants with numbers too small for analysis are represented by "M."

\begin{tabular}{|c|c|c|c|c|c|}
\hline Species & Control & Milestone $囚$ & Transline $®$ & $\begin{array}{l}\text { Contrast 1: } \\
\text { Control vs. } \\
\text { Herbicides }\end{array}$ & $\begin{array}{c}\text { Contrast 2: } \\
\text { Milestone } \mathbb{} \\
\text { vs. } \\
\text { Transline } \mathbb{8}\end{array}$ \\
\hline Beach Pea & 2.24 & 0.00 & 0.00 & 0.018 & 1.000 \\
\hline Botrychium & 0.23 & 0.00 & 0.50 & 0.781 & 0.451 \\
\hline Dianthus & 0.77 & 0.00 & 0.79 & 0.745 & 0.409 \\
\hline Dune cherry & 3.99 & 1.07 & 4.60 & 0.880 & 0.261 \\
\hline Dune stitchwort & 0.04 & 0.71 & 0.00 & 0.781 & 0.451 \\
\hline Evening primrose & 0.09 & 0.33 & 1.95 & 0.293 & 0.148 \\
\hline Goldenrod & M & M & M & $\mathrm{M}$ & M \\
\hline Graminoid & $47 \cdot 35$ & 83.66 & 73.09 & $<0.001$ & 0.330 \\
\hline Hairy puccoon & 0.78 & 0.67 & 0.00 & 0.687 & 0.577 \\
\hline Hawkweed & 20.32 & 11.90 & 8.27 & 0.005 & 0.620 \\
\hline Horsetail & 7.40 & 2.20 & 3.93 & 0.135 & 0.805 \\
\hline Jack pine seedling & $\mathrm{M}$ & M & M & $\mathrm{M}$ & $\mathrm{M}$ \\
\hline Juniper & M & M & M & $\mathrm{M}$ & M \\
\hline Lake Huron tansy & 0.69 & 1.02 & 0.82 & 0.975 & 0.988 \\
\hline Milkweed & 0.85 & 0.33 & 0.98 & 0.365 & 0.852 \\
\hline Ox-eye daisy & 0.03 & 0.00 & 1.09 & 0.625 & 0.246 \\
\hline Plantain & 0.38 & 0.33 & 1.38 & 0.808 & 0.503 \\
\hline Poison ivy & 0.00 & 0.00 & 0.47 & 0.733 & 0.452 \\
\hline Red clover & 1.55 & 0.33 & 0.33 & 0.277 & 1.000 \\
\hline Red sorrel & 6.55 & 13.08 & 11.82 & 0.039 & 0.903 \\
\hline Rockcress & 0.01 & 0.15 & 0.00 & 0.781 & 0.451 \\
\hline Smooth rose & 0.59 & 1.75 & 1.28 & 0.769 & 0.957 \\
\hline $\begin{array}{l}\text { Spotted knapweed } \\
\text { Starry false }\end{array}$ & $47 \cdot 58$ & 2.47 & 2.04 & $<0.001$ & 0.994 \\
\hline Solomon's seal & 7.86 & 5.58 & 6.12 & 0.571 & 0.974 \\
\hline Wild strawberry & 2.38 & 1.21 & 3.48 & 1.000 & 0.505 \\
\hline Yarrow & 0.30 & 0.00 & 0.47 & 0.987 & 0.591 \\
\hline
\end{tabular}


Table 5.13. Mean number of individuals for plant species found in each treatment area of the herbicide $(\mathrm{df}=1,88)$ study in the Grand Sable Dunes of Pictured Rocks National Lakeshore, Alger County, Michigan for Post-spray 2010 (post-2010). Plants with numbers too small for analysis are represented by "M."

\begin{tabular}{|c|c|c|c|c|c|}
\hline Species & Control & Milestone® & Transline $\mathbb{R}$ & $\begin{array}{l}\text { Contrast 1: } \\
\text { Control vs. } \\
\text { Herbicides }\end{array}$ & $\begin{array}{c}\text { Contrast 2: } \\
\text { Milestone } \mathbb{R} \\
\text { vs. } \\
\text { Transline } \mathbb{R}\end{array}$ \\
\hline Beach Pea & 0.26 & 0.00 & 0.00 & 0.037 & 1.000 \\
\hline Botrychium & 0.00 & 0.00 & 0.10 & 0.784 & 0.497 \\
\hline Dianthus & 0.08 & 0.00 & 0.15 & 0.995 & 0.274 \\
\hline Dune cherry & 0.25 & 0.02 & 0.32 & 0.796 & 0.181 \\
\hline Dune stitchwort & 0.00 & 0.27 & 0.00 & 0.784 & 0.497 \\
\hline Evening primrose & 0.00 & 0.02 & 0.14 & 0.382 & 0.270 \\
\hline Goldenrod & M & M & M & $\mathrm{M}$ & M \\
\hline Graminoid & 89.24 & 220.56 & $175 \cdot 44$ & 0.012 & 0.647 \\
\hline Hairy puccoon & 0.08 & 0.05 & 0.00 & 0.696 & 0.804 \\
\hline Hawkweed & 16.94 & $7 \cdot 77$ & $3 \cdot 71$ & 0.014 & 0.460 \\
\hline Horsetail & 4.54 & 0.74 & 1.66 & 0.435 & 0.910 \\
\hline Jack pine seedling & M & M & M & $\mathrm{M}$ & M \\
\hline Juniper & M & M & M & M & M \\
\hline Lake Huron tansy & 0.22 & 0.07 & 0.48 & 0.990 & 0.478 \\
\hline Milkweed & 0.12 & 0.04 & 0.00 & 0.379 & 0.845 \\
\hline Ox-eye daisy & 0.00 & 0.00 & 0.14 & 0.568 & 0.215 \\
\hline Plantain & 0.06 & 0.02 & 0.35 & 0.865 & 0.509 \\
\hline Poison ivy & 0.00 & 0.00 & 0.02 & 0.784 & 0.497 \\
\hline Red clover & 0.23 & 0.02 & 0.02 & 0.505 & 1.000 \\
\hline Red sorrel & 2.44 & 8.93 & 7.47 & o.035 & 0.899 \\
\hline Rockcress & 0.00 & 0.02 & 0.00 & 0.784 & 0.497 \\
\hline Smooth rose & 0.09 & 0.28 & 0.11 & 0.905 & 0.823 \\
\hline $\begin{array}{l}\text { Spotted knapweed } \\
\text { Starry false }\end{array}$ & 34.03 & 0.21 & 0.15 & $<$ 0.001 & 0.990 \\
\hline Solomon's seal & 3.29 & 2.15 & 2.71 & 0.802 & 0.923 \\
\hline Wild strawberry & 0.37 & 0.16 & 0.89 & 0.959 & 0.381 \\
\hline Yarrow & M & M & M & M & M \\
\hline
\end{tabular}




\section{Dissertation Literature Cited}

Alien Plant Working Group. 2002.Weeds Gone Wild: Alien Plant Invaders of Natural Areas. Plant Conservation Alliance. http://www.nps.gov/plants/alien/bkgd.htm. Accessed: January 1, 2011.

Anderson, R. C., S. S. Dhillion, and T. M. Kelley. 1996. Aspects of the ecology of an invasive plant, garlic mustard (Alliaria petiolata), in central Illinois. Restoration Ecology 4:181-191.

Bach, David P. 1978. Plant communities, habitats, and soil conditions of Grand Sable Dunes, Pictured Rocks National Lakeshore, Michigan. M.S. Thesis. Houghton, Michigan: Michigan Technological University. 180 p.

Bailey, W.W. 1987. Journal of the Torrey Botanical Society 3: 176.

Bais, H.P., R. Vepachedu, S. Gilroy, R.M. Callaway, and J.M. Vivanco. 2003. Allelopathy and exotic plant invasion: from molectules and genes to species interactions. Science 301(5638) 1377-1380.

Baker, B. 2001. National management plan maps strategy for controlling invasive species. Bioscience 51: 92.

Baker, H.G. 1984. Patterns of plant invasion in North America. Pp. 44-57 in Mooney, H.A. and J. A. Drake, eds. Ecology of biological invasions in North America and Hawaii. New York: Springer-Verlag.

Baskin, J. M. and C. C. Baskin. 1992. Seed germination biology of the weedy biennial Alliaria petiolata. Natural Areas Journal 12:191-197.

Beard, J.S. 1978. The physiognomic approach. Pp. 33-64 in R.H. Whittaker, ed. Classification of plant communities. Junk, The Hague.

Belote, T.R., J.F. Weltzin, R.J. Norby. 2003. Response of an understory plant community to elevated $\mathrm{CO} 2$ depends on differential responses of dominant invasive species and is mediated by soil water availability. New Phytologist161: 827-835.

Blair, A.C., S.J. Nissen, G.R. Brunk, and R.A. Hufbauer. 2006. A lack of evidence for an ecological role of the putative allelochemical $( \pm)$-catechin in spotted knapweed invasion success. The Journal of Chemical Ecology 32: 2327-2331.

Bomar, M.A. 2007. NPS Centennial Initiative Program: Centennial strategy for Pictured Rocks National Lakeshore.

Booth, M.S., M.M. Caldwell, and J.M. Stark. 2003. Overlapping resource us in three Great Basin species: implications for community invasibility and vegetation dynamics. Journal of Ecology 91: 36-48.

Borg-Karlson, A. K., I. Valternova, and L. A. Nilsson. 1994. Volatile compounds of flowers of six species in the family Apiaceae: bouquets for different pollinators? Phytochemistry 35: 111-118. 
Bradfield, G.E. and L. Orloci. 1975. Classification of vegetation data from an open beach environment in southwestern Ontario: cluster analysis followed by generalized distance assignments. Canadian Journal of Botany 53:495-502.

Bradley, B.A., M. Oppenheimer, D.S. Wilcove. 2009. Climate change and plant invasions: restoration opportunities ahead? Global Change Biology 15: 1511-1521.

Breshears, D.D., N.S. Cobb, P.M. Rich, K.P. Price, C.D. Allen, R.G. Balice, W.H. Romme, J.H. Kastens, M.L. Floyd, J. Beinap, J.J. Anderson, O.B. Myers, and C.W. Meyer. 2005. Regional vegetation die-off in response to global-change-type drought. Proceedings of the National Academy of Sciences 102(42): 15144-15148.

Byers, J., S. Reichard, J.M. Randall, I.M. Parker, C.S. Smith, W.M. Lonsdale, I.A.E. Atkinson, M. Williamson, E. Choresky, and D. Hayes. 2002. Directing research to reduce the impacts of nonindigenous species. Conservation Biology 6:630-640.

Carpinelli, M. 2003. Spotted knapweed invasive exotic plant tutorial. USDA-ARS Burns, Oregon.

Carroll, A.L., S.W. Taylor, J. Regniere, and L. Safranyik. 2004. Effects of climate change on range expansion by the mountain pine beetle in British Columbia. Pp. 223-232 in I. Shore, J.E. Brooks, and J.E. Stone, eds. Mountain Pine Beetle Symposium: Challenges and Solutions. National Resources Canada, Canadian Forest Service, Pacific Forestry Centre, Kelowna, BC.

Cavers, P. B., M. I. Heagy, and R. F. Kokron. 1979. The biology of Canadian weeds. Canadian Journal of Plant Science 59:217-229.

Ciesla, W.M. 2000. Remote sensing in forest health protection. USDA Forest Service, Forest Health Technology Enterprise Team, Fort Collins, CO.

Cizek, O., A. Bakesova, T. Kuras, J. Benes, M. Konvicka. 2004. Vacant niche in alpine habitat: the case of an introduced population of the butterfly Erebia epiphron in the Krkonose mountains. Acta Oecologica 24:1.

Colautti, R.I., and H.J. MacIsaac. 2004. A neutral terminology to define invasive species. Diversity and Distributions 10:135-141.

Cousens, R., and M. Mortimer. 1995. Dynamics of weed populations. Cambridge University Press, Cambridge. 332 p.

D’Antonio C.M, and P.M. Vitousek.1992.Biological invasions by exotic grasses, the grass/fire cycle, and global change. Annual Review of Ecology and Systematics 23: $63-87$.

Daehler C.C. and D.R. Strong. 1994. Native plant bio- diversity vs. the introduced invaders: status of the conflict and future management options. Pp. 92-113 in S.K. Majumdar, F.J. Brenner, J.E. Lovich, J.F. Schalles, E.W. Miller, eds. Biological Diversity: Problems and Challenges. Easton, PA: Penn. Acad. Sci. 
Daehler, C. 1998. The taxonomic distribution of invasive angiosperm plants: ecological insights and comparison to agricultural weeds. Biological Conservation 84:167180.

Dale, V.H., L.A. Joyce, S. McNulty, R.P. Neilson, M.P. Ayers, M.D. Flannigan, P.J. Hanson, L.C. Irland, A.E. Lugo, C.J. Peterson, D. Simberloff, F.J. Swanson, B.J. Stocks, and B.M. Wotton. 2001. Climate change and forest disturbances. BioScience 51 (9): 723-734.

Dark, S.J. 2004. The biogeography of invasive alien plants in California: an application of GIS and spatial regression analysis. Diversity Distribution 10: 1-9.

Davis, E.S., P.K. Fay, T.K. Chicoine, and C.A. Lacey. 1993. Persistence of spotted knapweed (Centaurea maculosa) seed in soil. Weed Science 41: 57-61.

Davis, M.A., J.P. Grime, K. Thompson. 2000. Fluctuating resources in plant communities: a general theory of invasibility. Journal of Ecology 88: 528-534.

Dekker, J. 2005. Biology and anthropology of plant invasions. Pp. 235-250 in O. Inderjit, ed. Invasive Plants: Ecological and Agricultural Aspects. Birkhauser Verlag, Switzerland.

Dennis, J.G. 1999. National Park Service Management Policies for the National Park System. The George Wright FORUM 16(3): 7-18.

Dlussky, G. M. 1998. Mechanisms of competition for pollinators in Anthriscus sylvestris Hoffm. and Aegopodium podagraria L. (Apiaceae). Zhurnal Obshchei Biologii 59: 24-44. Everett, T. H. 1981.

Dollemore, D. 2005. Controlling the spread of invasive plants: a national effort. Science Blog. www.scienceblog.com. Accessed: August 2005.

Dow AgroSciences. 2011a. Milestone® Fact Sheet. http://www.dowagro.com/Published Literature/dh_o2b1/o901b803802b1ofc.pdf?filepath=range/pdfs/noreg/o1056950.pdf\&fromPage=GetDoc. Accessed: March 2011.

Dow AgroSciences. 2011b. Transline $囚$ Fact Sheet. http://msdssearch.dow.com/ PublishedLiteratureDAS/dh_o6e1/o901b803806e1d8f.pdf?filepath=ivm/pdfs/n oreg/o10-50843.pdf\&fromPage=GetDoc. Accessed: March 2011.

Duke, J.A. 1981. Handbook of legumes of world economic importance. New York: Plenum Press.

Duke, J.A. 1984. Borderline herbs. Boca Raton, FL: CRC Press.

Environmental Protection Agency. 2011. Pesticides: regulating pesticides. http://www.epa.gov/poordoo1/workplan/reducedrisk.html. Accessed: March 2011. 
Fei, S., N. Kong, J. Stringer, D. Bowker. 2009. Invasion pattern of exotic plants in forest ecosystems. Pp. 59-70 in R.K. Kohli, S. Jose, H.P. Singh, D.R. Batish, eds. Invasive Plants and Forest Ecosystems. Boca Raton, Florida: CRC Press.

Firbank, L.G., A.R. Watkinson, L.R. Norton, T.W. Ashenden. 1995. Plant populations and global environmental change: the effect of different temperature, carbon dioxide, and nutrient regimes on density dependence in populations of Vilpia ciliata. Journal of Applied Ecology 9: 432-441.

Fletcher, R.A., and A.J. Renney. 1963. A growth inhibitor found in Centaurea spp. Canadian Journal of Plant Science 43:475-481.

Freeman, J.E., R. Albritton, S. Jose, and J.R.R. Alavalapati. 2009. The economics, law, and policy of invasive species management in the United States: responding to a growing crisis. Pp. 409-426 in R. Kohli, S. Jose, H.P. Singh, D.R. Batish, eds. Invasive Plants and Forest Ecosystems. Boca Raton, Florida: CRC Press.

Frelich, L.E. 2002. Forest Dynamics and Disturbance Regimes. Cambridge University Press: New York. 266 pp.

Garcia-Mora, M.R., J.B. Gallego-Fernandez, and F. Garcia-Novo. 200o. Plant diversity as a suitable tool for coastal dune vulnerability assessment. The Journal of Coastal Research 16: 990-995.

Gatsuk, L. E., O. V. Smirnova, L. I. Vorontzova, L. B. Zaugolnova, and L. A. Zhukova. 1980. Age states of plants of various growth forms: a review. Journal of Ecology 68: 675-696.

Gattuso, D.J. 2006. Invasive species: animal, vegetable, or political? National Policy Analysis. 544.

Gilkey, H. 1957. Weeds of the Pacific Northwest. Oregon State College, OR.

Gleason, H. A., and A. Cronquist. 1991. Manual of vascular plants of northeastern United States and adjacent Canada, 2nd ed. New York Botanical Garden, New York.

Goodwin, B.J., A.J. McAllister, and L. Fahrig. 1999. Predicting invasiveness of plant species based on biological information. Conservation Biology 13: 422-426.

Gordon, H.L. 1881. Legends of the Northwest including 'The Sea Gull': The Ojibwa Legend of the Pictured Rocks of Lake Superior. St. Paul, MN: St. Paul Book and Stationery Co. 143 p.

GrandSableDunesColor\%202008.pdf. Accessed: April 2009.

Great Lakes Shoreline Recreation Area Survey. 1959. Remaining Shoreline Opportunities in Minnesota, Wisconsin, Illinois, Indiana, Ohio, Michigan, Pennsylvania, New York. United States Department of the Interior. 
Grime, J. P., J. G. Hodges, and R. Hunt. 1988. Comparative plant ecology. Unwin Hyman, London.

Groves, R.H. 1999. Sleeper weeds. Pp. 632-636 in A.C. Bishop, M. Boersma, and C.D. Barnes, eds. Weed Management into the $21^{\text {st }}$ Century: do we know where we are going? Proceedings of the $12^{\text {th }}$ Australian Weeds Conference. Tasmainian Weeds Society, Hobart.

Groves, R.H. 2006. Are some weeds sleeping? Some concepts and reasons. Euphutica 148:111-120.

Grzesiak, K. 2010. Pictured Rocks National Lakeshore Exotic Plant Management Team Handbook.

Haragan, P.D. 1991. Weeds of Kentucky and adjacent states: a field guide. The University Press of Kentucky. Lexington, Kentucky.

Hayek, L.C. and M.A. Buzas. 1997. Surveying natural populations. New York: Columbia University Press. 563 p.

Hiebert, R.D. 1997. Prioritizing invasion plants and planning for management. Pp. 195212 in J.O. Luken and J.W. Thieret, eds. Assessment and Management of Plant Invasions. Springer-Verlag, New York, NY.

Hobbs, R.J. and S.E. Humphries. 1995. An integrated approach to the ecology and management of plant invasions. Conservation Biology 9:761-770.

Hobbs, R.J., A. Salvatore, J. Aronson, J.S. Baron, P. Bridgewater, V.A. Cramer, P.R. Epstein, J.J. Ewel, C.A. Klink, A.E. Lugo, D. Norton, D. Ojima, D.M. Richardson, E.S. Sanderson, F. Valladares, M. Villa, R. Zamora, and M. Zobel. 2006. Novel ecosystems: theoretical and management aspects of the new ecological world order. Global Ecology and Biogeography. 15:1-17.

Hoffman, R. and K. Kearns, eds. 1997. Wisconsin manual of control recommendations for ecologically invasive plants. Wisconsin Dept. Natural Resources. Madison, Wisconsin.

Holcombe, T., and T.J. Stohlgren. 2009. Detection and early warning of invasive species. Pp. 36-46 in M.N. Clout and P.A. Williams, eds. Invasive Species Management. Oxford: Oxford University Press.

Holt, J.S. 2009. Management of invasive terrestrial plants. Pp. 126-140 in M.N. Clout and P.A. Williams, eds. Invasive Species Management. Oxford: Oxford University Press.

Hurteau, M. and M. North. 2008. Mixed-conifer understory response to climate change, nitrogen, and fire. Global Change Biology 14: 1543-1552.

Intergovernmental Panel on Climate Change. 2007. In S. Solomon, D. Qin, M. Manning, Z. Chen, M. Marquis, and K.B. Averyt, eds. Climate Change 2007: The Physical Science Basis. Contribution of Working Group I to the Fourth Assessment Report 
of the Intergovernmental Panel on Climate Change. Cambridge University Press, Cambridge, UK.

Inventory and Monitoring Program. 2010. National Park Service. http://science.nature.nps.gov/im/index.cfm. Accessed: April 2010.

Iverson, L.R. and A.M. Prasad. 1998. Predicting abundance of 80 tree species following climate change in the eastern United States. Ecological Monographs 68(4): 465485 .

Jacobs, J. S. and R. L. Sheley. 1998. Observation: life history of spotted knapweed. J Range Manage 51:665-673.

Jager, H.I. and W.S. Overton. 1993. Explanatory models for ecological response surfaces. Environmental Monitoring with GIS. New York: Oxford University Press.

Karamanski, T.J. 1995. The Pictured Rocks: An Administrative History of Pictured Rocks National Lakeshore. United States Department of the Interior.

Kareiva, P., S. Watts, R. McDonald, and T. Boucher. 2007. Domesticated nature: shaping landscapes and ecosystems for human welfare. Science 316 (5833): 1866-1869.

Kedzie-Webb, S.A., R.L. Sheley, J.J. Borowski, and J.S. Jacobs. Relationships between Centaurea maculosa and indigenous plant assemblages. Western North American Naturalist 61(1): 43-49.

Kelly, A.E. and M.L. Goulden. 2008. Rapid shifts in plant distribution with recent climate change. Proceedings of the National Academy of Sciences 105(33): 1182311826.

Kennedy, T.A., S. Naeem, K.M. Howe, J.M.H. Knops, D. Tilman, and P. Reigh. 2002. Biodiversity as a barrier to ecological invasion. Nature 417: 636-638.

Kolar, C.S. and D.M. Lodge. 2001. Progress in invasion biology: predicting invaders. Trends in Ecology and Evolution 16:199-204.

Kumler, M.L. 1969. Plant succession of the sand dunes of the Oregon coast. Ecology 50:695-704.

Kurz, W.A., C.C. Dymond, G. Stinson, G.J. Rampley, E.T. Neilson, A.L. Carroll, T. Ebata, and L. Safranyik. Mountain pine beetle and forest carbon feedback to climate change. Nature 452: 987-990.

Lavergne, S., and J. Molofsky. 2004. Reed canary grass (Phalaris arundinacea) as a biological model in the study of plant invasions. Critical Reviews in Plant Sciences 23(5):415-429.

Lawrence, G. 1959. Vinca and CATHARANTHUS. Baileya 7:113.

LeBlanc, D. 2008. Certified weed management area formalized for the central Upper Peninsula of Michigan. USFS Success Stories. 
Leege, L.M. and P.G. Murphy. 2001. Ecological effects of the non-native Pinus nigra on sand dune communities. Canadian Journal of Botany 79: 429-427.

Leutscher, B. and G. Bruff. Pictured Rocks news. June 19, 2008. www.nps.gov/piro/parknews/control-invasives.htm. Accessed April 2010.

Levy, P.S. and S. Lemeshow. 1999. Sampling of Populations. New York, New York: John Wiley \& Sons.

Lichter, J. 2000. Colonization constraints during primary succession on coastal Lake Michigan sand dunes. Journal of Ecology 88: 825-839.

Lockwood, J.L., D. Simberloff, M.L. McKinney and B. Von Holle. 2001. How many, and which, plants invade natural areas? Biological Invasions 3: 1-8.

Lym, R.G. and R.K. Zollinger. 1992. Spotted knapweed (Centaurea maculosa Lam.). NDSU Extension Service, North Dakota State University of Agriculture and Applied Science.

MacDonald, N.W., B.T. Scull, and S.R. Abella. 2007. Mid-spring burning reduces spotted knapweed and increases native grasses during a Michigan experimental grassland establishment. Restoration Ecology 15: 118-128.

Mack, M.C. and C.M. D’Antonio. 1998. Impacts of biological invasions on disturbance regimes. Trends in Ecology and Evolution 13:195-198.

Mack, R.N. 1996. Predicting the identity and fate of plant invaders: emergent and emerging approaches. Biological Conservation 78:107-121.

Mack, R.N., and W.M. Lonsdale. 2001. Humans as global plant disperseres: getting more than we bargained for. BioScience 51:95-102.

Maron, J. and M. Marler. 2007. Native plant diversity resists invasion at both low and high resource levels. Ecology 88(10): 2651-2661.

Maron, J. and M. Marler. 2008. Field-based competitive impacts between invaders and natives at varying resource supply. Journal of Ecology 96: 1187-1197.

Marshall, J.M., A.J. Storer, and B. Leutscher. 2008. Comparative analysis of plant and ground dwelling arthropod communities in lacustrine dune areas with and without Centaurea biebersteinii (Asteraceae). The American Midland Naturalist 159(2):261-274.

Maun, M.A. 1994. Adaptations enhancing survival and establishment of seedlings on coastal dune systems. Plant Ecology 111(1): 59-70.

McClintock, E. 1985. Escaped exotic weeds in California. Fremontia 12:3 6.

McNeely, J.A., H.A. Mooney, L.E. Neville, P.J. Schei, and J.K. Waage, eds. 2001. Global Strategy on Invasive Alien Species. Cambridge: IUCN in collaboration with the Global Invasive Species Programme. 
McRoberts, R.E., R.J. Barbour, K.M. Gebert, G.C. Liknes, M.D. Nelson, D.M. Meneguzzo, S.L. Odell, S.C. Yaddof, S.M. Stein, H.T. Mowrer, K.L. Gerlitz, and W.M. Gerlitz. 2006. Using basic Geographic Information Systems functionality to support sustainable forest management decision making and post-decision assessments. Journal of Sustainable Forestry 23(3).

Meiners, S.J. and M.L. Cadenasso. 2005. The relationship between community diversity and exotic plants: cause or consequence of invasion? Invasive plants: Ecological and Agricultural Aspects. Pp. 97-114.

Meiners, S.J. and M.L. Cadenasso. 2005. The relationship between community diversity and exotic plants: cause or consequence of invasion? Invasive plants: Ecological and Agricultural Aspects. Pp. 97-114.

Michigan Department of National Resources and Environment. 2009. Michigan's Official List of Endangered and Threatened Species.

Miller, James H. 2003. Nonnative invasive plants of southern forests: a field guide for identification and control. Gen. Tech. Rep. SRS-62. Asheville, NC: U.S. Department of Agriculture, Forest Service, Southern Research Station. 93 p.

Mladenoff, D.J. and F. Stearns. 1993. Eastern Hemlock Regeneration and Deer Browsing in the Northern Great Lakes Region: A Re-examination and Model Simulation. Conservation Biology 7(4): 889-900.

Monaco T., S. Weller,F. Ashton. 2002. Weed Science: Principles and Practices. New York, New York: John Wiley \& Sons, Inc. 671p.

Mooney, H.A. and R.J. Hobbs. 2000. Invasive species in a changing world. Washington, D.C.: Island Press. 457 p.

Mooney, H.A., L.E. Neville, P.J. Schei, J.K. Waage, R.N. Mack, J.A. McNeely, eds. 2005. Invasive Alien Speices: A New Synthesis. Washington, D.C.: Island Press. 368 p.

Moore, P.D. 1971. Computer analysis of sand dune vegetation in Norfolk, England, and its implications for conservation. Vegetation 23:3 23-338.

Morrison, R.G. and G.A. Yarranton. 1973. Diversity, richness, and evenness during a primary sand dune succession at Grand Bend, Ontario. The Canadian Journal of Botany. 51: 2401-2411.

Muenscher, W. 1955. Weeds. 2nd ed. MacMillan, NY.

Munz, P.A. and D.D. Keck. 1973. A California flora and supplement. Berkeley, California: University of California Press.

Myers, J.H., and D.R. Bazely. 2003. Ecology and Control of Introduced Plants. University Press: Cambridge. 313 pp.

Myers, N. 1997. Global biodiversity II: losses and threats. Pp. 123-158 in G.K. Meffe and C.R. Carroll, eds. Principles of Conservation Biology, $2^{\text {nd }}$ edition. Sunderland, Massachusetts: Sinauer. 
National Invasive Species Council. 2001. Meeting the invasive species challenge: national invasive species management plan. Washington, DC: US Government. 89 p.

National Park Conservation Association. 2007. State of the Parks: Pictured Rocks National Lakeshore. Pp 6-24.

National Park Service. 1988. Management Policies Washington, D.C. US Government Printing Office.

National Park Service. 2006. Management Policies 2006. Washington, D.C. US Government Printing Office.

National Park Service. 2009. Decreasing effectiveness of protected areas due to increasing development in the surroundings of U.S. National Park Service holdings after park establishments. Natural Resource Technical Report 178. 20 p.

National Park Service. 2010. Nonnative Species of Pictured Rocks National Lakeshore. 2010. National Park Service Website. Accessed: April 2010.

National Park Service. 2010. NPS Overview. Pamphlet.

National Park Service. 2011. Natural features and ecosystems of Pictured Rocks National Lakeshore. http://www.nps.gov/piro. Accessed: March 2011.

National Park Service. 2011a. U.S. National Park Service. www.nps.gov. Accessed: April 2011.

National Park Service. 2011b. Pictured Rocks National Lakeshore. www.nps.gov/piro. Accessed March 2011.

National Parks Conservation Association. 2008. National Parks in Michgan. http://www.npca.org/nationalpriority/pdf/MI-FS.pdf. Accessed: April 2011.

National Research Council. 2002. Predicting invasions of nonindigenous plants and plant pests. Washington D.C.: National Academy Press.

Nazzaro, R.M. 2006. Major operations funding trends and how selected park units responded to those trends for the fiscal years 2001 through 2005. Statement For The Record: National Resources and Environment. US Government Accountability Office. 26 p.

New Mexico Department of Agriculture. 2006. New Mexico Territorial Laws: Plant Protection Act. Chapter 76, Article 5: Insect Pests and Plant Diseases.

Nilsson, M.C., and D.A. Wardle. 2005. Understory vegetation as a forest ecosystem driver: evidence from the northern Swedish boreal forest. Frontiers in Ecology and the Environment 3(8): 421-428.

Nuzzo, V.A. 1999. Invasion pattern of the herb garlic mustard (Alliaria petiolata) in high quality forests. Biological Invasions 1:169-179. 
Olson, J.S. 1958. Lake Michigan dune development 2: plants as agents and tools in geomorphology. Journal of Geology 66: 345-351.

Orians, G.H. and R.T. Paine. 1983. Convergent evolution at the community level. Pp 431458 in D.J. Futuyma and M. Slatkin, eds. Coevolution. Sinauer, Sunderland, Massachusetts.

Ortega, Y.K. and D.E. Pearson. 2005. Weak vs. strong invaders of natural plant communities: assessing invasibility and impact. Ecological Applications 15(2): 651-661

Parker, I.M., D. Simberloff, W.M. Lonsdale, K. Goodell, M. Wonham, P.M. Kareiva, M.H. Williamson, B. Von Holle, P.B. Moyle, J.E. Byers, and L. Goldwasser. 1999. Impact: toward a framework for understanding the ecological effects of invaders. Biological Invasions. 1:3-19.

Pausas, J.G., and M.P. Austin. 2001. Patterns of plant species richness in relation to different environments: an appraisal. Journal of Vegetation Science 12: 153-166.

Petersen, G. 1986. Pictured Rocks National Lakeshore: an American first. Pp. 251-253 in C. Symon, ed. Alger County: A Centennial History, 1885-1985. Alger County Historical Society, Munising, Michigan.

Pictured Rocks National Lakeshore. Grand Sable Dunes Research Natural Area. 2007. National Park Service. http://www.nps.gov/piro/naturescience/upload/. Accessed: April 2011.

Pimental, D., R. Zuniga, and D. Morrison. 2005. Update on the environmental and economic costs associated with alien-invasive species in the United States. Ecological Economics 52(3): 273-288.

Pimentel, D., L. Lach, R. Zuniga, and D. Morrison. 1999. Environmental and economic costs associated with non-indigenous species in the United States. Bioscience 50:53-65.

Pyke, D.A. and S.T.Knick. 2003. Plant invaders, global change and landscape restoration. Pp. 278-288 in N. Allsopp, A.R. Palmer, S.J. Milton, K.P. Kirkman, G.I.H. Kerley, and D.R. Brown, eds. Proceedings of the VII International Rangelands Congress. International Rangeland Congress, Durban, South Africa.

Pyšek, P., D.M. Richardson, and M. Williamson. 2004. Predicting and explaining plant invasions through analysis of source area floras: some critical considerations. Diversity and Distributions 10:179-187.

Pyšek, P., K. Prach, and P. Smilauer. 1995. Relating invasions success to plant traits. An analysis of the Czech alien flora. Pp. 39-6o in P. Pysek, K. Prach, M. Rejmanek, and M. Wade, eds. Plant Invasions: General Aspects and Special Problems, Academic Press Publishing, Amsterdam. Pp. 39-60.

Radosevich, S.R., J.S. Holt, C.M. Ghersa. 2007. Ecology of Weeds and Invasive Plants. Hoboken, New Jersey: John Wiley \& Sons, Inc.. 454p. 
Randall, J.M. 1997. Defining weeds of natural areas. Pp. 18-25 in J.O. Luken and J.W. Thieret, eds. Assessment and Management of Plant Invasions. New York: Springer-Verlag.

Randerson, J.T., H. Liu, M.G. Flanner, S.D. Chambers, Y. Jin, P.G. Hess, G. Pfister, M.C. Mack, K.K. Treseder, L.R. Welp, F.S. Chapin, J.W. Harden, M.L. Goulden, E. Lyons, J.C. Neff, E.A.G. Schuur, and C.S. Zender. 2006. The impact of boreal forest fire on climate warming. Science 314: 1130-1131.

Read, R.H. 1975. Vascular plants of Pictured Rocks National Lakeshore, Alger County, Michigan. The Michigan Botanist 14(1): 3-43.

Reaser, J.K., B.B. Yeager, P.R. Phifer, A.K. Hancock, and A.T. Gutierrez. 2003. Environmental diplomacy and the global movement of invasive alien species: a US perspective. Pp. 362-381 in G.M. Ruiz and J.T. Carlton, eds. Invasive Species: Vectors and Management Strategies. Washington, D.C.: Island Press.

Regan, S. 2011. The most visited National Parks could be self sufficient. High Country News January 20, 2011.

Regniere, J. and B. Bentz. 2009. Pp 63-64 in K.A. McManus and K.W. Gottschalk, eds. Proceedings of the 19th U.S. Department of Agriculture interagency research forum on invasive species 2008; 2008 January 8-11; Annapolis, MD. Gen. Tech. Rep. NRS-P-36. Newtown Square, PA: U.S. Department of Agriculture, Forest Service, Northern Research Station.

Reichard, S.E., and C.W. Hamilton. 1997. Prevention of invasive plant introductions on national and local levels. Pp. 215-240 in J.O. Luken and J.W. Thieret, eds. Assessment and Management of Plant Invasions. Springer, New York.

Rejmánek, M. 2000. Invasive plants: Approaches and predictions. Australian Ecology 25:497-506.

Rejmánek, M. 2000. Invasive plants: Approaches and predictions. Australian Ecology 25:497-506.

Repanshek, K. 2010. Entrance fees generate hundreds of millions of dollars a year for National Park Service. National Parks Traveler February 2010.

Repanshek, K. 2011. Congress slashes \$101 million from National Park Service budget. National Parks Traveler March 2011.

Reynolds, K.M. 1999. EMDS Users Guide (version 2.0): Knowledge-based decision support for ecological assessment. General Technology Report PNW-GTR-470. Portland, OR: USDA Forest Service, Pacific Northwest Station. 63 p.

Ricciardi, A., W.W.M. Steiner, R.N. Mack, and D. Simberloff. 200o. Towards a global information system for invasive species. BioScience 50: 239-244. 
Rice, P.M, D.J. Bedunah, and C.E. Carlson. 1992. Plant community diversity after herbicide control of spotted knapweed. U.S Department of Agriculture, Forest Service, Intermountain Forest 460: 1-6.

Rice, P.M., J.C. Toney, D.J. Bendunah, and C.E. Carlson. 1997. Plant community diversity and growth form responses to herbicide applications for control of Centaurea maculosa. Journal of Applied Ecology 34: 1397-1412.

Ridenour, W.M. and R.M. Callway. 2001. The relative importance of allelopathy in interference: the effects of an invasive weed on a native bunchgrass. Oecologia 126(3): 444-450.

Rook, E.J.S. 2002. Equisteum: horsetail. www.rook.org. Accessed: April 2011.

Sala, O.E., F.S. Chapin III, J.J. Armesto, E. Berlow, J. Bloomfield, R. Dirzo, E. HuberSanwald, L.F. Huenneke, R.B. Jackson, A. Kinzig, R. Leemans, D.M. Lodge, H.A. Mooney, M. Oesterheld, N.L. Poff, M.T. Sykes, B.H. Walker, M. Walker, and D.H. Hall. 2000. Global biodiversity scenarios for the year 2100. Science 287: 17701774 .

Sanders, Jack. 2003. The Secrets of Wildflowers: A Delightful Feast of Little-Known Facts, Folklore, and History. Globe Pequot.

Schnase, J.L. 2005. Invasive Species: An emerging science application for geospatial information. Pp. xiii-xviii in P. Agouris and A. Croitoru, eds. Next Generation Geospatial Information: From Digital Image Analysis to Spatio-temporal Databases. London: Taylor and Francis Group.

Sharma, S.D. and M. Singh. 2001. Susceptibility of Florida candler fine soil to herbicide leaching. Bulletin of Environmental Contamination and Toxicology 67: 594-60o.

Shartell, L.M. 2007. Risk assessment for invasive exotic plants using predictive modeling. M.S. Thesis. Houghton, Michigan: Michigan Technological University.

Shartell, L.M., L.M. Nagel, A.J. Storer. 2011. Multi-criteria risk model for garlic mustard (Alliaria petiolata) in Michigan's Upper Peninsula. American Midland Naturalist 165:116-127.

Sheley, R. L., J. S. Jacobs, and M. F. Carpinelli. 1998. Distribution, biology, and management of diffuse knapweed (Centaurea diffusa) and spotted knapweed (Centaurea maculosa). Weed Technology 12:353-362.

Sheley, R.L. and J.S. Jacobs. 1997. "Acceptable" levels of spotted knapweed (Centaurea maculosa) control. Weed Technology 11: 363-368.

Sheley, R.L., J.S. Jacobs, M.F. Carpinelli. 1999. Spotted knapweed. Pp. 350-351 in R.L. Sheley, J.K. Petroff, eds. Biology and management of noxious rangeland weeds. Corvallis: Oregon State University. 
Small, E. 1973. Photosynthetic ecology of normal and variegated Aegopodium podagraria. Canadian Journal of Botany 51: 1589-1592.

Soukup, M. 2005. Invasive Species: Scientists Demand Action on Invasive Species. Invasive Species Management, Program Plan: 2003-2007, NASA, Office of Earth Science, Applications Program, June 6, 2003.

Southern Weed Science Society. 1998. Weeds of the United States and Canada. CDROM. Southern Weed Science Society. Champaign, Illinois.

Statistix. 2003. Statistix® 8 Analytical Software. User's Manual. Tallahassee. 396 p.

Stephens, A.E.A., P.G. Krannitz, and J.H. Myers. 2009. Plant community changes after the reduction of an invasive rangeland weed, diffuse knapweed, Centaurea diffusa. Biological Control 51(1): 140-146.

Stephenson, N.L. 1988. Climatic control of vegetation distribution: the role of the water. The American Naturalist 135(5): 649-670.

Stohlgren, T.J. and J.L. Schnase. 2006. Risk analysis for biological hazards: what we need to know about invasive species. Risk Analysis 23: 163-173.

Stohlgren, T.J., and C.S. Jarnevich. 2009. Risk Assessment of invasive species. Pp. 19-35 in M.N. Clout and P.A. Williams, eds. Invasive Species Management. Oxford University Press, Oxford.

Stohlgren, T.J., D. Barnett, C. Flather, P. Fuller, B. Peterjohn, and J. Kartesz. 2006. Species richness and patterns of invasion in plants, birds, and fishes in the United States. Biological Invasions 8:427-457.

Story, J. 2002. Spotted Knapweed. Pp. 149-157 in Driesche, R. V., B. Blossey, M. Hoddle, S. Lyon, and R. Reardon, eds. Biological Control of Invasive Plants in the Eastern United States. U. S. Department of Agriculture, Forest Service.

Strahler, A.N. and A.H. Strahler. 1978. Modern Physical Geography. New York, New York: Wiley. $656 \mathrm{p}$.

Stubbendieck, J., G.Y. Friisoe, \& M.R. Bolick. 1994. Weeds of Nebraska and the Great Plains. Nebraska Department of Agriculture, Bureau of Plant Industry. Lincoln, Nebraska.

Sturrock, R.N., S.J. Frankel, A.V. Brown, P.E. Hennon, J.T. Kliejunas, K.J. Lewis, J.J. Worrall, and A.J. Woods. 2011. Climate change and forest diseases. Plant Pathology 60: 133-149.

Swearingen, J. 2004. WeedUS: Database of Invasive Plants Affecting Natural Areas in the U.S. http://www.nps.gov/plants/alien. Accessed: March 2011.

Swearingen, J., K. Reshetiloff, B. Slattery, and S. Zwicker. 2002. Plant Invaders of Mid-Atlantic Natural Areas. National Park Service and U.S. Fish \& Wildlife Service, $82 \mathrm{p}$. 
Taylor, N.L. and Smith, R.R. 1981. Red clover Trifolium pratense. Pp. 11-21 in McClure, T.A. and E.S. Lipinsky eds. Handbook of biosolar resources, Vol. II. Resource materials. Boca Raton, FL: CRC Press, Inc.

The New York Botanical Garden illustrated encyclopedia of horticulture. Vol. 1. A-Be. New York: Garland Publishing Inc.

Theoharides, K.A. and J.S. Dukes. 2007. Plant invasion across space and time: factors affecting nonindigenous species success during four stages of invasion. New Phytologist 176:256-273.

Thomas, S.C., C.B. Halpern, D.A. Falk, D.A. Liguori, and K.A. Austin. 1999. Plant diversity in managed forests: understory responses to thinning and fertilization. Ecological Applications 9: 864-879.

Tutin, T. G., V. H. Heywood, N. A. Burges, D. M. Moore, D. H. Valentine, S. M. Walker, and D. A. Webb, eds. 1968. Flora Europaea, Vol. 2. Cambridge University Press, Cambridge.

Underwood, E.C., R. Klinger, and P.E. Moore. 2004. Predicting patterns of non-native plant invasions in Yosemite National Park, California, USA. Diver Distribution 10:447-459.

United States Department of Agriculture, National Resources Conservation Service. 2011. The PLANTS Database National Plant Data Center, Baton Rouge, LA, USA. http://plants.usda.gov. Accessed: March 19, 2011.

United States Department of Agriculture. 2002. Plant Protection and Quarantine: The Plant Protection Act. APHIS Factsheet. http://www.aphis.usda.gov/lpa/ pubs/fsheet_faq_notice/fs_phproact.pdf. Accessed: April 2011.

United States Department of Agriculture. 2011. The PLANTS Database. National Plant Data Center, Baton Rouge, LA, USA. http://plants.usda.gov. Accessed: March 19, 2011.

United States Department of Agriculture. 2011. The PLANTS Database National Plant Data Center, Baton Rouge, LA, USA. http://plants.usda.gov. Accessed: March 19, 2011.

United States Forest Service. 2005. Common burdock. Forest Health Staff, Newtown Square, PA.

United States. Congress. House. Committee on Agriculture. Subcommittee on Department Operations, Nutrition, and Foreign Agriculture. 2000. Plant protection act. U.S. Department of Agriculture, Animal and Plant Health Inspection Service web site:

http://www.aphis.usda.gov/ppq/weeds/PPAText.PDF. Accessed: December 12, 2010. 
Uva, R.H., J.C. Neal, \& J.M. DiTomaso. 1997. Weeds of the Northeast. Ithaca, New York: Cornell University Press.

Van der Valk, A.G. 1974. Environmental factors controlling the distribution of forbs on coastal foredunes in Cape Hatteras National Seashore. Canadian Journal of Botany 52:1 057-1073.

Vasquez, E.A., J.J. James, T.A. Monaco, D.C. Cummings. 2010. Invasive plants on rangelands: a global threat. Rangelands 32(1):3-5.

Vitousek PM. 1990. Biological invasions and ecosystem processes: towards an integration of population biology and ecosystem studies. Oikos 57:7-13

Vitousek, P.M. and L.R. Walker. 1989. Biological invasions by Myrica faya in Hawaii: plants population biology and ecosystem studies. Oikos 57: 7-13.

Vitousek, P.M., C.M. D’Antonio, L.L. Loope, and R. Westbrooks. 1996. Biological invasions as global environmental change. American Scientist 84:468-478.

Vitousek, P.M., C.M. D’Antonio, L.L. Loope, and R. Westbrooks. 1996. Biological invasions as global environmental change. Conservation and Ecosystem Management. Pp 218-228.

Vitousek, P.M., H.A. Mooney, J. Lubchenco, and J.M. Melillo. 1997. Human domination of Earth's ecosystems. Science 277: 494-499.

Voss, E. G. 1985. Michigan Flora. Part II Dicots. Cranbrook Institute of Science and University of Michigan Herbarium.

Walker, L.R. and P.M.Vitousek. 1991. An invader alters germination and growth of a native dominant tree in Hawaii. Ecology 72: 1449-1455.

Walther, G.R., E.Post, P. Convey, A. Menzel, C. Parmesan, T.J.C. Beebee, J.M. Fromentin, O. Hoegh-Guldberg, and F. Bairlein. Ecological responses to recent climate change. Nature 416: 389-395.

Watson, A. K. and A. J. Renney. 1974. The biology of Canadian weeds 6. Centaurea diffusa and C. maculosa. Canadian Journal of Plant Science 54:687-701.

Weir, T.L., H.P. Bais, and J.M. Vivanco. 2003. Intraspecific and interspecific interactions mediated by a phytotoxin, (-)-catechin, secreted by the roots of Centaurea maculosa (spotted knapweed). Journal of Chemical Ecology 29(11) 2397-2412.

Welk, E., K. Schubert, and M. H. Hoffmann. 2002. Present and potential distribution of invasive garlic mustard (Alliaria petiolata) in North America. Divers Distribution 8:219-233.

Westbrooks, R.G., W.P. Gregg, and R.E. Eplee. 2001. My view. Weed Science 49: 303304. 
Whitson, T.D., eds. 1996. Weeds of the West. Laramie, Wyoming: University of Wyoming. $628 \mathrm{p}$.

Wilcove, D.S., D. Rothstein, J. Bubow, A. Phillips, and E. Losos. 1998. Quantifying threats to imperiled species in the United States. BioScience 48(8): 607-615.

Williamson, M .and A. Fitter, A. 1996. The characters of successful invaders. Biological Conservation 78: 163-170.

Willis, A.J., B.F. Folkes, J.F. Hope-Simpson, and E.W. Yemm. 1959. Braunton Burrows: the dune system at its vegetation. Ecology 47:1-24,249-288.

Wilsey, B.J. 2005. Importance of species replication in understanding plant invasions into North American grasslands. Pp. 61-75 in O. Inderjit, ed. Invasive Plants: Ecological and Agricultural Aspects, Birkhauser Verlag, Switzerland.

Winks, R.W. 1997. The National Park Service Act of 1916: "A Contradictory Mandate?" Denver University Library Review. 575 p.

Wittenberg, R. and M.J.W. Cock. 2001. Invasive Alien Species: A Toolkit for Best Prevention and Management Practices. Oxon: CAB International. 